


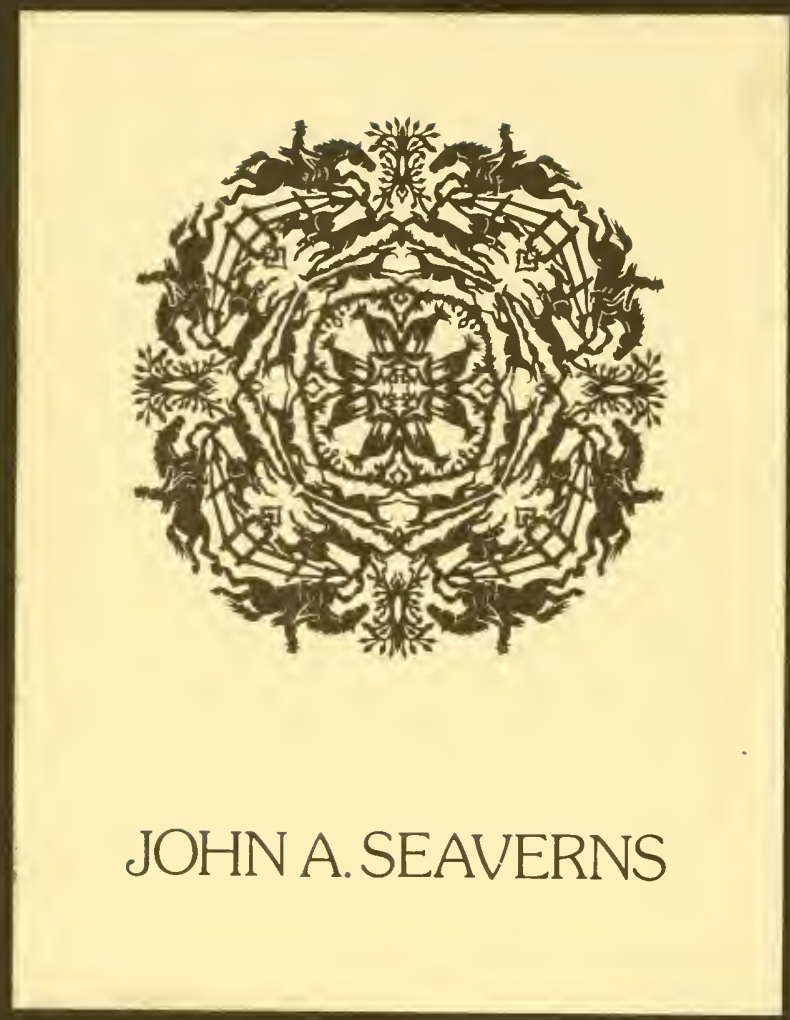



v

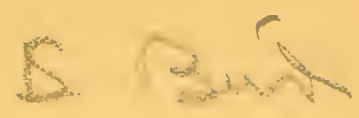

ind and

c u eg of ale

$1912 \%$

Webster Family Library of Veterinary Medicine Cummings School of Veterinary Medicine at Tufts University 200 Westboro Road North Grafton, MiA 01536 


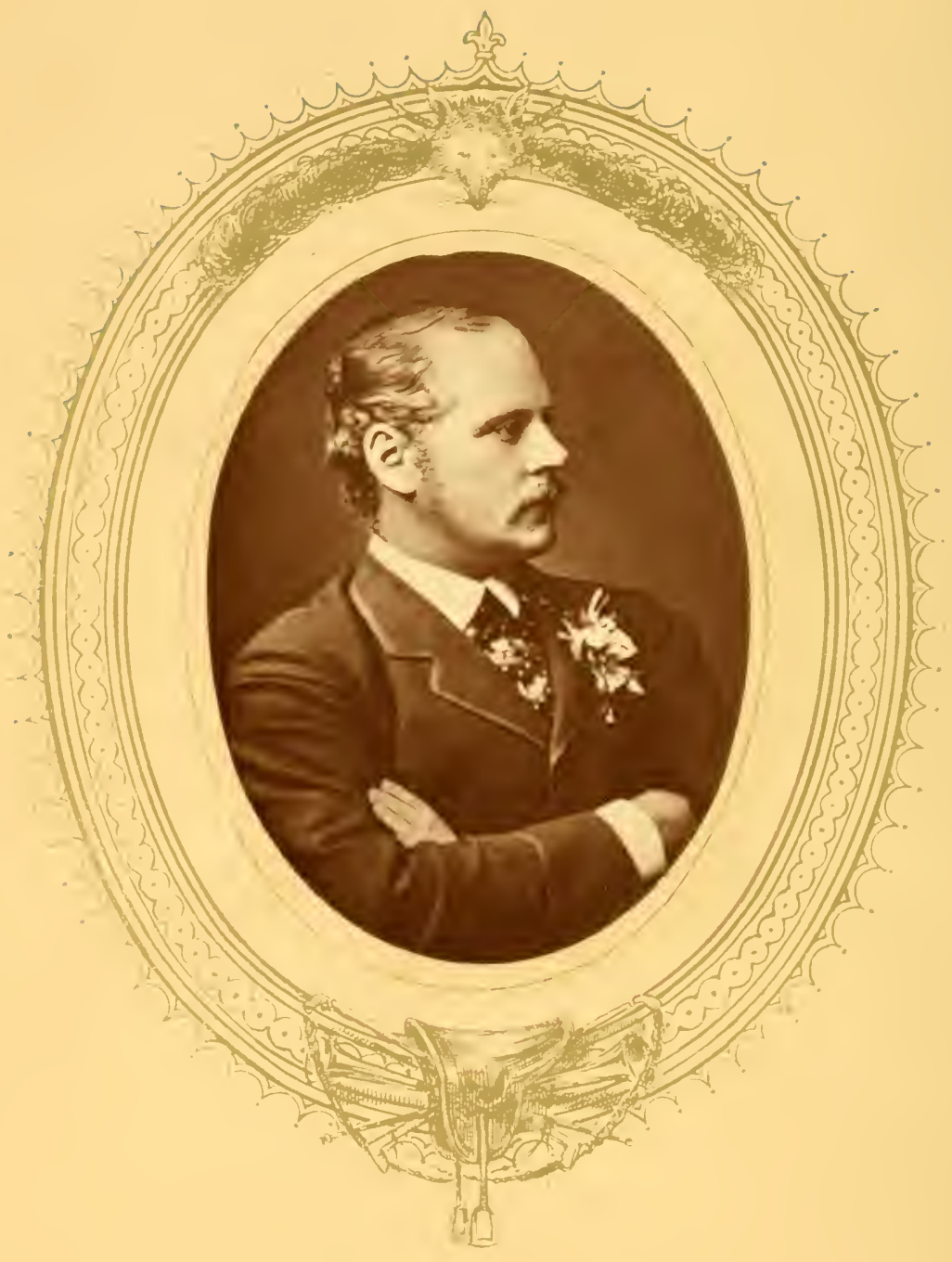




\section{IRISH SPORT}

AND

\section{S POR T S M E N.}

B. M. FITZPATRICK.

$D U B L I N$ :

M. H. GILL \& SON, 50 UPPER SACKVILLE-ST. 1878 . 


\section{Se $\quad 1^{-1}$}

$S K$

is

$-$

$\because+1$

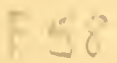

1878

[AIA, RIGHTS RESERYED.] 
I DEDICATE, BY PERMISSION, THESK

SKETCHES OF IRISH SPORT AND SPORTSMEN, TO THE

\section{Anarquis and fltarchiourss of Waterford, \\ AND IN DOING SO,}

I FEEL I HAVE TAKEN A STEP TO ENSURE THE SUCCESS OF MY BOOK; FIRSTLY, ON ACCOUNT OF TIIE PLACE

WHICH THE HOUSE OF BERESFORD FIILS IN IRISH SPORTSMEN'S HEARTS, AND THEN,

THAT ON THE OPENING PAGE MAY BE INSCRIBED THE NAMIES OF THE TWO GREAT FAMILIES

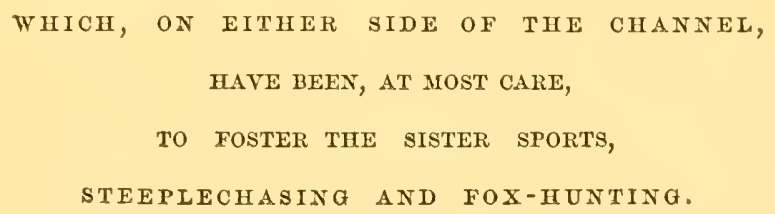

THE AUTHOR. 



\section{P REFA.CE.}

75. $N$ compiling this book I have been forced to confront many difficulties. Like all who venture on novel essays I found the most formidable obstacle was the one I least expected. Prior to entering on the task of placing before the public a reliable statement such as I proposed to produce, I had to look out for authentic records. The kindness with which many Masters of Hounds and others have seconded my endeavours was quite remarkable. I have a very srateful duty to fulfil when I acknowledge it in the most marked way; and though, for obvious reasons, I do not particularise by name my volunteers and assistants, I am not the less grateful to them. TWen I conceived the scheme of this publication, I thought that written stories of interesting information of the doings of Irish Sportsmen, long since dead, their horses and their hounds, might be dug up by industrious research. In this I was mistaken, and the ample authenticated written evidences I had quite confidently 
expected, turned out to be very meagre. Those so generously supplied me, were on the whole, quite reliable, though occasionally in opposition to traditions which a minute inquiry oftimes very curiously supported. The knowledge of my informants seldom extended beyond, sometimes not to, the generation which preceded them. On consideration, I cannot but think that the discovery which I made as to the paucity of our annals of the subjects I treat of, is a great justification for my endeavouring to treat of them at all, for I may, perhaps, flatter myself that I can, in some sense, supply for my successors the want which, in my own instance, I had much trouble in providing. My task, as far as it extended to Racing, was easier than that which touched Hunting, as the "Calendars" supplied a sure foundation for my work. Their existence, too, made it less incumbent on me to be as diffuse as I am in my memoranda of the chase. In advance, I have to ask indulgence for the shortcomings of these pages, of which no one can be more conscious than I am. Had others written long ago what they knew or heard, it would have been easy for me to have presented some old wine in a new bottle. Their neglect to do so is, however, sufficient "raison d'etre" for my attempting to remedy their default. In conclusion I have only to once more acknowledge the sympathetic assistance which has been graciously given to me by a crowd of witnesses, 
so large as to confirm my anticipation that the story $I$ present to my readers is addressed to a very numerous class, whose merits in no measure fall short of those of bygone "Irish SPORT and SPORtsmin."

BERNARD M. J. FITZPATRICK.

Fohnstoze'n House, Straffan, Co. Kildare.

C'hristmas, 1877. 



\section{CONTENTS.}

CHAP.

I. The Kildare Hounds . $\quad$. $\quad$. $\quad 13$

II. The Curraghmore $\quad$. $\quad$. $\quad$. 45

III. The Ward Union Hounds . . . . 90

IV. The Meath Hounds . . . . . . 105

V. The Louth Hounds . . . . . III

VI. En Route to Galway . . . . . 121

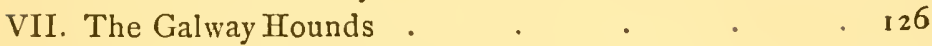

VIII. The Carlow and Island Hunt Hounds . . 148

IX. The Tipperary Hounds . . . . $\quad$ I53

X. The Westmeath Hounds . . . $\quad$ I59

XI. The Cashelmore Hounds . . . . 167

XII. The Wexford Hounds . . . . 180

XIII. The Limerick Foxhounds . • . $\quad 185$

XIV. Hunting in Roscommon . • • 204

XV. The South Union, United Hunt, and Muskerry Hounds 2 I 2

XVI. The Ormond and King's County Hounds • 224

XVII. The Queen's County Hounds • • • 234

XVIII. The Limerick Staghounds, Duhallow and Lisnagon

$\begin{array}{ccccc}\text { Hounds } & \text { • } & & & \\ \text { XIX. The Kilkenny Hounds } & \text { • } & \text { • } & \text {. } & \text { • } 249\end{array}$

List of Harriers in Ireland . . . . 268

XX. Henry, third Marquis of Waterford • • • 273

XXI. The Corinthian Cup Picture, Punchestown, I854 • 300

XXII. The Corinthian Cup Picture-(continut) • • 315

XXIII. The Corinthian Cup Picture-(continued) • • 319

XXIV. Mr. John Hubert Moore . • • • 336

XXV. Mr. Allen M'Donogh . . . . 343 

PART I. 



\section{R I S H S POR T}

AsD

\section{S PORTS M.EN.}

\section{CHAPTER I.}

THE KILDARE HOUNDS.

"HE "Killing” Kildare premicr pack, \&c., are phrases which hunting men are used to apply as naturally as young men and maidens, the slaves of Cupid, do "Duck," "Dear," or "Darling." And well these hounds merit the flattering designation: assuredly, taking this sea-girth isle as the boundary, the pack is not inferior to any. It may well be compared with any in the kingdom; and the country over which they hunt is, in a fox-hunting sense, the "cream" of all Ireland.

The first master of the "Kildares" was Squire Connolly, of Castletown, a very eccentric, jolly soul; he was a thorough sportsman of the good old school, a notorious bon vivant. He kept open house, and on hunting days all who participated in the pleasures of the chase with him were expected to dine in Castle- 
town; none were invited, all were welcome when they came; in truth, it may be said, that " though he feasted all the great he ne'er forgot the small."

Some years before Squire Connolly's death, the pack was kept at Bishopscourt, though he was the recognised master; when he died in 1804, Sir Fenton Aylmer succeeded him, and kept the hounds for a year or two; and then Mr. Arthur Henry took them, and kept them till I810, when Sir Fenton Aylmer resumed the mastership.

He had a very famous huntsman, Jack Grennon, gifted with a grand voice; a first-rate rider, but like all of us, he had his faults, and one of them was being too hasty to please the hunting men of his time, though, I dare say, his manner would be considered not unbecoming in these more demo. cratic days. The whips, Will Mathews and his son, were men who subsequently acquired a great reputation.

In $18 \mathrm{I} 3$, an accident occurred which destroyed the best hounds in the kennel. The meet was at Tipper cross-roads, near Naas; a fox was found in Forenaughts, and a grand run ensued to Poulaphouca, beloved of pic-nicers. Just near the spot where the bridge now stands Reynard plunged into the rushing torrent, thirteen couple of the pack followed suit, there was a strong "freshet" in the Liffey at the time, and they were all drowned.

In 1814 , Sir John Kennedy became master: he certainly may be called the "father of the hunt;" his popularity was as widespread as it was deserved; a more enthusiastic worshipper never paid homage at Diana's shrine, nor a more genuine sportsman ever wore at his 
saddle bow that emblem of mastership-the silver horn. I may say with truth,

"Tis" now more than sixty years since he assumed the post

Of master to the Kildare hounds, when he was needed most;

And, though nigh single-handed, he proved himself a host,

In making them what they are now-in truth, the country's boast."

I have gained much information from a very interesting MS. from the Johnstown-Kennedy library; and this will be an appropriate place for me to offer my very sincere thanks to Sir Edward Kennedy for his kindness in allowing me to inspect them, and to assure my readers that, without that kind indulgence, they, and I, must have remained in ignorance of what I consider the most important epoch in the formation of the Kildare hounds. Sir John Kennedy kept a diary of not only every run, but what is an even more pleasant reminiscence, the names of those who shared the sport with him. It would be well if the gentlemen of the present day followed his example in this respect: the records would be read with interest by a "generation yet unborn." One likes to see the names of parents, relatives, or friends recorded in such old archives-they recall scenes to memory dear. Indeed, it was thinking on this subject that first put the idea into my head of writing this volume. The history of the different packs must of necessity be a matter of dry and simple detail; but sporting readers are not inclined to be critical, so long as they perceive the vi vida vis, the fervidus, afflatus in works such as "Irish Sport and Sportsmen." Such records, I opine, afford pleasure and recreation to many. If it be pleasant to peruse works which revive in our minds past enjoyments, 
shared in when "our lines were cast in pleasant places," 'tis especially so in the evening of our lives, when our sun has almost set, and when we by anticipation feel the chill touch of the "wooden surtout," or hear the final inevitable summons. Though our fate during our struggle in this vale of tears may have been unpropitious, though the links that bound us to the "old house at home," may have been shattered, and the well-knit bonds of friendship which allied us to those most dear may have been severed, memory paints the past with a consoling, though, perhaps fictitious splendour, and any record which aids it is of use. In the manuscripts alluded to I found the names of the first supporters of the Kildare Hunt.

They were, in 1806, Mr. John Farrell ; in I807, Messrs. Robert Archbold, Arthur Henry, Joseph Connolly, and Val. Maher; in 1809, Sir (then Mr.) John Kennedy; in I8II, Sir W. Hunt, and Mr. R. Warburton; in 1812 , Lord William Fitzgerald, Lord Henry Moore (Lord Drogheda's father), and the Duke of Leinster ; in 18 I $_{5}$, Lord Portarlington ; in I $825, \mathrm{Mr}$. Richard More O'Ferrall, and Lord Howth; in 1836 , the brothers John and Robert La Touche.

At a meeting held in Morrisson's Hotel, then called Morrisson's Tavern, on the Ioth of October, I8I4, it appears that Sir John Kennedy offered to take the hounds, provided that the members would guarantee him $£ 500$ per annum, to enable him to defray the expenses of keeping the coverts, paying for fowl, \&c. The offer was gladly accepted.

The baronet was, facile princeps, in every branch of knowledge essential to good mastership, and he spared 
no expense. He used to hunt his hounds five days a fortnight, and the country extended as far as Oakley Park, in Carlow, and Loughcrew, in the county Meath. Of course the custom at that time was to be out at dawn of day. Jigginstown, where the kennels now stand, was a very favourite tryst, and many an ardent sportsman, who now lies "mouldering in the grave," spent hours there on a wild winter's morning seeking shelter beneath the ruins of the unfortunate Earl of Strafford's intended palace, awaiting the return of the "varmint" to these favourite earths.

The men of those days were men of "metal," so to speak, far different, alas! from the not effeminate, though more polished and as ardent sportsmen of to-day.

The habitues of the hunting field, of late years, may have often seen, when standing on the hill which overhangs that magnificent piece of gorse known as Elverstown Covert, John Nolan, a man who has catered to the wants of the fox family-bless their brushes-for years past. Well, his father was earth: warner during Sir John's time, and he frequently received his instructions from him in Johnstown: Kennedy on a winter's evening, walked to Loughcrew, stopped the earths there, and returned to Elverstown, doing the long journey and his business within the twenty-four hours. There were not giants in those days; but there were many men of slender mould made of sterner stuff than those of the present generation.

The Club was very much in debt in 1814 , the sum total of the liabilities having amounted to no less than $f 2,400$. The foxes were more numerous then than now. The runs were generally longer too; the gentry did all 
in their power to preserve foxes. They appear to have managed all the affairs relative to the hunting of the country in the most systematic manner, and the wording of many of the resolutions passed at their meetings would amuse had I space to quote them. For instance, at a meeting held in Naas, during Sir John Kennedy's mastership, we find that the following resolution was passed and forwarded to Mr. Digby of Landenstown :

"We, the undersigned members of the Kildare Hunt Club, have heard with great regret that Mr. Digby's butler has shot a fox, and we hope that Mr. Digby will take such steps as will prevent said butler from again perpetrating a similar crime while in his employment."

At the next meeting the following communication was received from Mr. Digby:

"Mr. Digby has heard with great regret of the offence committed by his butler, and begs to inform the members of the Kildare Hunt Club that he has discharged said butler."

Sir John Kennedy always hunted the hounds himself, and there never was a man who knew better when to cheer or to chide them; he was a first-rate horseman, had a splendid voice; many a fox did his view-hallow " awake from his lair in the morning." He seldom used a horn. The Rev. Robert Burrowes was secretary during his reign; he had a passion for hunting. I have heard a gentleman state that he never knew a more ardent fox-hunter; and, he added, "he spent his days either in the saddle, or on his knees at the earths, going throughout the country." When asked to explain, the answer my informant gave 
was, that when the parson was not riding, he usually spent his time going from one likely fox-refuge to another; and when he came to an earth, or a hole where he suspected one of the "artful dodgers" might be, he used to throw himself on his hands and knees in his anxiety to track him. Many noted hard riders hunted in Kildare at this period, and it was a rare treat to see Sir John on his notable white horse, Gamecock; Robin Aylmer, of Painstown, on his black stallion, Rununculus, a brilliant performer, but very savage brute; Sir Philip Crampton and "Parson" Burrowes, leading the pair over an intricate country. There was a curious character, Sugu by name, one of the Mickey Free type, who used to follow the hounds on foot in those days. One day he happened to be stand ing on the banks of the well-known Laragh river, when, near the end of a great run, the pack crossed the stream; at this time "the good and the true ones" were far in front, the field being scattered like the tail of a comet. The leading two jumped a very wide place, and the first over was Sir John. "More power, yer honour; yer a chip of the real good ould block; may ye live for ever," exclaimed Sugu. The next over was Robin Aylmer. "Bravo Squire; sweet Painstown, and an Irish sky above it; musha the devil himself couldn't 'hould' you." Then came Sir Philip Crampton. "Well done, Dr. Phil; may I never die till you cut a leg o' me," exclaimed the enthusiastic rustic.

The members of the Kildare Hunt Club used not to confine their hunting manœuvres to the home circuit either. They frequently spent a week or so together at a hotel in a good hunting country, and 
during those festive gatherings the fun of the chase was only exceeded by the hilarity of the after dinner time, when the majority of the com. pany were Bacchi plenus before being conveyed to bed. En passant, I may remark that they had a very beautiful service of plate, which was afterwards sold to discharge some of the debts, and this they always brought with them during these excursions. Such was then the custom, and right merry meeting these festive reunions were. About this time the Benson's Club was in existence, and the members used to bring a pack of hounds with them to Castlepollard, county Westmeath, annually, and during a month's sojourn there the fun and dissipation were something wonderful. Colonel Lennox, afterwards Duke of Richmond, a notorious bon vivant, having heard of the bibulous capacity of the members of "Benson's" sent a challenge, which was accepted. The test of endurance between the contending parties was, that after drinking two bottles of brandy, and smoking an ounce of tobacco, with occasional relays of "devilled" kidneys, they, without ever going to bed, should hunt all day, the best "stayer" to win. The colonel distanced all his competitors with the exception of a Mr. O'Rielly. The performance commenced on a Monday; on the Sunday morning following, when he walked into the kitchen, the colonel was amazed to see his opponent dancing with the chambermaid; he at once "threw up the sponge," and, no doubt, spoke truly when he said, "I never met a man before who could drink six nights, hunt six days, and then enjoy an Irish jig with Betty:". 
To connect us, perhaps, with the great past, a club, founded on the lines of the Benson's, still exists and flourishes-The Down Hunt assembles yearly for convivial purposes; and as there are no hounds, and the membership of the very exclusive body entails no qualifications in horsemanship, the memories of old days, when many of the body followed the Lord Charlemont to Dungannon, and the pictures of long since dead members in the quaint uniform of the club, are the only connecting links with the time when sport was its raison d'etre. The election to the privilege of wearing the drab dress coat and gold button, is an honour very eagerly sought by Ulster gentlemen; and the man who emerges unscathed from the annual week's long symposia, will have proved his claim to membership of any convivial body in dear Ireland or elsewhere.

In I 808, field-money was first paid in Kildare, the sum charged being $1 s .8 d$. On the 6th of April,

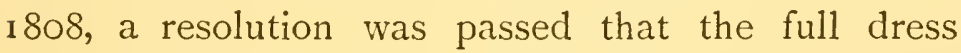
uniform should be, blue coat, buff waistcoat.

It may interest some to know who were the most liberal subscribers to the fund in those days. In 1825 these were-The Duke of Leinster, $\measuredangle 50$; Lord IV. Fitzgerald, $\mathscr{E}_{28} 8$ s. $9 d$.; Robert La Touche, $£ 50 ; H$. Carroll, $£ 50$; Lord Mayo, $£_{20}$; W. H. Carter, $£^{22}$ 15s.; Colonel Loftus, $\ell_{0}$ i 7 7s. $6 d$.; John H. Mayle, and Robert Saunders, $\ell_{22}$ I 5 s.

In $184 \mathrm{I}$, Sir John Kennedy resigned, after a reign of much longer duration than any of his successors have enjoyed. He was succeeded by Mr. John La Touche, of Harristown. His term of office extends over five seasons, during which time his great efforts 
to show sport, and turn out everything in the best style were eminently successful. He was a very general favourite, and he, and his brothers, Robert and William, were brilliant horsemen. Mr. La Touche, who is an exceptionally good judge of horses, kept a splendid stud of hunters. He usually drove a drag, perfect in its appointments, to the different meets; few more expert "whips" ever sat on a coach-box. He was well versed in stud lore too, and no man living took greater interest in the canine alliances than his brother William. "Jem" Byrne, afterwards "master of the horse" to Captain Sheddon, who has these many years been a consistent and liberal supporter of the Kildares, who had been for many seasons whip to Sir John Kennedy, hunted the hounds for some time after Mr. La Touche took them; subsequently Mr. La Touche carried the horn himself. The next master was the late Mr. David O'Connor Henchy, of Stonebrook, Ballymore-Eustace; he took office in 1846 . He, too, was a great man in the saddle, and an ardent supporter of the turf and of hunting. His own colours, blue and pink, were sometimes worn; but old "Dame Fortune," like other dames, is fickle, and she was not generous in her recognitions of his high claims to favourable treatment at her hands. He shared the racing fortunes for a short time of his brother-in-law, Sir Thomas Burke, who was one of the "pillars" of the Irish turf. He discharged the onerous duties appertaining to the post of master of foxhounds to the entire satisfaction of all interested in the welfare of the "Kildares." Although he had them during that awful period when gaunt famine desolated our 
country, and escorted death through the lonely plains of our land,-I need scarcely say that he had much difficulty in hunting the country during such a trying time- " the sinews of war," the coin of the realm, were sadly wanting, and the exchequer of the Club was in a lamentable state of deficiency. During the year I 847 he was the uncomplaining loser of $£ 475$. He resigned at the close of the season $1847-8$. Strange to say, the members of the Hunt do not appear to have appreciated his strenuous exertions in a good cause. One would think that they would have presented him with a testimonial, for no man more fully deserved a substantial recognition from the lovers of the "noble science" than he did. Soon after his retirement, however, the people of the county testified their kindly regard for him, and confidence in his worth by returning him as their representative in the House of Commons, although he was opposed in the election by one of the most esteemed men of Kildare. He sat for the county from $I_{5}{ }_{2}$ till 1859 , and died on the ist of December, I876. I should have stated that Sir Edward Kennedy was appointed Hon. Secretary to the Hunt Club in 1844 . Mr. La Touche received $£ 300$ per annum for keeping the horses, hounds, \&c., and about double the sum was given to Sir Edward to defray the expenses of keeping the coverts, paying for reynard's depredation on fowlsin a word, for keeping the country. Mr. J. Kilbee was secretary before Sir Edward took the post. $\mathrm{He}$ and all his predecessors were paid officials.

The successor of Mr. O'Connor Henchy, was Mr. William Kennedy, Sir John's second son; he was at that time, a "crack" Corinthian rider; and in the 
hunting-field, then, as now, his motto would seem to be that of the old maid relative to her female domestics, "no followers allowed." When the scent and run are good, he may often be seen first amongst the leading lot.

During the "forties" and "fifties" there were many great men to hounds to be met with in this Irish shire. Besides those whose names I have mentioned as being such, I may add Mr. Carroll, of Ballinure; many wonderful tales are told of his marvellous feats on his great black stallion; he was, indeed, a veritable "bruiser," and so were Major "Dick" Magennis, and Mr. Carter, of Castlemartin, both one armed men. The major lost his arm at the battle of Albuera: a writer of verses to the distinguished members of the Oakley Hunt, A.D. I 843, which appeared in "Bailey's" Magazine, wrote of him:

“ Bounding o'er brook with gallant air, Magennis comes in view,

Who rides with single arm to hounds Better than most with two."

The late Lord Cloncurry (then Hon. E. Lawless) was a "first flight" man too. Mr. Edward J. Beauman, who resides at Furness, Naas, may be put down in the same class, as well as Mr. P. Lattin Mansfield, of Morristown Lattin, who now comes out very seldom ; and the late Mr. T. De Burgh, of Oldtown, Naas, deserves mention.

A very good huntsman served under Mr. O'Connor Henchy,-Backhouse, an Englishman, and a great rider. Mr. Kennedy hunted the hounds himself, with Stephen Goodall as first whip: Mr. Kennedy was replaced in 1852 by a very worthy sportsman, John 
Henry Scott, third Earl of Clonmel, who was distinguished for his bon hommie and sportsman-like qualities. He never was a very good horseman, though a most ardent huntsman, was beloved by his tenantry, and possessed a character of such patent amiability that persons of all creeds and classes united to make his reign as M. F. H. one of the most eventful ever enjoyed.

He was succeeded, in 1857 , by the late Lord Mayo (then Lord Naas), who was assisted by one of the best huntsmen that ever carried a horn-Stephen Goodall. Stephen had been in office under the Bishopcourt dynasty, and he enjoyed and deserved a fame in Irish annals such as was only paralleled by his brother Will, then of the Belvoir. He showed grand sport, was a keen sportsman, and by procuring drafts from the Belvoir, Foljambe, and Brocklesly blood, improved the pack a good deal. During his time, too, the country was benefitted by the addition of several coverts-they were mostly natural pieces of gorse-and the members of the Hunt Club subscribed to have them enclosed, \&c. His lordship rode fully seventeen stone, yet he often held a good place amongst the leading brigade throughout a good run-of course he was always well mounted, and was a first-rate judge in equine matters; indeed, I may say of stock of every description. When Lord Mayo accepted the mastership the funds were very deficient. At a meeting held on the 4 th of May, 1857 , it was found the estimated expenditure for the coming season, $£_{1}, 650$, would far exceed the money in hand, as there was only a sum of $£ 900$ from subscriptions, and $£ 250$ of field-money. Before 
the end of Lord Mayo's first season the funds had risen to $£ \mathbf{I}, 45^{\circ}$, and the field-money to $£ 35^{\circ}$. When he resigned the field-money was nearly doub?ed, and the subscriptions increased so considerable as to warrant the expenditure being fixed at $f 1,900$ a year. The "Kildares" had two extraordinary runs during Lord Mayo's reign-one was from Laragh, in November, 1859. The fox was killed, after a run of over two hours' duration, near Swainstown, in the county Meath : the distance from point to point was nineteen miles by the ordnance map. Goodall was the only man who rode over the last fence; he stated that he never rode over such a grand country, and that for the last hour he never crossed over a ploughed field. The second memorable run was from Baltiboys, near Ballymore-Eustace, to Mr. Walshe's, of Belgard, six miles from Dublin, where the hounds were left hunting their fox in the dark. They must have gone over twenty miles. Lord Mayo took a great interest in the Irish turf, and did more than a little for its welfare. He raced a few horses, but I think his yellow and crimson jacket was borne but once successfully, that was when, in I862, he won the Kildare Hunt Cup with Hornpipe. The last time it was seen on a racecourse was at the Curragh October meeting I 868, when he raced a filly called Purity for a Selling Stakes, which was won by Kate Kearney. Purity fell, and gave her pilot a bad fall. Jem Doucie rode her, and I think I am correct in stating that this was his maiden race.

Lord Mayo was the founder of the Palmerstown Association, and had he been spared, it would, probably, be in a flourishing condition now ; and during 
its existence, it tended to improve the breed of thoroughbred horses in Ireland very materially, and many good ones first saw the light within the Palmerstown paddocks. His lordship's character as a statesman is so well known that I need not dwell on his wonderful ability. He sat for Kildare from I 847 till 1852 ; for Coleraine, from ' $52-$ ' 57 ; and subsequently for Cockermouth, a borough in the patronage of Lord Leconfield, whose daughter he married in $\mathbf{1} 848$. He was Chief Secretary for Ireland

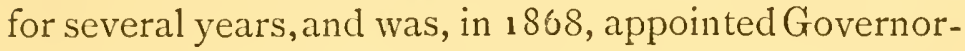
General of India, and there, in 1872, he was basely assassinated in his joth year. Although his politics were not those shared by the great majority of his countrymen, Lord Mayo had won and deserved the respect of all classes. His manly, straightforward conduct even to his opponents, won the regard of the bitterest of them; and a certain strong-handed policy, very intelligible, even if directed in unpopular channels, never alienated the affections of the many ad. mirers who, knowing Lord Mayo, were forced to be proud of him as an Irishman and sportsman.

His funeral was one of the most splendid pageants of its kind ever witnessed in this country. The Irish people bore willingly their testimony as to the high opinion they entertained of him; and while I am penning those lines artificers are engaged in Palmerstown building a magnificent mansion, raised by the subscriptions of his countrymen. It will be a fitting monument erected to the memory of a great man. He might have been interred in Westminster Abbey, but his Lordship often expressed a wish "that his remains should be laid at home." 
Those who have passed along the high road from Dublin to Naas, must have noticed Johnstown, a charming neat little hamlet, which seems to nestle under the protecting woods of Palmerstown. It seems but yesterday since his lordship, on the beauideal of a weight-carrier, dressed in his ample pink, with the master's hunting horn at his saddle-tree, surrounded by those canine pets whose music he loved so well, stood in the village at the entrance gate to his demesne, and received-on November's first Tursday-the cordial greeting of brave men and fair ladies, come to participate in the pleasures of the chase with him; and now, a few yards further down, "The Mayo Arms" stands, and opposite to it a little grave-yard; in its centre a ruin, clad with clinging ivy; and within its walls a plain Wicklow granite cross marks the grave of the late Lord Mayo.

He was succeeded as master in I 862, by Baron de Robeck, of Gowran-Grange, Naas. It is no exaggeration to say that few better men to hounds ever rode over the plains of Kildare. Hogg was promoted to be huntsman by Lord Mayo, and a great mistake it was on his lordship's part, for a worse huntsman never handled hounds in the country; and I believe the only hounds he hunted after he left Kildare were the hounds at Rome, so his services were not appreciated in England or Ireland; he was huntsman for a short time to the Baron, and then Richard Lyons, who had been first whip, was promoted to be huntsman.

The sport shown by Baron de Robeck during his regime will bear comparison with any of his predecessors; and on his retiring after six years' service, hunting men of all classes in the county subscribed 
a slight token of their gratefulness to him for the satisfaction he gave during his term of office. The next master was Sir Edward Kennedy, Bart. The family is one of the oldest in Leinster, and Sir Edward's ancestors were all noted for their devotion to the sports of the field. As I stated before, his father may be called the founder of the Kildare Hunt Club ; and that his father and grandfather kept hounds, is proved by the fact that both bequeathed a legacy to their huntsman in their last will and testament. There are now some old silver buttons in Johnstown-Kennedy which adorned the costume of those huntsmen; and it is evident that they used to hunt foxes, as the figure of a fox and the words "Johnstown-Kennedy Hunt" are engraved on them.

Sir Edward Kennedy, or to be more exact, Charles Edward Bayly Kennedy (Unit. Kigd., I 838), eldest son of Sir John, first Bart., and his wife, Maria, daughter of Edward Beauman, of Rutland-square, Dublin, born on the $13^{\text {th }}$ of February, 1820 , succeeded his father, I 3 th of October, 1848, and was educated at Eton. That he had inherited the ardent love for the " noble science," which appears to have been trans. mitted from sire to son through many generations of Kennedys, soon became apparent. Indeed it was only natural instinct that led him to embrace the sport so keenly, and study venery in its minutest details. He was only 23 years of age, when he became Honorary Secretary to the Kildare Hunt Club. He discharged the duties which devolved upon him as such in the most satisfactory manner; and to do so required a great deal of tact, a knowledge of the country, and, above all, popularity amongst all classes. The latter enviable 
distinction appears to be a sort of heir-loom to the family; and it has become a kind of proverb in Kildare that "there never was a bad Kennedy." Sir Edward is a most indulgent landlord, and that he understands agriculture, and takes an interest in it is proved by the fact that Johnstown-Kennedy presents all the appearances of a "model farm." Being a sportsman "to the manner born," and residing in a county where the chimes of the paddock-hill are heard almost as frequently as the melody of hound music, it is not surprising that he entertained a penchant for the sport happily styled national; and we find his colours, "green, pink sleeves, and black cap," registered in Mr. Justice Hunter's "Calendar" of 1853 , for the first time; but they had been "sported" a few times previous to that year. In ' 53 the first Corinthian Cup was run for in Punchestown, and Sir Edward rode a mare of his own for it, named Concetta. She was a small hunter, and the Baronet was "chaffed" a good deal as to his chances of success, and he consequently backed the mare for a good deal of money, to beat more than would beat her; and she did, for she finished fourth out of eighteen runners.

At the Curragh June meeting that same year he rode his own horse, Collier, for the Corinthians. There was a long price to be had about him, as Mr. Wm. Kennedy's Brother to Russborough, afterwards called Cruisk, ridden by owner, and Lord Waterford's April Fool, ridden by Major Bell, were backed for a great deal of money. The first heat terminated in a half. length victory for April Fool, after a great finish with Collier, but Brother to Russborough won the second and final heat easily. 
The last time Sir Edward rode was for a Corinthians at theCurragh September meeting following. It was a great race, and came off on the same afternoon that Tom, ridden by J. Osborne, defeated Ariadne, Bacchus, Gamekeeper, Junanita, Purez, and other good horses for the Angleseys Sir Edward Kennedy rode May-day, a filly by Harkaway, the property of Mr. Orford, of Suncroft ; his opponents were Lord Waterford's Lambay (Major Bell), Mr. WW. Kennedy's Nee-shay-wooshin (I wish there was a nag of that name now, what a jawbreaker it would be to the book-makers) (owner), Mr. J. Balfe's Royalty (Major St. John), and Mr. Courtenay's Gay Lad (Capt. Pretyman). Odds were laid on Lambay for the first heat, but Neeshay-wooshin won easily. In the next heat he was better off, and a tremendous "set-to" between Lambay and May-day ended in Sir Edward's favour by a head; in the next heat the result was exactly the same.

I think it was that same year he rode in two races at Howth, which, from their novelty caused quite a sensation. One was a race ridden by gentlemen in bonnets: it was very amusing, especially so to the ladies, I am sure; but the riders were quizzed so unmercifully that they did not enjoy it at all. Some of the bonnets were beauties. One gentleman, Major Paynter, of the Guards, who was one of the handsomest men in the service, went to Russell's and ordered a very expensive bonnet; when he tried it on, however, he said it did not become him at all, and gave orders to have another made; it did not please him either, and he had five made before he was satisfied, or rather he took the fifth, having at length come to the conclusion that no bonnet would become him. Lord 
Howth sported his own colours, black and white, as he wore a widow's cap; and Sir Edward Kennedy had a fox's brush sewn on to the front of his bonnet. The conditions of the other race were that each rider should light a cigar at the post, and if it was out when he came to weigh in he was disqualified.

When Sir Edward Kennedy took the hounds the pack consisted of fifty-two couple, mostly bred from the Belvoir and Brocklesly kennels. Sir Edward, finding them mute, and also, as he said, that "they would race a fox, but not hunt him," he, with great success, introduced new blood, chiefly from the Holderness and York and Ainsty kennels ; and the present pack, although quite as fast as ever, hunt to perfection.

Richard Lyons came from Gowran-Grange (Baron de Robeck's) with the hounds to Johnstown-Kennedy, and was Sir Edward's first huntsman; IVilliam Brice was first-whip, and Charley Brindley, who came from the Quorn, and who died a few years ago, was second. When Brice left, Brindley was promoted to his place, and Will Freeman, who came from the Pytchley, was second. Brindley having left with Lyons the huntsman, Freeman got first-whip place, and Tom M'Alister second. Sir Edward's first move was to expend a large sum of money on the coverts; no doubt he had a wide field for his labours, and Kildare sportsmen owe him a debt for his arduous and most successful exertions to improve the fox haunts. He was obliged to resow Arthurstown, Hortlands, and Cappagh, and three-fourths of Castle-Bagot, Downshire, Eadestown, Stonebrook, and Rathcoffey; and the following coverts were quite gone-Moorhill, 
Killashee, Three-Castles, Donadea, the Curragh, and I believe, one or two others. He expended a great deal of his own money on them, and made many of them perfect.

At the end of the season i 869-70, Richard Lyons went to England, and he was replaced by Richard Scarth, who hunted them for three years, and, like his predecessor, gave every satisfaction. He emigrated to Canada; he is there still, I believe. Rees succeeded Scarth, and hunted the pack for part of Sir Edward's last season. An accident in the huntingfield prevented him from carrying the horn for a long period.

Sir Edward's very nature was imbued with a love for fox-hunting, but he has not hunted since he ceased to be an M. F. H. When he was obliged to hunt the pack himself, as was the case a few times owing to the illness of his servants, he got on well. As a judge of hounds he was quite first-rate, and he knew the schoolmasters and mistresses of his pack-in fact, the character of every hound he had.

Mr. Edmund A. Mansfield was next M. K. F. H. When I state that he is one of the Morristown-Lattin family, I need scarcely add that he is a very general favourite; his many good qualities won golden opinions for him. He possesses an amiable and quiet manner, but by the way he always controlled the impetuous and heterogenous assemblage which makes up the Kildare "field," he proved that the suavite" in modo is often preferable to the fortiter in re. During the time he held the reins of manager he gave very great satisfaction, and the sport was very good indeed.

IVill Freeman was made huntsman when the hounds 
came into Mr. Mansfield's possession. He has now been seven years in the county as hunt-servant. He had the great advantage of serving under the best gentleman huntsman of the day as whip, Capt. Thompson, when he carried the Pytchley Horn. He knows every inch of the Kildare territory, rides well, has a splendid voice; and as the hounds always look well, it is apparent that he knows his business in the kennel as well as in the field.

Two years ago public kennels were erected at Jigginstown, one mile from Naas. They may be described as being "neat but not gaudy," and they are very commodious. Builders are at present at work there erecting stables and other accommodation, and when complete it will be a very excellent establishment in a very central position.

Mr. William Forbes, the present master, is a native of Scotland; his home in the Highlands is near a village known to tourists who have travelled to the Trossachs via Callendar. But he is well known in Kildare, where he has resided during the hunting season for several years past. That he loves the "mimic warfare" is proved by the fact that he hunts six days a week, although he often has a very long journey to the trysts. He is a supporter of steeplechasing too; though he seldom races his horses anywhere except in Punchestown, where he won the Prince of Wales' Plate in 1871 , with Huntsman, and was second with Delight. In the year following, the French bred, Heraut d'Armes, made a grand debut as a chaser, by winning the Conyngham Cup, ridden by Capt. Smith, beating Curragh Ranger, Bashful, and several other good horses; Gaskill and Kingswood also carried the 
dark-blue jacket successfully over this course. Mr. Forbes never bets, but races for honour and glory. $\mathrm{He}$ is very wealthy, and will, I am sure, turn out the hunt servants in A-r style. The county will be managed by a committee of three, who will be allowed $\ell^{\mathrm{I}, 200}$ per annum. They are Major the Hon. E. Lawless, Baron de Robeck, and Mr. Fortescue J. Tynte, three popular sportsmen, who will do everything in their power to please all parties. I may add that they are first-rate men to ride a hunt. Mr. Forbes will be allowed $€ \mathrm{r}, 000$ a year.

Formerly the hounds used to meet three days a week; during Sir Edward's time they met seven days a fortnight, and the custom has continued up to the present. Next year they will hunt four days a week.

The hounds were Sir John Kennedy's own property, and he made them a present to Mr. La Touche, since which time they became the property of the hunt.

When Sir John Kennedy took the hounds there were only eighteen coverts, or rather eighteen places known in Kildare, namely,

Killashee,

Knockrig,

Ballina,

Westown,

Kerdiffstown,

Castletown,

Harristown.
Narraghmore,

Lyons,

Ballindoolan,

Grangebeg,

Knockbruck,

Bella Villa,
"Elverstown, Ballysax, Arthurstown, Wolfstown, Turnings."

The last five being rented coverts.

When Sir John Kennedy resigned, he left fortynine coverts. 
There are now in the Kildare hunting district sixty-one gorse coverts and twenty-five woods or demesnes which are drawn and in which foxes are found.

Some say hounds are much faster now than formerly. It may be so. But one thing is certain, so far as the hunting in Kildare proves, that more foxes were killed formerly than at present, considering the number of days hounds were out. No doubt, as draining was little known, there were fewer foxes run to ground.

The following table will prove this. Taking two years during Sir John Kennedy's time, from November to April, and two in Sir E. Kennedy's, the following may be interesting.

$\begin{array}{lcccc}\text { "Season." } & \text { Days out. } & \text { Finds. } & \text { Killed. } & \text { To ground. } \\ 18 \text { 18-19 } & 52 & 88 & 41 & 17 \\ 1831-32 & 43 & 92 & 32 & 11 \\ 1868-69 & 72 & 180 & 32 & 72 \\ 1873-74 & 69 & 173 & 25 & 55\end{array}$

Sir E. Kennedy attributes the cause of so few foxes being killed in the six years he was master to the fact, that only seven cubs were killed during the six years, the rest being old foxes. Few cubs having been found, as traps were set for rabbits all over the county, and cubs were caught, they not being as clever as the old foxes to escape the mischief.

It may interest some to know how the subscription has increased, and also the field money; it would be useless to mention every time that a change occurred, so I have selected three years. 


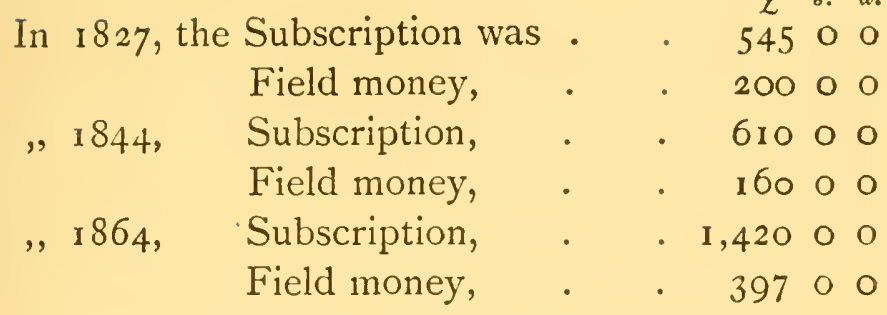

During Mr. Mansfield's mastership, Freeman's lieutenants were W. Rawle and Charles Peck; at the end of the season, 76-7, the former was replaced by Tom M'Alister, who was second whip for a time during Sir Edward Kennedy's reign, and who then went as first whip to the Queen's County hounds, where he remained until his return to this county.

The annual subscription paid to the master for some years past has been $£ ?, 100$, out of which he had to pay the expenses of the country. This amount was made up by subscriptions, donations (given by the military quartered in the district and civilians not members of the hunt), and field money. Last season, 76-7, there was a considerable surplus, the subscriptions being larger than usual, and the field money having been larger than was ever received before. Hitherto the master has had exclusive charge of the country, directing everything, and paying all charges in reference to it. From ist May, 1877, as already mentioned this has been changed. The hunt numbered in I 876-7, one hundred and thirty-eight members paying subscriptions of from $£$ roo to $€ 5$ a year. The expenditure on the kennels, stables, and house for the hunt servants amounted to between $£ 3,000$ and $£ 3,500$. Previous to the building of the present kennels the hunt establishment was kept at the private residence of the master, who was always a gentleman of the 
county, living and having extensive premises in a central position; and to that class the selections of masters had necessarily been restricted. For the future the hunt will not be subject to any such restrictions, and will be free from the embarrassment to which, on several occasions upon the occurrence of vacancies of mastership, it has led. The admission of members to the hunt is by ballot. The first meet is held annually on the first Tuesday in November at Johnstown Inn, and on that evening the members dine together at the Royal Hotel, Naas, which is considered the head-quarters of the hunt; and they give a ball each year, generally in the month of January. Mr. David Mahony, of Grange-Con, Athy, has for some years past acted as honorary secretary, and this esteemed sportsman is a very able Chancellor of the Exchequer. Several gentlemen subscribe very liberally to the fund. His Royal Highness, the Duke of Connaught, is an honorary member of the hunt, and a very liberal subscriber. The popular soldier prince frequently honoured the meets with his presence last season. He rides remarkably well, and is, undoubtedly, a first-rate all-round sportsman; his many estimable qualities have earned for him a deserved and widespread popularity.

Kildare is, undoubtedly, a fine hunting country. The "territory" is at least forty miles long and twenty miles wide, including within the bounds a considerable portion of Wicklow and Dublin. Many favourite fox haunts are situated in close proximity to the "land of brown heath and shaggy wood," the IVicklow mountains-but the highlands over which we often follow the "pied beauties" are quite rideable 
though nags who have " joined the band," no matter how slightly endowed with musical propensities, find it often impossible to live with them in these hilly hunting grounds. Over the hills in the neighbourhood of Tinode, Coolemine, and Goucher's Gorse, all favourite resorts of the fox family, hounds generally carry a good head. If your horse is clear in the pipes, and clever enough to negociate safely the high, rotten banks frequently met with in these parts, there is no reason why one shouldn't be with the hounds, as the going is good. The "cream" of these truly happy hunting grounds is the neighbourhood of Punchestown, Kilteel, Dunlavin, Ballytore, Maynooth and Kilcock. There is nothing to stop a good man, well mounted, in this fine grass country, where the fences are safe and sound, albeit "stiffish." There is just enough woodland to be pleasant in Kildare, the many coverts are nicely situated, and foxes sufficiently numerous. Feathered game preservers are almost unknown. A few years ago rabbit trapping was carried on to such an extent that fears were entertained that foxes would be entirely exterminated out of certain districts. But the then master, Sir Edward Kennedy, drew attention to the fact, that the foxes were so often destroyed by the trappers, that something should be done to prevent the obnoxious custom. A meeting of supporters of fox-hunting was held, and several gentlemen who were in the habit of having traps set for the destruction of poor "bunny," when they were assured of the amount of injury done towards the fox-hunting portion of the community, in the most sportsmanlike way promised not to allow trapping to be carried on; and, I think that but little injury is inflicted 
in this way now. There are more resident gentry in this county than in any other .in Ireland, and a vast majority of them are fox-hunters.

For some years past a growing evil has caused serious apprehension amongst hunting men; I allude to the erection of wire. In some districts it is quite impossible to ride to hounds, owing to this objectionable practice. The landed proprietors (for I am sorry to say they set the bad example) and farmers do not use wire for the purpose of interfering in any way with the hunting. The great majority of them are delighted to see the hounds in their neighbourhood, and many of them are hunting men. Economy is their motive ; I certainly think their notions on that score are very mistaken ones. No doubt wire is easily put up, but I opine that the posts becomequite rotten after about four years, and, on account of the frequent repairs required, I am convinced that making wire fences is, generally speaking, a penny wise, pound foolish proceeding. Horses, sheep, and cattle are frequently severely injured by being caught in wire. It would be labour in vain on my part were I to write at length, pointing out the manifold advantages derived by all classes, the tenant farmers particularly, by hunting. Any injury done to their lands is truly insignificant in comparison to the advantages they derive, notably from the increased value of horses, oats, hay, and straw. And the fact must be so perfectly apparent to all that I need not, though I could very readily, point out the benefit derived from this pastime of princes-the most glorious of all amusements. Absenteeism is the cause of many evils, to it may be attributed a great deal of the poverty of our countrymen; and were it not for hunting, those 
who spend the most money amongst us would migrate to foreign lands.

Hunting affords pleasure, is a healthful recreation which leeps at home in our country the flower of the Irish aristocracy, yields wealth to willing hands, cements good fellowship, puts money into the pockets of the landed proprietors (by increasing the value of their property), tillers of the soil, the shopkeeper, the artizan, the peasant, in a word, the entire population.

I happen to know three very wealthy sportsmen, who intended coming to reside in this county last season for the winter months, but seeing so much of the country wired, they changed their mind. These were men with plenty of means and large studs, who would have spent a great deal of money here. I sincerely hope that the landed proprietors who have wire fences on their land will remove them, and I am sure many farmers will follow the example of a wake so stimulative, and "go and do likewise" before they cause further injury to their own interests. I believe that love of sport of all kinds, as well as of foxhunting, is inherent to the nature of every Patlander; and I hope that those Kildare men, whose occupation is the patriotic one of making "two blades of grass grow where one grew before" will support foxhunting. If they " ware wire" the day will never come-not even on the arrival of the long. expected New Zealander on London Bridge-when the gorse is uprooted, and the cry of the foxhound no longer heard within the bounds of "fair Kildare." Fences of all sorts and sizes are to be met with in this country. In places where wire is not used you can go sailing away if your heart is in the right place, and you are well mounted. Walls or timber you seldom meet; 
but to be a safe conveyance, your horse must be a " tip-top" bank jumper, and a bold fencer.

The number who comprise the "field" average about $\mathrm{I}_{50} \mathrm{O}$, including many who would be regarded as first-flight men in any age or in any country. I have given in my reminiscences of other hunts the names of those who comprised the leading brigade in the days of "auld lang syne," as well as those of the present. But in this instance I will not presume to make selections, there are so many worthy of honourable mention, that I could scarcely make up my mind as to who are deserving of being included in the schedule. Although I have had very many good days hunting with these grand hounds, and ample opportunity of seeing, and, I may add, did see them often race, "head up and sterns down," when in the front rank were gathered the "good and the true ones." The field, too, invariably includes visitors from Meath, Dublin, Queen's County, and an occasional pleasure seeker from the Shires, and other " birds of passage," such as officers of the Dublin and Newbridge Garrison. The thought may strike some that I might mention a few of the flyers who have ere now gone to ground without fear of giving offence. I thought of doing so, but I have not yet lived to comb a gray hair, my " tatch" is unstained by those silvery indications of the flight of youthful days, so my recollection does not extend very far back, and I will not add to the few I have already particularised.

Several of the best men of the present day are named the "Men of Kildare," which I may add was composed by me after a good run with the Kildares in 1876 . 


\section{THE MEN OF KILDARE.}

WHEN autumn to gold turns the leaves on the trees, And the swallows depart for their flight o'er the seas, While the river goes swollen, the ocean to meet, With a whisper as soft as a lullaby sweet, We look to our " scarlets," our "nags," and our "cords," For a run with the "Meaths," or a day with the "Wards." Both are good in their way, but they cannot surpass A burst with our foxhounds across the "short grass."

\section{Chorus.}

Bravest of men are the men of Kildare, Tho' fortune prove fickle they never despair. Would you still wear your laurels, I'd have you beware How you ride to our hounds when you come to Kildare.

Arthurstown's tried, he's at home, a sure find ;

Gone-away! they are off in the teeth of the wind. There goes Willie Blacker of sweet Castlemartin; You'll find the right place he has ever his heart in ; Beside him Will Kennedy, ex-master of hounds, Who could ride a flat race, and give most of them pounds. There, too, goes his brother, a jolly good fellow, And Mansfield, late master, whose heart is still mellow.

Chorus-Bravest of men, \&c.

In grand style the double is cleared by bold Lawless ; Lord Cloncurry, close up to the front rank they call us. Whilst Beasley looks calm, as if winning a plate, And O'Ferrall, as ever, despising a gate; And the Lord of Clonmel, who enjoys all the fun, Whilst Morris flies past, though recording the run, Colonel Forster, who oft brought the "tartan" in front, And Forbes-all good sportsmen are seen in the hunt.

Chorus-Bravest of men, \&c.

See La Touche and the "Baron,"* each obstacle clear, While Sir Higginson's gray jumps as clear as a deer. By Downshire they race on to Punchestown course, The fox heads away then for Elverstown gorse (Here Wakefield the field often led a swift pace), Kilbee and his daughter are still in the chase.

Reynard changes his course, but he dodges in vain ; $\mathrm{He}$ never will shelter in covert again.

Chorus-Bravest of men, \&c.

* Baron de Robeck. 
Charley Warburton, known as the great welter-weight, Never looks for a gap, or unclasps a field gate;

While Tynte, the kind owner and lord of Tynte Park, Seems as careless and gay as if out for a "lark."

Say who is the rider of yonder coal-black,

Who looks as if moulded upon the steed's back, As true as I live, I could stake my life on it,

'Tis his Highness himself, the young Duke of Connaught.

Chorus-Bravest of men, \&c.

Diana herself might look on with surprise,

At the feats of the ladies who strive for the prize;

Why Reynard's been known to be caught by a blush, And gallantly died to present them his brush.

But Reynard, being Irish, what less could he do,

With lovely Churchill and fair Beauman in view.

Other countries may boast and with pride of their pearls, But none can compare with our own darling girls.

Fairest of maids are the maids of Kildare,

When their cheeks have been flushed by their own native air, If you'd keep yourself heart-whole I'd have you beware, How you meet the soft glances they give in Kildare. 


\section{CHAPTER II.}

\section{THE CURRAGHMORE.}

You ask me to give you some details in connection with the present "Curraghmore." I wish you had a better hand to do it for you; but as you have not, I will tell you all I know of that fine hunt; but first draw your chair nearer the fire, refill the pipe, have a glass of grog, and pay the same attention to me, for I can't talk without a drink and a smoke.

You must know that the present name of this hunt has been but recently given it. In olden times the hounds that hunted this part of the country were called the "Waterford Hounds," the "Tinvane Hounds," and, I think, there were one or two other packs. When "the Marquis" took the country, he bought up all these hounds, hung nineteen-twentieths of them, and called the pack he established "Lord Waterford's Foxhounds." When his brother succeeded to the title, in 1859 , he, being a clergyman, did not like that cognomen, so he called them "The Curraghmore Hounds;" and again the present Marquis changed the name two years ago to "The Curraghmore."

Well, so far I have accounted for the title of the hunt-I will now try if I can go back to the find, trace it through its long mu, and account for it up 
to the present, when I shall leave it still running, and may the day never come when we will have to give it a whoo-whoop!

Soon after Henry, third Marquis of Waterford, married Hon. Louisa Stuart,'he came to reside at his ancestral mansion, Curraghmore, and wished to establish a pack of foxhounds there; but from want of foxes and of hounds he was unable at the time to gain his end. He, however, about the year I 840 , bought a pack from Captain Jacob, of Mobarnane, in the county Tipperary, and took over the country he hunted. He moved the establishment to Rockwell, which was more central, and showed very good sport for three or four seasons. His lordship was personally most popular in Tipperary, but some of his employées were not; the consequence was that feuds sprung up and bad became worse, until at last some rascals set fire to the kennels. This annoyed his lordship so much, he gave up the country in disgust, to a committee of county Tipperary gentlemen, with fifty couple of hounds, five horses, and a subscription of $£ 100$ annually. This was about the year $\mathbf{1} 848$. The present Mr. Henry Briscoe, of Tinvane, and the late Mr. William Fitzgerald, had then each a pack of hounds. The former owned the hounds he hunted, and they were well bred, and hunted hares as well as foxes; but the latter was a subscription pack, and consisted of every sort, and would hunt anything from an earwig to an elephant. They once, after a blank day, ran riot after a buck goat and ate him! You may laugh, but it is a fact; Billy Johnson of Waterford is alive now, was out that day and saw it occur. Well, Mr. Briscoe had well- 
nigh killed every fox within the narrow limits of his country; and though they say he used sometimes to accidcntally draw a neighbouring hunt's cover on the chance of a find, he was glad to dispose of his pack to Lord Henry, as I have said, in 1848. To get rid of the other pack and get up the country, his lordship bought them from the Waterford Club, of which Mr. Fitzgerald was then master.

Lord Waterford set to work with a will to establish a pack and a country. With the aid of Johnny Ryan (whom he brought with him from Tipperary, and whose father and grandfather hunted the Grove hounds before he did so himself), and the kindness of his English friends, his lordship soon had together as well bred a pack as was then to be found. He had more trouble stocking the country (for ' 48 was a troublesome time, particularly with Tory landlords); but "the Marquis" was a favourite with all, and before long he had a good show of foxes. At this time his country was bounded by the limits of the county Waterford, and the little bit of the "Welsh" mountains, hunted over by Mr. Briscoe; but in a short time Sir John Power, who had the Kilkenny country then, gave his lordship that portion of the district which lay within a line from Carrick-on-Suir to Innistiogue, taking in Wynne's Gorse, Kilmoganny, Castlemorris, and Kiltorcan-along the river Nore to New Ross, I think_but I am not quite certain if Woodstock, Brownstown, Annaghs, Lucy's Rock, and Glensensaw were in it, I rather think they were not, and that Sir John kept them to hunt when he drew the Ross district. At all events, Lord Waterford, with the covers I named, got Carrigtruss, Tory Hill, Knock- 
brack, Coolnahaw (now cut down) and all the Welsh mountains from Clonassy to Kilmacoliver, as well as the jolly little gorse cover of Killeen, also Snow Hill. This was a great addition to his territory, and he showed his appreciation of the compliment by hunting it two days a week, and the Waterford country one day a week. Very good sport he showed; and though I consider he was not a good judge of a horse or a hound, he made a capital M.F.H., and was respected by all classes. Johnny Ryan hunted the hounds till Lord Henry's death. He had some very good whippers-in, notably, Clancy, Bolger, and poor Billy Barry. There never was a cheerier fellow than Billy; but he had a hasty temper, and when vexed would "cheek" any one. He was whipper before this to Sir Robert Paul when he kept harriers. One day, Sir Robert, who hunted his own hounds, viewed a hare going away, and blowing his horn, cheered his hounds on to her. Billy, at the other side of a patch of gorse, viewed another away, and began cheering the hounds on to her; hearing Sir Robert in a contrary direction, and thinking no other hare was on foot but the one he saw, lost all patience, and sung out: "You damned fool, what are you blowing there for, don't you see she is gone this way!" Sir Robert was not the man to stand this, so galloping up he knocked Billy off his horse, and gave him his "walking ticket" next day. Billy then came to Lord Waterford. What a rider he was! much better horseman than whip, for though I never saw a man who could get his hounds out of cover faster to a huntsman's horn, he would much prefer to ride to them than to stay behind getting on tail hounds. Poor Billy-he died of consumption, and 
one of the last men he spoke of was myself. As there are now, and ever shall be, there were then hard riding and good men to hounds here: Sir Richard and Henry Cox, Captain Fleming, Ned Lalor, Belcher, William Power of Seafield, "Parson" Gregory of Fiddown, Tom Sheppard, "Old Sir John" and the late Sir John Power, Johnny Power of Gurteen, Bailey of Norelands, Harry Jephson, Larry Dobbyn, Captain Doyle, Weekes of Ballymountain, John Walshe of Fanningstown, Higginbottom of Garnarea, Lord Bessborough, John Jones of Mullinabro, Tom Lalor (son of Ned), and Henry Briscoe. They are all dead and gone, except the four last-named, and may it be long before their whoo-whoop be rung, for never lived four in whose veins sporting blood ran brighter. I must stop a minute to drink a toast to the memory of those who are gone to ground, and to the long life of those four who are still above it. Fill full, and no heel-taps, the first in mute silence, and the latter with a view-hollo! Well done, you have a good voice still, and it tallied many a fox away in its day too, I know.

Many of those I have named were old men when Lord Waterford first hunted this country, and mostly belonged to the Kilkenny hunt, but they always came out when his lordship drew their side.

The covers in those days were the same as now exist, except Coolnahaw, Ballinaboola, and a few small ones which were cut down, and those newly made by the present Marquis: but to them I had better give a separate description anon.

They used to have famous runs then; one celebrated silver-haired fox took them, I think, four 
times in one season a spanker from Tory Hill, by Knockbrack into IVoodstock; the hounds could never kill him. He died in a wet drain, into which they ran him at last. That puts me in mind, Billy Johnson (I beg his pardon, Captain Johnson, but he is a good sort, and won't mind familiarity), before this time got a silver-haired dog fox from off a ship that came from Norway or some northern clime, and they let him go on Tory Hill. He was killed soon after, but not before he mated with some of the aboriginal vixens. The fox just mentioned was one of his breed, and we often meet a light-coloured fox about there now. Only two years ago we killed a silver-haired vixen near Cat's Rock that gave us several good runs. Another magnificent run was had in March, 1859 , during his lordship's absence at the Liverpool Grand National, where he went to see his horse, Ace of Hearts, run. He was much put about when he heard of it, for he did not like losing a run. A fox found in Corbally, ran over Milltown Hill, over the Harristown bottoms, through Killeen, straight on through Castlebannon, and to Coolnahaw bog, a point to point distance of nine miles. Here he turned to the left, skirted the verge of the bog, bent to the left again, and straight for Kiltorcan, within a mile of it he changed his course and went down through the Greywood, across the railway at the tank. At this time there were only four men with the hounds, Mr. Briscoe, on a chestnut stallion he called Sir William, got a bad fall on to the railway. Mr. Harry Sargent, then a very young man, got over by his horse's wonderful performance over a stone mason-built stile between a locked gate and the wire paling of the railway. It was 
a narrow squeak for him though. The fox from this made for Killeen, but was headed away from it by the keeper, old Tommy Knockmore (I must tell you some yarns about this man, by-and-by); he ran an inside line to the one he ran first, through the top of the Greywood again, and to ground near Ballyhale. He was not a yard in, and could easily have been taken out, but Lord Bessborough, who was up at the time, would not allow it. The men who rode this hunt from find to finish were, Johnny Ryan on "Merry Man," Billy Barry on "Magpie," Harry Sargent on a bay hard-pulling horse, George Malcomson on, I think, a thoroughbred mare called "Eugenie," and poor Fred, who died the other day, on "Bad Boy." This run could not be less than from twenty to twenty-five miles, and the pace was sustained all the time, and no check longer than five minutes was in any part of it. Henry Briscoe, till his fall in the railway, Clem. Saddler, poor David Malcomson, and a few others, went well also. I heard Lord Bessborough say-and he is no bad judge-he never saw a finer run than this one was.

I have just recollected a wonderful run which is said to have taken place (but I don't believe a word of it, y'ou may if you like), so I will tell it to you. It was when Fitzgerald had the hounds, and an old chap named Delahunty (a good name for a huntsman) hunted them. They found a fox in Mount Neil, ran him by Granny up to Clonassey, on to Tory, by Knockbrack, into Snow Hill, on by Lucy's Rock, through Rossbercon, on by where Weatherstown cover is now, through Coolnahaw, and killed him near Kiltorcan in the dark night! Now, if this run ever 
did take place, fifty miles must have been gone over. I have mentioned the gentleman's name already, who told this run to me; but after what I have said of it, I would be afraid to tell who he is; but he swears it is a fact, and that he finished it too, and rode home through Mullinavat with Captain Doyle (he is dead though), where they both gave meal and water to their horses, and brandy and water to themselves till they got drunk! - small blame to them after such a run!

I am now coming to a gloomy portion of my tale. The facts have, as you and every one else know, then, and ever since, when alluded to, cast a pall of darkness over the brightest scene of a fox-hunter's career-the death of Henry, third Marquis of Waterford-" the Marquis," as he was, and ever will be styled.

On his return from Liverpool, where he had not the good fortune to see his horse even placed for the Grand National, he heard of the extraordinary run we had in his absence, and which I have just described. A day or two after, well remembered by all to be the 29th of March, I859, his fixture was Castlemorris, the seat of his old friend and stanch supporter of fox-hunting, John de Montmorency (light lie the sods over good "John de Mont's" grave). A straggling, slow run out of it to ground in Glenbower was the first we had that day. His lordship got his second horses at once, and trotted off to Corbally, to find the good fox that gave us the run ten days before. A very large field was out, as was always the case when he met there. We found a fox in Corbally, which took us over Milltown Hill, as did the other, but he 
turned back to Corbally again. Crossing the road, the hounds running up the hill to the cover with three or four men with them, his lordship's horse (one I never admired, called Mayboy, not up to fourteen, much less sixteen to seventeen stone), bungled over a little fence into the road; he did not come down, but his lordship fell over, right on his head! He lay motionless till picked up by Harry Jephson and Johnny Ryan, his steeplechase jockey, who always rode second horseman to him. Dr. O'Ryan, who was close by, also jumped off at once and examined the prostrate form of as fine a sportsman as ever fell in the hunting field. When asked in frantic strains by Jephson what his opinion was, he replied: "May God have mercy on his soul, for it is departing from him this moment."

Need I dilate upon the scene of consternation that followed. No; long ago as that day is now, I remember every particular of it, and shall as long as "life's memory" lasts. Harry Jephson was, perhaps, Lord Waterford's dearest friend, and upon him devolved the direful necessity of going before to Curraghmore to break the awful tragic occurrence to the widowed lady who "loved her lord so well." He avoided not the duty, but at once proceeded on his dreadful errand. Directly Lady Waterford saw him she guessed his object, and at once exclaimed that his lordship was killed! Yes, poor soul! she had always a presentiment of such a fate befalling him!

After Jephson's leaving, his lordship was laid in 
a donkey cart, and conveyed some miles before a horse's cart was procured; he was then transferred to it. Can I ever forget the sight of that mournful cortège, passing through the quiet village of Templeoram that evening about 8 o'clock? The night was dark, but there was a slight moonshine, which shed its ghastly rays upon some twenty horses being led by countrymen in front, and on the horse and cart, with the body of the dead sportsman, stiff and cold, in his red coat, with a cloak thrown over him, his feet extending over the end of the cart (the tail-board being removed to give them room), and held together by his faithful servant, Johnny Ryan. Close after the cart followed some twenty of those who hunted with his Lordship that day, all walking in silence, and accompanied by a large number of peasants. And to complete the dread picture, one hound followed close by the cart.

No use dwelling longer on these sad details ; suffice it that his lordship's remains were transferred from the cart to Lord Bessborough's break at Bessborough, and conveyed to Curraghmore, escorted by Jephson, who came back to meet it, Johnny Ryan, and one or two more.

There never was a larger funeral collected together in Ireland than that which was marshalled in the courtyard of Curraghmore on the morning of "Lord Henry's" funeral, and I believe never was one followed to the grave by more tmily sorrowful men. Not a sound or a whisper could be heard, as the single file of black-caparisoned carriages wended its weary way along the meandering drive from the courtyard to the quiet little graveyard of Clonegam. 
Enough of the melancholy narrative!

The auction over, Lord John, the fourth Marquis, in that princely, off-hand manner, which was the characteristic of so many of his kin that had gone before, presented to the hunt thirty-two couple of the picked hounds of the kennel, four horses, the best also, and a subscription of $\ell_{0} 100$ a year. At a meeting of the gentry of the country, Mr. Henry Briscoe, of Tinvane, was unanimously chosen to be master of the hounds, with Ryan as huntsman, and Billy Barry as whip, and the pack were transferred to Tinvane.

A subscription was raised (of course all know that Lord Vaterford hunted the country at his own expense solely) which was headed by Messrs. David, George, and Fred Malcomson, and the Earl of Bessborough, with $£ .150$ and $€$ I 00 respectively.

Sir John Power only gave Lord Waterford that portion of his country I have mentioned, while he hunted the country; so at his death a new arrangement had to be come to, which was this-they took back Castlemorris, Wynne's Gorse, Kilmoganny, Windgap, Kiltorcan, Sir John's Gorse, Coolmine, and Killeen, and if Woodstock, Glensinsaw, Brownstown, and Lucy's Rock, were given his lordship, them also, leaving us only that portion below Carrigtruss to Snow Hill, taking in Tory Hill and Knockbrack, for which we paid the Kilkenny Hunt (then a club, Sir John Power having given it up to the country) a rent of $£ 50$ a year, which Lord Bessborough paid in addition to his subscription of $f_{1}$ IOO a year.

Briscoe only hunted two days a week, and started with Merryman, Sunshine, Cheasty, and Wall, given by Lord Waterford, Stretcher and other horses 
the hunt bought for him, and thirty-two couple of hounds.

Lord Henry, as I said before, was not a good judge of either a hound or a horse, the former he knew less of than the latter. A horse had but one (certainly a good one) recommendation to him-going well-no matter what his shape was, if he saw him, go through a good run, he would buy him if he could.* No doubt the pick of the kennel and stable we got, and when they were chosen by Henry Briscoe, it is easily supposed he took none but the right sort, for no man is a better judge of a hound or a horse than he. Not good, however, was the best, and it took Briscoe some years to make them to his liking, and that is as near perfection as possible. Any man who remembers the hounds when he got them, and when he gave them up to the present Marquis, and who knows anything of what a pack of hounds ought to be, must agree that a more improved pack was seldom made in so short a time.

One word now about my dear old friend "Henry." We all call him "Henry," from peer to peasant, the latter dubbing him "Hinry," or if very respectful, "Hinry Sur;" but first we must drink his health. So fill your glass again; and though we coupled him before with three others, we must now give him a bumper with "three times three, and one cheer more." He is now as well and as "fit" as he was at the time of which I shall now tell you, and may he long continue to be so. Take the time from me. Hip, hip, hurrah for Henry Briscoe!

* I do not share my informant's opinion as to Lord Waterford's judgment. The owner of so many chasers and racers could never have lacked discrimination in his purchases. [Author]. 
From the way you are questioning me, I have an idea you want to write a book; but I don't care whether you do or not. Every word I tell you is gospel, no man can controvert it. And nothing I have told you, or will tell you of this hunt is truer than what I now tell you of Henry Briscoe.

Never was a man, taking him " all round," better qualified for a M. F. H. than he. He knows how to mate his breeding hounds, so that the progeny may reasonably be expected to inherit the goodness of the parents, while the faults (but he never breeds from a really faulty hound) may be mitigated or extinguished. When the puppies come in from walk he knows the ones to put forward as well as any man living. In their early kennel training, and horse exercise, he is a disciplinarian. When he first enters them to their game, his keen eye (though he often looks at them through his little stringless glass, with a twist in his dear old head, that we all know so well) selects, without error, the puppies he means to give to his friends. Therefore when the first day of the season arrives, he has his year's entry nearly as steady and free from riot as his old hounds; and from his long experience and natural sagacity, the condition he has got them into is simply perfect, and that condition, by the most astute kennel management, he keeps up the entire season, no matter how severe it may be. If he carried the horn himself, as he did for so many years, fer gentlemen huntsmen (or professionals either) could handle a pack of hounds in cover, or through a long run on a cold-scenting day, and at the end account for his fox, better than he. $\mathrm{He}$ is a first-rate judge of a horse, as is testified by his being 
frequently asked to adjudicate over the hunter class at horse shows. He always looks to the blood, bone, and quality in that animal, as he does in his hounds; and when he has bought a horse to his liking, can't he ride him though! None of your bullying, bustling fellows, who are always in a hurry, and never where they ought to be, except when they are in a ditch, but quiet and steady, with the motto, "be with them I will." And such an eye as he has for a country!

Now comes the greatest of all qualifications in a M. F. H., and this he has, if possible, to a greater degree than any of the others. The way he keeps his field in order, and the way he manages the women, old and young, who come for damages or loss of fowls! His hearty good humour, and continued propensity for cracking jokes (never practical or ill-natured ones), made him such a favourite that we always did what he told us, and if, by chance, we did not, his shrill-noted rate, sometimes emphasised with a strong word or two, would very soon bring us back. Then the women, with their fowl claims, devil a rap he'd give half of them, yet they would all go away contented and preserve the foxes for him for a kind or joking confab, better than they would for others who would pay double their claim without the same cheerfulness. He knows every man, woman, and child in the country, and has a kind word and joke for them, so they all like him, and would do anything for Mr. "Hinry."

I ought to have told you when speaking of "the Marquis's" days, that we used to have terrible hard and jealous riding between the Waterford and Kilkenny men. About the years I 857-8, some letters appeared in one of the Kilkenny papers contrasting 
the riding of the Kilkenny men with the Waterford, extolling the one and depreciating the other, the natural consequence of which was jealousy; and when we met the Kilkenny men, as we always did when Lord Waterford drew the Mullinavat or Castlemorris district, there was "hammer and tongs" between us. I well remember one day we met at Mullinavat, then a very favourite trysting-place, and where excellent eggflip was made and administered by Miss M'Donald, the pretty daughter of the inn-keeper of the town. Much rain had recently fallen and the country was heavy and the rivers flooded. A very large number of horsemen met his lordship, such clinckers as *Lord St. Laurence, Bryan of Jenkinstown, Mulhallen Marum, the Smithwicks, Ralph Bunbury, Izod of Chapel Izod, and a host of others representing Kilkenny; while from our side came Glascott of Alderton, who, though a IVexford man, used always hunt with us, Jephson, Sargent, Strangman, Larry Dobbyn, the three brothers Malcomson, Johnny Medlycott, Arthur Roberts, and others, all hard riding, determined men to go.

Well, we found in Killeen, and the hounds got a good start close to the fox; they raced him at terrific pace as if for Clonassy, but turned down to the Mullinavat river opposite Earl's Rath. The river was swollen nearly level with the fields, and a rushing torrent it swept along. The hounds hesitated for an instant on the bank, but the mass of horsemen that came thundering down upon them left them no alternative but to dash in and swim across.

* The present Lord Howth, then master of the Kilkenny hounds. 
Seeing this, the leading men charged the river in their stride, though it was fully twenty feet from bank to bank. Of course all got in, some over head and ears, others, more lucky, escaped with a partial ducking. Never was known more grief; fellows were for hours trying to get themselves and horses out, while the hats and whips that floated down the stream would stock a shop. Glascott was first at it, and though as fine and cool a man to hounds as ever sat in a saddle, when roused he was $a$ caution; and the letters in the papers did rouse him! Others of us got over after him, but we carried the hounds on for a mile, and so lost a fine run. The fox ran to the river brink, but seeing the state it was in, slipped along its bank, and ran into Clonassey, while we ran the hounds on to Earl's Rath. I often wondered Lord Waterford allowed this sort of thing, for it spoiled many fine runs, as it did this. But I think he used to rather enjoy it, for it was terrible to see how some of the young bloods rode at each other; and dire was the grief many of them came to, for no fence would stop them. Ah, me! what pluck we had then!

Henry Briscoe's first meet, on becoming master of the Curraghmore hounds, was at the Waterford Club House, on Tuesday, r 8th Oct., I859. Johnny Ryan hunted them for two or three seasons, then Briscoe took the horn himself, and old Johnny emigrated to America. Barry was parted with, I think, before the season began, and Harry Hardy, from some English pack, filled his place for a year as whip. He then went I think to Louth, where he is still, I believe. John Duke was taken about the year I86r. He came from the East Sussex. Briscoe showed the most 
wonderful sport, I may say, all the time of his mastership, but notably in the season of $1861-2$, in which he hunted sixty-eight days, killed forty-one foxes, and ran sixty-two to ground, had twenty first-class runs, of from thirty minutes and upwards, and twice that number of short, brilliant spins of ten to twenty minutes. It was in this season we had the celebrated runs from Owning and Annefield over the Wynne's Gorse country, through the Kilmoganny and neighbouring plantations, and far into the Kilkenny country, all with the same fox, as far as Kilmoganny; but here the "wily rover" used generally give us the slip, and sagely shift the hounds on to the line of a fresh fox. They were, on 1 7 th December, 1861, I hour and 40 minutes; 28 th January, 1862, 4 hours and 5 minutes-31 miles; $24^{\text {th }}$ March, 1862, I hour and 25 minutes; I Ith April, 1862, 2 hours and 5 minutes. That excellent sportsman, taking him as a rider to hounds, a judge of houn's and their management, as well as a crack shot, Wm. Madden Glascott, of Alderton, to whom I before alluded, wrote a little brochure on this season's sport, under the nom de plume of "A Visitor." As I have a copy, I will read you the account of one or two runs, as given by him, and coming from such a judge, they will be worth your attention. How well I remember him sailing, as he used to do, to hounds on his famous bay horse, "Schoolboy," and how I used to envy his performances, though he was then past the prime of life: but his heart, as it is this moment, was in its right place. This is what he says: "January 28th, I862-CastletownFound our friend again at Talbot's Gorse, close to Annefield; had four mortal hours and five minutes 
again at him over the Wynne's Gorse country; away to Mr. Wall Morris's plantations, to near Callan, to near Kells; far away into the Kilkenny Hunt country. This run (though too much of a good thing) was for pace, country, and length, such as a man can only expect to see once in his lifetime, and we believe the hounds had all the latter portion of it to themselves. No one up but the master, and nowonder, few even attempting to struggle on to the finish ; and that good man, Mr. Mulcahy, losing his famous chestnut mare, found dead in her stable next morning, no doubt from the severity of the run."

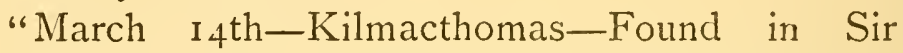
Edward Kennedy's plantation; ran to near Woodhouse, back by Comeragh Lodge, and into the Dungarvan country; one hour and twenty minutes - very fast, to ground on an island in a pond." I saw this run myself, and it was as fine as man need wish to see. Same day we had a tickler from Kilmacthomas Gorse up to Croghawn mountain-terrible pace, but only fifteen minutes.

Glascott gives his opinion in his little pamphlet on the hounds, which I will also read you: "The hunting hounds consist generally of twenty-five or thirty couple, standing, on an average, about twenty-two and a half inches, of great length, bone, and muscle, which, on a near inspection, surprises you, as, looking at them sideways from a little distance, as they step along to cover, brought out, as they are, in such condition (fit to go), they appear light, lengthy hounds. We cannot say what the kennel discipline is, but when brought out, they appear to me as near perfection as it is possible to bring hounds. In the field they depend 
upon themselves (for hunting is the order of the day), and with a fair scent, and once clear of the field, they require little interference on the part of the huntsman."

Mr. Briscoe got into a bad state of health towards the end of $1868-9$ season, and had to give the horn back to old Johnny Ryan, who had returned from America. At the end of $1869-70$ season, the present Marquis of Waterford took the hounds. His father, the fourth Marquis, died on the 6th of November, 1866 .

One of the first proceedings of his lordship on getting the hounds was to set on foot a testimonial to Mr. Briscoe, which was liberally subscribed to by not alone our hunt, but by many hunting men in Ireland and England. It was presented to him at a banquet in Waterford. Lord Waterford promoted Duke to the horn at once, and very soon it was apparent to all what a good choice he made; but I will tell you about the hunt servants just now.

Lord Waterford's first card intimated that he would hold his first meet at the Waterford Club House on Tuesday, the r8th of October, 1870, just the day eleven years from the time Briscoe began after his uncle's death.

The country was then the same as what Briscoe hunted; but after a while his lordship was given, by that stanch good sportsman and right good fellow, John Going, then master of the Tipperary hounds, all the country from Newtown Hill to Slievena-mon mountain, and from Kilcash to Kilsheelan. His lordship also got from the Kilkenny hunt about 
the same time, Brownstown, Glensensaw, Annaghs, Lucy's Rock, and Mullinahone Hill, with Woodstock a neutral covert, which gave him all the Kilkenny country from Carricktruss to Woodstock, and round by the rivers Nore and Suir, except Killeen and Kiltorcan; these he fought hard for, but the Kilkenny men loved those famous covers too well to part them.

Much was required to be done with the fox haunts all over the country. Many had overgrown themselves, others were badly situated, while many places required new covers to be established in them, so Lord Waterford lost no time in setting about the task, one which would be almost impossible to others to accomplish, but the facilities he had enabled him to do much. He established gorse covers in Weatherstown, Mullinahone, Rochestown Hill, Earies Gorse (given him by Lord Clonmel), and enlarged Carrigtruss, and Galways cover. These are mostly in the new countries he got from the Kilkenny and Tipperary hunts. In the Waterford country he planted Passage Hill and Carrig-a-nure, where none existed before, and from both of which he has been repaid by having some rattling runs. Very few have ever equalled him in becoming in so short a time so good a judge of a horse and a hound. He is a professor in the art of judging the two, and the consequence is, he has in the Curraghmore kennels and stables this moment a pack of hounds and a stud of horses that may be equalled, but is not surpassed, by any establishment in Great Britain. I will by-and-by dwell more particularly on them.

His lordship takes no subscription, and has shown 
wonderfully good sport ever since he took up the hounds, which, by the way, were his own, as they were only lent to us by his father; and never was there a more brilliant season than the one now drawing to a close (1876-7). But as the many fine runs we had are so fresh in all our memories, there is no use telling of them now, better go on to describe the country, the covers, the men who hunted with his lordship, the hounds and horses, and finally, wind up with the general opinion formed of his lordship as a M. F. H., and, perhaps, tell an anecdote or two of "old times." By that time you will be tired of listening, and I of telling, so we shall then bring the narrative to a close.

I should have mentioned a famous run we had with Briscoe on the 3oth December, 1862. Found in Glenbower, he broke at the Fanningstown end, ran round Garryduff, down by Tom Shea's house, on to Carrigtruss, through it, on for Castlemorris, as far as Boolyglass, then to the right, down to Moonruha bog, along its verge, passing within a field of Killeen, on by Mullinavat, for Clonassy, as far as the Harristown road, then to the left, crossed the railway near the station, and ran into him facing for Tory Hill. This was a famous run, over fourteen miles in one hour and twenty minutes. Harry Sargent on the Squire, and Joe Strangman on Bretby, had the best of this run all the way from Carrigtruss, which was the cream of it. Dr. O'Ryan, Hon. Walter Talbot, and some others went well too.

In Briscoe's time we used at first have an interchange of meets with the Tipperarys every season. IVe used to go to Fethard and they to Carrick. These reunions always produced immense meets and very 
hard riding, and we generally had good sport and always the greatest fun. The Tips are the most hospitable people under the sun. A Cead-Mille-Failthe for all. Poor old John Going! He was a good soul, and so glad to see us all! Peace be to his ashes!

You remark I have not told you of many runs we had in the Waterford country. I forgot them or mixed them up, we had so many. We had one about six years ago, from Gardenmorris, through Carrigeen, by upper and lower Ballyphilip, bent to the left, through Knockaderry, to the right by Mrs. Christmas's school-house, across the Gardenmorris road, to Pembrokestown, by the house, by Butlerstown, to near Mount Congreve, then to the right, and killed him in the open at Old Court. This was eighteen miles, time one hour and forty minutes. We had scores of fine runs over the Waterford country, from Ballydurn, Rathgormack, Kilmoylan, Sir Edward Kennedy's plantations, and others, but it would take me a month to tell you of them.

What sort of country have we? We have every sort. The Welsh hills (Lord Bessborough's property), and Pembrokstown, are as bad as can be, rocks and stones everywhere; hounds have a fair, but horses a very bad chance of going over it. They are fine wild places, and the Welsh hills provide us with wild, hardy, good foxes, and are well cared for by Lord Bessborough's tenantry. The same can't be said, however, for Pembrokestown, for that is the only part of this country in which a fox is not well treated, although as fine a sportsman as ever lived has property there, Mr. Congreve Rogers. ITe find in his 
cover generally, and nothing gives him such pleasure as when we do; and though he does all he can to have the foxes preserved, he is not supported as he ought to be.

The Kilmacthomas country, which we call that which takes in Ballydurn, Kilmoylan, Currabaha, Woodhouse, \&c., is an extent of some ten miles square, and is as fine a hunting country as ever was ridden over : big, safe fences, and good galloping, the fields all grass, in some places rather small, and a bog now and again comes in the way. The Rathgormack country is what is from Croghawn Hill to Gurteen, and is just like the Kilmacthomas. Some of the Gaultier district is very good-some middling enough-but his lordship does not hunt that portion very often. If he put a gorse cover somewhere near Belle Lake, and looked after the Dunmore and Lesalan covers, this would afford him another day a week, and he would have good sport down there, as foxes are plenty, and well preserved by Sir Robert Paul, Mr. Power of Faithlegg, and others. The portions he got from the Tipperarys and the Kilkennys (the latter the Ross country), are the cream of our "happy hunting-grounds." Nothing can beat them for fair play to hounds and for trying what the men and horses are made of : nearly all grass, and big, safe, double fences. The country from Carrigtruss, say to Knockbrack, is " much of a muchness;" very fair, with small fences, mostly walls; but some bogs are to be found there. Taking the Curraghmore country "all in all" it is a very good one, and most certainly, is as good scenting a one as any in Ireland. Very little plough, not a strand of wire (except on the railways); and we have every description 
of fence to negotiate, walls, double and single fences (some of the latter faced with stone, and straight as a house), water and timber occasionally, but not often. Whenever you want a horse, if youl get one that has gone straight over our country, you may be certain of a safe conveyance over any country in Great Britain.

We have not many big woodlands except Curraghmore, Kilcash, and Newtown; Coolnamuck and Churchtown used to be, but the trees have been cut down; and we have some of the finest, oldest, and prettiest gorses in Ireland. What lovely covers are those of Carrigtruss and Knockbrack; strongholds of foxes for the last century. Carrigeen, Tubrid, Wilmer, Ballydurn, Rathgormack, Ballyneil, Kilmoylan, and Kilmacthomas (a bad scenting cover). Then the new gorses his lordship planted, viz., Earlies Gorse, Weatherstown, Rochestown, Mullinahone, and surely we must not forget classic old Tory Hill, which is a land-mark for miles around, and which held many good foxes and afforded sport for years and years past. By way of parenthesis, I will tell you what old Sir John Power said of Tory Hill once. He was a supporter of the Whigs, and one day, after a severe run, the hounds were running up its steep side, and Sir John found his horse was very beaten; He got off, and leading him up, he was heard to say, "Damn you, Tory, I wish you and every other Tory were levelled !" Then we have those grand nurseries for foxes in summer, and from which we have many a fine run in winter:-Clonassey, Carrig-a-tubrid, Dowling, Corbally, Newtown, and Kilcash; and in the lowlands you see Bessborough, Belleisle, Cregg, 
Castletown; and in the distance Mount Neil, with Mount Congreve at the other side of the Suir ; this latter, perhaps for its size, is the best of all, thanks to the care Mr. Congreve takes of it. Gardenmorris, too, on the Waterford side, is a rare place for sheltering our game; so also are Faithlegg and Ballinamona.

What about the men who hunt with his Lordship and those who hunted with his uncle and Briscoe? Well, I will tell you as well as I can recollect, but I don't like mentioning names; however, I dare say they won't be very angry at my doing so, even though you put them in this book of yours.

The best welters I ever saw riding to hounds, in their day, were the late Lord Henry, William Power of Seafield, the present Wray Pallisser, and Johnny Webb (the bruising constabulary officer). These men all rode over sixteen stone-but none of us could beat them, either in a quick spin or a long hunting run. With the exception of Lord Waterford, they all rode to sell as well as for sport-and very good cattle they had. The late Sir John Power was as good a man as ever rode over the Curraghmore country. Tom Lalor of Cregg could never be beaten. He is a feather weight, and always rode well-bred horses. He knew nothing, and cared less about hounds. All he cared for was a brilliant gallop, no matter how long or how difficult the country might be: but he never did harm, and knew well how to ride to hounds as they should be ridden to.

Billy Mulcahy was a very hard man with good hands, but he was always over-riding the hounds, and was very jealous. They called him "Quarry 
Mulcahy," from his having ridden into a quarry, killing his horse, and nearly killing himself.

Congreve Fleming, then living at Greenville, was a brilliant man, particularly on a young horse; his hands and seat were perfect. What good company he was! always cracking jokes, and never could refuse a pleasant convivial meeting. He was, and is, as good sort as ever lived, and so was his father, the Captain. His son Arthur was also a fine horseman. Poor fellow! he died some years ago.

David, George, and Fred Malcomson were as good a lot of brothers as could be found. In fact, I never knew three of a family I would not match them against for all I was worth. They loved hunting, were thorough sportsmen, and to their liberal subscriptions and donations were we indebted to keeping the hounds up for many years of Briscoe's mastership. Their hearts were kind, and their pockets open to any subscription. David and Fred are, alas! gone, but George is well and hearty. May he long be so.

Larry Dobbyn was a wonderful man to go, too. Indeed he ought to have been classed with the welters, as he certainly rode fifteen stone; and what an active fellow he was! He would jump off his horse coming to a big fence, jump it with him, and into the saddle at the other side without losing a length.

The late Earl of Huntingdon was a very hard man to hounds, and had a wonderfully quick eye. On old Jason he couldn't be beaten. He was the jolliest and heartiest of men. The old Marquis used always call him "the Peer."

Sir Robert Paul was a fine horseman, and keen sportsman; he kept nothing but rare, good horses. Bracelet, 
Jack Sheppard, Regalia, and many others often carried him in the first flight. He was very fond of tandem, and drove well. In fact, whatever Sir Robert does he does well. He has two sons, William and Robert, who bid fair to equal him. Both are tip-top representatives of a worthy sire, and up to every kind of sport.

John Walshe of Fanningstown was very fond of hunting, and knew every inch of the country; and no matter what line or what distance a run might be, he was sure to be up at the finish, though of late years he kept to the roads. He had a nice pack of harriers, which showed good sport after the fur, while they prevented the foxes lying out. They were hunted by that good sportsman, Ned Briscoe of Harristown.

John de Montmorency of Castlemorris, was a "true blue" sportsman, and one of the best landlords and most useful country gentlemen in Ireland.

Mr. Edward Roberts, the respected agent for the Curraghmore estates for the last three generations, used in old times to go well. He was a rare judge of a horse. No pleasanter evening can a man spend than while listening to him recounting "scenes of long ago," of men of his day. A finer type of "a real old Irish gentleman" than Mr. Roberts is not to be found now-a-days, and may he long live to continue so.

His son Arthur, when on a horse he knew, went well. So did Johnny Medlycott, but he was a better and bolder horseman. It was no joke to beat either of these men when mounted on Riddle and Playboy.

James Anderson, of Gracedieu was of the type, of 
Mr. Montmorency, of Castlemorris - a real sportsman and useful country gentleman. He, as well as Sir Robert Paul, has sons who emulate their father's goodness both in and off the field.

John Jones, of Mullinabro, was, in his day, a clinker. Nothing would stop him, and to this moment no one is fonder of the sport or comes out oftener, and generally on a young one, but always on a well-bred one. He, too, has sons who go well and straight. What good stories I have heard from him, and rare toasts too!

Harry Sargent and Joe Strangman were very constant men with these hounds, and always went well. Very few good runs can be recorded on days they were out that their names don't appear in. Sargent had a wonderful horse he called "the Squire." He carried him for fifteen or sixteen seasons. When the Squire was in his prime, and with a bay horse he had called Larry, and a gray called Mainsail, very few could beat Sargent. Strangman had very good horses in the Wizard, Bretby, Volunteer, and Brunette. They called him the "bearded flying Quaker." He has been IIon. Sec. to the Hunt for many years, and no one could take more painsthan he does with the onerous duties connected therewith, in testimony of which the members presented him with a costly service of silver some years ago at a hunt dinner.

Henry Jephson was a wonderful, hard, and good man in Lord Henry's time. He was the best of good fellows, and liked by all. He was up to every sort of sport, and was called "Sporting Harry." Lord Waterford always had him with him. He was also called "Lord Waterford's man Friday."

Congreve Rogers had good hands and seat, 
always rode well-bred horses, was and is a thorough sportsman in every sense of the word. He was always well turned out, and a good man between the flags long ago when we had the races in Tramore. Nany a time I saw him cheered a winner to the scales. Glascott of Alderton, and Lambert of Carnagh, were constant attendants from Wexford; no men went straighter or better than they.

Dick and Tom Morris, Joe Rivers, Ned Courtenay, Ned Clibborn, Clemt. Sadlier, John Waring, Charley Gregory, Doctor O'Ryan, Billy Johnson, were also good men and true; there were many others, but time and space do not admit of any reference to them.

The men who go well now with the Curraghmores are: Capt. Slacke (no better man in the world to ride a hunt, whether mounter on a well-trained or a green one, it is all alike to him), Lords Charles, Marcus, and William Beresford, when at home, Tom Lalor, Willy and Bob Paul, Willy Anderson, the young Jones of Mullinabro', the young Courtenays, Spencer, Joe Strangman, Harry Sargent, Raymond and Arnold de la Poer, Perry of Woodroofe, Sir Richard Power, Ralph Bunbury, Hugh Baker, the Mansfields of Lanscape, Brent Neville, who always has a good-looking horse. Jimmy Dobbyn of Tipperary, Louis Strangman, and his kinsmen Johnny and Sam, Fred Power of Bellvue, John Fanning, John Bell of Clonmel, and others. The present Lord Huntingdon, when living at Whitechurch, used to bring down large contingents from the WVest, the Humbles, Odell, Maxwell, Dick Roberts, and others, and they all went well with us. We have also many ladies, married and unmarried, who ride remarkably well to hounds; but I shall not 
tell their names, for fear the ruling passion of the sex, jealousy, might be aroused. We are always glad to see them out, and showing us the way too. Let us toast them: "The Ladies, God bless them!"

The number at the meets of the Curragh more averages about sixty; and for a united, orderly, and sporting field of good fellows, no hunt can boast of a better lot.

We have many men in our country who, though not fox-hunters themselves, preserve their covers for Lord Waterford, and who love the sport just as much as he does himself. Notably among those I must name: Mr. Congreve of Mount Congreve, Mr. O'Shee of Gardenmorris, Sir Robert Paul of Ballyglan (he has not hunted for someyears), Capt. Dawson of Blenheim, and Mr. Power of Faithlegg, who, though he keeps harriers, seldom comes out with the Curraghmore. Lord Bessborough is one of the very best supporters, and when at home, a constant attendant in the field, as is Lady Bessborough. Capt. Armstrong of Ballydavid, Hon. Dudley Fortescue, Mr. Christmas of Whitfield, Mr. Carew of Ballinamona, Mr. Sweetman of Annaghs, Dr. George Mackesy, who owns Lucy's Rock and Glenmore covers, Mr. Bowers of Clogga, Ned Briscoe, Henry Bowers, Mr. Elliot of Rathcurbey, Ambrose Lambert, and others, do all in their power to preserve the wily tribe. Then such a good lot of Farmers as we have; one and all preserve the foxes; never object to our doing a bit of damage to their fences or fields; never put up wire; and do not often object to an odd hen or a turkey's disappearance. It is such men as belong to the latter class fox-hunting has to look to for its true support, and blessed is the Curraghmore in having such a supply of them. 
There is not a selfish feather-game preserver, nor a single grumbling farmer in the county.

The present Lord Waterford was born in $\mathbf{1} 844$, and succeeded to the title as fifth marquis, in November, 1866. The marquisate is not of a very ancient date, but the Barony of De la Poer is, as it was created in 1375 , and to this as well as to other titles his lordship succeeded; but as I am a bad chronologist, I must refer you to Burke if you desire to know more on this head. He was educated at Eton, and in 1862 , he got his commission in the First Life Guards. He represented the county of Vaterford in parliament as Lord Tyrone for some time before his elevation to the House of Lords. While in the Guards he evinced a strong liking for a soldier's life, and soon got imbued with that love of order and discipline which characterises and qualifies him, as it eminently does, for the due regulation of his gigantic and princely establishment. He first married Florence Grosvenor, second daughter of the late Major Rowley, and niece to Sir Charles Rowley, Bart. She died in 1873 , and in 1874 he married the present Marchioness, Blanche, only daughter of the Duke of Beaufort. As already mentioned, he took up the Curraghmore from the county in 1870 . He gave Duke the horn, and under him put G. Hagar, as first whip, and Billy Quin as second; Hagar was succeeded the next season by Dan Ryan, son of old Johnny Ryan the former huntsman, and now he has Arthur Wilson, and John Crowley in their places. Lord Waterford's turn-out of his hunting establishment is about as perfect and as workmanlike as it can possibly be. The men have that "smart" appearance that none 
but a smart master can enforce; and though their boots, breeches, coats, bridles, saddles, and general equipments are such as do credit to his lordship's tradesmen, and fit as well as the neatest Meltonians, no one can mistake their being servants. Each has two horses out each day, and their mounts are as good as money can procure, for his lordship never buys what is usually called "servant's horses," but gets for his men animals that will leave them no excuse for not doing their business properly. The horses his lordship rides himself are of the weight-carrying sort, as he rides sixteen stone; but they are wellbred and good-looking, and under his weight can gallop and live through any run. His four-in-hand, or mail phaeton and pair, as he drives up to the meet, are such as would call for approval from the pen of the veriest critic on the turns-out of "the Row," on a Saturday in May. Lady Waterford attends the meets as well as her husband, and to see her on her horse whether riding along to covert or sailing beside the pack over a country during a brilliant run, is, indeed, to see a female centaur! She can, indeed, ride to hounds. Nothing can exceed Lord and Lady Waterford's courtesy in the field; they are affable to all. His lordship rides with the pluck and determination characteristic of every Beresford; and as his horses are very good, and brought out in first-rate condition, he lives through every run, but he has not yet acquired the fine hands and seat which his uncle had and which his younger brothers, even the sailor, Lord Charles, have. They are all accomplished horsemen, and no doubt before long he will have attained these attributes. As I said before 
he is an undoubted good judge of both horses and hounds; he is a first-rate shot, but neither a fisherman, courser, nor yachtsman; nor is he fond of racing. The Dowager Marchioness is perhaps as popular a lady with our hunt as there existsin any hunt in Great Britain. She too goes over the country in the most artistic style, though, strange to say, it is only within the last few years she has taken to cross the country. She is also most genial and kind in her manner to everyone.

Love of fox-hunting is, no doubt, a very great desideratum in a nobleman in the high position Lord Waterford is; but society demands other and more important duties to be performed by a man so circumstanced, and in them my subject shines brightly.

$\mathrm{He}^{-}$is a landlord possessed of immense landed, property, and he has made himself personally acquainted with every tenant on his estates: he knows their wants, and sees them satisfied without distinction of creed or politics. In the management of the business details of the several establishments within the confines of his vast demesne-the farm-yard, the farming, the woods and plantings, the stables, kennels, and all else-he takes the greatest personal interest, and superintends the working of all, and has all regulated with that precision as regards detail and accounts as would give credit to Hardy and Townsend. $\mathrm{He}$ has established a factory in Kilmacthomas, for the making of the famous "Waterford Frieze," in which are employed from 200 to 300 hands; and by his sound sense he has made it a very money-making concern.

Lady Waterford assists her noble spouse in all these laudable undertakings, and has instituted in- 
dustrial schools, over which she personally presides, and she visits the sick and ministers to their wants in the most charitable manner.

Duke was a very good whipper, and learned much under Briscoe; and since he has been promoted to the post of huntsman he has shown that he can fill that position equally well. He rides well, he lets his hounds work for themselves, and never interferes with them until it is necessary, and when he does he seldom disappoints them. He is most persevering, and never gives up while the least chance remains of accounting for his fox. The only fault I know him possessed of as a workman is, he sometimes draws his coverts too quickly, and leaves a fox after him if he lies close.

Billy Quin, and Dan Ryan, were very good whips under him, and he now has the making of a good man in Arthur Wilson; and Johnny Crowley is a well behaved boy too.

Johnny Ryan, his lordship's second horseman, is no relative to old Johnny the huntsman. He has been in the service of the Curraghmore family for a long time, having been taken up by Lord Henry at the Curragh many years ago.

Lord Henry made him his flat and steeplechase jockey, and he steered for him to victory many a mount. He has a most perfect seat and hands, and no man can "make" a young one better than he can, nor does a master possess a more valuable servant in his way than Lord Waterford possesses in Johnny Ryan.

It was a rare sight long ago to see "old Johnny" the huntsman handle the hounds, and how he used to 
ride to them ! I think he had the prettiest seat on a horse I ever saw. I have heard that he was very like Davis, the Royal huntsman. He never seemed in a hurry; no matter what pace the hounds were goingat he was always with them. He had but two touches for his horn, one a long, single blast to bring them to him, the other a "tot, tot, tot, a-tot-a-tot," which made our hearts jump and every hound fly to him, for hearing that thrilling blast made us all know a fox was away. I never heard a man blow a horn better than he, but it was always in its case except when absolutely required. He told me a curious story once, but strange as it is it is a fact. Lord Henry sent a draft of hounds to a gentleman in the county Clare many years ago ; they were driven in the van to Fiddown station, five miles from the kennels, sent by train to Limerick, and thence up the Shannon by boat, and some ten miles into the county Clare, to the gentleman's residence. In ten days' time one of the draft (a bitch, I forget her name) arrived at the Curraghmore kennels, having found her way back by herself.

Like all old establishments of the kind, Curraghmore has its many retainers in the persons of old servants and workmen. Paddy and Billy Quin in the stables for the last forty years; Harney, the gamekeeper, just as long; about twenty old chaps who have grown double in the service of the gardens, \&c. Then old Fleming, Johnny Bowers, Clancy and Whittle, earth-stoppers for very many years. Then, of more recent date, Ambrose Power and Frank Bowers, two capital earth-warners for the Waterford and Kilkenny sides. Talking of earth-stopping reminds 
me of "Tommy Knockmore;" he has been in care of Killeen since it was planted, and there never was a better keeper; he would always have a litter in the cover though it is not an acre in extent; and no matter how scant the gorse might be, if there was a fox within five miles of it, he would have him there when the hounds drew it. He told me the dodge he practised, which is a most efficacious one, though, perhaps, not particularly considerate to his neighbouring keepers. However, it was not done by " bagging."

I ought to have said a word about our Hunt Steeplechases. They were established by the present Marquis in 1870 , and used to be run over a course in the Ballydurn country; but that not being convenient, the venue was changed to Williamstown, two miles from Waterford, where they have since been held. A beautiful course is now laid out there, and which is a natural one: none of your artificial cock-pits, which you see all over the country now. The stand-houses and paddocks are commodious; and, after Punchestown, the meeting has no superior in Ireland: though it has not the costly appointments of Cork, Baldoyle, or Fairy House. The different races are all called after our principal fox coverts, and it was this meeting that first revived the old red-coat races of long ago, and which are now so popular in Ireland. Mr. Harry Sargent, assisted by Captain Slacke, has always managed these races; and, if we believe the newspapers, he has managed them well ; but it was a "labour of love" to him, and he understood it, and would not undertake the management unless he was allowed to do it properly, which he is by Lord Waterford, who allows him almost a carte blanche to do as he deems best for 
its success. His lordship cares little for racing as a rule, but takes great interest in the Hunt Races, which he instituted for the amusement of the farmers, and as a small return to them for the support they give him in the hunting.

I omitted to mention that when Lord Huntingdon (then Lord Hastings) gave up the Dungarvan and Whitechurch country to take his present country, Lord Waterford took it; but it was too far away and inconvenient, so he gave it up after a year or two.

Curraghmore is stituated near Portlaw, a small village, ten miles from Waterford, and one of the prettiest in Ireland, owing to the enterprise and employment given by that princely firm, Messrs. Malcomson Brothers, whose headquarters are in the village, and where they employ some 2,000 hands daily.

The Portlaw entrance to Curraghmore is not exactly so imposing as you might expect, and for that matter, every entrance to it is beneath it. However, once within the walls, one very soon forgets the gateways, for on all sides we see that which gladdens the eye of the lover of the picturesque and grand; but from the meaning of the word Curraghmore we imagine we are to see vast plains stretching away on all sides. No such thing. The hills and valleys are mostly covered with woods, and it is only in the race-course and large sheep-walk fronting the pleasure-grounds that we see large enclosures. It is, however, those which gave origin to the name, for it was only the portion of the present demesne which lies on the Carrick side of the Clodiagh, that always belonged to the Curraghmore family, the woods of Portlaw, Baylock, and Darrigal being of recent acquisition by purchase from the Duckett and Medly- 
cott families. These woods are truly magnificent, and covering, as they do, to the top, the undulating hills, and being principally oak, the foliage from a distance gives you the idea they are heath-covered mountains. The River Clodiagh flows through the demesne, from Lowry's Bridge to Portlaw, and a more beautiful valley than it is I don't think exists in Wicklow. The view to be had from Clonegam Hill, near the little churchyard, is very grand and expansive, commanding the greater portion of the demesne, with miles of country around, and the Comeragh mountains in the distance, while underneath we have the mansion and the courtyard, of which we get almost a bird'seye view.

The gardens are nothing to speak of, nor are the pleasure-grounds, though, of course, the best of fruits and flowers are grown in them. The vast de. mesne of Curraghmore, containing, as it does, 4,000 acres within the wall, and 3,000 acres in the Portlaw and Baylock woods, has nothing artificial to boast of. It is all naturally grand and beautiful. The house is built at one end of the extensive courtyard, and is of modest exterior, though within the last few years the present Marquis has done much to change its appearance, and it is now vastly improved. For the last thirty years the different heads of the family have been getting plans and specifications for its remodeling and doing up, but none pleased until the present Marquis got the aid of Mr. Samuel Roberts, the well-known and able friend of art, of the Board of Works. This gentleman furnished the necessary plans, and under him was the work done; and now the old house looks like a modern one, built for comfort 
rather than beauty. The inside is exceedingly well and comfortably laid out, but not to the same extent of magnificence and show that one sees in houses of other noblemen of Lord Waterford's position. The stables form each side of the courtyard, and they, like the house, are built for comfort, use, and health, rather than for showing off the new inventions of stable furniture and architecture. They contain boxes for about thirty horses; ranges of stalls for as many more; very extensive harness and saddle-rooms and coachhouses. To the right as you enter the court are two long ranges of box-stalls, built at the rear of those forming the court ; in these are the servants' and young horses, and in which is accommodation for some fifty. The farmyard has the same characteristic, all for utility, and resistance of wear and tear.

The pointer and setter kennels adjoin, of course, old Harney the gamekeeper's house, and are very extensive, and near them is the pheasantry; but his lordship does not care much for the long tails, and has but few.

A stroll of a mile along the banks of the Clodiagh brings us to the kennels. They are situated close to the river, with a southern aspect. They have eight or ten separate lodging-houses, with a large feedinghouse and drafting-yard in the centre. In front there is a large enclosed paddock for airing the hounds after feeding, and in this lies the only defect in them. It is on a steep hill-side, with a fall to the kennels; but as the drainage is good, no bad effects are found, and the hounds never suffer from kennel lameness. Outside this is another large paddock, in which the brood bitches lodge in wooden huts when they have their puppies. 
At the rear of the kennels, or the front of them, if you chose to call it so, is the huntsman's house, which his lordship has lately added to considerably (as Duke and his wife are remarkably good subjects to the Queen, and have added to the population some eight or ten children). Nothing can exceed the comfort and design of all. It requires only to be seen to be appreciated. The kennels contain from fifty to sixty couple of entered hounds, and about twenty or thirty couple are put forward yearly - the drafts being Duke's perquisites, and are bespoken years beforehand.

Lady Catherine Beresford got erected a coneshaped house in one of the pleasure-grounds, the inside of which she covered, in the most beautifully-arranged designs, with shells of all kinds. It took her a great many years to complete the task, all of which she did with her own hands, and finished in 1651 . In the centre of it is now a white marble statue of her ladyship. On a hot day in summer a visit to this grotto, as I may call it, is most enjoyable, as the cool air is delicious, and an hour or two can be agreeably spent in it, admiring the handiwork and taste displayed by the lady, particularly if you have a lady companion with you at the time.

The little churchyard on the top of Clonegam hill is the resting-place of the dead worthies of the house of Beresford for many generations. In it are also laid the members of the Medlycott and other families of distinction. Inside the little church are magnificent full-length marble figures of Lords Henry and John, the third and fourth Marquises, and in a niche, expressly cut out for the purpose, the finest work ever executed by the celebrated Boepm is laid. It is 
the marble effigy of Lady Florence, the present Marquis' first wife, with her infant clild reposing in her arms. It is of the finest Italian marble, and is so laid out, that wherever the sun shines it reflects its rays.

I know no place where a sportsman who loves to see a sporting establishment can enjoy himself more than he can at Curraghmore, which, by the kindness of Lord Waterford, and the universal civility he receives from his employées, he can do with ease and comfort, for though he can't see artistic beauty, he will see natural grandeur, and one of the most extensive and best-managed sporting establishments possessed by any nobleman in the Kingdom.

Now I have given you all the information in my power, and will sing you a song of the Curraghmore Hunt.

\section{THE CURRAGHMORE HUNT.}

An ADDRESS from the Annefield Fox, which gave the Four Celebrated Runs during the Seasons of $186 \mathrm{I}-2$.

I WAGGED my brush the other day When everything was still,

I am a Fox, my fame is known, I live on Annefield Hill.

And now, ye brother Foxes all, Come listen to my song,

I'll tell you about a Pack of Hounds, And how they go along.

I've given them four grand runs, * And I'll give them many more, For I'm the boy to go the pace From the Hounds of Curraghmore.

* i 7 th Dec., 1861-1 hour and 40 minutes. 28th Jan., 1862-4 hours and 5 minutes, 31 miles. 24th March, 1862-1 hour and 25 minutes. Iith April, $1862-2$ hours and 5 minutes. 
Of one, ye Foxes, must beware, 'Tis Briscoe, he's the Master, And when ye see him on his grey, Your brushes whisk, and go the faster.

You'll easily know him by a fact, Which between us I will mention, He pays the Ladies at the Meet Remarkable attention.

For Ladies patronise this Hunt, Rich, poor, the great, and small, And very much delighted are When a fellow gets a fall.

There's Johnny Ryan, * on old "Wall," He looks as fresh as paint,

I do not like to look at him, For fear that I should faint.

Avoid him, then, ye Foxes all, As thro' the cover he crushes;

And if ye will not take advice, Ye'll surely lose your brushes.

Then Duke, $\uparrow$ that bloody-minded whip, Oh! how he makes me run,

I wish that he would stay at home With his wife, and mind his son.

But there is one ye must respect With love and adoration, 'Tis Parson Gregory that I mean, A Friend to all our nation.

The Primate, just before he died, On that eventful day Appointed him our race to shrive, And o'er out corpse to pray.

His duty is so well performed Your mind may be at rest; Where'er you fall, he will be there, You'll not die unconfessed. 
Next on my list's a little man, His name is Tommy Lalor, And on his little head he wears A hat, to make him taller.

But if he's small, his heart is great, He never is so happy As when, by doing all he can, He beats the bold Mulcahy.

Mulcahy tries by might and main To beat the gallant Tom, And if he only does succeed He roars and rides along.

A grudge he owes me since last year, * And if it is his luck

He swears he'll eat me, and I'm sure His mouth is large enough.

Now mark the man's good-humoured face, Who with commanding frown

Replies to fellows' "How do you do ?" With "Please, sir, half-a-crown."

He rides a mare, her colour's bay, Her temper's very hot,

He blesses her, and never swears, And his name is Medlycott.

George Malcomson next comes in sight, A portly man is he,

Though heavy his stern, his heart is light As ever a man's can be:

Congy Fleming on "Magpie" sits

In a very seedy coat,

Ah! he's the lad to drain a flask, Or tell _a pleasant joke.

But who's the hammerer on the road? I do not know from Adam, By the way he rides, I'm sure he is Some relative of Macadam.

Ah! now I see, it is John Walshe, To tell you's only fair, You need not fear him any more, He's taken to hunt the hare.

* William Mulcahy's mare died after the run of the 28 th January, 1862. 
There's David and Fred Malcomson,

True sportsmen to the bone,

Who wives have got, and children too,

But won't be kept at home.

Most hunts can boast of curious men, Parson, Methodist, or Shaker,

But who can boast what this hunt canA bearded, flying Quaker!*

A sportsman comes from Wexford side A forward riding man;

When Glascott's going with the hounds Oh! catch him then who can.

Black-coated Lambert well can go, And to the front will paddle, But he'd look better if he kept $H$ is hand from off the saddle.

Then Butler rides to the covert side, That amorous gay young Peeler, He rattles on, and often gets A most tremendous squeeler.

A clicking noise I thought I heard, 'Tis Rivers on the grey,

He ticks so hard, I'm sure his horse Can tell the time of day. $\dagger$

From Waterford, Harry Sargent comes, Right forward he will race

And better still he seems to go

Since he's got a hairy face. $f$

The Captain $\S$ fresh from foreign parts, From fighting and hard knocks,

"Ram Rusty" spurs, and much prefers At home to hunt the Fox.

Each hair upon my body stands, I hear some ominous sounds, Good-bye, ye foxes, I am off, I just can see the hounds.

* Joseph Strangman, a "first flight" man.

† He has a habit of always "click, clicking," to his horse.

¥He let his beard and mustache grow this season.

$\$$ Capt. Briscoe, eldest son of Henry Briscoe, the Master. 
THE CURRAGHMORE HOUNDS.

The pace they go it makes me shake, My blood begins to frizzle,

My verse is clipped, my wind I want,

For for'ad I must mizzle.

Annefield Covert, Ozoning, Co. Kilkenny,

February, 1863.

One toast more: "Fox hunting and the Curraghmore." Good night. I'm off to Bedfordshire. 


\section{CHAPTER III.}

THE WARD UNION HOUNDS.

THE mention of the "Wards" recalls to the minds of many sportsmen, old and young, recollections of pleasant scenes, extraordinary feats, and happy hunting grounds. Their fame is more than European. In the new world as well as in the old they are spoken of with enthusiasm; and many there are whose destiny has placed them beneath the fierce glare of an Indian sun who owe some of their happiest hours to the "Wards."

No wonder that Dublin includes so many sportsmen, and sportswomen too, amongst its inhabitants. They may, and do call you dirty Dublin, but who separates that epithet from one of endearment belonging to no other urban agglomeration? Despite Anna Liffey, a quarrelsome corporation, and fierce party spirit, and the other ills to which your inhabitants have long been heirs, you are always "dear" to your sons and daughters. There are amongst the inhabitants many merchants, and merchant princes too, who are ardent votaries of the chase. There is a regular influx of Nimrods during the winter months, and the citizens include many patrons of the turf, the chase, cricketers, rinkers, and pursuers of tribes feathered and finny. A sportsman, whether possessed of moderate or ample means, could not reside in a city with more 
facilities for enjoyment. If a lover of foxhunting, he frequently has an opportunity of hunting with the Kildare, Meath, and Louth hounds; and the "Wards" meet three times a week at a convenient rendezvous.

If the harriers have attractions for him, Mr. Brooke, of Summerton, Castleknock, has a good pack, about 12 couple, 18 inches high, and he invariable lays the venue for their trysts near the capital. Mr. Thomas Turbett keeps a nice pack of beagles at Finglass; and by-the-by I was near forgetting to mention that a few gentlemen keep a pack of musical "currant jelly" dogs in that neighbourhood also. Those fond of shooting will find game in abundance at no great distance ; lovers of the leash, too, will find their wants amply provided for; and disciples of Izaak Walton can kill trout or salmon within a few miles of the metropolis. The "Phœnix" affords ample opportunities for the training of flat and steeplechase horses or hunters, and it is-par excellence-the finest park in the world-the scenery around it is charming; and on a fine summer's morning, when the troops are being reviewed, and the sons of Mars are marching, while the bands discourse sweet music, I know of no place of its kind so attractive and picturesque.

I shall now endeavour to give a history of the Ward Union Hunt:-

The country over which they hunt is all that a hunting man could desire; most of the fences require a deal of "doing," but a good, bold fencer will get over them without much difficulty. The "going" is generally good; indeed the committee, with a wis- 
dom and thoughtfulness worthy of commendation, seldom allow the hounds to be taken out when such is not the case, as they have a kindly regard for the interests of the landowners: there can be no better proof of this than the entende cordiale which exists between the hunting men and the farmers of the district. Many "crack" men from different parts of England have often hunted over the country; old Meltonians, Leicestershire celebrities, followers of the York and Ainsty, and " first-flight" Pytchley men too. "Many a time and oft" hard riding men from the shires and wolds have endeavoured to cut down the Ward men.

\section{"Hard riding swells from Leicestershire, \\ Northamptonshire, and Twickenham, Have tried to give the Ward Hunt men A licking that would sicken 'em,"}

but didn't; but they ever bestowed the highest praise on the country and the pack. It is the pace that kills; and those hounds can and do go fast enough to satisfy the greatest "bruiser," or most reputed flyer.

The " fields" generally include desperate cornets, reckless as middies, crack cavalry men, and steeplechase riders of renown.

In I 828-9 there were two packs, the Dubber and the Hollywood, kept in the Dublin country, and hunted over what is now the Ward Hunt country. In 1830 , the packs were amalgamated, and kept by Mr. Ger. rard, of the Bay, and called the "Wards." Captain John Stanley, son of Sir Thomas Stanley, of Hooton Hall, Cheshire, succeeded Mr. Gerrard as master: he kept them for two seasons; and in $1836 \mathrm{Mr}$. Peter 
Alley, of New Park, took them. Up to that period they used to hunt "bag"-foxes, but Mr. Alley got a number of fallow-deer, gave up fox-hunting, and after a few years red-deer were procured.

The late Lord Howth, in I840, brought over Mr. Broadley's Staghounds from Leamington, and kept them, with a subscription from the military, till Lady Howth died in 1842 ; he then sold them to the Dublin Garrison, and they were known as the Garrison Hounds. A first-rate pack they were-indeed I have heard good judges say that they were the fastest they ever saw.

Captain Forrester hunted them for a few years, and then they were presided over by one of the best horsemen that ever sat in a saddle, Captain Armit, who rode the winners of many important races, and was a great favourite. He was succeeded by his brother soldier, the Hon. William Hutchinson, who with his brother, the late Lord Donoughmore, and his cousin, Colonel (then Captain) Richard Bernard, and other relatives, made up a family party not rivalled before or since. Their "larks" are still fresh in the memory of many, and the recountal of "Dear Dickies'," or "Bright Billy's" doings, would fill a volume by itself. The latter was a sportsman in the truest sense of the word, and a braver never won or wore a Victoria Cross. (He tried hard to win it.) He was assisted in the field by Captain Richard Bernard-in those days the luckiest and, perhaps, the pluckiest of all contemporary horsemen. The sport during their reign was splendid. In 1854, the Crimean war broke out, and several of those who hunted with and supported the Garrison hounds 
were ordered off to take part in that sanguinary struggle. The scarlet hunting-coat was laid aside, and the uniform of her Majesty's service donned instead, by many who had worshipped faithfully at the shrine of Diana, and who were called upon now to pay tribute to another deity. Alas! several of those brave fellows never returned to Ireland or wore hunting costume again. No, in Russian soil they,

"Their warfare o'er,

Sleep the sleep that knows no breaking,

Dream of battle-fields no more,

Days of danger, nights of waking."

The Duke of Wellington, the "great Duke," always preferred hunting men for soldiers; and, no doubt, he was right, there are none so bold, and his judgment was borne out at Waterloo. Many of those who had hunted with the Garrison hounds charged as fearlessly into the jaws of death, on the heights of Alma, in the valley of Inkerman, and on the plains of Bala. clava, as they did the "yawners" they often sailed over in the Kilrue, Fairyhouse, Dunshaughlin, and Ashbourne districts, when they participated in the peaceful mimic warfare of the chase over that country which is so admirably adapted for a hunting campaign. Captain W. Hutchinson never returned to carry the hunting horn, poor fellow. He sleeps by the blue waters of the Bosphorus, on whose bosom our then undreamed-of ironclads rock to-day awaiting, perhaps, the call to war. He died of camp fever, regretted by an army and all Ireland. Richard Bernard has been more fortunate than his cousin; he has had many a good days' hunting since, gained new laurels on the turf, and is now a Colonel of his county 
regiment, Deputy-Ranger of the Curragh, and the member of our "Irish household," which best connects us with the "pleasant part."

When the war broke out, the military proposed to give the Ward managers $£^{200}$ per annum, if they would give an extra day each week (the Wards were then a bi-weekly pack); the offer was gladly accepted, and the arrangement is still in force, albeit the annual subscription is a somewhat fluctuating quantity. Mr. Peter Alley kept the hounds till $\mathrm{I}_{86} 3$, and at his death his brother Charles became master, and held the title for a year, when the delicate state of his health obliged him to resign. The Messrs. Alley deserve great praise for the manner in which they acted during their reign as masters of the "Wards."

In 1864 , the pack was handed over to a Committee, and Captain Montgomery, late of the $5^{\text {th }}$ Dragoon Guards, was appointed master. He resigned in $\mathbf{I} 866$, and a Committee of three have managed them ever since with great success. On Mondays the meet is usually some miles distant from the city, but, thanks to the liberality of the managers and directors of the Midland Great Western line, horses and their owners are conveyed by special train to the nearest station. The trains start from and return to the Broadstone at convenient hours, and horse, owner, - and servants are brought down and back for the moderate tariff of ros. The owner, of course, travels first class. If other lines followed the example shown them by the executive of this one, they would be "wise in their generation," and confer a benefit on the shareholders, hunting men, and a large section of the community. In a financial point of view, as well as in 
every other, the Ward Union Hunt is in a very flourishing condition; and the trio of efficient officials who comprise the Committee deserve the highest praise for their industry and ability so plainly shown by the success they have merited and achieved in the management entrusted to them. I have before me the balance-sheet for the year ending 1876 , and the manner in which the Committee have "financed" the concern speaks volumes in favour of them.

I find I 2 I names of subscribers of $£ 5$ or upwards included in the list of members and subscribers. The sum total amounted to $£ 75^{2}$.

I take the following extract from the Committee's circular of 19th August, I875:--" The average balance to credit of account on each ist of May, from I 864 to 1874 , has been $£ 230$. The balance, ist of May, I874, was $£ 2158 s .4 d$. The balance, ist of May, 1875 , to DEBIT was $f_{21}$ I $6 s .9 d$. It will be seen from those figures, that to enable the Committee to carry on the establishment as heretofore, there should be on the Ist of May in each year a balance of, say $£_{200}$ in their hands. Will you have the goodness to inform the Committee if they may reckon on your support, and to what extent in aid of the existing deficit."

The "whip" had the desired effect, and several answered "gamely" to it: so much so that $£$ I 23 was soon contributed. Mrs. Morrogh gave $f_{10}$, and Messrs. Morrogh, Thomas Leonard, the late William Maxwell, W. Jameson, and J. R. O'Reilly gave $\ell_{1} 0$ each ; Messrs. P. Aungier, C. Aungier, J. Fitzgerald, Joseph Hone, S. Mangan, R. Murdock, W. Murland, jun., Joseph Murphy, W. T. Stuart, and Thomas Turbett 
gave $\ell 5$ each, and so did Captain Leslie Martin; and Mr. Carleton gave $£ 3$. Charles Brindley during his many years' service as huntsman has given the utmost satisfaction. He is an adept at the multifarious duties attached to the post which he fills; and he is a most popular servant. He was born in England, in 1817 , and from his earliest years evinced a love for out-door sports and pastimes, and a great regard for those animals which contribute so much to our enjoymentthe horse and hound-and an attachment to the national pastime of hunting. When a young boy he went into the service of the late Thomas Carr, of Hednesford, near Stafford, who was then a very successful trainer. He remained there for seven years, and during that time rode three races, without success, at Bromyard and Bridgeworth. He was then engaged by the late Lord Howth, who was just at that time in his "palmiest day." He kept a pack of harriers, and Brindley acted as second horseman and whip, his Lordship hunting the hounds himself. In 1840 , when Lord Howth purchased Mr. Broadley's Staghounds, and brought them over from Leamington to Howth, "Charley" continued on as whipper-in. In 1842 , Lady Howth died; and, as I have already stated, the Staghounds were then disposed of. Captain Tait just at that time retired from the army, and went to live in Ayrshire, took the mastership of hounds there, and appointed Brindley whipper-in. However, after one year's absence, "Charley" returned to Ireland. The then master of the "Wards," Mr. Peter Alley, was in want of a huntsman at the time, and engaged him, and he has held the appointment ever since. Though he has "over Ashbourne ditches grown gray," 
he is as fond of the sport now as ever; his heart is still as keen as the youngest of his followers in the field. I hope he will carry the horn for years to come. His son Jem has been whip to him for several seasons, and knows and does his business well, and his urbane conduct in the field claims the highest approbation. An enumeration of the good men and true who have ridden with the "Wards" were a labour of love; but it would require a "sizeable" book to itself. Every cavalry regiment in the service has given its quota, and the names, Godman, Slacke, Ainsley, Annesley, Hoey, Candy, Bates, Bell, Campbell, Forrester, Forster, Greene, Warburton, Johnstone, Barclay, Townley, Towers, Tait, Handly, Musters, Lawrence, Hutchinson, Paulett, Prettyman, Kingscote, Beresford, Dixon, Fraser, Little, Severne, Trotter, Kearsley, Clanmorris, $\mathrm{M}^{\prime} \mathrm{C}$ Calmont, Lee Barber, and Hartigan are themselves such a record of first-flight soldiers as is not to be found in the annals of any other pack. I regret that the exigencies of space forbids my dilating on their prowess, but I must rather hasten to notice the men of to.day, whose effigy is so cunningly set out in the Ward Hunt picture, which has been on view in Grafton-street.

On the right is the late Captain John Ferguson Montgomery, of Ballydrain, Antrim, of which county he was a D.L. and magistrate. No better supporter of sport than he was, has these many years emerged from the North. While yet in mourning for his gallant brother, "killed in action" in the Crimea, he made one of a very hard-riding trio, who occupied in common the comfortable hunting quarters, Roseboro', between Johnstown and Naas. Mr. M'Gildowney and Mr. 
M'Neil were his companions, and ranks of the Antrim Rifles, then quite the crack corps of the Irish territorial army, as often rang with the recital of the doings of the hard riding "Antrim three," as it did with the feats of drill by "Jack M'Kenzie's chickens" on the drill-grounds. Poor Captain Montgomery's death is too recent to make it necessary to recall the circumstances; but it is not too much to say that his death "in harness" was not one which the good sportsman himself would have thought inappropriate, and was not uncharacteristic of a man who brought to bear on his pleasure the deliberation of canny Ulster, and a certain recklessness more frequently attributed to the natives west of the Shannon.

Mr. Preston I have dealt with elsewhere. Messrs. Duffy, Greenhill, Aungier, Mangan, and Leonard, are very well known men to the "Ward" followers, and deserve to be remembered in any memoir of hard riding Irishmen; and the same may be said of Mr. "Tom" Potterton, who adds the speciality, which called more than once for Viceregal notice, of being "quite a duck" in brooks or waterholes, especially to save any of the good deer which are "quarry" to the "Wards." The two Messrs. D'Arcy make good portraits. The elder of the two-uncle of the other, I think the most forward Irish polo player-is an ardent sportsman, though not very brilliant horseman. $\mathrm{He}$ has been Knight of the Shire for Wexford, and whether in his place in parliament, in the hunting-field, or presiding over the great industry which gives bread to so many of his fellow-citizens, ever displays a broad liberality which has gained him troops of friends. Charlie Brindley, "the tough old campaigner," has been 
noticed. Jem is a chip of the old block; and though not such a workman to get and keep with hounds as his sire was-when was there another ! - is a grand horseman. His figure intercepts the view of the no doubt reliable mount of $\mathrm{Mr}$. J. T. Power, formerly Mr. D'Arcy's colleague in the representation of Wexford. He is scarcely as well known as a hunting man as he is as holder of the "ribbons," in which he rivals his brother. in-law, Mr. J. R. O'Reilly, who occupies a prominent place in the opposite "flank" of Mr. Osborne's very clever picture. Those who have joined in the pleasures of the Ward Union Hunt cannot, these many years past, have been unobservant of one of these phenomenal horsemen who with one arm can do so much more than most men with two. Of these, Mr. T. Butler, of Priestown, is a very notable example; and warm friends of this right good fellow in camp and barrack, over the Queen's broad empire, will recognise with pleasure his happy portrait, which the artist has introducod between those of the Brindley's - father and son.

Thè name of Watson will be familiar to my readers, while all will allow the honourable mention which their merits as sportsmen entitle them to. The Mr. $\mathrm{H}$. Watson of this picture is a near relative of Messrs. Robert and George Watson, the respective masters of the so far divided packs, the Carlow and Island, and Melbourne hounds. He, unlike them, has not yet carried the horn; but our coaching annals, polo-grounds, and hunting-fields abound in records of his accomplishments and prowess. Between him and her husband, the chief of the Ward Executive, Mr. Osborne presents us with an excellent portrait of Mrs. Leonard 
Morrogh. Those who have seen her performances in the hunting field will be glad to acknowledge how suitably this lady is mated to the gentleman whose conduct in and out of the field has done so much to establish and sustain the prestige of the Ward hounds. Mr. Morrogh is an admirable horseman, and hailing as he does, from the very difficult but sport loving neighbourhood of Fermoy, where he was "entered," it is not hard to account for those qualities which distinguish him in getting through the queerest places in any and all sorts of runs on the accomplished horses which he knows so well how to purchase. The first celebrity in that way he had was a very big Sir Herculeus grey horse which, perhaps, enjoyed as deserved a reputation as any other hunter in any other country.

Mr. Cranfield will, no doubt, obtain many purchasers for the admirable autotype of the picture under notice, if only on account of the very striking likeness of Lord Spencer. His popularity here was unabated by any political considerations, and the crowd of good sportsmen, who still preserve warm recollections of his hospitalities and his horsemanship, will, no doubt, contribute to swell the numbers of Cranfield's clientele. And Lord Spencer's friends in the Shires, and the flourishing Althorp tenantry, who love him so well, will be pleased to preserve a record of the time when some twelve of the latter, the guests of their noble landlord for a week, tried conclusions with the best men of old Ireland over the "grass" of Dublin, Meath, and Kildare. The writer would hope that Lord Spencer, whether as Viceroy or unattached, may find his way to Ireland again; and within the 
covers of this book he has written no lines, except the dedication, which afforded him more pleasure than those in which he fearlessly expresses for his countrymen their admiration of Lord Spencer's character, and the cead mille-failthe with which they would hail his return.

Major-General Smyth occupies, perhaps, the most prominent position in the foreground, and no admirer of horses can pass over the admirable manner in which his good hunter is treated-indeed this applies to Lord Spencer's, the Brindley's, and Dr. Duckett's horses-but that is saying little, not known to all who have seen the artist's equestrian portraits. Technically they are admirable pictures; and the difficulties of holding two gray horses in opposition on a foreground, filled up by the "pied beauties," would be patent to any artist who knows how much trouble must be taken to avoid destroying all harmony by what painters call "spottiness." The very special merit of this picture is, however, the "character" with which the hounds, the horses, the men, the very landscape is in view. Doctor "Billy" Duckett sits there by his many friends, and we see his every turn as if dipping in his often used snuff-box. Then Mr. Thompson, Mr. Meldon's portly figure, Mr. D'Arcy, and Mr. R. J. Montgomery's keeneyed, weather-worn face. How admirable they convey the men!

The late Mr. Maxwell, of Cruiserath, is also a "feature" of the picture, and I cannot forbear some kindly mention of the fine old sportsman, who, a few months age, sat for this portrait in the full vigour of ripe but unstricken manhood. He for many 
years kept a pack of harriers for the gratuitous amusement of his grateful neighbours. Close behind him is a very characteristic portrait of Mr. Thomas Harper, and but that he has become in his long residence amongst us, like our early Norman conquerors, more Irish than the Irish themselves, I should be disposed to treat him with the courtesy we should ever extend to visitors. The recollections of his many splendid victories between the flags in this tight little island, have obliterated those earlier and very frequent triumphs when Mr. Harper was wont, in succession to his fath er, to sweep the Border racecourses of their prizes in true "Reiver" fashion. Mr. Harper's father was of the school which gave to Scotland such sportsmen as Ramsay of Barnton, Lord Eglington, Sir Joseph Boswell, Lord Glasgow, and Mr. Meiklam: they raced for stakes without considering the "Ledger." Mr. T. Harper, the youngest of a sporting family, commenced in his twelfth year a career of, till quite lately, unvaried success by scoring the Roxboroshire Border Plate at Hawick, where, for many years, as at other Border meetings, all the best things fell to his share.

Such well-known faces as Mr. J. Hone, Mr. Turbett, and Mr. Jameson are easily recognised. No better supporters of Stag-hunting are to be found; and there is no one who goes straighter than Mr. Hone, though Mr. Coppinger, and Mr. W. A. Maher, his neighbours, on the canvass, are rivals in the field not unworthy of him, or any "flyer" of the hunt, here or elsewhere. Mr. Drury, Mr. William Fitzgerald, and Mr. James Kelly, all good men 
and true, complete the group which assembles close by the Castle of Kilreisk, which is seen in the background.

The Ward Hounds hunt on Monday, Wednesday, and Saturday. There are at present 32 couple of working hounds in the kennel, and they are remarkably good, good-looking, and well bred. 


\section{CHAPTER IV.}

THE MEATH HOUNDS.

As I look back upon the annals of fox-hunting in Meath, I find that for considerably more than one hundred years the spirit and love of the noble science have flourished there. But in bygone days, instead of one pack supported by all, and hunting the whole country as at present, several gentlemen kept private packs, and as at that time foxes were scarce and coverts few they did not limit themselves to the "wily" animal but also hunted hares. Indeed such was the case with every pack in Ireland at that remote period. The first date I can find relative to hunting in Meath is that of 1740 . Mr. Lowther of Huddlesworth, kept a pack, and at the same time, or very soon afterwards, packs were kept by Mr. Gerrard of Gibstown, Mr. Pollock of Mountainstown, Mr. Hopkins of Mitchelstown, and Mr. Waller of Allenstown. Much good fellowship appears to have existed between all, as one hunted one day, another the following, and occasionally all the packs were joined together for one grand day's sport. The condition of the pastures of Meath was scarcely as good then as at present, for in some places where hunting is just now easy it was then rather disagreeable, and it very often happened that huntsmen had to dismount and run on foot, the boggy 
nature of the ground making riding impossible. In I 745, Mr. Nicholson of Balrath, kept a pack, which was the first kept in the country exclusively devoted to hunting foxes, and some idea of the difficulties they had to contend with may be had when we find it the practice of the time to go to some well-known haunt of the fox before break of day, where, glad to shelter themselves under some friendly bank, these hardy sportsmen used to await the return of the fox to his earth, and at the first dawn of the wintry morning lay the pack on his trail. We can well imagine how welcome the gallop he led them must have been. In 1816 , this state of things came to an end, and most of those packs which were scattered about the country were joined into one club, which consisted of twelve members, viz., Messrs. Christopher A. Nicholson, Walier, John Gerrard, A. H. C. Pollock, C. A. Tisdall, Wm. Cruise, Robert Longfield, John Payne Garnett, Andrew Cruise, George Everard, Henry Pendleton, and Hamlet Garnett, four of whom subscribed $£ 50$ each, and the other eight $£ 20$ per annum. They were called the Clongill Hounds, and the kennels were at the old castle of that name, the ruins of which may still be seen. On the death of Knipe, their huntsman (which was caused by his breaking his neck in a fall from his horse near Slane), John Grennan, with his sons, Jack and Denny, held office. A hard-riding man was he, and always inclined for a forward cast.

The management of the pack for fourteen years was undertaken by Mr. William Waller of Allenstown. A separate pack had still been kept by Mr. Hopkins of Mitchelstown, but in 1832 , this was 
amalgamated with the "Clongills," who removed their quarters to Mitchelstown, near Athboy, Mr. Hopkins being master, and were then for the first time called the Meath Hounds. There were at this time very few gorse coverts in the county, and foxes certainly were not numerous; the best were at Bengarstown, Mitchelstown, and Balrath. Swainstown and Kilcarty were then, as now, famous fox haunts; the country was not at that time as extensive as at present, but they hunted over what is now decidedly the "cream" of "Royal Meath's" luxuriant pastures. During Mr. Hopkins's mastership they met regularly once a month at Corbalton Hall, the handsome residence of the late Mr. Corballis, M.P., as good a sportsman as ever lived, and one who represented the county in parliament for many years, won the esteem and regard of his constituents-indeed of all true Irishmenand who exerted himself very much for the advancement of the hunting interest. Dan Grennan was huntsman at this time. The next master was Sir C. Dillon, with Henry Wilnow, an Englishman, as huntsman. He was followed by Mr. T. B. Thompson, who became master in 1836 , and gave them up in 1839 to Mr. James N. Waller of Allenstown, who kept them until 1841, when he gave them up to a committee consisting of Messrs. John Tisdall, John Pollock, and Thomas Rothwell.

In 1845, Mr. Trench Nugent took them. This gentleman gave great satisfaction during his reign, and he was subsequently master of the North Warwickshire Hounds for some years. He gave them up in 1852 to the late Mr. S. A. Reynell. Then a new era opened for foxhunters in the county Meath. Many 
of those who were connected with the many packs which were in the county before he took the title of M.M.F.H. were undoubtedly sportsmen true and tried, but no man ever did more to promote the interest of foxhunters in Ireland than Mr. Sam Reynell. He improved the country immensely; he established coverts in all directions, and the gorse may now be seen flourishing in desirable situations throughout the extensive hunting-grounds of the "Meaths." Before he commenced his reign no hounds hunted beyond Trim, whereas now their district is, without exception, I think, the largest in Ireland. Most of my readers have heard of Bengarstown gorse. When Mr. Reynell took the pack this covert was three acres in extent; he made it double the size. It was situated on his own property, and notwithstanding the frequent visitations of Reynard's enemies to it he is seldom an absentee now.

"They may come-they may draw it as oft as they will, The bouquet of foxdom will cling to it still."

When Mr. Reynell was master he was obliged to hunt only five days a fortnight, but he was one of those mighty Nimrods who would, if possible, hunt six days a week, and run a drag to church on Sundays, and he used frequently hunt four and five days a week. He received $\ell^{1,000}$ per annum, and a few years before he resigned the subscription was increased to $f^{1,200-a}$ sum not at all sufficient to cover the outlay. He deserves much praise, too, for having founded that useful body of distinguished sportsmen, the Foxhunting committee of Ireland. Will and Tom Mathews, and George Cox, now with Lord Eglington, were huntsmen under him; but in the latter years of 
his reign he himself hunted the hounds, and with very great success.

On his giving them up, in 1872 , they were taken by the present master, Mr. Wm. Newcome Waller, with $\mathrm{M}$ B Bride as huntsman. The latter was succeeded, in 1876 , by Frank Goodall. They hunt regularly five days a week, and for several seasons they have had uninterrupted good sport, the country being full of foxes, and farmers and gentlemen equally keen about their preservation. Before concluding, I shall say a few words about those good sportsmen, past and present, who have distinguished themselves in the field. In the days of the old "Clongills," Frank Hopkins, John O'Connor, John Thompson of Rathnally, T. Somerville (brother of the late Lord Athlumney, and one who, I am glad to say, is even still able to show a straight line across country), and Mr. Coddington of Oldbridge, were all known as very good men. The Church was also well represented, and the Archdeacon of Meath (De Lacy), and the Rev. Frank Saunderson, from Cavan, were very hard to beat. In more modern times, Mr. Robert Wade of Clonbraney, Mr. Richard Barnwall of Blumsberry, were really good men, also the late Mr. W. S. Garnett of Rosneen.

On reference to the archives of the Meath Hounds, I find that the ancestors of the present master have been long connected with the pack. No man living is more devoted to the " noble science" than he. Though the task of officiating as master is to him a "labour of love," nevertheless, there are but few men would undertake hunting five days a week over such an extensive territory; but he 
never fails to put in an appearance, and during the summer time pays great attention to the coverts-a duty, I fear, overlooked by many masters of hounds. The kennels are situated about one mile from Allenstown House, and they are excellent. Kennel lameness is almost unknown. The pack is $A_{I}$; strains from the best blood procurable are to be found amongst them, and drafts are procured annually from Curraghmore. In England, as well as in this country, M`Bride has acquired a good reputation, and I have frequently heard very good judges speak highly indeed of his merits. His successor, Goodall, is also a very accomplished huntsman-as by pedigree he ought to be. The whips are John Bishop, J. Colton, and H. Rees. The hounds hunt every day in the week except Wednesday, and the pack consists of 70 couple. 


\section{CHAPTER V. \\ THE LOUTH HOUNDS.*}

FEI occupations are so congenial to my taste as that of inspecting a pack of hounds on the "flags," and every true and devoted lover of the "noble science" will coincide with me in thinking that a sportsman can desire no greater pleasure. I fear I could not find so many to agree with me on this point (if they would make an honest confession) as in the days of our forefathers. I am not going to write about the degeneracy of the age, or to affirm that hunting and other manly sports and pastimes are not now as formerly, or that the breed of horses and hounds are deteriorating. Our canine pets-foxhounds, staghounds, greyhounds, and others-have all been improved in every particular by judicious breeding and management within the last quarter of a century. Some fifty years ago there were no foxhounds in the country except the slow old Irish breed, whereas now we may see in almost every kennel in the land hounds perfect in symmetry and faultless in shape, descended from importations from the kennels of such hunting celebrities as the Duke of Beauford, Lords Henry Bentinck, Portsmouth,

* This chapter, and a part of my biography of Henry, Marquis of Waterford, and of the chapters on the Meath, Westmeath, and Queen's County Hounds, were published in the Irish Sportsman some months ago. They were written by me for that paper under the nom de plume of "Harkaway." 
Coventry, Poltimore, Fitzwilliam, Spencer, Yarborough, Fitzhardinge, Scarborough, Sir Watkin Wynn, \&c.-in fact, from all the best establishments in Europe. Our ancestors had a greater love for hunting and hounds than we have. Many go out now to have a gallop across the country, many to "show off" in faultless costume, others to escort some fair friend, and carry on a flirtation, in the absence of pater and mater familias, but few to enjoy the working of the hounds; and several members of our hunt clubs - perhaps the majority of them-do not know the name or pedigree of a single hound in their pack, and unless the "beauties" race "heads up and sterns down," declare the sport bad, and feel called upon to grumble, find fault with the master, the huntsman, or his aides, although, perhaps, they themselves would have been macadamising on the highways and byways, whether the pace was funereal or express. Fortunately, in the state progressive in which the world at large rejoices, it is not to be expected that our sylvan pleasures should remain where they were, or that the horse and hound should escape the onward march of improvement; nevertheless, a quiet, patient, judicious huntsman is seldom seen in the present hark-holloa, helter-skelter generation, when few seem to bear in mind the important fact that hounds should hunt by scent and view and not help and horn.

It is not my intention to write an essay on hounds or hunting, but I think that the few remarks I have written cannot be considered out of place when dealing with the subject which now occupies my mind.

It was with feelings of pleasure that I started on 
Monday morning by the nine a.m. train from Amiensstreet en route to Lisrenny. Any person who has travelled on this line could not have failed to notice the beautiful country through which the railway passes. I had an ample opportunity of admiring, as I most certainly did, the beauties of nature. On one side, for miles, a grand marine view may be had, while on the other is a charming country, dotted with stately mansions and pretty villas. Clontarf recalled to mind sanguinary struggles, the Danes, Corney Delaney, " ugh the hathens and Turks," Jack Hinton, and Charles Lever. Then, as Howth's high hill catches my eye, my thoughts turn in another channel, and I think of the days when the black and white jacket of the late lamented lord of the soil was carried first past the post by Kingstown, Mince-pie, Nelaton, Royal Arms, Sutton, Malahide, and other good racers. Balbriggan suggests, of course, schoolgirls and hosiery. After a pleasant journey of an hour and a half's duration, I am once more on terra firma at Dunleer. A couple of miles further on, as I journeyed to Ardee, I espied the old stand-house at Mullacurry. It is to be regretted that this once popular steeplechase meeting has been allowed to fall to the ground. Many a grand race I and hundreds have witnessed over this good course, where the sport was always first-rate, and the arrangements, in every detail, almost perfect. I hope some sportsmen in the country will endeavour to re-establish an annual reunion there. When Mr. Philip Callan, M.P., resided in that neighbourhood, he was immortalised by a local poet for

\footnotetext{
"The races young Callan got up in Ardee."
} 
He was, indeed, the prime mover and principal promoter of them, and he used to watch with particular interest the artistic performances of Messrs. Moore, Whyte, Exshaw, Captain Smith, the brothers Ryan, Gavin, and other "giants in the pigskin." After a drive of about eight miles I arrived at Lisrenny House, the residence of the master of the Louth Hounds, Mr. W. De Salis Filgate. The mansion is a very comfortable one, nicely situated in the centre of a rich country, and surrounded by fine old timber. Having received a cordial welcome from Mr. Filgate, he accompanied me to the kennels, which are neat, clean, and, no doubt, healthy, though plain and small. The pack comprise 33 couple of hounds, averaging, I should think, about 24 inches. There are not many of them very remarkable for beauty, but few amongst them are really faulty. They have a deal of work to get through, and there is so much plough and woodland in the hunting district that they must be very steady and good workers-as they undoubtedly are. They are more remarkable for sterling worth and great substance than for perfection of symmetry and appearance. They were brought before me in litters, and the junior members were first called upon to answer to their names. The entry last year was much smaller than is generally the case, as Mr. Filgate was particularly unfortunate with his bitches.

The first lot comprised a quartette by the Belvoir Drayman, from Careless. Caterer is one of the largest-indeed I think the biggest-dog of his age I ever saw. He will, no doubt, improve in appearance, but is not a very attractive-looking youngster just now, yet he has a good character. Of the others I 
preferred Courtesy, a very good-looking hound. Violet, by Viceroy, from Rosey, is a very neat bitch, but not built on a big scale. Her sire has proved a very great acquisition at the stud, and was got by Sir Watkin Wynn's Cardinal, out of Vengeance. Gainer and Gambler are by Guider, from Affable; the former very good-looking, the latter a capital worker, Harry Hardy assured me. A trio by Viceroy, out of Darling, are promising, and one of them (Daffodil) is a very neat and symmetrical hound. Volatile-a black and white by Viceroy, from Bashful-I admired greatly, but Vagabond, one of the same litter, I did not think much of. Gallant, by the Cambridgeshire Gransden, is not faultless by any means. Countess and Crazy, by the same sire, out of Cheerful, are a pair of "beauties;" the most fastidious critic could scarcely find a fault with Crazy. A quartette by the Meath Beauford, from Affable, all pleased me, and the veriest tyro would be struck with the good looks of Ambush. Vagrant, out of Cheerful, by Viceroy, is a very good-looking dog, with well-shaped feet, capital shoulders and loins. The cross between the Warwickshire Nestor and Affable by the Meath Argus, out of Magic, was most successful, as the five of the latter are all good, strong, useful-looking hounds. Nimble has not the, good looks of the others, but Nestor is a rare, good-looking dog in every respect, and, I believe, one of the best of the pack. Nelly, the only other of this litter, was taken to Meath, but unfortunately she went blind. Nestor was thought a great deal of ; but he was old when he came over here, and the night he arrived at Lisrenny he strayed away, but was found in the county Kildare, 
and died not very long afterwards. He was, indeed, a great loss. Clasher is a very good-looking dog by Vaulter, out of Cowslip. Like his sire, he is an excellent hound, and is generally the first to pick up the scent at a check. Wild Boy is a white and fawn by Warwickshire Wild Boy, from Chauntress, one of the same litter. Welcome is, in my opinion, the pick of the kennel, few better-looking bitches ever proclaimed a find. Strange to say, she has to be kept with the dog hounds, as she would fight with her own sex. Touchstone and Traffic are by Vaulter, from Tell-tale, a famous bitch; some of the blood has been in the kennel for very many years. Dewdrop and Despot, by Cambridgeshire Gransden. out of Darling, are both good and good-looking. I regret to say that one of the same litter (Duster) was killed recently in a field by a gentleman riding over him. Mr. Filgate says that he never owned a better dog. Abigail by Warwickshire Wild Boy, out of Ardent, is very good looking, and a first-rate bitch. Her brother, Charon, is a very big hound, yet a well-put-together one. Rufus is a very valuable dog, with good shapes, low and lengthy. The next on my note-book, Marmion, by Majesty, out of Charity, is first-rate at marking to ground; a sister, named Madcap, is thought a great deal about; the third of the litter, Marplot, I did not like at all. A fawn, named Lapwing, by Lord Fitzhardinge's Gainsborough, out of Liberty, is very shy, but, I am told, very good. Comus and Careless are by Mr. North's Random, from Cheerful; the lastmentioned is highly spoken of by Mr. Filgate. Bondsman, by Cambridgeshire Scamper, from Brevity, is one of the best-bred dogs in the pack, and the only 
one of the litter. When he retired, I saw a trio by Vaulter, out of Ardent-Ajax, Albion, and Assheton. The first-mentioned has been in the infirmary, and does not look well; Ajax is very good-looking, and better even than he looks. The five-year-olds were then called out. Lounger, by Linkboy, out of Vanquish, appeared to be very timid. Cardinal, by Viceroy, is one that would please any critic, and, I believe, he is very like his grandsire and namesake-a dog that belonged to Sir Watkin Wynn. Bellman, by Brusher, out of Chauntress, is a "commoner;" nor did his half-brother, out of Tell-tale, impress me favourably. Guider, by Warwickshire Brusher, out of Gaiety, is a true-shaped hound, indeed perfect in build. The six-year-old bitch, Darling, is by Belvoir Drayman, from Liberty; she would be a great acquisition to any kennel. Victory, by the Meath Argus, out of Violet, pleased me very much, and is a wonder on plough. Violet was by the Pytchley General, out of Vestris. Poor old Affable has done a great deal in the hunting-field, and reared several of the best hounds in the kennel; she is a grand old "lady," and is by the Meath Argus, out of Magic, by Mussulman, out of Festive. Affable's hunting days are now over; and Advocate, a valuable hound by Asteroid out of Violet, was killed, in 1876 , by a kick from a horse.

There are fourteen hunters in the stables - a good stud of useful, wear-and-tear horses.

The following brief history of the Louth Hunt may be read with interest: In the early part of this century, Louth was hunted by several packs of harriers, and the first attempt at establishing a county pack was about 1817 , when the late Mr. Sheills of Newtown 
Damer, and Colonel Filgate of Lisrenny, joined their packs for the purpose. The pack was kept some years by Mr. Sheills, and the first record we have of the Louth Foxhounds' meets being advertised is in I 820. When Mr. Sheills gave up the hounds, they were taken by the late Mr. Fortescue of Stephenstown, who went to great expense in joining the country and getting together a first-rate pack of hounds. During Mr. Sheills' time a man named William (or Billy) Kelly was huntsman, and he was succeeded, when Mr. Fortescue took them, by Patrick Cleary. Mr. Fortescue gave up the hounds in 1837 or 18.38 , and was succeeded for about three seasons by the present Mr. Mervyn Pratt of Cabra Castle, who hunted the hounds himself, his first whip being Thomas Mathews, who afterwards became huntsman, and held the horn till 1857. After Mr. Pratt resigned, they were for a season or two in the hands of a committee, with the late Mr. Straten of Dundalk at its head, and about 1842 , were taken by Mr. Arthur Upton, till 1846 , when they again fell into the charge of a committee; but in 1848 , they were taken by Mr. William Ruxton of Ardee House, who carried them on till 1854 . The present Lord Bellew then had them for one season, and in 1855 they were taken by Mr. Robert Haig of Dundalk, who kept them for five years, handing them over, in 1860 , to the present master. During Mr. Haig's mastership, in 1857, Thomas Nathews was supernnuated, and he was succeeded by a namesake, another Thomas Mathews, a man very celebrated in his profession both in England and in Ireland. When Mr. Haig retired from the mastership, Mathews went to the Meath Hounds for one season, and then 
returned to England, where he hunted the Warwickshire Hounds for several seasons.

Mr. Filgate began with Thomas Powell (who had been huntsman to the Cottesmore and Lord Henry Bentinck's hounds) as huntsman for five years, but in 1865 he assumed the horn himself, and has ever since hunted the pack, with Harry Hardy as first whip and kennel huntsman.

Louth itself is a rough country, with a great deal of plough, and the best portions of it are the parts of Meath and Dublin, which these hounds hunt. The coverts, as a rule, are mostly demesnes, with some thirty-five gorse coverts scattered at intervals.

The family of Filgate is one of the "oldest" and most popular in Louth; they have for many years been connected with the County hounds, and have done a great deal to promote the interests of the foxhunters in their native land. Being one of a family so remarkable for their love of hunting, it is not to be wondered at that Mr. William De Salis Filgate, while a very young man, gave sufficient indication in what direction his taste lay by taking the mastership. The length of time that he has filled the post speaks trumpet-tongued in his favour. No man ever filled the role more worthily. In the field he preserves the gentlemanly demeanour that characterises every action of his life, and renders hunting with him so agreeable. He is passionately fond of his hounds, and is a very good huntsman-indeed I may say there are

" Few more skilled the noisy pack to guide,

To urge the chase, to cheer them, or to chide."

The fact that during the seventeen years which he 
has had the hounds, he has had only five changes of his hunt-servants is, to say the least of it, a good sign. In many countries the frequent changing of masters, huntsmen, and whips, militates greatly against the sport. Huntsmen and whips must know a country thoroughly well to be perfect in their business. A master should pay strict attention to the breeding of his hounds, and unless he is thoroughly acquainted with the different peculiarities of all members of the pack he can never breed first-class hounds. This knowledge is not easily acquired. Not only must a man be well informed in stud lore, but he must have seen and studied the results of the different crosses in blood before he can be versed in the science of breeding. Harry Hardy is a most. popular servant, and a very good one in every respect. He came to Lisrenny as whip in I860, and has been there ever since, save that he left, and lived in England for a season or two, and then returned. He first served as whip to Mr. Briscoe. The sport this season has been first-class; Mr. Filgate assured me that he never had better sport in the month of November. I am sorry to say the "fields" are generally very small. Foxes are numerous throughout his country. I may remark that an earth near the kennel is occupied by one or two pet foxes, and add of Squire Filgate that at all seasons

\section{"A fox is his delight-}

But most a wild one for the morning."

I have to thank him for a great deal of kindness and hospitality, and I hope my readers will derive as much pleasure from reading this notice of his hunting establishment as my visit afforded me; if they do they will be thoroughly pleased. 


\section{CHAPTER VI.}

EN ROUTE TO GALIVAY.

"YoIck! Yoick! Yoi! Get away, hark to Tell-tale!" shouts Will Freeman, in Punchestown covert. "This ought to be a good scenting-day - cloudy, and a southerly wind, too," remarks my nearest neighbour. "They have found," says Mr. Fleetwood Rynd, who, well mounted as usual, is standing in his stirrups look. ing over the covert-bank; and in a moment afterwards we hear a whimper, the "music rose in snatches," and after a few minutes more have elapsed, every hound joins in a chorus; the spiny gorse is waving to and fro, as we all get as close as we can to the huntinggate, and are on the qui-vive. Captain R. Mansfield is stationed in the gate, and says quietly: "He has stole away," as he sees Lord Clonmel, mounted on his beautiful chocolate chestnut, at the lower end, on the race-course side, with his hat in the air. "Gone a-a-way, gone a-a-way!" shouts Will Freeman, and he cheers the hounds to their fox.

" Hold hard, hold hard!" cries Captain R. Mansfield, as he pulls across the pass-way (he goes well, but, like a good sportsman, he likes to give hounds a chance). The "field" is steady for a few moments, then we hear the horn and crush through the narrow gate, several in their haste gallop past Byrne's house, and on to the Grand-stand, thinking that reynard, as is 
generally the case, has "skiddadled" in the direction of Eadestown before they perceive that the hounds are racing towards Elverstown. Across a few fields they are overridden: it is always so when they go this line, as there are but few fences, and the scent lies well. "Shame on you, gentlemen; do hold hard, please, and give them a chance!" exclaims Mr. Edmund Mansfield, most courteous of masters, whose mild rebuke, never given except when necessary, has more good effect than the more emphatic language of another would have. We leave the Black Hill to our left, and soon meet a nasty thorn fence: we cannot see over, and can scarcely see through. Mr. H. E. Linde, mounted on his chaser, Christmas Gift, charges it, gets well over, and enjoys a lead for a time. Mr. Robert Kennedy can't be stopped on his little gray mare, and sometimes negociates the most intricate fences on her. On this occasion he gets up through the bushes in a place where few follow. However, after a brief delay all the firstflight men get over. "Who are those gentlemen who sit their horses so remarkably well ?" inquires my friend, Jack Gostraight, who is a stranger. "Colonel Forster and Captain Richard Moore of Killashee." "Did you ever see men with better seats in a saddle?" "I never did; the Colonel is evidently master of the horse, in more than one sense of the word; and the Lancer appears to be a perfect mènage horseman." Just then I see several in front of me stopped at a very big bank, and one gentleman in scarlet, riding a very good-looking black horse, goes straight at it, and does it in brilliant style, just as I get near enough to recognise him -it is $H$. $R$. H. the Duke of Connaught, 
on Black Knight, late Captivator. The pace is "killing ;" for Elverstown we are bound; the "weeds" are done now, and the "duffers" are furlongs behind. "Ware-wire," exclaims Major Lawless, who is first on to the road, near the "Longhouse," all right, and on we go up the opposite hill towards the next fence, when Baron de Robeck (who is as usual in the front rank) shouts: "This way, this way! you will be 'pounded" there; follow me." So we do. The Baron has not a particle of jealousy in his composition, and is always anxious to see others with the hounds as well as himself. The next we meet is a nasty fence; Mr. Alexander Graydon is the first up. "That is very big," he says, turning round in his saddle, having got over with a struggle. "The bigger the better," exclaims that good horseman, Mr. Joe Kilbee of Cannycourt, as he jumps it close in his wake. The next we meet is a regular "yawner," and nearly all make for a gate which is beside it. "Give place to the ladies, gentlemen," says a man beside me, as Miss Beauman, Miss Kilbee, and Miss O'Kelly, all come up together : they seldom look for gate or gap, and on this occasion all go at the ditch, and are landed safely into the next field. The "varmint" is headed near Elverstown, then makes back towards Punchestown for a short distance before he points his mask for Eadestown; they hunt on by Hoystead's hook to the road. The fox then makes towards Athgarrett; the field has become really select, and as they race up the hill, the only persons with the hounds are H.R. H. the Duke of Connaught, Lord Cloncurry on Polly, his brother, Major Lawless, on a favourite hunter, Mr. Percy La Touche on a gray, Mr. Fortescue Tynte on Sweet Pea, Mr. Wm. 
Blacker on Snowstorm, Mr. Wm. Kennedy on his chestnut, Baron de Robeck, Major Dent, Mr. E. Mansfield, Freeman, and the first whip.

My poor nag is completely "done," and I merely catch a glimpse of those in the distance-I wonder will I ever get him over this narrow bank? "Come up, go on! -bump-bump-bum! —Oh, by Jove! we're down-a "cropper!" I have him by the bridle, though-no, he's gone-fire in my eyes too-'twill be a case of concussion. "Get up, get up," says a voice beside me, and a hand is on my shoulder. "All right, all right -I'm not hurt_catch the d_—d brute, catch him." " Tickets, please-show your ticket, sir. Athenry, Athenry, Athenry!" shouts a sleepy porter. I push back my travelling-cap, rub my eyes. What the deuce is this? Oh! I thought I was riding a run, and here $I$ am at one o'clock in the morning at Athenry. The guard has been shaking me for the last five minutes, holding his lamp within a couple of inches of my face (this accounts for the fire in my eyes). "All right, guard; I've been dreaming." "So I thought, sir, for you pulled at the chain of my whistle till you smashed it." "No matter; get out my traps; and here's half-a-crown to wet your whistle."

"I have the dog-cart outside, sir, and will have you at master's in forty minutes." "All right, John; go on," In forty minutes afterwards I have an old friend (who has invited me down to spend a few days with him, and has promised to give me a mount with the Galway Hounds, yclept the "Blazers") by the hand, and soon afterwards am talking of the likelihood of a good run on the morrow, and enjoying his hospitality. 
"I hope you had a pleasant journey from Dublin," he says.

"Oh! yes. I fell asleep after passing Mullingar, and was soon dreaming that I was riding a grand run in Kildare. People will tell you dreams go by contraries; don't believe it, though. I dreamed we were going over the line a Punchestown fox generally takes, and those who I thought I saw riding in the first flight were the very men who generally do. I could scarcely bring myself to believe that it was only a fancy."

"Oh! you must have seen such a run recently, that accounts for it."

"Well, now, I remember I did see such a one the other day, and my dream was very like what actually occurred."

"We will have an early start for the meet, and the small hours have come already-so to bed."

After dinner next day we adjourned to my friend's "snuggery," and our conversation I may set down for the behoof of all who wish to know of the Galway Hounds. 


\section{CHAPTER VII.}

THE GALWAY HOUNDS.

"Now," says my host, " have a weed."

"Thank you. I must cross-examine you about the 'Blazers,' their history, \&c. \&c. You know all about my book. I paid a visit to a friend of mine in Kilkenny Christmas week, and since then spent a few days with an old acquaintance in Waterford, and they gave me a great deal of information about their hounds; and I am sure you know a good deal about the Galway pack. So I made up my mind the moment I received your invitation to accept it, although very busy, as I am sure you will tell me all you know."

"Certainly, with pleasure, and will not state anything except what I am certain is correct. In the first place, you must know that the present Master of the Galway Hounds, Mr. Burton R. P. Persse, can boast of a distinguished line of ancestors, all of whom were, as he is, decidedly 'men for Galway,' and remarkable for their love of fox-hunting, their popularity, many estimable qualities, and sportsman-like conduct at all times. They were celebrated for their knowledge of hunting and good horsemanship. The grandfather of Burton Persse was so distinguished in this respect that he rejoiced in the sobriquet of 'the Irish Meynell.'"

"Yes, so I heard; and Mr. Burton Persse told me 
some time ago that he had at one time records of the hunt which dated back to the early part of the last century; he unfortunately lent them to a friend of his who lost them, and the oldest now in his possession is one of $1803 . "$

"Yes, his grandfather had hounds for many years before that; he used to turn them out in splendid style, and dress his hunt-servants in 'orange plush,' but he himself always wore the scarlet."

"Did he reside at Moyode?"

"Yes, in Persse Lodge, which stood where Moyode Castle is now, and the kennels were, I think, near where they are at present. Of course they were far inferior to the present kennels."

"Were there other hounds kept in the county at that time?"

"There were a few small packs, I believe, but the late Colonel Giles Eyre, of Eyrecourt Castle, for several years kept a large pack and hunted the lower end of Galway, also part of King's Co. and Tipperary, or Ormond. Of course you often heard of him; and you remember Lever's song :-

" 'The King of Oude

Is mighty proud, And so were onst the Caysars;

But ould Giles Eyre

Would make them stare,

Av he had them with the Blazers.

To the devil I'd fling ould Runjut Singh,

He's only a prince in a small way,

And knows nothing at all of a six-foot wall,

Oh! he'd never do for Galway.'

The Colonel was very wealthy, and spared no expense in improving the breed of his pack, and in mounting 
his servants, and all that, and spent his money like the Galway-men of his day. He expended a large sum on the hounds, too, but bred more for stoutness than speed; he carried this too far by crossing with the bloodhound and mastiff. Their courage and temper became so high that they would hardly brook correction; and the old huntsman, Nick Carolan, having indulged too freely in his 'beloved poteen,' went into the kennel one night without his whip and they ate him.

"In 1803 , the late Robert Parsons Persse formed a pack, and it was principally from the kennel of the present master's grandfather, ' the Irish Meynell,' that he founded it, as he reduced his establishment then and gave all his large hounds to him (he was his nephew); but 'the Irish Meynell' kept until within a few years of his death the small pack and the best blood in his kennel, which the present master's father kept up until he handed them over to him. So that for considerably over one hundred years the best and purest foxhound blood has been kept in these kennels by the three generations."

"How long did R. P. Persse keep them, and did he continue the orange plush uniform ?"

"He kept them till 1829. He resided at CastleBoy; and they were known as the 'Castle-Boy Hunt.' A club, composed of the aristocracy of Galway, was formed; and the uniform was scarlet, white collar, and 'Castle-Boy Hunt' on the buttons."

"It was during Robert Parsons Persse's mastership that the cognoman 'Blazers' was invented, was it not?"

"It was; two reasons are assigned for the alias 
which it has borne so long. One story is, that at a hunt dinner, it was proposed by Mr. Persse, and seconded by Robert French of Rahasane, that they should be called the 'Blazers,' out of compliment to Mr. Robert D'Arcy of Woodville, and James Burke of St. Cleran's, both of whom had ruby locks, and were consequently called the 'Blazers.' Mr. D'Arcy was at that time treasurer of the hunt. Some say that it originated in this way: While Robert Parsons Persse was master the hounds used to go once a year to Birr, where they were met by the members of the Ormond Hunt. After the day's hunting was over the men of both hunts dined together. Many queer stories are told of the extraordinary 'doings' at these festive reunions. To cement good fellowship they assembled; the loving cup passed quickly round, for the men of the period after worshipping at the shrine of Diana by day were wont to honour Bacchus at night. They were veritable 'umbrella nights;' and during one of those midnight orgies they set fire to the establishment of host Dooley, and it was burnt to the ground; hence, according to many, the derivation of the title. But I believe the other story to be the correct one. Mr. Robert Parsons Persse died in 1829 , and then the hounds returned to the kennels, where they have been ever since."

"Why, I thought Mr. Christopher St. George succeeded Robert Parsons Persse."

"Mr. St. George kept a private pack for a short time after Robert Parsons Persse's death, but the ancestors of the one now in existence never left the Persse family; and it was not until I 840 that the first subscription pack was established in Galway, 
under the title of the 'County Galway Hunt.' Mr. St. George lived in Tyrone House, and hunted the hounds himself; he spared no expense, and was well supported by Willie Hall and two whips."

"What became of the hounds when he gave them up?"

"He handed them over to his relatives, Anthony Nugent, now the Earl of Westmeath, and Mr. Hyacinth Daly of Raford."

"Where were they kept then ?"

"At Raford, and were managed by Mr. Hyacinth Daly, jun., who was a fine sportsman, and had a grand stud of hunters, as well as several steeplechase horses; he had them only a short time, when he, poor fellow, died very young. However his father retained them for a few years afterwards-until his demise, I believe."

"Well, who succeeded to the mastership?"

"A Committee had them for a short time."

"Who were on the Committee?"

"Mr. St. George, Lord Westmeath, and Mr. Robert Bodkin of Annagh. They determined to make them a county pack, and Mr. R. Bodkin exerted himself to the utmost. The gentlemen of the county promised him their support, and subscribed liberally - this was in 1840-and they appointed Mr. John Dennis master. They handed over a good pack to him. I need scarcely tell you, that John Dennis was one of the best sportsmen that ever breathed, perhaps the best rider that ever sat in a saddle, and there were few better men to ride a steeplechase. To pilot a rough horse, there certainly was no better in the world; he won many steeplechases, and 
for years used to ride in the principal races in this country; he generally had a few chasers in his stable, and always a rare stud of hunters. A better display of horsemanship never was witnessed than his on Dan O'Connell, when he rode him for the Liverpool Grand National-I forget in what year-the horse then belonged to 'Sporting Mick Yourrell,' as he was generally called; he bolted when going well not far from home. Another of the many wonderful proofs afforded by Mr. John Dennis of his prowess in the pig-skin was his marvellous feat, accomplished thirty years ago, when riding Fra Diavolo in a four-mile steeplechase, over the Macroom Course, Roscommon walls, many of them over five feet high. The horse's sight had been failing for some time, and during the race he lost it completely, yet he won."

"Oh! nonsense."

"It is a fact, and I can get many men who will bear me out in what I say, and one of them is a gentleman residing at the Curragh: but to continue my story; he had his opponents in difficulties a long way from home; he was seen to blunder over the last three walls, and he actually rolled over the last one, yet Mr. Dennis kept in the saddle. All who knew the horse were amazed, as he never was known to fall over a wall; he won, and when he returned to the enclosure it was found that the horse was STONE BLIND.

"At Lismacrory racecourse, near Birr, when a comparatively old man, he accomplished one of his memorable feats. Mr. 'Charlie' Lockwood once said of him, 'Jack manages a horse by Legerdemain.' I suppose the description was not a pun on the deriva- 
tion of the word, but Mr. Lockwood's ignorance of French did not take from the point of his description. If ever light-hands did wonders, Mr. Dennis's did, and so trained did his horses become that they worked as he willed. The feat I refer to was a proof of this. He had an old horse, a gray, called Monarch, which he was riding as a hack on the racecourse! I think it was the year of the great struggle between Brunette and Sam Slick-Eheu, what horses! The meeting was over, and some one complained of the height of a wall being raised for a match between two gentlemen hailing trans-shannonwards. 'Pshaw' said Dennis, 'I'd ride Monarch over it without a bridle.' A bet for some small sum resulted, and $\mathrm{Mr}$. Dennis rode Monarch, at and over five feet of a wellbuilt wall, his aids being his seat, his own and his good horse's training, pluck, and confidence, and a pair of cabbage stumps, with which an admirer from the West armed him to guide 'the auld horse, and shame the blusthering devils that didn't know the baste." "

"I have heard that story before; but he accomplished a still greater feat, as he rode a horse of his, I believe it was Monarch, over six six-feet walls with nothing to guide him but a halter and his whip."

"Yes, some say six, but there is no doubt about his having ridden him thus over four. Many years ago he rode a horse, I don't remember his name, at a meeting held this side of the Shannon, when the country was in a disturbed state owing to an election or something of the sort. Mr. Dennis was a great favourite, but he displeased some of the Galwegians at this time, and they made an attack on him while 
he was riding the race. They pelted him with stones, many of them hit him; and when he was coming at the last fence, a wall over five feet high, some ruffians, in order to stop him, pulled an ass and car across it, so that he could not get over unless he jumped the vehicle or donkey and the wall together. The plucky sportsman was not to be baffled; he sent his horse at it, and he flew the cart and wall in grand style: he must have cleared nearly thirty feet in the jump."

"He showed first-rate sport while he was master, you say; and used to have large fields too."

"Capital sport; a great many used to attend the meets, and hard riding fellows they were. The favourite covert was Castle Lambert, on the property of Walter Lambert, who was a thorough sportsman, and a capital rider to hounds. There was always a fox in his coverts; there were double stone walls, five-and-half feet high, bounding each park, and Lambert had holes made in them just large enough to let the fox through, in order to ensure his taking the stiff line. He built the walls purposely to 'try the mettle of the boys,' as he used to say; and to see them charging them was indeed a sight calculated to bring the 'crimson to the forehead and the lustre to the eye.'

"Mr. Dennis died rather suddenly, at Spadacinni's Hotel, Dublin. He was a bachelor, and some years before his death inherited from his uncle a large property; it was called the Birmingham Estate. I could tell you many stories of the wonderful feats of Hycie Dixon, Lord Clanricarde, and George Henry Moore (peace to their ashes, their like we seldom 
see). Dixon was a fine rider, and so was George Moore."

"The latter was as good a man to ride a race as a hunt, I am told.'

"He was, and he won several races; indeed, he was a sort of Admirable Crichton. In the early days of steeplechasing, when Mr. George Osbaldeston, Lord Waterford, Jem Mason, and Dick Christian were wont to ride their matches five miles, but taking them on line, and never to keep the road for more than one hundred yards, Mr. Moore shared with the late Mr. Val Maher of Ballinkeale, and Lord Waterford, the honour of upholding Irish horsemanship at Melton. Nimrod sung their praises, and he took part in the celebrated run-the article descriptive of which brought unwonted fame to the 'Quarterly.' A ripe scholar-indeed quite curiously erudite-an accomplished linguist, a connoisseur, an athlete, and a sportsman all round. Can we wonder that he was popular, especially when he added to all his other extraordinary accomplishments a melodious and commanding oratory, which made his hearers, on the platform and in the seriate, hang lovingly on his ringing, heart-striking periods?"

"He was lucky on the turf, was he not?"

"He was; he won many races in Ireland, and was a confederate of the late Marquis of Waterford-Lord Henry I mean, for some time-and his horses won valuable stakes in England. He won the Northamptonshire Stakes with Wolfdog, and after that his intimate friends used to call him 'the Dog.' He won no money over the race though, and was so disgusted at not having backed the right one, that he retired 
from the turf for some years; however, he came on again, and won the Stewards' Plate and Chesterfield Plate, at Goodwood, with Erin-go-Bragh. Some years before his death he gave up racing. He died in 1870 .

“In 1850, Mr. John Mahon of Ballydonnellan succeeded Mr. Dennis, and kept the hounds for three years, during which time the sport was good."

"What became of the pack at Moyode? You said they returned there after Robert Parsons Persse died."

"They did, and the present master's father hunted what we called the 'home circuit' with them, and continued to do so till ' 48 , when his son became old enough to undertake the management of them. He kept them on; and when Mr. Mahon gave up, in '53, Mr. Persse undertook to hunt the whole country; he has done so ever since in a manner which has reflected the highest credit on himself, and given the utmost satisfaction to every one."

"You have not yet told me about the huntservants."

"Any person who has heard of the 'Blazers,' has heard of the celebrated Sam Smith. When Mr. Robert Parsons Persse had the hounds he was whipper-in, and afterwards huntsman for a short time ; then when they came back to Moyode, he returned with then, and hunted them until the present master took them (he has always hunted the hounds himself), and Sam was first whip and kennel huntsman. For some seasons before his death, he was the recipient of a pension from $\mathrm{Mr}$. Persse. He died in 1875. He was ninety years of age, and spent his 
whole life (with the exception of three years, during which time he was huntsman to the Staghounds kept by the late Lord Howth) in the service of the Persse family, and lived also as huntsman for one or two seasons with Mr. H. Daly of Raford. Richard Conroy whipped under Sam Smith, but you tell me you have heard all about him."

"Oh, yes! I alluded to him in the history of the Ormond Hunt."

"Michael Boyle served as first whip, and kennel huntsman for about ten seasons, he then went to Mr. Longworth, and was his huntsman for some time. When Boyle left, eleven years ago; Joseph Turpin came from the Cottesmore Hounds, where he lived with Sir John Trollope (afterwards Lord Kesteven) as whip. He left last summer, and George Browne is promoted, and John Croft, from the Badsworth, acts as second whip. George Browne came to these hounds, four years ago, from Shropshire, where he learned his business, and learned it well too."

"Well, what about the stables and kennels?"

"The stabling is excellent; perfect, I might say, in every particular; and the kennels are large, airy, and kept as well as possible. The hounds are as good a pack as there is in Ireland. And no wonder. The ancestors of the hounds now in the Moyode kennel were celebrities in Castle-Boy more than seventy years ago; and long before that, as I have already told you, the Persse's kept fox-hounds. And I have also told you that the present master, his grandsire, and father were judges of hounds, lovers of hunting, and spared neither time nor expense in endeavouring to 
make the pack perfect. There are fifty couple of hounds now in the kennels; fourteen were entered last year, and they turned out very well. Mr. Burton Persse keeps a very good stud of hunters: there is no better judge of a horse. He has had a few good steeplechasers-Topthorne, Arab Maid, Zuleika, Ab. dalla, Sultana, The Huntsman, Stella, and many others previously. He is a very good man to ride, and has often sported silk."

"What is the extent of the hunting district, and where are the best parts of it?"

"The country from Loughrea to Pallas, and from Loughrea to Fairfield is magnificent and almost entirely rich grassland-indeed nearly all the country is grass, and rides light. The kennels are within three miles of Athenry, where good accommodation can be had for man and horse at the Railway Hotel, or Kinsella's. The hunting days are Tuesdays, Thursdays, and Saturdays. The sum guaranteed to Mr. Persse is $£ 1000$ per annum, and I need scarcely tell you that it does not nearly cover the expenses."

"Will you mention the names of those who were first-flight men in days long gone by ?"

"I will. In no part of England or Ireland will you find better men to ride than in Connaught. I cannot remember all who were deserving of being included in the list of the 'leaders of the chase,' but I will mention a few who were wonderful riders. Lord Clanricarde and John Dennis, were 'clinkers' in the hunting-field and between the flags. Burton Persse, father of the present M. F. H., was considered the best rider to hounds in his time, and had most perfect hands. Parsons Persse, his brother, was an 
accomplished rider and won a great many steeplechases, and owned several famous horses, among others, Economist, sire of the great Harkaway. John Lambert of Aggard, Walter Lambert of Castlelam. bert, and Robert Ffrench of Monivea Castle, were firstrate riders. Robert Bodkin of Annagh was a good man, too, on a horse he had called Kenilworth; he was 'a bad'un to beat.' John Mahon of Weston, Nicholas Blake of Frenchfort, Martin Blake of Merlin Park, Parson D'Arcy, and Pierce Joyce of Mervue, were all good men in their day. I need scarcely tell you, as of course you often heard of many of his astounding feats in the saddle, that the late Lord Clanricarde was as accomplished and bold a horseman as rode over a stone wall in Connaught or anywhere else. Did you ever read the memoir of his Lordship which appeared in Baily's Magazine eleven years ago ?"

"I did not?"

"Well, I have it here; it is about the best biography, in my opinion, that ever appeared in that excellent periodical; and, I need not add, that it is well worth reading."

"It must be very interesting, indeed. Please read it for me. Baily says :-

“" The Marquis of Clanricarde, whose portrait we would have presented to our readers before this, but for his public and private engagements preventing him honouring our artist with a sitting, is the most fitting representative of the Sportsman of Ireland in the present age; and it is only due to himself and ourselves that his deeds on the Steeplechase Course and in the Hunting Field should have some more enduring memorial than that conveyed by a local newspaper paragraph. 
"'The family of De Burgh, from whence the subject of our memoir is sprung, ranks among the most distinguished in Ireland, and deduces an uninterrupted line of powerful nobles from the Conquest. The Marquis of Clanricarde, the present head of it, was born on the 20 th of December, 1802 , and succeeded his father as fourth Earl on the 27 th of July, 1808 , and in 1825 he was advanced by Letters Patent to the Irish Marquisate, and created a Baron of the United Kingdom. Eton and Oxford can claim him among their alumni ; but at this distance of time no anecdotes of his school or college career are current, but it may be taken for granted he was a young man of promise, or that great statesman, Mr. Canning, whose daughter he married, would not have selected him as his private secretary. Commencing life at a period when Irish wit, Irish society as it was of old, and Lever's heroes were still flourishing, and the Galway Blazers were yet extant within his native county, Lord Clanricarde entered heart and soul into all the hilarity which surrounded the sporting circles of his immediate neighbourhood. At that time daring horsemanship and sporting accomplishments were considered as the high road to distinction, and, with the social advantages which he possessed, tutors were not wanting for so apt a pupil; and after perfecting his education in the art of riding over high walls-and no better school can be found to attain to first-class horsemanship-his Lordship made his début on the Curragh in 1822 , winning the first Corinthians ever ran in Ireland on Penguin, by Waxy Pope, beating six others. In the following year he repeated the victory with the same animal, beating the celebrated Roller. $\mathrm{He}$ also won a good race on the flat at Loughrea, in his native county, on a wretched-looking animal called Sarsaparilla, belonging to the parish priest, which so delighted the peasantry, that as they cheered his Lordship coming back to scale, they exclaimed: 'Sure if he was on an ass of Father Peter's, wouldn't he have a right to win!' But to the turf Lord Clanricarde was never really partial, while to steeplechasing, on the other hand, he devoted himself with all the enthusiasm of Irish youth; and he may be said to have won his spurs shortly after leaving Oxford, in 1822, over the Roxborough course in Galway, on Hawk, by Scherdone. The course was four miles over a stiff country, including four five-feet walls, and the last one measured five feet nine inches at the spot where the Hawk took it. He won the same stake the next year on Mr. Persse's Rollo; but 
nine inches had been taken off the last-mentioned wall. In 1830 , at Luton Hoo, in what was called the first St. Albans' Steeplechase, got up by the well-known Tommy Coleman, and for which sixteen started, he ran second to Lord Ranelagh's gray gelding, Wonder, ridden by Captain M'Douall of the Life Guards, with a little Irish horse called Nailer, who had just only landed from Ireland in hunting condition. The course was an unflagged one, and that Lord Clanricarde's fame had reached Hertfordshire was clear when Captain M'Douall in asking how he was to ride the Wonder, was told simply to pay no attention to anybody, but to wait upon Lord Clanricarde. True to his orders, Captain $\mathrm{M} \cdot$ Douall never deserted his pilot, and at one period in the race exclaimed, 'Halloa! you're going wrong!' But the turn proved correct, as the first and second came in some minutes before the others appeared, Nailer having at the end to succumb to the superior turn of speed of Wonder. His two next appearances in the Metropolitan district were more successful, as he won two Grand Steeplechases on Mr. Elmore's famous Moonraker, beating good fields of first-class horses. The last of these races finished over a very strong line at the Windmill, near Old Oak Farm, on the Edgeware-road; and on this occasion, it was always reported that Moonraker, who was a hard puller and a very big jumper, cleared a lane. At the period to which we refer, Lord Clanricarde had been a frequent attendant with Mr. Grantley Berkeley's stag-hounds, which were then kept at Cranford, and having distinguished himself in several runs over the Harrow country, Mr. Berkeley, after he became the master of the Oakley Hounds, got up a steeplechase at Bedford, and asked Lord Clanricarde to ride for him. Parliament was sitting, and there were no railways in those days, but his Lordship was not to be denied, for he rode a couple of hacks down the road to Bedford, rode his friend's horse in the steeplechase, rode back again to town, and attended in his place in the House of Lords in the evening.

" 'Having sketched, somewhat too briefly we fear, Lord Clanricarde's sporting exploits, we will now discuss his merits as a horseman, and we are not saying too much in stating he may be classed among the most remarkable men across country of the day. His forte lies in possessing the art of imparting confidence, or enforcing obedience to every horse he gets on. He can ride a brute with the vigour and determination of a Dick Christian, he.can 
humour and encourage a timid or half-broken horse by patience and good temper, or he can guide a finished hunter like a gentleman. While gifted with the skill of a perfect ménage rider, he exemplifies, as he goes over a country, that horses, when let alone at their fences, seldom fall. Impressed with the necessity of having a full command over his horse, he generally rides with severe bridles, and is most particular about the fitting of his curb, which he may be seen altering several tinies during a day's hunting; such tackle requires good hands, nor are they wanting. His seat is graceful, his style of riding simple, not a symptom of the more modern steeplechasing element being visible. Never flurried or in a hurry, whether the fence is a mere water-cut or a binder leaning towards him, or stiff timber with bad taking off: it seems a matter of perfect indifference as he holds on the even tenor of his way. Certain malpractices to secure a start, or to take any unfair advantage by overriding hounds, he never availed himself of, nor was he over particular in selecting the weak spot in a fence, for with him the shortest way was the best way. It is a pleasant sensation to get away on a good horse abreast of the leading hound, but many a good man succumbs when he misses his start, having, perhaps, fifty men before him and fifty men around him; and few have pluck and resolution to overcome difficulties-such as the certainty of being ridden on if your horse makes a mistake, or the collisions threatened by bad and reckless riders. But a bad start never deterred Lord Clanricarde; for he could tread his way with perfect ease through a crowd, and bide his time with patience until a check or lucky turn let him up to the front; and when the pace had begun to tell, when horses' legs were dropping into the opposite ditches, when the timber rattled under their feet, or the sob of distress gave warning that induce most prudent men to look out for the nearest by-road or line of gates, he could assist a beaten horse over a country with consummate judgment and skill.

" 'To him nought came amiss,

One horse or that, one country or this, He through falls and bad starts undauntedly still Rides to the motto: Be with them I will.

" Running such risks, he could scarce come off scathless, and although frequently knocked about, his activity, his presence of mind, and his spare figure often saved him from serious consequences. But no man ever received punishment more unflinch. 
ingly. Early in 1854 , on a Saturday, in Leicestershire, a weedy Birdcatcher horse gave him an awkward fall at timber; and he felt his collar-bone go crack. But, getting up again, he had not gone three fields when a piece of water appeared, and the horse never rising at it, he got under him, and was at once extricated half-drowned and much bruised, and, as it turned out, with his collar-bone broken in another place. On the following Tuesday, however, he was at his post in the House of Lords, and spoke for forty-five minutes without a check, on the impending Russian war. We should state, however, that the deep interest which the Marquis has ever taken in politics made hunting and the stud secondary considerations; and the rapidity and seeming carelessness with which preparations were made for a visit to Melton or The Shires were quite appalling, and afforded a remarkable contrast to the practice of the present, when Mason, Newcombe, Darby, and Sheward require many weeks' notice before collecting a Leicestershire stud for fastidious gentlemen. On one day the Marquis would appear on a plain, hunting-like horse, on the next on a weedy thoroughbred, on the third on an ancient far advanced in his teens, or very groggy on his legs, and perhaps a couple of awkward horses to ride completed the stud. From Melton they were then perhaps transported to do duty over the stone walls in Galway, or among the intricate fences in Kilkenny or Kildare.

“. It seemed a perfect matter of indifference to him what he rode, as the following anecdote will illustrate. Passing through Dublin, he called on a well-known friend of every sportsman. 'Hunt,' he said, 'can you let me have a horse to ride with the Kildare Hounds ?' 'I am very sorry, my Lord, I have nothing to offer you just at present,' was the reply, 'What! not a horse in your stable?' 'Nothing, my Lord, but a one-eyed horse I bought from a miller to carry a whip. I hear he has been hunted, but I know nothing about him, and he is in moderate trim.' 'Never mind ; send him on. I will be at the meet.'

" 'The well-known covert of Laragh was the first the hounds drew; and the first fence was the brook (now bridged over), simply a ditch about fourteen feet in width, with a high bank on the opposite side. The field diverged to easy parts of the fence; but the Marquis on the chestnut (afterwards called Nelson), came straight down at it, got well over, and went first in a gallop of seventeen minutes. 
" As might be anticipated in so long a career, Lord Clanricarde has from time to time been the owner of good horses: among the best in former days were Leatherhead, a gray horse that had the honour of being the last that Mr. Val Maher ever went in his old form on in Leicestershire. This horse hunted up to the age of twenty-seven, and at that age jumped an undeniably big fence on Barrow Hill. Angelo, 'a perfect fencer,' carried the Marquis for ten years; then Gehazi, 'a leper' as white as snow ; and in later years Caustic, who in 1864 won the Irish Grand National within three weeks of his appearance at a Leicestershire covert-side. It would be hard to find a more awkward horse to ride hunting than Caustic, with his head all in the wrong place, a loose neck, a hard, unyielding mouth, and a desire to go as hard as he can at every fence. Mr. Long, who rode him in the National Race, to this day describes his 'sensations,' as the horse rattled in and out of the lane at Punchestown with him.

" "In politics the Marquis of Clanricarde has ever been a decided Liberal, and has supported with earnest eloquence measures that have been introduced into Parliament to forward the interests of Ireland. $\mathrm{He}$ has also filled the offices of Ambassador to St. Petersburg and Postmaster-General. We may also conclude by remarking that Lord Dunkellin-whose motion in the House of Commons on the Reform Bill led to the break-up of the Russell Administration-is the eldest son of the Marquis, and will succeed him in his titles and estates.'

"Poor Lord Dunkellin did not long survive the date of this notice. He predeceased his father by some years, and Ireland lost in him a nobleman who in all the relations of his life did credit to an illustrious old race. As soldier, statesman, scholar, and gentleman he had few equals, and his early death was no less than a national misfortune."

"Who are the best men of the present day?"

"Messrs. Burton Persse, Frank Joyce of Mervue, John Eyre, jun., Acheson French, Lord Dunsandle, Thos. Tully, Pierce Joyce, jun., Robert Blake of Brooklodge; the late Lord Clanmorris, who died suddenly 
last year, was a capital sportsman and devoted to hunting-he was a great loss to everyone, but especially to the hunt, as he was our best supporter; John Blakeney of Abbert, John Comyn (who is the able and energetic secretary of the hunt), and Mr. Henry Persse. And no one goes harder or further than Mr. Andy Dolphin; Major French and Mr. Christopher Usher go well too. I have told you all I know about the Galway 'Blazers,' and now I will sing you a song which was written a few years ago by as good a fellow as I ever knew. He has gone to 'the land of to-morrow.' Those who knew the author will recognise the style which pervaded all his happy compositions; and if it recalls the memory of so cheery a good fellow, it will evoke some pleasant recollections such as the many friends of poor Charlie Kerr were indebted to him for.

\section{“THE GALWAY 'BLAZERS.'}

"I read in the papers of runs that, be japers, Just sound to my ear in a small way;

If yez want for real sport, faith ye'd better resort 'To neglected but grand-goin' Galway.

"Your horse must have mettle, wid hounds in such fettle, And walls that are terrible tazers;

His condition the best, for he's sure to be prest, If yez mean to ride up wid the "Blazers."

"If you go there a stranger, bedad there's no danger, They'll trate ye to all o' the best, boys;

For lord, lout, an' squire good ridin' admireAll sportsmen they welkim with zest, boys.

"By the side of that gorse, on his stuffy blood horse, Sits the master, whose hounds none surpass;

And the man that would bate him might as well try to ate himHe'll soon make acquaintance wid grass. 
"And now for his hounds. To his fame it redounds

That he owns the best pack in the world;

O'er the fields in a cluster they run such a 'buster,'

Like leaves by a hurricane 'whorled.'

"Such loins and such shoulders skim walls built o" bouldhers, Tho' Rinard may make bould resistance;

They've dash, blood an' strength, limbs, nose, too, an' length, So they care not for pace nor for distance.

"No noise or disorder, the fields in good order, All coming for sport, not for ' gaggin' ;'

Yez must be pretty smart and try bould for a start, For here there is really no 'laggin'.'

"Now of fair girls"I sing, who, like birds on the wing, Lead the first flight throughout the whole gallop;

Yet sit graceful, an' go when they hear 'Tallyho''Och,' the divil a man they can't 'wallop.'

“'Thin 'Hurrah for the Blazers,' an' 'the ladies that plaze us,' May Burton hunt fifty years more, shure;

As thro' luck an' disaster, as huntsman an' master, He has hunted the country a score, shure."

"Very good; I suppose I must respond to your call, so I'll sing my favourite song:

\section{“THE IRISH HUNTER.}

"I've as good an Irish hunter as ever trod the lea, How neatly he picks up his foot, how well he bends his knee; And such a head and rein he's got! and such a depth of girth,

With hocks, and loins, and quarters, to bring him through the dirt.

Jolly boys, jolly boys!

Hurrah for the fox and the hounds,

Jolly boys!

" He looks a little plain at first, but jump upon his back,

And in a moment you'll find out he's no common plain bred hack.

He feels as strong as any horse, yet airy as a feather,

$\mathrm{Oh}$ ! that's the lad to carry you through plough, grass, or heather.

Jolly boys, \&c. 
"To see him by the covert side, a snaffle bridle on, While other horses prance and fret, how quietly he stands; But when the hounds their fox have found, and settled on him steady,

He champs his bit, and shakes his head, to let you know he's ready.

Jolly boys, \&c.

"Now, I'll tell you of a glorious run we had the other day, When my good old Irish hunter he came through all the way;

For he's no weed or flashy one, no mere hunter in a stall-

But what good sportsmen like to style through steel, and whalebone all.

$$
\text { Jolly boys, \&c. }
$$

"The place of meet was Punchestown, the hour eleven o'clock, When Mansfield with his beauties came up quietly at a trot; The field being placed, the hounds thrown in we're all on tippy toe, When Freeman from the southern end, cries out: Yoick, tally ho ! Jolly boys, \&c.

"Now let the hounds get well away! Hold hard! a field or twoAnd let the beauties hunt his line, and run him straight and true : Pick up your reins-hold down your hands-now don't be in a flurry;

For a true-trained Irish hunter he wont leap it in a hurry.

$$
\text { Jolly boys, \&c. }
$$

"The first we meet's a double bank, a grip both out and in, He tops the ditch, he kicks the bank, and off he goes again; Some narrow-backed ones, a wall or two, aye, stiff ones on my word, But my gallant Irish hunter, oh, he does them like a bird.

$$
\text { Jolly boys, \&c. }
$$

"The next we meet's a nasty one, a deep drop with a lane,

Where if he makes the slightest mistake we're to grief 'tis very plain ;

But my gallant Irish hunter to defeat he ne'er would yield-

He goes at it forty miles an hour and trigs from field to field.

$$
\text { Jolly boys, \&c. }
$$

"Now up a hill I take a pull to give him time to breathe, And as my friends go past me their jeering I don't heed;

For when they get unto the top, they're blowing fit to die,

I take old 'Paudeen' by the head, and say: Gentlemen, goodbye !

Jolly boys, \&c. 
"And now the pace is mending, and the "garrons" spurt is done, The field become select, and they drop off one by one;

And when Freeman cries 'who-whoop!' and sings the death halloo!

There are none to join the chorus but myself and one or two.

$$
\text { Jolly boys, \&c. }
$$

"Here is to this gallant Irish hunter, may he never lose a shoe; May all his knocks and ills wear off like morning dew.

May his rider always lie in front, and ride him straight and true, And remember that he's 'Irish,' and his nag is Irish too.

Jolly boys, \&c."

"May Burton Persse hunt the 'Blazers' for many years to come in 'grand-goin' Galway. A more devoted fox-hunter never lived, and there is no more popular sportsman in the kingdom." 


\section{CHAPTER VIII.}

\section{THE CARLOW AND ISLAND HUNT HOUNDS.}

Although the Carlow and Island Hunt does not rank in the same class as the "Blazers," Kildare, Meath, or Curraghmore Hounds, I will venture to assert that Mr. Robert Watson has, for many years, afforded the Carlovians an opportunity of enjoying as good sport as their neighbours.

As to the history of the pack there is little to be said, consequently this is one of the shortest chapters in my book. Few different presidents have ruled over them, for the honoured name of Watson has long been inseparably associated with the Carlow Hounds.

During the first quarter of the present century, the Kildare Hounds used to hunt a greater portion of the Carlow country, particularly in the vicinity of Burton Hall, and Oak Park. When Sir John Power held the reins of office in Kilkenny, he, periodically, hunted the western portion of the country, and occasionally Coolattin. About the year I808, the late Mr. John Watson, father of the present master, commenced to hunt foxes. Before then there were other packs in the county, but they were disposed of soon after Mr. Watson started his. A few years afterwards it was thought desirable to start a subscription pack, 
to hunt the entire county, and hounds were procured, and kept by Mr. John Whelan of Rath.

In 1826, the late Mr. Watson got the country again. He carried the horn himself for many years, and then Tom Smith (afterwards huntsman to the Brocklesby) hunted them for a season.

In I 845 , Mr. Robert Watson succeeded his father, and has been master ever since. $\mathrm{He}$ is, I need scarcely say, quite devoted to the glorious pastime. Comparisons are odious, but I think none will cavil with me for stating that he is the best gentleman huntsman in Ireland, and a most competent judge of hounds. No breeder can be more painstaking, and the result of his good judgment and exertions is, that he has now a grand pack of hounds. He is cheery in the field, but a stern commander; keeps his companions in the chase in good order, and insists that they will ride to see hounds kill and not to kill hounds: and, as many other masters do, sometimes gives unruly ones a little "Dawson pie." One day, having come to a check, with a bad scent, and the fox a long way ahead, he was making a careful cast forwards, when a rather junior member of the hunt, but relative of his own, came up to him, saying: "Robert, don't you think the fox has gone to your right more?" "Yes, if I was a damn fool," was the quick rejoinder. When I say that Mick Connors has been whipper-in to Mr. Watson for the last twentyfour years, and came to him with the Island Hounds, being for some years previously whipper-in to the late Mr. Bolton, I need pass no enconiums on him.

There are generally forty-eight couple of working hounds in the kennels, which are situated at Mr. 
Watson's residence, Ballydarton, Bagnalstown. They have all been bred there, principally crossed with the Belvoir, Brocklesby, and Fitzwilliam blood. The hunting district is one of the largest in the kingdom, and comprises all Carlow, a small portion of the Queen's County, and Kildare; and, since 1853, that part of Wexford known as the Island country, formerly hunted by the late Mr. Bolton. This division is a fine wild country, with light hills, and includes a large portion of the north of Wexford. The Ferns part of the Island territory, and the Kildare side of Carlow, is the "cream" of the country.

Nearly all the gentlemen of the county subscribe liberally to the hunt fund. Lord Fitzwilliam, Messrs. H. Bruen, M.P., Arthur Kavanagh, M.P., F. M'Clintock Bunbury, J. M'Clintock Bunbury, H. Eustace, William Duckett, Charles M. Doyne, Captain Denis. Pack Beresford, Sir Charles Burton, Bart., Sir Thomas Butler, Bart., and Mr. Edward Irvine, are amongst the most liberal ; but no hunt can boast of more general support, although, in proportion to the extent of the country, the number of resident gentlemen and hunting men is small. Very few sportsmen reside on the Wicklow or Wexford sides of the district, so that the meets in the locality are generally badly attended. The "fields" average there about twenty; and on the Carlow side forty.

I will now mention a few who were first-flight men during the late Mr. Watson's mastership. There were at that time, as now, many "clinkers" amongst the followers of the Carlow Hounds. I cannot name them all, but the following were generally leaders of the van-Mr. John Watson, as a horseman, earned 
well-merited distinction, and was as good a rider to hounds as any of his cotemporaries; of Captain Casey, I may say the same; Colonel Bruen, and his brother John, not only in the Emerald Isle, but in many an English shire, earned fame as horsemen. On more than one page of this volume the name of $\mathrm{Mr}$. Horace Rochford of Clogrennon, is mentioned. He is a famous sportsman; as a rider to hounds, a polo-player, and a cricketter, he was mulli secundus; and he still keenly enjoys all manly pastimes, and is far superior to many of his junior rivals at those fine sports. The Messrs. Bunbury (2), Steward Duckett, Bagenal, H. Bruen, Charles Doyne, and Harman Cooper, are first-rate men to hounds; and so is the popular master, who, I hope, will continue to show good sport for many years to come.

I cannot pass over the name of Watson without making mention of the brother of the master of the Carlow and Island Hounds, who, some fourteen or fifteen thousand miles away, in her Majesty's most flourishing colony, has acclimatised, and made racy of the soil, the noble sport of fox-hunting. Two-andtwenty years ago, Mr. George Watson first "laid on" the Melbourne foxhounds to a jackal (the late Colonel Roberts, agent for the purchase of Indian "remounts," had imported twenty of the wily Indian substitute for Reynard). Since then Mr. Watson has not only succeeded in establishing a pack of foxhounds, and mainly at his own expense, but has imbued the "sparse" dwellers of the "New Continent" with a hunting spirit, the exposition of which is represented by the hunt meets in the daily papers of no less than 
five packs of hounds in Victoria alone. In the colony the pursuit of jackals, or "corn-fed kangaroos," is no longer necessary. Foxes have been imported, and are too plenty. In the very interests of the pastoral inhabitants, it will be necessary to keep the " redmen" down. And when the sporting history of this already great country comes to be written, men must connect with the names Watson and Carlow the initiation and establishment of a noble sport. Mr. George Watson has not permitted, in his pursuit of the splendid fortune he has acquired, his early proclivities to be diverted; and the Australian Calendar has no name of a gentleman rider with so many " brackets" opposite as his. 


\section{CHAPTER IX.}

THE TIPPERARY HOUNDS.

"Gallant Tipperary!" Strange, is it not, that I should begin my brief notice of the Tipperary Hounds with this hackneyed phrase. I deem the title-first applied in the heat of battle by the great conqueror of Scinde, Sir Charles Napier, to the 22 nd regiment-so apt, that I cannot refrain from using it. The inhabitants of the county have been misrepresented, and some years ago many Englishmen and foreigners were foolish enough to believe that it would be safer to take a trip through the most uncivilised part of the American Continent than to the Rock of Cashel. Yet, the natives are quiet, peaceable people, and devotedly attached to all field-sports, or, as they say themselves, a "trifle of divarsion" of any sort. The boys of Tipperary are remarkable for their cheery humour in love, war, or a foxhunt. They are, indeed, "gallant and gay," and decidedly liberal in their hospitality and political opinions. People of all classes in the county are glad to see the hounds in their neighbourhood. Hunting has been at all times popular there with "gentle and simple." Landlord and tenant, the red coat and the broadcloth, have met at the cover-side in amicable warfare long before "equalising" 
theories had inoculated the brain with fixity of tenure as the panacea for all our country's ills. Their "fixity of tenure" was, in the saddle, the only "eviction" thought of the fox. Some seventy years ago, Mr. Tom Barton kept a pack of foxhounds at his residence, Grove, and hunted what is now the Tipperary Hunt district. Mr. Barton was a devoted disciple of Diana's, and enjoyed a deserved popularity. Although his hounds were not as "level as a die," or as " handsome as paint," he showed very good sport during a régime of about twenty years. His huntsman was Johnny Ryan, the grandfather of the veteran of that name, who rode the winners of many valuable steeplechases for Henry, Marquis of Waterford, and who for many years hunted the Waterford Hounds. Mr. T. Barton was succeeded in the mastership by his brother William, who kept them for a few seasons-they were called "The Grove Hounds." Mr. William Barton knew the value of good breeding, and spared neither expense nor trouble in his endeavours to improve the pack. An uncle of his, who resided in England, procured drafts from the best kennels in the shires for him. One draft of a dog and bitch was a remarkable onethe bitch, whose name was Mercury, had performed some extraordinary feat in running a drag at Ascot before she was imported to this country, and, of course, was highly valued by Mr. Barton; she was mated with the dog sent to Ireland with her, and produced twenty-one puppies, all of which turned out to be first-class hounds. Mr. Barton became so delicate that he was obliged to give up hunting, and he sold his pack to Captain Jacob of Mobarnane, who showed good sport for the few seasons he hunted the country, 
and got some very good drafts from Colonel Thornbury's kennel. In 184I, Henry, Marquis of Waterford, purchased the pack from Captain Jacob, and the hounds were removed to Rockwell, near New Inn. The Marquis improved the country very much, had gorse coverts sown in the most desirable places, and got hounds from Mr. Villebois, who then had, I think, the Craven Hounds, and Lord Lonsdale, whose sturdy border-blooded pack imbued the "Tijs" with the enduring qualities they retain to this hour. The Marquis was, indeed, devotedly attached to all field sports. Whether the scent was good or bad, no day was too long for him. Prubably, some of my readers have heard the story of Goodall's jumping over the moon, which he did as reflected in the Melton brook, when he hunted the Belvoir Hounds during Lord Forrester's mastership, and who, whenever a gentleman asked him what o'clock it was, invariably replied: "I never carry a watch, sir, as my lord always draws until dark." I daresay Lord Waterford might say that he too jumped over the goddess of the night; reflected in some brook in Tipperary, for he used sometimes ride to his hounds when Luna was shining brightly. One evening, in the month of March, his lordship's hounds found a fox in Bansha, and ran him to ground near Thomastown. The Marquis said he should be dug out, and bagged. Spades were trumps, and Reynard was put into a sack, and brought several miles towards the kennel. "Now," said his lordship, "we're near home; let him go. Give him good 'law,' and we will have a run; he will, probably, bring us towards home." Reynard did not, but he gave them an extraordinary 
run. There was a full moon, and a good scent; and the Marquis, on a horse called Surprise, and Ryan, the huntsman, on a one-eyed horse, rode in brilliant style throughout. The fox was run into while endeavouring to jump a high wall near Thomastown, at twenty minutes past eleven o'clock at night.

The music of the hounds, crossing the country at such an hour, caused no small amount of wonder. A peasant who heard the Marquis's thrilling who-whoop! and the chimes of the pack, as the gallant old varmint was held high for a throw, was so terrified that he almost died of the fright; and for many a day stories were told by the country-folk about this memorable chase; and more than one amongst them firmly believed that it was his Satanic Majesty and his hellhounds that they saw. Lord Waterford hunted the country for six seasons. He had kennels built at Lakefield, near Fethard, but they were maliciously burnt down; this annoyed him so much that he gave up the hounds. But he presented several couple of them, five horses, and a subscription of $\delta_{1}$ oo a year to a committee of Tipperary gentlemen to hunt the country.

As particulars of Lord Waterford's very eventful career as a sportsman are given in a portion of this work, I need pass no eulogy on him here, though I cannot in a book such as this but mention the thrill of sorrow felt throughout Ireland for the sad fate that befel that public benefactor on the memorable March afternoon upon which he was killed, when

"Mayboy stumbled o'er the rotten wall."

The committee had the hounds for a short time, 
and then Mr. Millet kept them at St. Johnstown. He resigned after one season. Mr. George Gough, of Birdhill, succeeded him; and he, too, soon resigned in favour of Mr. John Going; and, I may say, in the words of a countryman of his own, "a better sportsman could not have them." He enjoyed the popularity his many endearing qualities entitled him tofrank, cheery, good-natured, and generous-no wonder he was esteemed by a legion of friends; and great was the regret of the foxhunters of Tipperary when ill health obliged Mr. Going to resign, in 1873, after a reign of over twenty years. His successor and nephew, Mr. B. F. Going of Ballyphillip, Killenaule, had them until the close of the seasons, 1876-7, and gave the utmost satisfaction. He loves the sport; understands hunting, and the breeding of hounds, and their kennel management. Nimrod, in his advice to masters of hounds, says. "Remember the apostolic precept, "be courteous.' "' Mr. Going is particularly so, and a favourite not only with the gentlemen of his own rank and station, but also with the farmers and peasants; and on those classes hunting men are dependent to a great extent for their sport. Patrick Coady, who graduated at Curraghmore, was huntsman to Mr. John Going for thirteen seasons; subsequently, John Heffernan carried the horn for a season or two. In 1873, Jem Maiden was appointed, and he held the situation until the end of the season $1876-7$, and, Mr. Going assured me, discharged his duties admirably. Mr. Bellamy, an English gentleman, remarkable for his love of sport, succeeded to the mastership, in 1877 .

The Tipperary hunting district is a fine grasscountry. 
The coverts number about sixty, and foxes are very numerous. It is to be regretted that the master receives rather lukewarm support-were such not the case, he could hunt the country six days a week. However, there are a few who subscribe very liberally to the funds. Notably, Lord Clonmel, Lord Donoughmore, Lord Lismore, Messrs. George Gough, sen., William Riall, and William Going.

The "fields" are generally small, averaging from twenty to fifty. There are many first-rate riders among the followers of the pack. Place aux damesMiss C. Quinn and Miss L. Quinn are generally amongst the first rank. It is no exaggeration to say, that Messrs. George Gough, sen. and jun., W. A. Riall, B. Going, H. C. Cliborn, T. Perry, J. Langley, M. Russell, and T. Phillips, are certainly deserving of honourable mention in any record such as this.

The pack are a mixed lot, averaging in height twenty-three inches, and are bred from the Curraghmore, the Burton Puckridge, Mr. Lane Fox's, Sir Watkin Wynn's, and the Kilkenny kennels. The kennels are very conveniently situated near Fethard, where they have been these many years past. They are at present occupied by twenty-eight couple of working hounds. Tuesdays and Saturdays are the hunting days. 


\section{CHAPTER X.}

THE WESTMEATH HOUNDS.

Although the Westmeath Hounds are not quite so familiarly known as most of the packs which I have already written about, a task such as mine would be very far from complete were I to omit a lengthened and accurate history of the pack since it was first established, and I have taken some care to procure all particulars relative to the hounds.

They were originally formed from a pack that existed at Killynon, under the mastership of the late Mr. S. Reynell, ex-master of the "Meaths," and the country was hunted by him from about 1842 to 1847 or 1848 , when they, with many other packs in this country, ceased to exist. They were again revived in I 853 by Sir Richard Levinge, the country having been hunted about three days a month by the East Meath Hounds by arrangement for some seasons previous. Sir Richard Levinge formed his pack mainly from Sir Richard Sutton's and the Oakley, with some drafts from other kennels. Jack Rawson was his huntsman, and a subscription was opened to give Sir Richard $£ 400$ a year for hunting the county two days a week. Foxes were then scarce, and there were very few gorse coverts, yet good sport was shown by the Baronet for two seasons, and it is to him alone 
the people of the county are indebted for having the present pack of foxhounds. Mr. J. A. Rochford Boyd, in 1856 , purchased the pack from Sir Richard Levinge, and they were removed from Knockdrin to Middleton Park, where they remained for a couple of years, and Rawson was succeeded by Jack Mossom. Mr. Boyd was not unsuccessful in his endeavours to show sport. He was a good master; and, as he kept a splendid stud of hunters, he as well as his servants was invariably well mounted.

In 1858 , however, there was another change, and Mr. Fetherston-Haugh Briscoe became master, and the hounds were brought to the Grangemore kennels, situated at the Killucan end of the county. Mitchell, who had been first whip in Kildare, was appointed huntsman, assisted by Joseph Barton as whip. Brilliant sport was participated in by large fields; foxes became more numerous, and Mr. Briscoe hunted five days a fortnight, and afterwards three days a week; but two years saw the end of his reign. The hounds remained in the same kennels, when Lord Vaux of Harrowden, in the most sportsmanlike manner, came to the assistance of the hunting community and formed a committee, consisting of Mr. J. A. Rochford Boyd, Mr. Fetherston-Haugh Briscoe, and himself, to carry on the hunting of the country. His lordship had always supported the foxhunting interests, and he induced eight gentlemen to subscribe in order to purchase the pack from Mr. Briscoe, which they did for $£ 400$, that they should have them as a county pack. Under the management of the committee the sport for a season was pretty fair, and then, fortunately, Mr. G. Dease (now a gallant major), 
brother of the owner, of Turbetstown, took the pack, and removed it to Turbetstown, at the other extreme end of the county.

In I86I, Joseph Burton was promoted to the horn, assisted by Robert Thompson, from Lord Middleton's, and there was a fair season's sport, only marred by a casualty, which caused great regret-the breaking of the master's leg by a fall in the middle of the season. J. Burton was, at the end of the season, succeeded by Robert Smith, from the Badsworth, who promised well, but fell sick in 1863 , and died after a few days' illness. The master then carried the horn till the end of the season, when Wm. Fisher, from the Hampshire, was engaged: as huntsman, $R$. Thompson still acting as whipper-in. The sport was only moderate, owing to the want of foxes.

In 1864 , the hounds were removed to Clonlost, near Killucan, where Major Dease went to reside on shis marriage, renting the place from Colonel Nugent, the staff continuing as before. In the year following, Major Dease undertook to carry the horn himself, William Fisher remaining on as kennel huntsman and first whip, and $R$. Thompson as second.

In 1866 , the master, having given up Clonlost, removed to Culleen, about one mile and a-half from Mullingar, and there, on a plot of ground rented from Mr. Tuite, county kennels were built, where the hounds have remained ever since. In that year the pack was strengthened by a present of several very good hounds from Lord Portsmouth, and they hunted three days a week, under the joint management of Major Dease and his brother-in-law, Sir William Trockmorton, well known since then as the master of the Vale of White 
Horse, till, in 1875, he was succeeded by Lord Shannon.

In I 868, Major Dease resigned. His reign will be long remembered, as his judicious management in every respect bore its fruit; the sport was truly excellent, foxes became more numerous, gorse coverts were made, the fowl fund carefully looked after-in fact, he did all that lay in his power to promote the welfare of his brother sportsmen, and his great popularity, knowledge, real love of the pastime, and his indefatigable exertions enabled him to do an immense deal. On his resignation, a handsome testimonial-a piece of plate value nearly $£ 300$-was presented to him, and he well deserved this token of the esteem in which he was held. He received only $£ 800$ a year, a sum which did not nearly defray the expense. For the last two seasons of his management, Robert Thompson was kennel huntsman, and Will Brice second whip.

A worthy successor to him soon came to the front in Mr. Morton C. MacDonald. After three years' experience of Irish hunting in Meath he took the hounds and horn, and the energy he displayed, the pains he took to improve the pack, the liberality of his expenditure in encouraging the preservation of foxes, and getting up a sporting spirit in the county, were the means of insuring three good seasons' sport. In his time Mr. Longworth sold his hounds, and they were added to the Westmeath. He kept a pack for many years at his own expense, and his country which was added to the Westmeath district extended from Streamstown to Athlone, about ten miles wide on either side of the M. G. W. Railway, 
but the hunting territory now reaches from Delvin to Athlone. A handsome testimonial was also given to Mr. Morton MacDonald when he retired in favour of a committee, consisting of Mr. S. Winter, Mr. J. R. Malone, and Mr. J. Tuite. I should mention that R. Thompson continued as first whip during Mr. Morton MacDonald's mastership.

The committee, after a few months, found a master, the late Captain R. Coote of Bellamont Forest, Co. Cavan, who was well known in the Duke of Beaufort's country, and Tocock, who was huntsman for a short time to Mr. Morton MacDonald, continued to act as such.

In 1872, Captain the Hon. R. Greville Nugent succeeded Captain Coote. He had Tocock as kennel huntsman during his first season, and Tom Drayton the second; he carried the horn himself, but resigned after two seasons to the great regret of every sportsman in the county. The Hon. Greville $\mathrm{Nu}$ gent, alias "Mr. St. James," is one of the most esteemed and noted patrons of the turf in Ireland. $\mathrm{He}$ served for some years in the Coldstream Guards, and was one of the most popular officers in that "crack" corps. About ten years ago, he first "sported" silk, and soon acquired the reputation of being one of the most successful and artistic steeplechase riders in the kingdom. More than once he stood at head of the annual list of successful gentlemen riders in Ireland; and his performance in Punchestown in 1875 , when he rode the winners of four races, is one of the most memorable feats recorded in the Irish Racing Calendar. Few men have filled the rôle of $\mathrm{M}$. F. H. more worthily. $\mathrm{He}$ is a member of a family which has for many years past been 
liberal supporters of the Westmeath Hounds. His fame will survive some generations of sportsmen, and his cheery humour and many good traits of character have earned for him a widespread popularity which I hope he will live long to enjoy.

A successor could not be found, and again the pack came to be managed by a committee, consisting of a trio of good and popular sportsmen, Captain J. R. Malone, Mr Ambrose More O'Ferrall, and Mr. Richard Reynell, who had been secretary to the hunt from the time Mr. Fetherston-Haugh Briscoe took office; Mr. Joly was then appointed secretary. Rose, from the Stafford Hounds, brought over as huntsman, and Will Mathews, who came in 1872 , continued as whip. Owing to the frequent changes of masters, things had got out of order, and the committee had a good deal to do to set them right, but fortunately success attended their efforts, and a fair season's sport was the result. Two of the committee resigned (Captain J. R. Malone and Mr. Ambrose More O'Ferrall) after one season, and Sir Walter Nugent and Lord Kilmaine joined Mr. Richard Reynell in the management. The improvement commenced the previous year continued, and a most successful season ensued; nineteen brace of foxes were killed, and hunting prospects brightened considerably during the year.

In 1876 , fortunately for Westmeath hunting folk, a popular young gentleman, Mr. Montague Chapman, eldest son of Sir Benjamin Chapman of Killeed Castle, one of the largest landed proprietors in the county, got the title of M. W. F. H., and Mathews, a very 
good man in the field and kennel, is huntsmanl, with J. Mason and Frank Toop as whips.

There are forty-three couple of good, useful working hounds in the kennel at present. The country is fairly stocked with foxes, to be found chiefly in the natural woods and demesnes, there not being many artificial coverts; but they are all the better for that, and take some killing. Parts of the country are hilly and not too easy to get over; but west of Mullingar is a fine grass country, with coverts few and far between, and there a fox must run for his life, for he cannot easily find a haven of refuge. Mr. R W. Reynell of Killynon, and Mr. Henry Murray of Mount Murray, may be looked upon as the fathers of the hunt; both were good riders in their day, and very hard indeed to beat, the latter especially being a very fine horseman, and in former days Major Dease was a veritable "clinker." In the first flight is now always to be seen Captain J. R. Malone, no ordinary welter-weight; Mr. O'Reilly is always very hard to beat, and Lord Kilmaine is generally the leader of the "light brigade." Mr. C. Coffy of Newcastle, also rides well, and is an ardent lover of hunting. It would be strange if his tastes did not incline in a manner which pre-eminently entitles him to mention in my memoranda of the chase, as, if there is any truth in the old saw, "breeding will tell," he is a natural sportsman. He keeps a very good pack of harriers, as did his father before him for very many years. Few names have been so long associated with the Irish turf as that of Mr. Richard Coffy, who bred and raced many famous racers and chasers - The De- 
formed, Twilight, Yaller Gal, Newcastle, Fertullagh, Gardiner, and Juryman, to wit. The subscription amounts to $f \mathrm{I}, \mathrm{I}$ IOO a year; they hunt three days a week, and if there were a few more gorse coverts the country is quite large enough for an additional day each week; the average number of the field is about thirty; and with more game the country would take a high place. 


\section{CHAPTER XI. \\ THE CASHELMORE HOUNDS.}

MORE than a hundred years have elapsed since the tuneful notes of the Cashelmore Hounds were first heard in the far-west of the county of Cork.

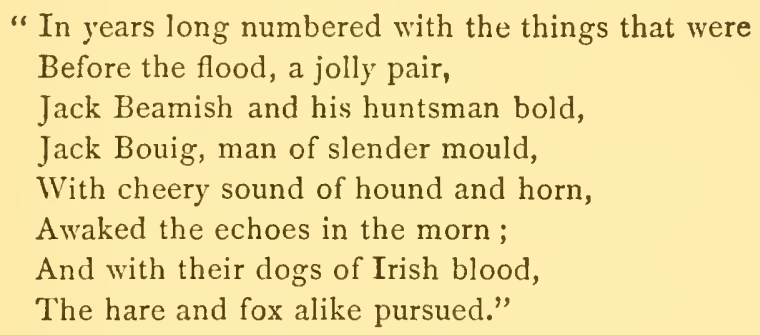

This pack was established in the last century, but at what precise time it is now impossible to say. It is a well-known fact, stated by Nimrod and other sporting writers, that the pursuit of the deer was the first hunting The hare then came to be hunted, probably when the supply of deer ran short, and the fox last of all-in fact fox-hunting, pure and simple, is of very modern introduction - the fox being looked upon, as no doubt he is, a perfectly worthless animal when captured, and our wise forefathers having an eye to the utile as well as the dulce, liked to have some good by their day's work. The fox at that time was destroyed as a nuisance and vermin, rather than preserved as he is at present-a run at a fox 
was rather the exception than the rule, and hounds hunted both fox and hare as stated above of the Cashelmore Hounds. Hunting itself is of very ancient origin-we read of it in the Bible. The ancient Persians taught their sons three things-" to ride, to shoot, and to speak the truth." Shooting in those days was a companion of the chase, not separated from it as at present, and the horseman who could get abreast of the quarry and bring him down with a well directed arrow from the bow, was considered the same as he who now takes the brush. Through the ages of gold, silver, brass, and iron, the Babylonian, Medo-Persian, Grecian, and Roman dynasties that have ruled the world, hunting has held its ground, and we see no reason why it should not continue to the end of time.

The present master of the Cashelmore Hounds, Mr. Thomas Beamish, was born in the year 1802 . By his friends he is still always called by the short and familiar name of Tom Beamish. He never remembers Cashelmore without hounds, and says they were there long before he was born. A labouring man, who lived all his life in the neighbourhood, and died at the commencement of the present year at the full age of a hundred years, said that the hounds were there long before his recollection. John Beamish, father of the present master, died in the

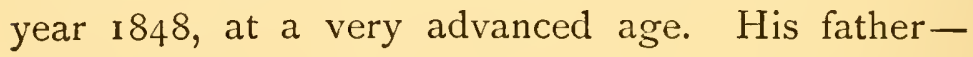
John also-died early in the century, and the present master well remembers having been out hunting with his father and grandfather; three generations together in the field with their own hounds.

John was the family name, and was borne by the 
eldest son generations back before those abovementioned. The present master was his father's second son. His eldest brother, John, died in the year 1836 , of scarlatina. Against all advice he would go hunting with the scarlatina on him, and it proved fatal. As the present master is always called Tom, so his father went by the familiar name of Jack Beamish: this was the old style of the country. Such were the masters; men, true and real sportsmen.

The huntsmen, of whom a record can be traced, are three-John, or as he too was called, Jack Bouig, and his son Patrick, or Paddy Bouig; and Denis Driscoll, whose sobriquet was "Dindy." How long the two former acted as huntsmen cannot be exactly ascertained, but it must have been for a very long time. The latter was within the writer's own recollection, and hunted the hounds for a period of between forty and fifty years. The writer's own personal recollection of the pack extends to that length of time, and having seen many huntsmen in the field, he can safely say that a better huntsman of his class than "Dindy" never followed a hound or carried a horn. He was equally good at running a fox hard and straight, or tracking the mazy windings of a hare, and always with his hounds. He acted as huntsman, for years after the death of the late master, in 1848 , until growing rather old for the business, his family emigrated, and took him with them to America. No other huntsman was then engaged, and for some time the hounds were hunted by the present master, occasionally assisted by a friend, until the present huntsman, his son-Mr. John Beamish-grew up to man's estate, and was able to take his father's place. UP 
to the year 1865 , the hounds were kept altogether by the Messrs. Beamish. In 1865 , they became a club pack, and have continued so since. The present huntsman, Mr. John Beamish, has hunted them since that date, and of late he has been assisted by his younger brother, Mr. Richard Beamish, as occasion required.

The hounds were originally all of Irish blood, but since they became a club pack a mixture of English was introduced, hounds being got from the Duke of Beaufort's pack, the Quorn and the Brocklesby, in England, and from the Muskerries, the Duhallows, the Curraghmore, the United Hunt (late Lord Shannon's), and Mr. T. G. Waters's pack in Ireland. There are still some grizzled hounds of the old Irish blood among them, and in hard running they still lead the pack. Some of the dogs are twentyfive inches high, and the average twenty-four. There are at present twenty couple in the kennel-originally. as stated above, they hunted foxes and hares, but for some years back, the club having stocked the country, they hunt only foxes.

Cashelmore, where the kennels are; is situated at the western side of the hill that bears its name. It is about four miles to the west of Bandon, a boroughtown in the county of Cork. On the top of the hill is a building of dry stone, with steps up to it. It was erected, in the year 1857 , by the present M. F. H., and a neighbouring proprietor, Mr. Zachariah Cornock Hawkes. Mr. Hawkes has been dead for some time. He was a highly scientific man and great antiquarian, possessing a vast collection of old Roman and other coins, and other such articles of vertu. The date, 
I $5^{\text {th }}$ August, 1857, and eye tangent of sea $32 \frac{1}{2}$ $+{ }_{7}^{1}$ th miles for vefn., 37 , are marked by him on the cairn. It is a conspicuous object from the surrounding district, and is called "The Peak of Cashelmore." From the Peak there is a most extensive view. On the south, is the ocean visible from the Old Head of Kinsale to Cape Clear, and the large American steamers passing to and fro can be plainly seen. On the west, north, and east are in view the range of the Dunmanway mountains in this county; Mangerton and the Reeks in Kerry; the Castle Oliver and Ballyhonra mountains in Limerick; the Galtees in Tipperary, and Knockmildown in the county of Waterford. All Munster can be seen except Clare. The mention of Knockmildown reminds the writer of the following story: On the summit, a Major Eels is buried. The Major used to say that, if buried in a churchyard, he was afraid at the resurrection he might have a dispute with some other tenant of the cemetery about a leg, or an arm, or some other bone. Up there he was safe not to have a bone of contention with anyone, they would be all his own. He was very fond of shooting, and on moonlight nights he would shoot on the mountain accompanied by his dog. His coffin was placed in an erect position, his gun by his side, and his dog was killed and buried at his feet. He left $£ 500$ in his will to carry out his instructions. The country hunted by the Cashelmore Hounds is not quite as extensive as the view from the Peak, but comprehends a good area. On the east, it is bounded by the river, the "pleasant Bandon, crowned with many a wood," sweeping in a graceful curve from the 
town of Innoshannon, by Shippool, with its church and old castle, the picturesque residence of $\mathrm{Mr}$. Thomas Herrick, and on by Kilgobbin and Ringfinnan (the latter the property of the M. F. H.), down to the harbour of Kinsale. The hunting-ground of the Cashelmore Hounds commences at the western bank of the river. The tide reaches to Innoshannon Bridge, and ships of large burden come up as far as Kilmacsimon and Collier's Quay. Thence to the south the country extends till it meets "torn oceans" roar," where it "breaks on its cold gray stones," at the cliffs of Garretstown, Courtmasherry, the Seven Heads, and on to Ring and the harbour of Clonakilty, where, treading to the north-west from the receding coast-line, it embraces the properties of $\mathrm{Mr}$. Bence Jones of Lisselane, Mr. Hume Townsend of Kilmeen, Mr. Gillman of Oakmount, and so on as far as the town of Dunmanway, or to any limit, indeed, in that direction, there being no pack to claim huntingground either there or at Skibbereen, a town many miles to the west of Dunmanway, which seems altogether out of the sporting world, as we do not hear of hounds, races, or anything of the kind connected with Skibbereen, a name that in the famine time became unfortunately notorious. In former days, indeed, there was a pack of hounds there, and when they were given up, the best of them were drafted into the Cashelmore pack, and capital hounds they were, as the writer, who often rode with them, can testify. At Castle Freke, to the west of Clonakilty, there is a pack of small hounds, harriers only, kept by Lord Carbery, so that, as far as the west is concerned, the district of the Cashelmore Hounds may 
be said to be boundless. To the north, then, it extends beyond the line of the Bandon river, over the property of Mr. Conner of Manch, and far to the north of that and of Kinneigh (where stands one of those mysterious round towers of Ireland), and Castletown, and embracing the Duke of Devonshire's extensive coverts at the north side of the river, joins the Muskerry country at Mount Pleasant. In breadth, from the sea inland, it is about twenty miles; and, in length, from Ringfinnan to the West, any extent.

The character of the country differs altogether. The west is wild, rocky, mountainous, and swampy. The east just the reverse: cultivated, smooth, nicely enclosed, and with good pasture-land and fair fences. The horse that could be ridden with safety over the eastern district, if only a good jumper, would break its own and its rider's necks in the western, if impetuous or a hard puller. Better hunts, however, are had in the western district. In the first place, if hounds get settled to their fox, it is very difficult, indeed impossible, for the best mounted man to override or interfere with them; and overriding hounds has scores of times spoiled a good hunt. As Nimrod, in his publication, "The Horse and the Hound," truly says: "One injudicious or hasty rider, by a single false step, has frequently spoiled the most promising run." In their western district the Cashelmore Hounds may defy any rider to do that. Let them once get settled to their fox on a fair scenting-day, and catch us who can, may be their motto.

The character of the foxes seems also to partake of the wildness of the district. The western foxes being given to run out straight and far, the eastern 
short and ringing. In 1876 the writer saw a run of this sort from Oakmount. Sixteen miles straight on and without a single cast given to the hounds, ending in a kill in the open of an old dog fox. The kill took place four miles to the west of Dunmanway, in open grass-land, at the side of Meelane mountain. During that run at times no man could get within a furlong of the hounds, and it was by a lucky turn that a single horseman got on terms with them when running full view at the fox, and was up at the death. That horseman can tell that the old Irish grizzled hounds were leading the pack and took the fox. Three others out of twelve were all that appeared at the finish.

The eastern district differs altogether. There a horse can go wherever hounds run. Good hunts are had there, too; but as a rule, as runs, they are not to be compared to the wild western ones. The meets in the eastern district are far better attended than in the west; from twenty to thirty being the average of the former, from ten to fifteen that of the latter.

The first-flight riders of the old day were John and his brother Robert Kenny of Kilmeen, the Rev. John Smythe of Castle Downeen, near Rosscarbery, James Gillman of Oakmount, Hill Gillman of Sandycove, Captain Adderley Beamish of Palace Anne, and his brother, Captain Sam (so-called), Francis Hingston, Fergus O'Connor of Fort Robert-a name not now mentioned for the first time-Jonas Sealy of Barleyfield, and his brother, Doctor John Sealy, Edward O'Brien, familiarly known as Ned O'Brien-a name as famous for hard riding in this district as that of Assheton Smith in his. A story is told of him as follows: 
Among the first-flight riders of the old day was the then Countess of Bandon, ancestor two generations removed from the present Earl. The hounds had found a fox at Kilbrittain, now the residence of Colonel Alcock Stawell -all former proprietors of Kilbrittain patronised hunting and joined in the sport. The present proprietor does not do so, but that can be accounted for by the fact that Stawell is an assumed name. Kilbrittain fell to an heiress. Colonel Alcock married the heiress and took the name, so that he is not the true blood of the Stawells of Kilbrittain, who were ever famous for love of the sport. The hounds had found at Kilbrittain and ran their fox hard to Kilmacsimon. Opposite Shippool the fox took the water, and swam across the estuary, the tide being fully in. The hounds close at their fox followed-and Lady Bandon unhesitatingly dashed in after them. Out of a large field the only one who dared to follow her was Ned O'Brien. He said afterwards that of himself he would not have dreamed of doing such a thing, but he was certain she would be drowned, and being a first-rate swimmer himself, he thought he might render her some assistance. Fortunately their horses carried both across in safety. Such were the first-flight riders of the old day, all long since dead.

Of those who were so and still remain the worthy master is to be named, who, now in his seventy-fifth year, still goes out with his hounds, and rides over a fence occasionally in a style that shows what he was in the hey-day of youth.

From his great knowledge of the country, also, he stills gets ahead in a surprising manner, and manages to be within hail "there," or "thereabouts," at the 
finish of many a run. A peculiarity possessed by him should not be omitted. It must be confessed that he shares it with his hounds. It is well known that the skin of the dog never gets heated like that of the horse; through the tongue all exudation of that kind passes off in the dog. A strange peculiarity of the master of the Cashelmore Hounds is, that no drop of moisture ever exuded through the pores of his skin. On the closest day, after the hardest hunt, when others were reeking, the writer has proved by touching evidence that every garment on the master was as dry as if it was held to the fire. That it exudes by the tongue cannot be added, though he certainly always was in that respect what Hector was

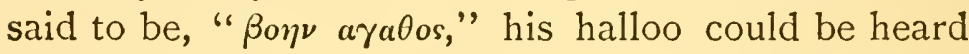
far and near, but nature had provided another safety valve. His head and face alone seem affected-they reeked doubly, and when he has taken off his hat, a smoke like that from a small furnace has issued from his head, and his face streaming, but all else dry as possible. Notwithstanding this peculiarity, which physicians would doubtless say was bad and dangerous, he has ever been a perfectly healthy man. Another peculiarity is, that there is a curious indentation in his skull, on the top of the head, rather towards the poll; any person feeling it would say, that the skull was certainly fractured. One day, when the hounds were drawing for a fox, his horse missed a jump and came down, giving him a "grasser" ugly to look at, but not hurting him in the least. Some of the field ran to him; and when the master had gathered himself up, a thought struck him-his hat had fallen off, and he placed his hands on the indenta- 
tion. Other hands were placed there at once, and, "oh! his skull is fractured, he has not an hour to live," was whispered from ear to ear. For a short time he left them in ignorance of the truth, then laughingly told them that the indentation was natural, and had ever been the same.

Mr. Francis Beamish of Killinear, a distant relative of the master's, is another of the old first-flights, but of late years he has given up hunting.

Among the best riders of the past day with these hounds two names should not be forgotten, those of the late James Lowe Holmes of Carrigmore, and Horace Townsend Poole of Mayfield, both of whom died in the prime of manhood within the last few years, and than whom no better sportsmen or useful country gentlemen could be found in any district.

The first.flight riders of the present day are Messrs. John and Richard Beamish, sons of the master, both of whom hunt the hounds as occasion requires; Mr. Daniel Conner of Manch, who at one time kept hounds of his own, but gave them up to join the Cashelmore Club; Mr. T. H. Poole, a nephew of Major Poole; Mr. Baldwin Sealy of Barleyfield, and his son Richard; Messrs. William and James Sealy of Burrin; Mr. Robert Travers of Timoleague; Mr. George Lamb of Barry's Hall; Mr. James Wheeler of Fort Prospect; Mr. J. E. O'Sullivan of Skeaf; Dr. Orpen Beamish of Enniskeane, and his brother, Mr. George Beamish; Mr. William Longfield of Church Hill; Mr. Francis Beamish of Kilmalooda, Mr. IVilliam Lombard of Hoe Lodge; Mr. Edward Gillman, who is well known as sporting both silk and scarlet; and Mr. Allcock Ottley. 
Having enumerated the gentlemen, the ladies should not be forgotten; indeed, by right they should have been placed first, but alas! the melancholy fact is that nothing in this world is right, all has gone wrong since Eve ate the apple. The first-flight ladies of the present day are, Mrs. and the Misses Travers of Timoleague, Miss Hosford of Barry's Hall, Miss Alice Beamish of Harehill, and Miss Conner of Manch.

The club was formed in the year $1865 ; \mathrm{Mr}$. T. Poole of Mayfield took the post of secretary and holds it still. He is a great favourite and thorough sportsman. Subscribers of the past day not now on the list were, Mr. James L. Holmes, Horace T. Poole, and Francis Beamish (all above-mentioned in the past); also General Beamish, Major-General Longfield, Colonel Teulon, Captain Cornwall, the late Mr. James Gillman of Oakmount, the late Mr. Walter Holmes of Carrigmore, the late Mr. Henry Hassett of Woodlands, and the late Mr. Francis Hurley of Bandon.

As subscribers of the present day, the name of Mr. Thomas Beamish of Kilmalooda, who acts as chairman of the business meetings, heads the list, which includes the names of all those gentlemen enumerated above as riders in the field; also those of Colonel Gillman, Captain Woodley, the Secretary, $\& c .$, altogether thirty names. The Cashelmore Hunt Races were got up in 1873 , in connexion with the club, and have been held yearly at their racecourse, at Knockbrown, since that date. 


\section{CONCLUSION.}

I pity the man whose heart never beat higher At the note of the horn, or the cry of the hound;

When the beauties all joined in a musical choir, Send up from the covert perfection of sound.

Now when night has set in, and the wild winds mourn ever, Beside the bright fire, I love to think o'er

Those days that have passed that will come again neverThose days that I spent with the old Cashelmore.

Yes, I think of the day where the Cashel Peak towers Two foxes divided the blood-loving pack, And how the scent lay, while the southerly showers Poured down on the field when we met at Moulbrack; And where Timoleague's Abbey stands over the water, And Umera's woods kiss the silvery wave.

How they raced through the pastures determined on slaughter, While Reynard his brush was determined to save.

Good luck to them ever, stout foxes to lead them From Carbery's hills to sea girt Barryroe;

Old Irish blood ever, so long may they breed them A true hunting pack, and a good one to go. Aye, my horse has grown old and his rider grown older, And few may the days be that linger before;

But my heart is as warm though my old limbs are colder, As when first I rode straight with the fast Cashelmore.*

"Elfin."

* I am indebted to one of the best sportsmen in the south of Ireland for this history of the Cashelmore Hounds. 


\section{CHAPTER XII.}

THE WVXFORD HOUNDS.

THIs pack was established nearly a hundred years ago, by Colonel Pigott of Slevoy Castle, as a private pack, in conjunction with gentlemen residing in his neighbourhood. In the year 1810, the Wexford Hunt Club was formed, and Colonel Pigott became master, and continued to fill that office till he resigned in 1839 ; then his son, the late Mr. G. P. Pigott, was appointed. In 1841 , Mr. James Harvey took the horn, and, after one year's mastership, was replaced by the present master, Mr. D. V. Beatty, in conjunction with Mr. St. George Deane, who hunted the country for one season, at the termination of which Mr. Beatty took the onus on his shoulders, which he has borne continuously ever since. He hunted the hounds himself till the close of the seasons $1875^{-6}$, when, from various causes, he announced his intention of keeping a huntsman. The hunting district is very extensive; about thirty-three by twenty-three miles. It is a very difficult country to ride over; you require a very well trained horse. It is for the most part flat, with undulating hills, and obstacles of all descriptions are to be met with. The territory includes all the county Wexford, south of that hunted over by the Carlow and Island Hounds. It is bounded, south and east by the sea, on the west by Carlow, and on the north by 
the Carlow and Island country. The country is quite capable of four days a week; foxes are numerous, and the coverts mostly of gorse, were, with few exceptions, planted by Mr. Beatty himself, and are situated at convenient intervals, and in the most favoured localities throughout the entire district.

The pack combine great power with rare hunting qualities, which the nature of the country requires. There are generally from forty-two to forty-five couples of hounds in the kennels; the dogs averaging twentythree inches, and the bitches twenty-one and a half inches in height. They are, undoubtedly, a very well selected lot, bred exclusively, under the master's own supervision, from the best English kennels; especially Lord Portsmouth's, who has a large property in the county, and has done much to benefit the pack. Indeed, the Wallope blood preponderates, and is said to be recognisable by those who know it in the south of England, where his Lordship has been a M. F. H. for so many years. In Ireland he is only known as a most liberal landlord, who makes up for being an absentee by a noble generosity in his relations with his tenantry, one of whom characteristically said of him, "Faith, he's a mis-named man; Wallope, indeed! faith, it ought to be Walloper."

During his long tenure of office, Mr. Beatty has gained extreme popularity. In April, 1872, he was presented by the leading gentry of the county, and many of the most respectable farmers, with a very costly service of plate and the following address:-

"We, the members of the Wexford Hunt, sporting friends, and other residents of this county, desire to convey to you our admiration of your character as a sportsman, our respect and esteem for 
you as a country gentleman and a friend; and to beg your acceptance of the accompanying Service of Plate, in remembrance of your most efficient services as a master of foxhounds for the past thirty years.

"Your arduous duties-always self-performed in their minutest details-have each succeeding year resulted in sport, so constantly increasing, that we have learned to regard with profound admiration a master to whom we owe so much.

"The difficulties you have to contend with in this country are well known; distant meets and doubtful scents are drawbacks, successfully to contend with which require the constant exercise of gifts, that we believe you to possess in an eminent degree, namely, patience, perseverance, and an indomitable love of foxhunting.

"As a country gentleman, you have at all times endeavoured to promote our social and material interests by the development of the resources of the country, by improvement in breeding of horses and stock of all kinds, while your example as a practical farmer must be considered as of great value. Ever at home, always kindly and courteous-dispensing a liberal hospitalityyou have reached to a pinnacle of local and personal importance only to be obtained by the most gifted minds, and have secured to yourself a host of friends, whose wish that you may enjoy a long and agreeable life, we here venture to express.

"We have taken the liberty of asking that Mrs. Beatty would do us the pleasure of accepting a Gold Repeating Watch and Chain, as a small souvenir of our regard for her, and in gratitude for the numberless hospitalities which most-if not all-of us have, from time to time, received at her hands.

"In conclusion, we trust that your thirty-first season as master, now inaugurated, may be as prosperous as those which have preceded it; and that you may long continue to hold the horn of office to your own credit and to the advantage of fox-hunting.

"Signed on behalf of the Subscribers,

"William Bolton, Chairman."

Mr. Beatty is a first-rate judge of horses and hounds: and, although he rides fully sixteen stone, 
generally sees as much of the good runs as any of the welter weights who participate with him in the pleasures of the chase which he so keenly enjoys. 'The hunting days are Mondays, Wednesdays, and Fridays. George Sheppard hunted the hounds during I876-7; he then left, and Mr. Beatty now hunts them, ably assisted, when the pace is very severe, by his son-who is a very good horseman. Joseph Turpin, who had been kennel-huntsman to the Galway Hounds, is now acting as such at Borodale. He is an excellent servant, and I may say the same of the Whips, Philip and John Morrisey, who have been in the employment of Mr. Beatty for many years.

The late Mr. Bolton of the Island, county Wexford, kept two packs of foxhounds, and hunted the Island country for upwards of thirty years. He was an essentially popular man, and an ardent sportsman. In $\mathbf{1 8 4 2}$, a superb specimen of Irish manufacture was presented to him by the gentlemen who were in the habit of hunting with his hounds. It consisted of a large massive waiter, weighing upwards of two hundred and seventy ounces, with a representation of a foxhunt, in four compartments, embossed from a flat plate of silver in very bold relief. This beautiful piece of plate bore the following inscription :-

\section{"Presented to}

IVilliani Bolton, Esq.,

By the friends of the Island Hunt,

in testimony of their regard and esteem for the very liberal and handsome manner in which he has, for upwards of thirty years, kept, at his sole expense, two packs of fox-hounds in the county of

Wexford.

April 29th, 1843." 
Mr. Bolton kept the hounds till his death, in 1853. His son, celebrated in the annals of shorthorn breeding in Ireland, not being able to devote as much time as he considered necessary to hunt the country, gave the pack and country, conditionally, to the Earl of Fitzwilliam, who induced Mr. Watson to take them; he has ever since hunted the district. Mr. Bolton is a very liberal supporter of the Wexford Hounds. 


\section{CHAPTER XIII.}

THE LIMERICK FOXHOUNDS.

I HAVE not been able to obtain particulars as to the ownership or performances of the several packs of hounds which were, undoubtedly, employed during the last two hundred years, in the pursuit of deer and fox in the county Limerick. Tradition has it that the noble families of O'Brien and Fitzgerald (knight of Glinn), and that of Colonel Lloyd, sustained venatic science; but I must confine myself to authenticated particulars. I can assure my friends that my brief history is perfectly accurate. I regret that I cannot give more lengthened details, and hope that this chapter may, with all its shortcomings, prove interesting to my readers, and receive at their hands a lenient judgment for,

"When good will is shown, though it come too short, The actor may plead pardon."

Somewhere, about 1828 or 1830 , Mr. Croker of Ballinagard, gave up a pack of hounds, with which he hunted hare, deer, and fox; it was a scratch concern at best. The hunting gentry of the county then determined to form a pack for fox-hunting only, and the mastership was undertaken by Mr. George Fosbery of Curragh-bridge, about the date above- 
mentioned. Sir David Roche, father of the present master, and Colonel John Vandeleur, of the roth Hussars, his uncle, built kennels, stables, \&c., near Croom, where the hounds were kept, with the exception of one season, until I86r. Mr. Fosbery, dying about the year 1845 , there was a committee formed of Mr. Frank Fosbery, his son, the Rev. Thomas Croker of Croom Castle, and Mr. Edward Green of Greenmount. The trio kept the country for two seasons, until 1847 , when Colonel Dickson came to reside at Croom Castle, and took the hounds, having for huntsman Fred Turpin (afterwards killed with the Braham Moor Hounds); he continued in office two seasons, when they were taken by the Hon. Fitzmaurice Deane, and removed to Springfield Castle, he only hunting the west of the river Maigus. This arrangement only continued for one season, and the hounds returned the following year to their old kennels, near Croom, under the management of the former committee, which continued until 1853, when Mr. Green took sole mastership until his death, in I $86 \mathrm{I}$. The country then bid fair to become vacant, as there was but a scant subscription, a wretched pack of hounds, consisting of twenty-three couple, the country in very bad order, as regards coverts, and hardly a fox to be found. Under these conditions. Mr. Roche, as he then was, came forward and offered to hunt the country with his own hounds, and lay out the subscription on putting the country in order. $\mathrm{He}$ got together a tolerable lot of hounds, being greatly assisted in so doing by Mr. Tom Pain, then master of the South Wilts, now partner in the firm of 
Messrs. Tattersalls, and also by the late Henry Greaves, the master of the Vale White Horse. Mr. Roche turned out the first season seventy-three brace of foxes, and had not a run to speak of during the year, as they did not know the country, and were mostly killed in covert. From that time matters began to mend, and now the country is in good order, and is hunted three days a week, with forty-five couple of hounds in kennel. There does not exist a sportsman more attached to foxhunting than Sir David. He has studied venatic science in its minutest details, and, although he rides fully six. teen stone, he stays with his hounds, no matter how difficult the country is, or how fast the pace. He takes to the work con amore, and his affability, kindliness of heart, and many other estimable qualities, have made him a "warm favourite." His efforts to ensure sport are ably seconded by many of his countrymen-notably, Mr. John White of Nantnean, in the western district; Captain Edward Croker of Grange, in the east; and Mr. Harry Croker of Ballynagard. Foxes are well preserved by all the large game preserving proprietors, viz., Earl Dunraven, Lord Clarina, Lord Emly, \&c. Sir David hunts his own hounds, assisted by John Kennedy, who has now lived with him twenty-two years. The hounds are kept at Sir David's own place, Carass, having a cubhunting kennel at Darragh, Kilfinnin, where they spend six weeks every autumn.

The two following articles were published in the Irish Sportsman. They were written by a noted sportsman, who resides in Munster. As I have been informed that they are extremely accurate, and 
were read by many with great interest, I republish them :-

"I have read with much interest, from time to time, in the Irish Sportsman a history of the packs of foxhounds in some of the celebrated hunting districts of this country, and I have been rather surprised that no one has undertaken the task of laying before your readers the various phases through which the Limerick Hunt (now and for years back so celebrated) has passed. It may be considered presumptuous on my part to undertake the task, but as those who knew it in its pristine days of glory are now fast passing away, I hope I will be excused for trying to leave a record of some of the many scenes of intensely deep interest to the sportsman that I have a recollection of, and in many of which I was a participator. My first recollection of the pack dates from a very early period, as I was very little more than a boy when the kennels at Croom were built, before which time the hounds were kept at Riddlestown Park, the residence of the then worthy master, Mr. Gerald Blennerhassett. The first huntsman I can remember was Ryan, who, in a very short time after his arrival at Croom, fell a victim to the first visitation of that dreadful scourge, Asiatic cholera, and he, poor man, was, I believe, the very first that succumbed to it. The hounds were then managed by the late lamented Mr. George Fosbery, who, though a little rough in manner, was as popular a master as ever carried a horn. During the time that he was proprietor of the Castle Oliver property he always took the hounds there for cub-hunting, and the value of the locality for such purposes is proved by the fact that the present worthy master, Sir D. V. Roche, has rented Darah, quite near Castle Oliver, for the same sporting purposes. Dan Ward was whip to the hounds at Riddlestown, and for some time after their arrival at Croom; and when hunted by Ryan, John Frawly was whip. Ryan was succeeded by Pat Connell, than whom a better man never threw in a pack; the whip was Thomas Herlihy, stepbrother to Pat. Pat had a happy knack of knowing when there was to be a good thing, as by a signal with which some of his friends were acquainted, he indicated that they were to look sharp, and take and keep, if possible, a" good"place. This signal consisted in the simple act of wearing the peak of his hunting-cap in a different style from that usually adopted, its position being 
over his poll instead of over his forehead. This signal, whether proceeding from Pat's superior knowledge of hunting or from mere surmise, was very seldom a false one, and was intended more as a gentle hint to those members of the hunt who stood highest in his favour than as a display of superior knowledge, as for a long time it was not known to the uninitiated. Poor Pat, after many years of faithful service, unfortunately fell a victim to the baneful influence of 'that destructive fluid' that has been the ruin of so many of his class, and, indeed, of many other classes connected with horse-flesh; he had to forfeit his position, and after a few years of hard struggling, depending for some time mainly on the charity of those who knew him in better days, he died in the Croom Workhouse.

"I will not spin out this yarn to the length that would be required in describing the history of the hunt during its course subsequent to the death of Mr. Fosbery in the various stages through which it has since passed, but will, as memory serves me, give you the names of those members who were then not only conspicuous for their position as supporters of the hunt but celebrated for the place they always took in the hunting-field. I begin with the master of the pack, Gerald Blennerhassett; his brother John and his sons Gerald and William (both still alive), the Knight of Glinn (grandfather to the present knight), and also his son and successor to the title (and father to the present knight), George Fosbery (subsequently master) and his cousin George, a quondam resident in Kerry, or, as they were popularly called, Black and Red George. There are feats of horsemanship on record in connection with the names of these two gentlemen that are, I believe, almost without parallel, and would appear incredible if they were not well authenticated.

"If I did not confine myself to the names and residences of the members I fear I would have to write to such a length as would make you decline any communication from me, or, at least, abridge it in such a way as would not leave it an o'er true tale. The list may appear a matter of dry detail to those of the present day who do not know what the position was, both territorially and in a sporting sense, of the good men and true whose names I give. Next after the Fosberys I will name Captain Hugh Massy, one of the truest and most popular sportsmen connected with the hunt; he kept his hunting establishment at Ardagh, in the west of the 
county. His son, Hutchinson Massy, was a member of the hunt, I believe, up to the time of his death, and lived at Brook Lodge, near Newcastle West; Eyre Massy, the captain's brother, who lived at Glenville and Glanduff; Ion Studdert of Elmhill; Thomas H. F. Royse of Nantenant; the thorough sportsmen, George Lake, the Locks of Newcastle, Bryan Sheehy, and the Crokers. John, then of Croom Castle, subsequently of Ballinagarde, grandfather to Henry Chester, had three brothers clergymen, the Rev. Edward, incumbent of Croom (known as the 'long minister,' being about $6 \mathrm{ft} .4 \mathrm{in}$. in height, notwithstanding which, and being near-sighted, it was not easy to beat him over a country), the Rev. Thomas, who succeeded his brother at Croom Castle, and the Rev. Robert, who was incumbent of Atlacca, in this county, as keen a sportsman and as amiable a gentleman as ever temporarily laid by the gown to don top-boots. There were two half-brothers, Henry of Drumkeen (still alive), and Captain Croker, living near Mallow; Michael, Jerry, and James Shine, fathers and uncles of the present riding men, who are true 'chips of the old blocks ;' Joseph Gubbins of Kilfrush and George Gubbins of Miltown, father and uncle to the captain, both heavy welters, who were always well placed, having the right sort between their legs; Thomas and Henry O'Grady of Grange, maternal uncles of Captain Croker, the present occupier of that nice residence; Captain John Lowe, then living at Ballinanty, near Bruff, now at Sunville, near Kilfinane; John Bouchier of Baggottstown, still alive, and one of the best authorities on turf matters to be found, excepting, of course, the keeper of the Match Book; the Hon. and Rev. William O'Grady of Rockbarton, uncle of the present Lord Guillamore; The O'Grady of Kilballyowen; Ryan of Scarteen, father to our worthy sub-sheriff, who, with his brothers, preserves the sporting proclivities of their father and grandfather, old Thomas Ryan, once proprietor of a first-class pack of beagles; Joseph Gubbins of Ballincollon, whose cheery shouts and jolly manner would cause the most desponding to forget his troubles; Richard and William Ievers, brothers to the worthy proprietor of Castle Ievers. The county contingent will wind up with the name of one who, though last on the list, was ever amongst the first in the exhibition of all the traits that are essential to the position of a first-class sportsman, being a tip-top horseman, proprietor of one of the best hunting and racing studs in the county, many of his horses having frequently borne his colours to victory, 
and also for many years proprietor of a first-class pack of harriers, John Westropp of Attyflinn Park. I will head the city contingent with the names of Ralph and John Westropp, cousins to the aforesaid John, the second being father of Ralph, of coursing celebrity, and Captain John of the County Militia. The other citizen supporters of the hunt were Captain Jervis (called the 'Rake' in George Lake's celebrated hunting song), the Verekers, James Peacock, Ralph Jameson, the two Spaights, James (our present worthy Mayor) and William, who for some time kept his horses at Carass; the Steins (contemporaries of the Spaights), and James Kelly, for some time MI.P. for the city, but who kept his hunting establishment at Ballinanty, near Bruff. There was also a fair sprinkling of the military from the Limerick garrison. Clare sent the two Carneys-Matt and poor Denis, of steeplechase notoriety-the M'Mahons, and some others. The Cork men, who used to come more frequently, and in larger numbers than at present, were James Russell of Mount Russell, father of P. J. Russell ; Michael of Glenmore, father-in-law of MIr. "Appleton,"* and father of the owner of Country Lass; the Harrisons of Castle Harrison; the Bruces, Crone of Bybloss ; Lord Doneraile, Brazier of Ballyellis; the Barrys, Tom Freeman, and some military men from Buttevant, also MIr. Stawel.

"If I were at all to allude to the splendid runs of those days, which were not by any means few and far between, I fear that my enthusiasm would carry me to such a length as would make you lose all patience, and tempt you to throw the whole production into the waste-paper basket. My writing this account was suggested by the circumstance of my being driven to my wit's ends for a means of getting over one of the many wet and dismal days with which we have been visited during the last three months. I venture to send you my lucubrations anent fox-hunting, for though witnessed on a day very little less gloomy than night they are really the thoughts suggested during some sleepless hours, the absence of the influence of Somnus being mainly due to inability to take outdoor active exercise, owing to the frightfully inclement weather that has so long prevailed. Should you not feel bored by them I would continue to give you from time to time an outline of the history of the hunt through the various stages of its career subse-

* Mr. John Hutchinson. 
quent to the period to which this communication has special reference. The names of Edward Green and Frank Fosbery are pre-eminently entitled to a place among the many other good men whom I have enumerated, but as my intention was to connect those with the period during which MIr. Green was master, I kept them in reserve to mention them with that particular time. I will also name some few that I fear I have passed over in this record, but who I hope to do justice to in my next communication.

\section{"ONe who was often with Them.}

"P.S.-I see by a short paragragh in Saturday's Irish Sportsman that you promise to give in your next issue the account I sent you of the history of the Limerick Hunt, and finding now that I wrote it in rather a hasty manner, from the causes stated, and as a considerable lapse of time has occurred since the period with which it was connected, and many names which should be added to those that I have given escaped my memory, I hope you will, if not too troublesome, kindly supplement my first list with the additional names that I now give; their support of the hunt, and their qualities as sportsmen, entitle them to a place amongst the others. The four brothers Parsons, George, Francis, John, and Godfrey, all cousins to the Fosberys, and trained from their infancy to the glorious pursuits of the hunting-field, their father having long since kept a pack of harriers; Gerald Fitzgerald of Ballinvira, true to his position of sportsman and squire, proprietor of a nice property, residence, and deer-park, until, like many others, victims to a change of times, he fell from his high estate; Hugh Massy, then of Stagdale, father-in-law of our worthy master, Sir D. V. Roche; Sam Harding, uncle to Lady Roche, a slight, hardy young man, living at Cherrygrove, who on his horse, Cigar, would give a lead to no man, except to those entitled to it by the etiquette of the hunting-field. Francis Drew of Drewscourt; Jeoffrey Browning of Carass Court, who was married to Sir David Roche's aunt; his son, Thomas Browning, who married Miss Gubbins, sister of the Captain; John M. Cantillon, then of Castleroberts, father of the present hunting men; George Furnell, whose sons still keep up the sporting character of the family; Henry Lyons of Croom House, uncle to the present owner of that establishment, who lived a bachelor, and was a particular favourite. As well as I remember the late Sir David Roche was for some time treasurer to 
the hunt, and always one of its best supporters. William Cox of Ballynoe; John Cox of Ballyneale; Rev. John Croker of Fort Elizabeth, a light weight, good to go: Fritz Croker of Grange: Eyre Powel of Ballymurphy; Gibbos Fitzgibbon of Ballyseda; James Peacocke of Dooneen; Edward Crips Viller of Kilpeacon, and John Crips of Cahernom. These last two names take the mind so far back as to make the men of the present day express astonishment that there are still alive some of the contemporaries of those old fox-hunters. But as your correspondent from the moment he could admire a hunt, in connection even with pedestrianism, was always deeply interested in all its accompaniments, the impression left on his memory has been almost indelible. Many of the hunting men of the present day have never seen those mentioned, and, perhaps, some may not even have heard the names of some of those in my list. Many of them have long since passed away, and their positions are now occupied by strangers-men who take very little interest in what was to the departed a source of the greatest delight. I am happy to say that their successors in the hunting-field are not less true to their position, and that the hunt has lost nothing of its former fame. As it is at present graced by the presence of the fair sex, so was it then, conspicuous among whom was the present Lady Humble, then Miss Fosbery; Mrs. Major Smith, nee Miss Spaight; and Miss Mary Creagh (after whom Captain Hugh Massy called his celebrated mare).

$$
\text { “February 5th, 1877." }
$$

"As I infer from the complimentary remarks which appear from you at foot of my last communication that it has in some degree interested you, and as you have expressed a wish that I should continue my narrative of the various interesting circumstances connected with the Limerick Hunt, I most willingly resume my observations relative to that sporting institution. I will now introduce on the stage-or rather on the Turf-the names of those who, though for a portion of the career of the 'veteran hands' whose names I have sent you, they were in the position of the junior division, are now, in consequence of the sure advance of time, while still in the prime of life, with a few exceptions, entitled to be recognised as the senior division of the members of the present hunt, and most worthily emulate their predecessors in all the glorious qualities that constitute a thorough sportsman. 
Alas! that the survivors of that 'veteran band' are now reduced to very few indeed; but, though long since compelled to abandon the hunting-field, they have, I am sure, preserved-mentally at least-all the enthusiasm of younger days. I have been endeavouring to bring before my mind's eye the names and present position of those who constituted what I will designate as the 'old guard,' and I regret very much to say that I cannot count up more than the few whose names I give, but who, I am sure, are quite willing to adopt the old saying, 'we have had our day,' and who, all being nearly entitled to the venerable designation of octogenarians, are quite willing to wish their successors joy of the sport in which they were for such a length of time participators.

"I will begin with the name of that thorough sportsman, John Bouchier of Baggottstown, still hale and hearty, and surrounded by a family of whom any parent might be proud; Henry Croker of Dromkeen is the oldest, I believe, of the number who, being long out of the saddle, are still strong, though much less active than formerly, from the effects either of gout or rheumatism. $\mathrm{He}$ tries to compensate himself for the loss of former enjoyment by the discharge of his social duties, both as a landlord and domestically, in such a manner as to entitle him to the respect and esteem of all with whom he comes in contact. Then comes Captain J. Low of Sunville, in the same position physically as Mr. Croker, and entitled to the same meed of praise for his private qualities; Hugh Massy, now living at Ballinacurra, near Limerick, who has for many years been patiently reconciled to one of the greatest physical afflictions to which our poor humanity is subject; Captain Ralph Westropp, now and for some time residing at Kingstown, hale and hearty, and whose absence from this county is deeply deplored by all who had the good fortune to be counted among his friends. While living in his pretty cottage at Athlacca he dispensed the hospitalities of his establishment in princely style, and his charities were indiscriminate and unbounded. May he live as long as all his Limerick friends would wish. J. Gubbins of Ballincollon, who, in point of age, is, I believe, entitled to priority, still preserves all the glorious qualities of a veteran sportsman, and, like Uncle Toby, feels a special delight in fighting all his battles over again. The last I will name, and I am almost sure the last that could be named, is William Cox of Ballynoe, who of all mentioned wears his age the best, as proof of which, and of 
the possession of that stamina that is one of the attributes of a sportsman, he within the last twelve months has taken to himself a second wife, with whom I pray he may spend many happy years.

"The glorious career of the veteran band whose history I have just closed will, I hope, serve as a bright example to those whose names I will now give, and who were among what I will call the men of the second era of the hunt, some of them having been out when the career of the veterans was approaching its close. I will begin with the name of Edward Green, who, during a very great part of both eras, was one of the best and most faithful of the Club's supporters, and who even for a period (though short), when it was at its lowest ebb, was thoroughly true to it, and who, during all the time that he was a joint manager, was well supported by some other true friends of the club, not the least of whom were the Rev. Thomas Croker, then residing at Crovin Castle; Colonel Dickson, subsequent occupier of the castle; the Fosberry family, the brothers Stein of Limerick, and others. Mr. Green was, I believe, for some time after the death of Colonel Dickson sole manager, and discharged the difficult duties of the position in the most amiable manner, and no master ever lived that enjoyed more deserved popularity. Next we have Frank Fosbery, son to the father of the hunt, as he deserves to be entitled, as good a horseman and possessed of the same good qualities as the sire, as fearless a rider as ever handled a bridle, and, though obliged to wear an eyeglass in the peak of his hunting cap, does not know danger; his brother Tom, much Frank's junior, though now exhibiting in his upper storey a little of the Oxford mixture, still true to his position, and, albeit a somewhat venerable parent, able and willing to keep his place as of old. James Spaight is well entitled to the appellation of evergreen, though the presence of that colour on his upper surface, which is so indicative of winter, would make the appellation of evergreen paradoxical. $\mathrm{He}$ is entitled to the position of senior of the lot whose names I am now giving, and I am sure he will not feel annoyed at the position I assign to him, as he is well able to put some of the aspirants to hunting honours of the present day to the blush. His brother William has abandoned the hunting-field ever since he became proprietor of that splendid and picturesque residence, Derry Castle, on Lough Derg. I will now take a long 'skip,' and connect my notes with the western portion of the county, and begin with the 
name of Jonathan B. Massy of Glenville, one well entitled to a conspicuous place as the son of Eyre, whose name appears in my last communication to you, and also, as nephew to the Captain, and as both of those are well entitled to the popularity they enjoyed so also is he whose name I now give. He keeps a very nice pack of harriers, hunts twice a week, and in the hunting. field is never better pleased than when his friends express themselves satisfied with the day's sport. His greatest wish is to afford his pedestrian friends a pleasant day, and as a consequence he has not to complain of the scarcity of game that prevails in other districis. In connection with the same quarter I will give you the names of George and Arthur Studdart, who, though not for some time putting in an appearance, were, when on the turf, the very beaux ideals of what true hunting men should be. Doctor Pierce of Newcastle West, though death on a fox, contrives to have that awful word as seldom connected with his patients as falls to the lot of any other disciple of Esculapius. William Harnode Massy of Glenwilliam Castle has long since passed away, and his property into the hands of the stranger; and his brother-in-law, Richard P. Power of Ballinakill is as fine a sample of humanity as could be seen, and with a heart in proportion to his person, perhaps too big, to ensure to the owner the continuance of that worldly position which those continue to maintain who possess a smaller organ but a much larger share of prudence. Lest I may be too profane, I will introduce a member of the Church, the Rev. Grantley Shelton of Rossmore, one of the best black-coats that has ever been connected with the hunt, and who, whenever he had the opportunity, either by the proximity of the meet or the passing by his place of the members on a hunting day, was a most liberal dispenser of the hospitalities of his pretty residence. His brother, Major Shelton, then resided at Bruree House, the present residence of the worthy master of the Limerick Staghounds. The Major was a great favourite and an enthusiastic foxhunter, for though obliged to attend to his duties in connection with the county regiment he contrived to have as many days with the hounds as possible. I will give after the Sheltons the names of the two Coyners-Charles, the amiable proprietor of Castletown Conyers, and his brother, Grady F., of Liskennett, the chief promoter and staunch supporter of our now celebrated annual race meeting at Banogue. Next come the two Gubbinses- 
Captain Stamer, who requires no eulogy from me (and I am proud to say is, to the delight of the whole country, recovering from the effects of the fearful accident he met with some time since), and his brother John, who is, very justly, a high favourite with all who know him of every class. His hunting days are looked forward to with the greatest delight and anxiety, as he scarcely ever has a bad day, and is never in better humour than when all who assemble at his meets are satisfied. His arrangements for taking out two animals in his deer-cart evince his anxiety to please all parties. $\mathrm{He}$ is also a great favourite with the farming classes, as he takes the greatest pains, both by a caution on his cards, and by personal exertion, to save them from all unnecessary trespass. His connection with the Banogue Races also adds very much to his popularity. I may next mention the two Ryans of Bruree-Henry, now an absentee by emigration, and Kenny, still true to his position, and who, though deserving to be classed among the welters, is always in the first-flight either with the fox or staghounds. I fear I will have in this communication to resort to the same mode of describing the other members of the hunt connected with the period I am now dealing with as I did in my last communication, and give them to you by name only, without any descriptive accompaniments, though they are all entitled to a favourable word as regards the merits and good qualities which they possess, and have always exhibited.

"As the residences of the four last-named are in the eastern part of the county I will take from that quarter also the names that follow:-Henry Jones of Abbeyville, younger brother of the two whose names I have given in my first list; James Shine, formerly residing at Rockstown Castle; his brother Roger, now residing near Cashel; Michael, who lost his life under such melancholy circumstances on the Limerick racecourse a few years ago; and their cousin Jerry, residing at Ballymacruse. The lastnamed and James are still true to their position in the huntingfield, and able and willing to uphold their character for good horsemanship, for which they have been so long famous. Living quite close to the residence of the last-named is one who has made for himself a name as a true sportsman not less distinguished than the best of those who appear before him, and who, in his own respectable and independent sphere, has upheld with infinite credit the character of his class-I mean Joseph Hannan of Inch St. 
Lawrence, than whom a keener sportsman or better fellow is not to be found in the county. Steady to my purpose and to locality, I will name $\mathrm{F}$. Kelly, son to James, whose name I have given you among the veterans. He cannot claim the same long connection with the hunt that all the others can, as during a great part of the time I speak of he resided out of the county, I believe on his father's property at Cahercon, in the county of Clare; but as he has been for some years connected with the Hunt, and keeps, and can steer well, a few good ones, I could not well omit his name. Not far from the same locality, but lying a little more to the East, is the country that has produced two right good men, the Ryans(John, our worthy sub-sheriff) and his brother, whose Christian name I do not know; the former one of the best men out, and whom nature specially formed as a perfect specimen of a riding man-average height, straight as a whip, and not an ounce of waste flesh about him; as a rider, he is cool and steady, always well placed, and never incurs the anger of the master by rash riding.

"Trying back towards home I will name Captain Edward Croker of the Grange; though heavy he rides steadily and is well placed, is never absent from the meet, and a dispenser of princely hospitality to all comers whenever the meet takes place in his neighbourhood and on all other occasions. He is the son of the Rev. Robert, whose name and character you have in my last communication, and is the nephew maternally of the two highly respectable gentlemen who formerly occupied the splendid residence of which he is now the proprietor. I will simply give you the name of his neighbour and relative, H. S. M. Croker, as any eulogy of mine, or any description of him, would be simply ridiculous and presumptuous, as his fame as a sportsman is known far beyond the limits of this county. Still pursuing my western cuurse, I name James Bennett of Fedamore (son to the Rev. James), who has been a long time connected with the hunt, and is entitled to a first-rate position. $\mathrm{He}$ is among the light-weights, but always with a horse in proportion, and sure to be there or thereabouts-a quiet, amiable fellow, and much and deservedly liked. William R. Croker of Alston, who, though long ago discontinuing the actual working part of the interesting business, still looks after it on four-wheels with as much interest as of old. Immediately near Mr. Croker's residence there formerly resided as good 
a fellow as any country could produce, Captain Hamilton Jackson, residing at the time I speak of at Attyflinn, subsequently in a very nice castellated mansion, erected in connection with one older, at Fanningstown (now the property of Sir D. V. Roche). The captain, I believe, now resides somewhere in the neighbourhood of the metropolis, and his absence from this county is much regretted. I should next, according to the order in which I am proceeding, name Sir D. V. Roche, but as I could not be satisfied with an individual reference (his claim to a special remark and to an enumeration of his many good qualities, both as a master and in his private capacity, entitling him to a more extended notice) I will reserve his name for a front place in my next communication, when I intend to introduce the names of all the junior members of the hunt, calling the present the third era in point of time and succession of individuals, and I am glad to say that there is no falling off in point of performance. Next neighbour to Sir David Roche is Mr. H. Lyons of Croom House, a staunch supporter of the hunt, and whose portals are always open to all who pass by on hunting days. He had two brothers, long since dead, having died just as they arrived at manhood. They were enthusiastically devoted to the manly pursuit of the chase, and as their qualities were of the most amiable kind the death of each was generally and deservedly regretted. Pursuing a northern course, and approaching the city, I give you the name of the Hon. Hugh Massy, brother to Lord Clarina. He requires no praise at my hands, as in every sphere of life, both as a sportsman and in connection with his general position, he has secured the esteem and best wishes of all who know him of every class. The city has sent two good men (exclusive, of course, of many very good juvenile aspirants, whose turn is to come), William Sidly Cox and Major Pratt, many years a constant attendant, and one of the right sort for position. Mr. Cox is son to a man who, for a great many years indeed, and during its best days, was a most enthusiastic follower of the hounds, and took a first-class place in some of the best runs of the olden time. The last I can name in connection with the city and with the eastern division of the county is the Hon. John Massy of Hermitage, between Castleconnell and Limerick. I have only to say of him that he was the very personification of amiability, and exhibited even as a sportsman the same gentleness of demeanour that he did in every other position, keep- 
ing a good place, and in such a quiet way as made it appear that he went out for sport and not for display.

"I must transport myself again to the West, and give the name of that true sportsman and genuine supporter of the hunt, John White of Nantenant, near Rathkeale, which was formerly the residence of Mr. Royse, whose name has already been mentioned. Mr. White requires not one word of praise from me, as he stands A I in connection with the annals of the county. He is the Fidus Achates of the present worthy master, and is scarcely ever absent from the meet. $\mathrm{He}$ is truly one of the mainstays of the hunt. Two good fellows are now dead who were always recognised as the very essence of good sportsmen, Captain Davenport of Ballinacourty and Mr. Carroll Naish of Ballycullen, whose melancholy death was caused by a most trivial accident. Edward Langford of Kilcosgriff has a long time retired from the hunt, but was a firstrate man to ride in his day.

"Another good man in the same locality, of the same standard in point of age and good riding qualities, is Edward W. Morgan of Ballynolan, who still likes a good day's sport as much as ever, and can stand the hardships of a severe day, even in the worst weather, as well as of old. Close to him lives a sporting coroner, who, though often out, is, I am quite sure, never impelled by an anxiety for a job, and who, I am convinced, rejoices at his want of success in that way as much as anyone else. (It is a most consoling fact that there never was a fatal accident, to man at least, with the Limerick County Hounds.) A near neighbour of the coroner's, and a namesake, is John F. Sheehy, a frequent attendant at the meets, but, having much business to look after, he cannot attend the distant ones; a right good fellow, always well mounted and fairly placed. I believe I have exhausted my list, and as I am sure you have long ago, from the great length to which I have written, cried, 'Hold hard,' I will now close this communication with a few words of consolation to the very many promising aspirants for sporting fame who are regular attendants at the meets of the present day, but who may feel surprised, and perhaps annoyed, at not being alluded to in this communication; my intention (as mentioned already) is to devote to them my reminiscence No. 3 . After the death of Mr. Fosbery, the hounds were managed by a committee, of which Mr. Green was, I think, the head, and on which was the Rev. Thomas Croker, then residing on Croom 
Castle, on the ground connected with which the kennel stood, and, from its proximity to him, he was most attentive and liberal towards the whole establishment. He was generously aided by the Messrs. Stein of Limerick, one of whom was married to his daughter. Others also aided in the good work. After Mr. Croker ceased to reside at the castle the late lamented and highly popular Colonel Dickson became proprietor of it, and, I believe, sole manager of the hounds, and by his daily attendance at the kennel evinced the deep interest he took in it. After the retirement of poor lat Connell an English huntsman named Goodall was brought over, but he did not retain the position very long, as he did not give satisfaction; he was too fond of the use of whipcord, on account of which the hounds became somewhat unmanageable. This habit was acquired while acting for many years in the capacity of whip to an English pack, and which trait, though sometimes essential in a whip, should by no means be exercised too severely by a huntsman, as it destroys all chance of securing an obedient pack. A very nice English boy, named Alfred, acted as second whip during the time that Goodall was huntsman. These both were, I think, the protoges of Colonel Dickson. Jack Bourke, from the Duhallows, succeeded Goodall, and, I believe, retained the position up to the time that the hounds were transferred to Sir David Roche. Bill Cliquette was whip during Jack Bourke's time, and on change of master Jack returned to Duhallow, and Bill took service as coachman, his knowledge of the use of the whip being, I suppose, a recommendation for that position. One word as to coverts, and though not in the least disparaging the hunting of the present day, I am sure those who remember them will agree with me in saying that the runs from the celebrated, but now unused coverts of Bunmona, Fanleehane, and old Garryfine, far excelled those we now see. They were very seldom drawn blank, and the first burst in connection with a find at any was such as to require a stout horse and a bold heart to get througn. The runs from the first-named always ended at some place in the county Cork, a considerable distance from the boundary line which divides that county from Limerick, and from the other coverts nearly, though not quite as long. These coverts were in an open country, and not so near each other as some of the coverts now drawn. The impediments which now spoil many a run, namely, railways, and, in some cases, formidable water-courses, sunk in connection 
with main drainage, did not then exist, and for this reason there seldom occurred anything to prevent the continuance of the rattling pace at which both hounds and horses started when 'tally-ho' was shouted. As in my last communication, with a very culpable want of gallantry, I left to the latter end the introduction of the names of those fair ladies who by their splendid equestrian performances contributed so much to increase the attractions of the hunting-field, I almost fear to introduce now in this not altogether final portion of my reminiscences the present, but more numerous, contingent of the fair sex that then, as well as now, were able in many instances to put to the severest test the equestrian powers of the sterner sex. I will not presume to name any of them, but only say that a few of them who enjoy that happy state to which all the fair sex aspire clearly show that the heart is not less bold nor the spirit in the slightest degree trammelled by their matrimonial responsibilities. In my next I will introduce those candidates for hunting fame of the present day, all of whom, though in the incipient stages, exhibit all the indications of the possession of those qualities that constitute the elements of a good sportsman, for, though shelved myself, I am not so churlish as not to be delighted at seeing the rising generation enjoying that glorious sport that often gave myself such intense pleasure. My gratification at their enjoyment is not diminished by having a representative of my own amongst them.

"I am, dear Mr. Editor,

"One who was often with Them.

"March 6th, 1877 .

"P.S.-I find on looking over the lines I have written that I omitted some names that should not by any means be overlooked. I should have named next after the Hon. Hugh Massy, Mr. Robert Massy, now residing at Faha, near Elmpark, but during nearly all the time that he was connected with the hunt he lived at Greenmount with his relatives, Captain and Edward Green. Mr. Massy still attends the meets regularly, and is a good supporter of the hunt. In connection with the city I should have given you the names of Mr. George Horan, Captain Furnell, and Captain Westropp. I need say nothing of them, as they were all well-known to be most fearless, not only in the hunting-field but the two latter 
also even at cross-country work in the shape of steeplechasing. I must not forget one who deserves most credit of all for his fearless, and I would almost say, reckless riding, Vesey B. Isaac, then residing near Charleville, and who, though deprived of the use of one leg by amputation, and obliged to use as a substitute an artificial one, still, with the aid of a peculiarly constructed saddle and on his celebrateted horse Tonic, was always to be found amongst the foremost." 


\section{CHAPTER XIV.}

\section{HUNTING IN ROSCOMMON.}

Is there not a charm in antiquity? Old pictures, old china, and, particularly, old port, how they please us! The girl of "sweet seventeen" enchants; and old ladies-I beg pardon, women never grow old. The youthful athlete challenges our admiration, but we appreciate not the less those seniors whose seamed faces and locks, stained with the dust of the road of life, indicates old age. Respect age if you would command respect. Pardonnez-moi, reader, I must hark back to the subject of this chapter. Hunting in Roscommon county is of such ancient date that it set me thinking on antiquity, and caused me to regret that the old French-Park Pack was not kept up, as it was in existence more than a century ago, and maintained by the French family until I 859. The oldest record I have found of the French-Park Foxhounds is when they were presided over by Mr. John French, M.P. for Roscommon in 1743 : but hounds were kept in French-Park for years before that. Mr. John French hunted different parts of Ireland, according to arrangement, and used for many seasons take the hotel in Kilcock for a month, and hunt parts of Meath and Kildare. This gentleman was drowned, cruising from Dublin to Park-gate, in 1774. After his death the 
hounds were kept by his brother, Arthur French, and afterwards by his (Arthur's) son, Arthur, until his death, in 1820 , when he was succeeded in the mastership by another Arthur, son to the former, afterwards Lord De Freyne. He was an ardent sportsman, and improved the pack very much by importations from the best kennels in the kingdom. He hunted the entire county of Roscommon until his death, in 1856. Game was at that time very scarce, and bagged foxes were the rule not the exception. After his demise, the hounds were hunted by his brother John, second Lord De Freyne, who continued to do so until 1859 , when scarcity of game obliged him to discontinue fox-hunting. He, however, kept on some of the hounds, and hunted the stout hares on the plains of his native county until his departure for the happy grounds, in 1863. A few words about this valued Irish sportsman will not be inappropriate here.

Universal was the grief amongst the sport-loving community throughout Ireland when they heard that his Lordship had paid that debt which we must all one day discharge. They mourned in him the loss of one who had done much to promote the welfare of his countrymen; a nobleman who endeared himself to his peers and equals, and especially to the poor residents in his neighbourhood, for he was to them a benefactor in the truest and widest sense of the term.

Lord De Freyne, second son of Arthur French of French-Park, Castlerea, born in 1790, succeeded to the title, at the death of his brother, in 1856 . The love for field-sports is strongly inherent to the members of some families; and the Frenches have for generations been proverbial for their marked predilection for 
the turf and the chase. The subject of this brief notice was a clergyman of the then Established Church, and Rector of Sylvoe, county Kilkenny. He was always fond of horses and hounds, and from his boyhood kept race-horses, and, under the assumed name of Montgomery, ran several while he resided in Kilkenny. He was a true sportsman; loved racing for its own sake, and never bet a shilling. He had a passion for field-sports, ample means at his command to enable him to enjoy them, and, it may be said, that he steered his course honourably amongst the quicksands which surround those who pursue similar pleasures, and are, alas! too often tempted to lose that sense of honour so essential to true happiness. Lord De Freyne was "one in a thousand," and showed an example worthy of imitation. He did not visit many race-meetings until after he went to reside at French-Park, which he did in $\mathbf{1} 835$. He then increased his stud; and from that time he attended every important Irish meeting. In 1846 , it was thought that he had a promising candidate for Grand National honours in Clansman. But this good chaser nipped the hopes of his backers in the bud by falling early in the contest, and breaking his back. The great Aintree race was an unlucky one for his Lordship in more than one instance, for, in 1862 , his horse, O'Connell, fell, when running well for the Liverpool, and killed poor Joe Wynne, a fine horseman, and very popular jockey. Lord De Freyne did much to improve the breed of horses in Ireland, by importing good sires from England; and he never was without a large and wellselected lot of stud matrons of the best strain of equine blood. Amongst the many celebrities he had 
were, Ophelia, Olympia, O'Connell, Caustic, Cripple, and Vixen. He had about seventy horses at the time of his death; and they, as well as the hounds already alluded to, were sold soon afterwards by auction; several of the chasers for a very long price, and some of them proved remunerative to their new owners, especially Caustic and Farintosh. The first-named won the National Hunt Race at Punchestown, value $£ 5$ Io, carrying I ist. x Ilbs. in 1864 . He then belonged to the late Marquis of Clanricarde, and was ridden by the late Mr. Willie Long, who ranked this race as his greatest victory in the saddle.

The late Mr. James Balfe had, long ago, a pack of hounds, but the want of foxes compelled him to dispose of them. Previous to $186 \mathbf{1}$, Mr. Longworth hunted the southern portion of the county, near Athlone, and Mr. John Dennis the western part. The good sport shown by the latter induced the sportsmen of Roscommon to get up a county pack; and a committee was appointed, with Captain George Warburton Drought of Cargins, Tulsk, as secretary. Foxes| were procured, and several coverts sown. The prospect of affairs soon became so cheering that, in 1862 , Captain Drought was induced to take the mastership; and, having obtained drafts from the best kennels, he began his régime with a good pack. During the first season, I862-3, he had, as huntsman, Martin Quirk, who previously hunted the French-Park Hounds, and had spent some years in Meath and Kildare. The following season the master carried the horn himself, having as first-whip George Sheppard, who hunted the Wexford Hounds during the season $1876-7$, and had been for 
some years with the late Sir Tatton Sykes before he came to Roscommon; Hugh M'Keon, afterwards huntsman to Mr. John Longworth, was second-whip. This arrangement continued for five seasons, the sport being very good. Then, unfortunately, Captain Drought was obliged to go abroad for the winter on account of his health. He was an excellent M. F. H., and his brother sportsmen regarded with sincere admiration a master to whom they owed so much. Mr. Tom Bodkin of Kilclooney succeeded Captain Drought, and he, poor fellow, was soon afterwards killed in the hunting-field whilst hunting the hounds. The taste for pheasant preserving was then at its height, and Irish keepers not having the art of keeping foxes and pheasants in the same coverts, fox-hunting in Roscommon became a thing of the past. Stag-hunting is, however, better suited to a county where there are so few resident landed proprietors, which is very open, and where there is such an extent of bog. And those hounds afford a better opportunity for the many hard riders resident in the neighbourhood to show their skill and their hunters' cleverness, and to cool the daring spirits that were wont to chafe at the drawing of such large coverts as Mote-Park or Danamon.

In 1873, a pack of staghounds was formed, by Captain M. J. Balfe of South-Park, and he has hunted them himself ever since in a manner which does him infinite credit. There was, of course, much trouble experienced in getting together a good lot of hounds, but the difficulty was soon overcome. Having inspected them on the flags, and seen them perform in the field, I can vouch for 
their excellence in every particular. Captain Balfe laboured sedulously and successfully to gain the end he has so fully attained, and has now the pleasure of having in his kennel thirty-and-a-half couple of working hounds, including a very promising entry. They average twenty-five inches, and are remarkable for their pace, symmetry, uniformity in size and colour, steadiness, and endurance. With a subscription of $£ 700$ a year, the master of the Roscommon Staghounds has certainly achieved more than his most sanguine admirers could have expected, although much was, no doubt, expected from him, as he is descended from a family remarkable for their love of racing and hunting. His father and uncle were both staunch supporters of the Irish turf some years ago.

The kennels at South-Park are good, and so are the stables. Captain Balfe is a first-rate judge of horses, and always keeps fourteen or fifteen hunters of the right stamp. John Cooke was whip and kennel huntsman until the end of last season (1876-7). He has been succeeded by William Higgins. M. Harte is feeder, and an excellent canine physician; indeed, he would be an acquisition to any hunting establishment. He lived for many years with Mr. John Dennis, and subsequently with Mr. Tom Bodkin, at Kilclooney. After Mr. Bodkin's death, he came to South-Park, where he has been ever since. Many parts of the large district hunted over by these hounds is a good hunting one, particularly the neighbourhoods of Rathcrogan, Mullaghdowney, and the plains of Boyle. There are many liberal contributors to the hunt fund. Lord De Freyne heads the list with a donation of 6100 a year. The Frenches are "sportsmen to the 
manner born;" and the popular member for the county, Hon. Charles French, subscribes liberally; and so do his brothers, the Honbles. John and William French ; Lord Crofton, Lord Kingston, Captain KingHarman, Major Balfe, the O'Conor Don, M.P., Messrs. J. P. Taafe, Patrick Taafe, John C. Murphy, John Burke of Carraroe, Flanagan, C. Hawkes, C. A. Keogh of Oakport, T. Y. L. Kirkwood, E. Frazer, Glancy, Bagot, C. M'Dermott, A. Lawder, John Devenish, the brother's Sweeney, Lloyd, Cotton, R. Flynn, Mahon, and J. Stafford, all subscribe handsomely.

Since the establishment of the Dublin Horse Show, the Roscommon horses have become famous. They generally carry off several of the jumping prizes ; and there are more good hunters bred in that county than in any part of Ireland. There are so many noted straight-goers amongst the followers of the pack under notice that it is almost impossible for me to ascertain all who are deserving of being included in my list of first-flight men. I may omit some who are deserving of the distinction, and if so, I hope they will pardon an unintentional slight; and I feel sure that all will allow that Captain Balfe, the Hon. John French, T. Y. L. Kirkwood (a welter-weight), the brothers Sweeney (three), Messrs. Cotton, Farmer, Flanagan, Lawder, and R. Flynn, generally comprise the leading division. Mr. Charles Hawkes, wearing silk and scarlet, has earned a deserved reputation as being a fearless and accomplished rider. Mr. Burke of Carraroe-park, with only one arm, rides better than most men with two. Every sportsman must hail with pleasure the appearances of the fair sex in the hunting-field. They give tone and animation to every scene they deign to 
honour with their presence; and, but for their sanction, hunting would not be as popular or as enjoyable an amusement as it is. Many ladies hunt with the Roscommon Hounds; and some of them ride remarkably well: Mrs. Taafe of Foxborough, Mrs. Taafe of Cams, Miss Nolan of Beechwood, Miss Kirkwood, and Miss Chichester, often keep in front through a good run, and always ride with remarkable grace and skill.

Mr. C. A. Keogh of Oakport, gives place for all the deer in his fine park, and gives a couple of reddeer every year. Mr. Lloyd of Crogan gives two or three every season also, and Lord De Freyne four or five fallow deer.

When forming the pack, Captain Balfe got all his hounds from England, and several from Her Majesty's and the Craven kennels. 


\section{CHAPTER XV.}

THE SOUTH UNION, UNITED HUNT, AND MUSKERRY HOUNDS.

I SHALL condense the history of the South Union, Muskerry, and United Hunt, into one short chapter. I have to adhere carefully to the line of accuracy, having to deal with facts and shun fiction; so that as I do not know very much of the hunting territory of these packs, their supporters, followers, or of the hounds, I must be brief in dealing with them.

The South Union Hounds were established in 1830; they were Irish bred, and comprised drafts from the best kennels in the South, such as Mr. Hedges Eyre of Macroom Castle, Captain George Rye of Ryecourt, William Baldwin, and Mr. Stannus. They hunted both hares and foxes until 1866, and since then they have been regularly established as foxhounds. The present master's father was the first to preside over them, and he kept them till his death in 1840. During his long reign he had only two huntsmen, William Sullivan and Denis Hallis. Mr. T. Walton Knolles succeeded at the death of his father, and has presided since then. He resides at Oatlands, near Kinsale, and hunted the pack himself, until incapacitated from doing so by an injury 
to his knee, sustained by a fall on the road in $\mathbf{1 8 6 4}$. Since that time the present huntsman, Denis Mullane, who was formerly huntsman to Lord Doneraile, has carried the horn. Of late years, drafts were obtained from the Duhallow, United Hunt, and Lord Doneraile's kennels. The pack at present consists of twenty-one couple. Tuesdays and Fridays are the hunting-days. The sport last season (1876-7) was very good. The hounds were out fifty-three days; killed ten brace of foxes, ran to ground forty-four; there were ten unaccounted for; and three blank days. The huntingdistrict extends, by the sea-shore, from the Bandon river to Cork, and is bounded on the north side by the hills of Ballincollig. Scent lies badly in nearly all parts of it. It is much to be regretted that many foxes were poisoned last season in the neighbourhood of Cork; there are but few foxes in that locality now, and this is a great drawback, as the hunting-district is a very small one. Mr. Knolles is extremely fond of hunting. He is much liked; and during his thirtyseven years' reign as master of hounds, has discharged all the duties required of him in a manner deserving of high praise; and it is surprising how little support has been given him of late; but it is but justice to record the fact, that Mr. Marmaduke $\mathrm{C}$. Cramer of Rathmore, Kinsale, is a very liberal subscriber to the hunt fund.

During the late master's time, Messrs. John and William Galwey, William Markham, Thomas and William Bullen of Kinsale, generally comprised the leading division in every good run. The leaders of late years included the late James Galwey, Samuel Hodden, M. C. Cramer, Henry Burnett, John Meade 
of Ballintobber, William Newenham of Coolmore, Thomas Hayes, William Patton, and M. Donegan.

\section{THE UNITED HUNT.}

So many changes have taken place in the management of this hunt, that it is by no means easy to trace it through all its phases. It was originally established in the year 1824 or 1825 , by the late Mr. Simon Dring of Rockgrove, county Cork, and was then known as the "Union Hunt," and an Englishman, Paul Quirke, was huntsman. Mr. Dring was succeeded by Mr. Devonshire, and the hounds were then removed to Kilshannig, near Rathcormac. It appears that the sport was very poor during the régime of Mr. Dring; nor was all satisfactory under Mr. Devonshire's dynasty.

I take the following, written by "D. G.," from an English sporting magazine of 1837 :-

"I have been a good deal surprised that none of your Irish correspondents has ever tried to prove the superiority, in an Irish country, of the old Irish foxhound over the English blood. Though we have had the question fairly tried here, I shall not attempt to enter into their relative merits; but I will state a few facts, which may elicit the opinions of more experienced sportsmen and practised writers. About ten years ago the Union Hunt Club was got up to hunt an extensive country in the county of Cork. Two packs, one of mixed, the other of pure Irish blood, were presented by their owners (one of whom became manager) to the club, and a round sum was subscribed and paid up. The exclusive hunting of an extensive district was obtained. The club and the cub-hunting commenced with the most cheering prospects; but although our proceedings commenced so favourably the sport of the first year fell far short of our expectations. At the wind-up dinner the failure was admitted by all, but the opinions as to the causes which 
led to this result were various and widely different. The younkers, and they were the majority, held that nothing could be done except with a pack of pure English blood. The nestors of the chase talked of the good old times, and stuck out for the old blood; the juniors, however, were positive, and, being the majority, of course they carried their point, and the palaver ended with a resolution to import as many hounds of English blood as possible, and get rid of the Irish curs. The governor went over to Leicestershire with full powers and a full purse. Drafts were procured at a high figure from some crack kennels, the native Irish hounds were got rid of, the coverts stocked, Michaelmas day came about again, and our hopes were higher than ever. Anuther winter passed, and at our St. Patrick's Day feed we had once more to debate on a chapter of accidents, crosses and losses of all kinds, blank days, foxes no sooner found than lost, no pads on the kennel door, not a single long run to talk over, and a very long bill to pay, our exchequer running low, and our spirits lower. This year we determined that it was all the huntsman's fault, that the English hounds did not understand his Irish brogue-how could they? So we dismissed him, and imported a Meltonian. In the third and fourth years it was ditto repeated; in the fifth we transported our Englishman and imported a Scotchman: in short, to wind up the history of our 'Decline and Fall' in the ten years of our existence, we tried four huntsmen, as many managers, twice as many secretaries, whips innumerable, and had not a single run worthy of reporting in a sporting journal. The subscribers dropped off, the club became bankrupt, the horses were sold, the hounds were brought to the hammer, but no one would bid for them. We then puffed them off in all the papers for six months, and at length sold them for about a tenth of the first cost. Having shown the total failure of an experiment, thus fairly tried with some of the purest English blood, manned by Englishmen, and hunted à l'Anglaise in every sense of the word, let us take a peep at the other side of the picture: there we shall see what has been done this present season, in the same country, by a little pack of the 'ould Irish' blood, kept by an 'ould Irish' gentleman, who would as soon think of letting an English foxhound into his kennel as of allowing an English sportsman out of his house at seven o'clock on a hunting eve. His huntsman and whip, Jack Lynch and Dinny Shuckaroo, though they never crossed the Irish Channel in their lives, can 'discoorse' 
their hounds in as classical dog-language as if they had taken their degrees under Jack Musters himself, or matriculated in the Quorn kennel.

"When the much-admired, the beautiful, and dearly beloved English pack went to the 'dogs' the owner of the little Irish curs got the hunting of a great part of the country in which the defunct club had long played the part of the dog in the manger. $\mathrm{He}$ commenced the season with a pack short as to numbers, his effective strength being only twenty-eight couple. With this small force he took the field under the further drawback-owing to his having few coverts to draw-of having more frequently used them as harriers than foxhounds, though sometimes guilty of the solecism of finding his fox in a bag. However, a few thrashings made them as staunch as if they never stooped to the trail of a hare in their lives, and he has not had a single blank day as yet. I had the pleasure of hunting with him for a few days; and while I was anything but enjoying the otium entailed on me for my sins by a severe attack of the influenza I attempted the following sketch of a day's sport:-

"On my first appearance at the covert-side with this, the merriest pack I ever rode to, the meet was at Lemlara, the residence of the county member. The draw was blank, the morning wet and cold, and not a drop to cheer us. This unpromising state of affairs sent a lot of feather-bed sportsmen from the sweet city of Cork home to their clubs. The field, which was before rather numerous than select, was now reduced to about ten well-mounted men in scarlet, that looked as if they could 'ride a bit.' Our next draw was Dundullerick glens, and while the hounds were going down we got a caulker of real cherry-bounce, which the rawness of the morning made most acceptable. The little ones were not long in the covert-a beautifully planted, deep, and rocky glen-when they opened on a drag in a style that left no doubt as to our finding. The cry in the glen was the finest I ever heard, and was sent back to us by a hundred echoes. But this did not last long, for our fox broke away in gallant style, like a prime one that despised dodging, heading due north, the wind at the time blowing a cold southeaster. He had scarcely a minute's law when every hound in the pack was out of covert, all settling to their work, heads up and sterns down. As this (if you please, Mr. Editor, to print it) will meet the eyes of many who know the country well, I shall give the 
names, unpronounceable though they be to your English readers, of the several townlands over which the varmint led us. After leaving the demesnes of Dundullerick he crossed the fine grass farm of Rathgubbane, to his own great disadvantage, as the 'doggies' settled to their work where there could be no mistake. He then held on through Ballyroberts, Rathanigue, Ballinvullin, Ballynakilla, then across to Kippane, up through Bluebell and Lisurrilla, a long and steep hill, which tried the metal of the nags-some of them not unknown to fame. The fox then descended in a straight line through Ballynandagh and the old Barrymore Park, to the river Bride, where two or three of our select few treated themselves to a cold bath, mistaking one of the deepest reaches on the river for a safe and easy ford, which was close by. When safe across the flooded stream, poor pug was nearly at home, for a quarter of a mile carried him to the rock of Castle Lyons, ' an asylum where foxes for many a gineration have found refuge from their rival persecuthers,' to use the words of an Irish schoolmaster, who ran out, followed by all his pupils, to see the finish. The said learned person at the same time informed us that one of his 'Latinists'a bit of 'nate timber' to make a scholar of-ran in and thus addressed him in choice Virgilian phrase:-Domine, hic venizut equites et odora canum vis,' which he, the said Domine, as he told us, thus rendered into the vernacular for the benefit of the "lower class :'-'Boys, here come the red-coats and the hounds!-adding to his translation the pleasing note, 'Take a quarther holiday!' We arrived just in time to see wily reynard take 'refuge from his rival persecuthers' in one of the caverns under the rock. The pedant's phrase, 'rival persecuthers,' was, to quote another brother of the ferule, 'a most liable, congruent, and measurable application of the epithet.' I never saw such racing before-from find to finish-the thing was done in a most workmanlike form. There was scarcely a check for a second, and not a cast was made. The line taken was as straight as man and horse could go. The distance, seven miles (Irish) from point to point; time, twenty-eight minutes. Now for a word about the cavalry. In so decisive an affair as this there was a fair opportunity of seeing who was the best mounted man, but it would be hard to say which of two bore away the palm. The par nobile were Mr. Fitzgerald on Valentine, the hero of many a well-contested steeplechase; and Mr. John Barry on Psyche, a small but prime bit of stuff. She won the third 
and fourth heats of the best-contested steeplechase that ever came off in Fermoy, beating Red Rover, the conqueror of Barkiston and Conrad, since sold to the Marquis of Waterford for 300 guineas. Next to these, if not in with them, should be placed Mr. Wakeham on Cigar, the winner of the Muskerry Cup. About a field behind came Mr. Morris of Dunkettle, on Clinker; Mr. Roche, the owner of the hounds, on Champion, a 200-guinea article; and the huntsman on a Whiteboy mare. Dinny, the whip, dived into a bog-hole about the fourth mile, and never took his place again until all was over. The innate modesty of an Irishman prevents my placing myself; suffice it to say that I don't quote the knight of the birch at second-hand. Mr. H. Barry and three or four others formed the rear-guard, and arrived just as we had finished a fierce attack on a venison pasty and sundry other good things at Mr. Fitzgerald's, in Castle Lyons, and as we were about to 'fight our foxhunt over again.' They told us the usual pitiful tale of broken stirrup-leathers, lost shoes, \&c., which were received, as such stories always are, with a horse-laugh."

Soon after the publication of this article $\mathrm{Mr}$. Roche's hounds were dispersed. In I 840, Mr. Devonshire sold his pack to the late Lord Shannon; and they were hunted for a few seasons by a man named Brown. In 1845 , Tom Smith, from the Brocklesby, succeeded to the horn, and he was quite au fait at the business, and he had valuable aids in the brothers Atkinson, who were whippers-in to him. In 1847 , his Lordship disposed of his hounds to Lord Southampton, and Smith went with them. That famous sportsman, Mr. John Courtenay of Ballyedmond kept a pack of hounds for some years, and showed very good sport, over what is now the United Hunt district. Mr. Courtenay (whilom Steward of the Turf Club) owned several good racers and chasers. In 1847 , he won the Liverpool Grand National with Matthew, which, under the careful guidance of Denny Wynne, defeated twenty- 
seven opponents for the cross-country blue-ribbon. $\mathrm{He}$ also owned Caprice, a dark-grey mare (dam of Frailty), a wonder over four miles. She won many races under "Eddy" Keegan, who believed her to be the best animal he ever bestrode. Mr. Courtenay was a notable man to hounds, and rivalled his friend Lord Henry in those feats of horsemanship which have made the name of Waterford imperishable. When an old man, in 1858 , Mr. Courtenay capped his former performances by riding his hunter, Blenheim, over the dining-table "set-out" for supper in the Club House, Kilkenny. He sold his hounds to Sir Nugent Humble in 1848 .

The country was not then hunted until 1855 , when Mr. Robert Uniacke of Castletown, near Killeagh, bought Sir Nugent Humble's pack, and hunted this entire district, as well as a portion of Waterford, which had been previously hunted by the Black Water Vale Hounds, and were sold in 1847. Mr. Uniacke carried the horn for two seasons, with John Smith as first, and Wm. Keeffe as second whip. He then gave up the Waterford country, and took a large tract of that formerly hunted by the late Lord Shannon, and the pack were known by the old name of the "Union Hounds." John Snith was huntsman for a couple of years, then Patrick Neil, who was entered by Mr. Uniacke as second whip, was promoted to the office; he failed as a huntsman, however, and became first whip under James Alexander. In 1870, Lord Shannon bought Mr. Uniacke and the late Lord Fermoy's hounds, and the two countries (for L.ord Fermoy hunted half the Union country from the time the late Lord Shannon died till 1870). 
Lord Shannon is now one of the most popular masters in England, where he has the Vale of White Horse Hounds.

Henry Robert Boyle, fifth earl, was born in 1833 , and was educated at Eton. When nineteen years of age he went as attaché at Frankfort, whence he was soon afterwards transferred to Vienna. In 1853 , he retired from the service, and six years afterwards married Lady Blanche Lascelles, daughter of the Earl of Harewood. She died in 1863 , his Lordship succeeded his father in $\mathbf{1} 868$, and the same year married Julia Charlotte, youngest daughter of Sir William Cradock Hartopp, Bart. When his Lordship took the mastership of the United Hunt, he at once set about improving the pack and the country; indeed, he remade the country which had been hunted by his father. He had R. Pattle as huntsman for one year, with Pat Neil, who had been whip to Mr. Uniacke. As first whip, Pattle was replaced by Wheatley, previously whip to the Duke of Grafton, and his "aids" were P. Neil and John Curtis. After a lapse of two years, George Bollin was made huntsman, with Tom Perry and Curtis to turn them to him. In $\mathbf{1} 875$, Lord Shannon gave up the hounds, and sold his bitch pack to the present committee of the United Hunt Club, and his dog pack to the Duhallow Club. The managers of the United Hunt soon succeeded in getting a good dog pack, and they have now forty-five couple of working hounds. The hounds were kept at Castle-Martyr; but were removed very recently to new kennels at Middleton, a nnove in the right direction certainly, as they are five miles nearer to the centre of the country. Last season (1876-7) John 
Mason was huntsman, with J. Wallis as whip. Henry Saunders, who was for some time first whip to the Louth Hounds, carries the horn now, and Wallis remains as first whip. They hunt three days a week. Mr. Uniacke is kennel manager. He is a most ardent foxhunter, and is thoroughly versed in stud lore. Mr. Thomas IV. Gubbins of Dunkettle, county Cork, is field manager, and a most courteous one; he is a great favourite, and thorough sportsman.

THE MUSKERRY FOXHOUNDS.

IN 1780 , the Muskerry country was hunted by $\mathrm{Mr}$. Richard Tonson Rye of Ryecourt (grandfather of the owner of the present pack, Captain R. Tonson Rye); John Donohue was his huntsman. In I 800 , they were kept at the Ovens by Mr. Ballie Collier, Mr. Samuel Hawkes of Hawkemount, and Mr. James Penrose of Shandangan, and were hunted by Tom Geary, who afterwards went to Lord Carbery. After hunting the country for six years, they were joined by Captain Hedges of Macroom Castle, until I8 I 5 , when the latter took the hounds himself, and hunted the country entirely at his own expense until his death in 1838 . The hounds were then left to the present Earl of Bantry, who lent them to the late Samuel D. Penrose of Farren, the late John Hawkes of Kilcrea, and Mr. Richard Tonson Rye, who jointly hunted the country for one season; and then they were made a subscription pack, thereby gaining a large addition of country, viz., that hunted by the late Mr. Newenham of Maryborough, and the Innishannon country, hunted by the late Captain Corcor of Cor Castle. The late John Hawkes of 
Kilcrea then became master, and, with Denis Sullivan, huntsman, and Patrick Connell, whip, hunted the country successfully until 1843 , when the Earl of Bantry sold the hounds to Mr. Drought of Roscommon. Then Captain R. Tonson Rye got a pack of foxhounds, and has hunted the country ever since with great success. Captain Woodley, who is a first-rate horseman, carries the horn. At the beginning of the present season (1877-8) Captain Rye gave up the mastership, but lent the hounds to hunt the country. Captain Woodley is now master. Tuesdays and Fridays are the hunting days. The kennels are new, and situated near Meyshell; James Kerlihy is firstwhip and kennel huntsman. The pack generally consists cf thirty-two couple of working hounds.

\section{NOTES.}

A notice of the sportsmen of Cork would be incomplete did it not make some reference to a very extraordinary man who occupied amongst them a position quite unique-I allude to the late Mr. "Philip" Cross of "Shandy Hall." He died lately, and full of years, during which he shot, fished, and hunted with a spirit which could only be borne by a quite extraordinary constitution. Space only permits me to record one of his many exploits. Before he disposed of his latest pack to an English gentleman (the sale of which was the subject of a very remarkable lawsuit which Mr. Cross won), and when a very old man, he shot four couple of snipe for a sick friend, to whose home, some nine miles away, he bore the birds, and met his horse and pack at eleven o'clock, a.m. He hunted, and killed a hare, then ran into an outlying fox in "the open;" came home, and killed a very fine salmon in the Macroom river before the sunset of a late March day. Many of my readers will, no doubt, recall the vigorous old man in the light frock coat and white "duck" trousers, which, when not hunting, he thought quite sufficient protection in even the most inclement weather. His was an example of hardihood always rare, and, perhaps, in these faster latter days impossible to be met with. 
Another very remarkable southern sportsman died a few years ago, old "Dan" Callaghan, the veteran huntsman. He was born, in 1763, at Ballyclough, near Nallow. When fourteen, he went into service, and was kennel-boy to Lord Lisle for two years, and whip for four years, and was then appointed huntsman to Lord Lisle's nephew, Mr. Lysaght. He hunted his hounds for seven years, and then carried the horn for eight years for Mr. Hugh Norcott, who kept hounds at his residence, Ballybeg, near Cahirmee. His next master was Mr. Hedges Eyre of Macroom Castle, whose hounds he hunted for nine seasons, before he entered the service of Mr. Power of Clonmult, whose pack he hunted for thirty-seven seasons. He filled a similar post for a few years to Mr. Boles of Springfield, and for fifteen years he lived with his last master at Shanagarry. Poor Dan! he was a first-rate horseman, and won several steeplechases. There was no better man to hounds, but a very jealous rider. He was ninety-nine years old when he gave up service. He died in 1874 ; and in 1868 , her Majesty the Queen was graciously pleased to accept his photograph, and presented him with a gratuity of $£ 5$. 


\section{CHAPTER XVI.}

THE ORMOND AND KING'S COUNTY HOUNDS.

HAVING left the "kingdom of Connaught," I continued my tour in quest of information for these hunting sketches, and, on the borders of Tipperary, I found a Mentor, willing and able to afford me much information relative to the Ormond Hounds and country.

"Now," says mine host, "having catered to your wants as regards the 'inner man,' we will have a chat about your book and a smoke. If there is any truth in the proverb, 'in vino veritas,' it is not badly capped by 'ex fumo dare lucem;' we get the silver lining of the clouds, we say our best things, and keep the real conversation of the day for that cheerful hour when ordinary mortals have retired to rest. I will tell you all I know about our hounds. You do not surprise me when you tell me that you have had more difficulty in obtaining details regarding the Ormond and King's County Hunt and the Duhallows than any other. They are, I think, established longer than any pack in Ireland; and so many changes have taken place in the management of the 'Ormonds,' that it is most difficult to trace their history. You know there has existed an 'Ormond Hunt' and a 'King's County 
Hunt' at the same time, and at others the two countries have been hunted as one."

"So I have heard; how far back can you trace the history of the "Ormonds?",

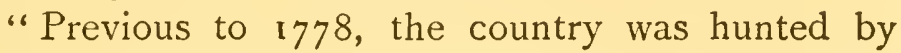
private packs of the local gentry, viz., the Tolers of Beechwood, the Falkiners of Mount-Falcon, and the Willingtons of Rapla. In 1778-9, the 'Ormonds' were kept by the late Viscount Lismore at Debsborough, near Nenagh."

"I heard from my Galway friend that the hounds kept by the late Colonel Giles Eyre used to hunt a portion of this country and part of Galway."

"Yes; he kept hounds, and hunted the country for many years previous to 1810 ; and so did Hero Jackson of Mount Pleasant. A neighbour of mine gave me the following account of a run which took place in 1809 . He found it amongst some old papers of his, but he does not know who the writer was :-

\section{"Extraordinary Foxhunt in Lower Ormond in 1809.}

"On the $4^{\text {th }}$ of December last, Colonel Eyre's foxhounds had one of the most desperate runs ever recorded, of one hour and fifty minutes-desperate from its length, desperate from 'the pace' kept up, and desperate from the dreadful storm that raged for nearly the last hour, and in the very teeth of which reynard ran. With the exception of short check, the chase was maintained with unabating fury all through, to choose a leap was to be thrown out. At half-past eighto'clock in the morning they drew over the old earth of Coolagoran for the 'spotted fox.' Tony, the huntsman, knowing well his abilities from former runs, matched his chase hounds the day before, and fed them early. He calls this pack the 'Light Infantry,' to distinguish them from the slack, heavy draft that were lately sent from England. I was on the earth a little after eight; it was rising ground, and as the dawn broke 'twas cheering to 
behold the foxhounds, faithful to their horn, approaching from distant directions, and as they all closed to the point of destination, the pack, 'in all its beanty's pride,' appeared on the brow of the hill :-

" 'Oh! what a charming scene,

When all around was gay, men, horses, dogs,

And in each cheerful countenance was seen

Fresh blooming health, and never-fading joy.'

"The taking his drag from the earth was brilliant beyond common fortune; like a train which runs off in a blaze, they hardly touched it till they were out of sight. 'Madman,' that unerring finder, proclaimed the joyful tidings; each foxhound gave credit to the welcome information, and they went away in a crash. It was a perfect tumult in Mr. Newstead's garden; there the villain was found, and we went off at his brush. In skirting a small covert in the first mile, we divided on a fresh fox; it was a moment of importance, nothing but prompt, vigorous, and general exertions could repair the misfortune; it was decisive, and he now faced the Commons of Carney, broad and deep was the bounds drain; but what can stop foxhunters? The line had been maintained by five couple of hounds; they crossed the road, and finding themselves on the extensive sod of the Commons, they began to go 'the pace.' A scene now presented itself, which none but foxhunters could appreciate, for its beauty was not discernible to the common and inexperienced eye. At this period, the chase became a complete 'split,' the hounds, which had changed, and had now, from different directions, gained the Commons, could not venture to run in on the five couple without decidedly losing ground, and, to maintain it, instinct directed them to run on credit, and, flanking the five couple, the whole pack formed a chain of upwards of 100 yards in breast across the Commons; but as the chase varied through the hollows and windings of this beautiful surface, the hounds, on the wings, in turns, took up the line, and maintained their stations, as the others had done, so well was this pack matched. Here we crossed walls that on common occasions would have been serious obstacles. The second huntsman, on a young one, following Lord Rossmore, called out: 'What is on the other side, my Lord?' 'I am, thank God,' was the answer. We now disappeared from the Commons of Carney, and at this time the pack was hunting so greedily that one would think every dog was hitting like an arrow. We now passed Carrigagown for the 
ponds of Peterfield, in the teeth of the most desperate storm I ever witnessed of rain, hail, and wind. Distress was now evident in the field, for notwithstanding the violence of the gale, 'the pace' was maintained. This was the most desperate part of the chase, and as the foxhounds approached the covert, I thought they had got wings; the rain beat so violently, with difficulty we could hold our bridles, the boughs gave way to the -storm, the 'Light Infantry' were flying at him, and the crash was dreadful. The earths at Peterfield were open, but reynard scorned the advantage, and gallantly broke amain. He now made for the river Shannon; some object changed his direction, and away with him to Claprior. $\mathrm{He}$ crossed the great drain of the Lough, and here we left young Burton Persse sticking, who had come 'all the way from Galway,' to enjoy a regular cold bath. He went down, tail foremost, and 'no blame to him ;' there was no time for ceremony, but Tony, who knew the depth of the ditch, took his leave of him, roaring out_- I'll never see your sweet face again!' 'By George!' says the Colonel, 'you never were more mistaken. I never saw him more at home in my life. He's used to these things;' and truth requires me to state that he joined us again, and before and after the bath he held a capital place; and many a mile he went by the old castle of Ardcroney, famous in the annals of hunting, and all over its beautiful grounds, and over the great bounds drain, into Coolagoran again, for poor reynard had now cast a forlorn look towards home at last. There was a disposition to give him life, but what could we do? 'Old Winner' was at his brush; Her Majesty's Guards could not have saved him. Thus ended a chase, during which we traversed about twenty-five miles Irish (making thirty-two English) of the finest portion of Lower Ormond. In running, Messrs. Fitzgibbon and Henry Westenra took a most sporting leap; a gentleman of the jockey type, who rode well through the chase, wishing, no doubt, to show us the length of his neck, craned at it, and swore that it was the ugliest place in Europe, and that a flock of sheep could be easily hid in it. There was a very numerous field at finding; but during this most desperate chase, George Jackson rode, as usual, with the hounds, as did also Lord Rossmore, Colonel Eyre, Messrs. Fitzgibbon, Henry Westenra, Richard Falkiner, and Burton Persse, all through."

"By Jove! what a run; but twenty-five miles at 
the pace hounds generally go now would be too much of a good thing."

"Oh, decidedly so."

"Who had the hounds after 1810 ?"

"The late Viscount Lismore again hunted the country, and kept his hounds at Peterfield. The Hon. George O'Callaghan kept hounds at Knocknacreewood House, and hunted the country for several years, having for his huntsman the celebrated Tony Cashen."

"He was a first-class rider and huntsman, I believe."

"He was-no better. He was whip to the 'Blazers' before he came to Ormond, and graduated under the famous Sam Smith, who was hunt-servant to the Persse family for many years, and a noted huntsman."

"Well, who was the next master?"

"Captain John Hammersly, who kept his hounds, as a subscription pack, at Northlands, near Cloughjordan, which is about the centre of the Ormond hunting-district. He had a very good pack of fine, big, symmetrical-looking, brindled hounds that were bred mostly from the kennel of Mr. Hedges Eyre of Macroom Castle; and he got some drafts from the Duke of Rutland."

"You say this pack was kept by subscriptionwho were the most liberal subscribers?"

"Lords Clanricarde, Lismore, Dunally, Bloomfield, Clonbrock, Messrs. Thomas Ryder Pepper of Laughton, and Otway Cave, were subscribers of $£ 50$ a year each; and there were over forty members of the hunt who dined together at Brindley's hotel, Nenagh, twice every winter." 
"Mr. Ryder Pepper was killed out hunting?"

"Yes; poor fellow!. On Captain Hammersley's death, the Ormond Hounds were kept by William Smith of Northlands, under a committee of George Jackson, Richard Falkiner, and Richard Bayley. Afterwards George Minchin of Busherstown kept them for four years. Then the Hon. Colonel Westenra kept the hounds at Sharavogue for about seven years, ending $1837 . "$

"The hunt was known as the 'Ormond and King's County Hunt' then?"

"Yes; Colonel Westenra was father-in-law to the present Earl of Huntington, and was one of the greatest supporters of the Irish turf."

"He was; I know he commenced to hunt the country in 1830 , at least there's a verse of an old hunting song that says so."

"I remember it. During the years 1838-9, Captain Launcelot Bayley, 68th Regiment, kept them, hunting Upper Ormond only; Eyre Baldwin of Bellepark hunting Lower Ormond."

"Who were the best horsemen in your country about this time, can you tell me?"

" $U_{p}$ to 1839 , amongst the best sportsmen and horsemen in the Ormond country were, George Smith of Gurteen, who was celebrated as a steeplechase rider, George Jackson of Mount Pleasant, Thomas Brereton of Raththurles, Richard Falkiner (4th Dragoon Guards) of Mount-Falcon, Alexander Carew of Killcarron, John Brereton of Oldcourt, Sir Thomas Dancer, Bart., of Modoneey, Richard. Bayley of Ballinaclough, Cooper Crawford of Rapla, Caleb Going of Traverston, John Falkiner of Willsboro', John Tuthill of Riverview, 
Thomas Hackett of Riverview, Thomas Spunner of Clyduff (both these gentlemen died about ten or twelve years ago), Henry Allen of Shanbally, Joseph Falkiner, of Rodeen, Captain Tom Middleton of Elm-hill, William Kennedy of Bantiss, and, some years later, Thomas Hemsworth of Abbeyville, and Thomas Smith of Silver-hill. In 18 , 9, Thornas Stoney of Kyle-park, near Borrisokane, kept the Ormond Hounds, and continued to do so for four or five years."

"Who was his huntsman?"

" Denis Coughlan."

"Who succeeded Mr. Stoney?"

"A sportsman of whom you have often heard, Mr. James Drought of Banagher. Yes, he was the best of sportsmen and most genial of friends. Richard Conroy was his huntsman, with Tom Mara, as first whip, whose voice it was a treat to hear, when those fine hounds would answer as if by magic with a crash."

"Mr. Drought was a supporter of steeplechasing as well as of the sister-sport, fox-hunting, I think."

"He was; with the Cob, Smerger, Mountjoy, and other chasers, to wit, the celebrated Dan O'Connell, with Charley Canavan (father of the present fine horsemen, David and Willie), made the extraordinary fly of thirty-two feet over the down fence at Lismacrorry, while racing for the cup, which Mr. Drought won two previous years, with the renowned chaser 'The Cob,' ridden by the greatest horseman of the day, Mr. Kelly, and by whom, though then supposed to be a second string, this much-coveted prize was won for the third and final win, when O'Connell broke down."

"Mr. Drought resigned in $\mathrm{I} 849, \mathrm{I}$ think?" 
"He did. In I 850, IVills Gason (now Colonel) of Kilteelagh kept the hounds at Richmond, near Nenagh, for three seasons, hunting Ormond, and IVilliam Ralph liunted them; he was formerly huntsman to Mr. J. Minnitt of Annabeg. Mr. Alexander Disney kept the Ormond Hounds at Bellgrove for two seasons, and Giles Morgan was his huntsman. The Hon. Fred Yelverton kept the Ormond Hounds for two seasons at Belleisle; a man named Dan Grennan hunted them during that period. Captain Saunders had a first-class pack for several seasons, and hunted the Ormond country."

"Where did he keep them?"

"At Ballinderry-park; and, after him, Toler Wolfe had them for two seasons, 1804-5, at South Hill, near Nenagh."

"Who succeeded him?"

"Fitzwilliam Walshe, who also hunted the country for two seasons; his kennels were at Ballinaclough, and Dennis carried the horn. Mr. Walshe, at his own expense, purchased some very valuable hounds, which he added to the pack; when he resigned, in 1867 , he presented them to the hunt. Captain George Stoney of Kyle-park took them for three seasons, and Thomas Ryan (father of Tom Ryan, the steeplechase jockey) hunted them. Then Mr. George Jackson of Rapla kept them for two years; he carried the horn himself, and Mr. Wallis was first whip. In 1872 , Lord Hastings (now Earl of Huntington) reunited Ormond and King's County, once more revived the préstige of the old Ormond and King's County Hunt, and hunted both districts with great success up to 1876 , when he re. signed the Ormond country, presenting that hunt with twenty-one couple of hounds." 
"Who is now master of the Ormonds?"

"Mr. W. Trench of Congort-park, Roscrea; a good sportsman; he hunts the pack himself; J. Smyth is first whip and kennel huntsman, and T. Smyth second whip. There are about twenty-one couple of hounds at present in the kennels, at Ballingarry, Shinrone. Lord Huntington keeps the King's County Hounds at his own place, Sharavogue, Roscrea, and has twentyfive-and-a-half couple of hounds. Tuesdays and Fridays are his hunting-days. The 'Ormonds' hunt on Wednesdays and Saturdays. As huntsman and master, Lord Huntington has acquitted himself in a manner worthy of commendation. He turns out his servants and hounds in A I style, is a good man across country, and possesses all the best qualities of an Irish sportsman. Mr. Assheton Biddulph of Rathrobbin, King's County, is first whip; an enthusiastic sportsman, fine rider, remarkable for his bonhomie, and a universal favourite; he, in many points of character, resembles what his father was, when he, some fourteen years ago, and for many seasons previous, kept an excellent pack of harriers. The late Mr. Biddulph was an old and staunch patron of the turf, and had many very good race horses. John Fitzgerald is first whip and kennel huntsman. I may tell you the Ormond Hunt Races were formerly held at Gren. nanstown, Ballygibbin, Lismacrorry, and later at Norwood, near Nenagh, and Kylenagoona, near Borrisokane."

"Now, will you kindly tell me something about the hunting-country?"

"The Ormond hunting country (North Tipperary) extends from the River Brosna, the county bounds 
near Birr, southward to Kilboy, near the silver mines at the foot of Keeper Range, a distance of about twenty-five miles, and from Lough Derg to Longford Wood, on the Templemore road, about fifteen or sixmiles from west to east.

"The country is particularly adapted to fox-hunting, being generally a high-lying limestone district, rideable at most seasons, and well studded with coverts, both gorse and woodland, at convenient distances from each other. The country is, generally speaking, a close one, and the fences are so various that a good hunter from Ormond will go well over any other country either in Ireland or England.

"The principal covers are Killeen Wood, Walsh Park, Derrybreen, Knockshegowna, Ballincor, Quakerstown, Congort, Sopwell, Knockmacree Wood, Mount. Falcon, Borriswood, Ballyquirk, Slevoir, Kyleanoe Wood, Kilgarvan, Nannie Moran's Rock, Annagh, Castletown, Johnstown Park, Peterfield, Knigh Hill, Ashley Park, Derrinasling, Corlderry, Ballycapple, Ballygibbon, Rapla, Norwood, Debsborough, Kilcoleman, Kylerue, Laughton, Inane, and Longford Wood." 


\section{CHAPTER XVII.}

THE QUEEN'S COUNTY HOUNDS.

MORE than a century has elapsed since the melodious notes of the foxhounds were first heard in the Queen's County:

"Many seasons past was often heard at morn The dear sweet notes of huntsman's cheery horn, And sweeter still the grand melodious sound Of deep-toned music from the eager hound."

About 130 years ago, Colonel Pigott of Capard kept a pack of deep-mouthed southern hounds, and about the same period, Colonel Barrington (Sir Jonah's grandfather) had a pack at Cullenagh, some of the blood of which was to be found in the Emo kennels when that pack was hunted by a very remarkable character, "ould" Paddy Forde, who died not many years since,

"When his reverend locks in comely curls did wave, And on his aged temples grew the blossoms of the grave,"

for he lived for nearly a hundred years. Poor "Paddy," he was an original of the purest watereccentric amongst the eccentrics. He could never see any person smoking at the covert side without manifest indignation. "Shure thim cigars spilt the scent 
in covert." Nevertheless, he had a happy knack of lighting his own "dhudeen" even when the hounds were running, and whenever they were carrying a good head he might be seen, apparently as happy as a prince, puffing away.

The hounds were once running in the lower end of the country, not far from Rosenalis, when, mirabile dictu, Paddy Forde was pursued by a bull from a haggard into a paddock, out of which there was no exit, except at an almost impracticable stile. He hardened his heart, and shaking his feet out of the irons, as was his habit when going at a "yawner," he got over safe, but it was into a plough, and the horse landing into the headland broke both fore-legs. Pat escaped uninjured, and his first exclamation was, when he turned round and saw his enemy the bull on top of the fence, "bad luck to ye, you baste, you bruck mee little pipe." More than a century ago, Lord Roden kept a pack and hunted a portion of the country, continuing to do so for some years, although he had but few followers in the field. And many years ago, Colonel Archdale, a noted sportsman, and native of Fermanagh, used to bring a pack from the North, and hunt part of the Queen's County, for a few months every season. He had a very nice residence near Emo Park.

When the Emo Hounds were established, Lord Portarlington, of Waterloo notoriety, resided at Emo; he was an excellent sportsman, and Sir Henry Parnell, the ardent advocate of Catholic claims, and first Lord Congleton, was master. He was a most popular man, and represented the county before the period of Catholic Emancipation. At the same time, Sir Robert Staples hunted what is now called the Ossory country, 
and Mr. Stubber, of Ballinahie, a Protestant clergyman, had a pack, and hunted deer, foxes, and hares. He was passionately fond of the chase, and scarcely a day elapsed without the "sporting parson," as he was aptly designated, having a spin with the "beauties." He had a very large fortune, and lived many years to enjoy it and the glorious pastime he loved so well. A good story is told of him which I cannot refrain from giving. He was confined to his room a considerable time before his death, and nothing pleased him more than to hear the cry of his hounds, and as the kennel was situated close to his residence he frequently enjoyed the treat. On the day of his demise he ordered his huntsman to bring the hounds to the hall door, and to turn down a hare. The pack having been laid on, "tackled to work with a will," and, giving great tongue, set out in hot pursuit; Mr. Stubber was delighted, and turning round in his bed, said to those around him: "Oh! is not that heavenly music." Mr. Stubber was not the only clergyman who kept a pack of hounds in the country, as Parson Smithson hunted foxes and deer with his own hounds some seventy years ago. Odd as it may read, it is true, that this Reverend sports.nan was for years stone blind, yet he hunted almost every day, and rode remarkably well across country; his servant was always in immediate attendance, and used to inform him what sort the fences were which stopped the way. Mr. Smithson had perfect hands, and was, of course, always well mounted on an old trained hunter.

His hounds were A I ; he loved their music, and bred for melody, and would immediately draft one that hunted mute. "Don't hear Rattler to-day; 
Rallywood silent, too. We'll draft them, Flood, we'll draft them," he used to say to his most intimate friend, Colonel Flood of Badger Hill-a "four-bottle man," who once fuddled the bishop on visitation, and wore his wig next morning, drawing, as was then the custom, on their fox.

A story told of Flood is worth relating, en passant. A friend of his-and none of them were teetotallers had a very admirable butler. In those days the habits of their masters and the convivialities of the diningroom were naturally imitated in the servants' hall, and what magnums of claret effected up-stairs, whiskeypunch did below, but "Billy" Guilfoyle was ever equal to the task of getting his master and his guests to bed. The Colonel was nightly in a condition to require his services, and continued persuasion on his part and the offer of very munificent wages to the servant at length induced Guilfoyle's master to permit him to exchange his service for that of the Colonel, on the hitherto prevalent honourable conditions that master and man should not be drunk together. There was, however, a probationary month stipulated upon by the high-contracting parties, which passed to the entire satisfaction of the hard-going owner of Badger Hill.

Then occurred the following scene: The time is breakfast, the Colonel seated. The Major-Domo has supplied him with the reviver of that period-a "can of flip" - and the dialogue opens thus :-

Guil._." I'm sorry to go, Colonel, but the month's up. I must go."

Col._" Go, d-n it, go! Why, Guilfoyle? why go? Is not everything as you wish it below? You can go. Do as you like, you know. But, d-n it, 
Guilfoyle, go. Oh no! you can't go. Do as you like, but don't go."

To which replies servant_- "Oh, I'll go, your honour. Honour bright, your honour-honour bright. I must go-honour bright,"

The Col._-"Honour bright-honour bright! What the devil do you mean, man? You can go or stay; but, honour bright! D - n it! you can't go. Honour bright."

Guil._-"Just so, your honour. You know we war not to be both drunk together. I kept the bargain. But, bloody wars! your honour, sir, I'm here thirtyone days now, and ye never gave me the chance. $O h$, honour bright, I'll go."

After Sir Henry Parnell ceased to act as master of the Emo Hounds, they were taken by Sir Walter Burrowes, and were then one of the best packs in Ireland, and well supported, hunting a very large district, including part of Westmeath and King's CountyCooper Hill, now belonging to the Carlow country was one of their best coverts. The "field" averaged from sixty to a hundred men, and it is no exaggeration to say that there were at that time more foxes in one or two demesnes than are now to be found in the whole country.

The change is easily accounted for: trapping was not then known; pheasants were not so much as thought of. The case is very different now, hence the greater scarcity of the fox family.

Sir Walter Burrowes, sad to say, died in the hunting field from a fit of apoplexy; the melancholy occurrence took place at Sheffield, near Maryboro', and hunting was stopped for some time in consequence. 
Then Mr. Thomas B. Kelly of Kellyville succeeded Sir IValter, but the poor fellow did not live long to enjoy the position he so worthily filled. "King Death" claimed him for his own when in the very prime of manhood; he was a most popular gentleman, a true sportsman, and a brilliant horseman, to hounds and between the flags. Mr. Sidney Cosby, father of the present owner of Stradbally Hall, then presided over the pack. He built kennels at Stradbally, close to his beautiful mansion, but, like his predecessor, Mr. Kelly, he did not long survive his accession. He was a great favourite, and to see him ride was quite a treat; he and his brother-in-law, Mr. Horace Rochefort, the squire of Clogrenan, were about the best men in the county to hounds at this period. The late Lord Portarlington then kept them for a time, and the present Lord Drogheda succeeded in 1847 , and during the three years of his mastership, and with the aid of his most popular cousin, Mr. Robert Moore, an excellent sportsman, hunting survived in a most trying time, although his Lordship did not receive the support he merited from the farmers and landed proprietors of the Queen's County. Simultaneously Lord Ashbrooke hunted the Ossory portion of the country. He was asked to have the packs amalgamated when Lord Drogheda resigned, and, having given his consent, a county pack was established for the first time. He filled the rôle of master but for a short time, and was succeeded by Mr. Hamilton Stubber of Moyne, the father of the present master. He gave great satisfaction, was a universal favourite, and turned out in the best style-in fact, he was the "right man in the right place." 
In I860, Major Carden took the hounds, and hunted them himself, and the horn could scarcely be placed in better keeping. He was keen "to the heel," and let hounds hunt when they could hunt, and assisted them when they could not; but this cannot be said of many huntsmen of the present day, gentlemen or professionals; most of them teach the hounds to rely more on their orders than on their own noses. The Major, although a one-handed man, rode in the firstflight, and with his hounds-never on them.

At the end of 1867 , he resigned in favour of Captain R. Cosby. It would be a great injustice on my part did I not bestow very high encomiums on the gallant squire of Stradbally Hall, who is undoubtedly deserving of the highest praise from, and has a claim on, the gratitude of the lovers of hunting in his native county. For eight years he worthily filled the post of Master of the Queen's County Hounds, and during that time improved very much indeed the country and the pack. He is a first-rate judge of horses, and few masters of hounds in Ireland turned out their hunt-servants in better style. They were always, like their master, very well mounted. Although not a "bruiser," he is a very good man to hounds; he rides not for show, but to be with them, and he seldom fails in his effort. In agricultural pursuits Captain Cosby takes a keen interest, and has the same correct eye for horn and fleece as in the kennel or stable. He is a breeder of first-rate stock-ovine, bovine, and equine-and he has had many show-yard celebrities in his possession. At the annual Horse Show in Kildare-street he is generally amongst the most successful competitors. 
For years past he has been in the habit of visiting most of the important steeplechase meetings held in Ireland, and he is a votary of the illegitimate pastime, although (more's the pity) he does not patronise flatracing. He has never yet been fortunate enough to win a very important race, but his horses have frequently gained "brackets." He has them always trained at home, races purely for sport, and the "white and green hoop" is a very familiar and popular banner with visitors to the Baldoyle, Punchestown and Orchard meetings. The last-mentioned he established himself, and subscribes liberally to the fund every year.

In May, 1876, Captain Cosby resigned, and Mr. R. Hamilton Stubber was unanimously elected master. He has been very successful in his efforts to show sport. He, too, sometimes has a chaser or two in training, and the "French grey and scarlet" has been carried successfully for a few minor races.

The annual subscriptions at present paid amounts to about $£ 1,200$ a year. The number comprising the "field" averages, I-should say, about 25. Lord Castletown, Sir Charles Coote, Mr. Robert Staples, Sir Allen Walshe, Sir Anthony Weldon, Mr. John G. Adair, Viscount De Vesci, the Earl of Portarlington. Captain R. G. Cosby, Mr. T. Skeffington Smythe, Mr. IV. D. Webber, Hon. Bernard Fitzpatrick, Mr. Thomas Kemmis, Mr. J. WV. Dunne, and Mr. Henry Moore are the most liberal subscribers.

In naming the "first-flight" men of the present day, I hope I will be excused if I overlook any person deserving of notice. I shall not do so if possible. The one-armed veteran, Mr. "Charlie" White, for many years enjoyed the cliaracter of being a "leader in the 
van ;" he was pre-eminently entitled to it, and even now, though very many seasons have passed since he first assisted at the obsequies of Reynard, he can, and does frequently, hold a prominent place. Mr. Edward Corcoran, of Raheenduff, Timahoe, is one of the oldest patrons of the chase in the county, a staunch preserver of foxes, and a greater " clinker" never "tallied" one; even now, though his head-covering is slightly blanched with the frost of age, he is often first among the leading lot. His son, "Charlie," inherits the taste for the sport so characteristic of his father, and is a first-class light-weight. In this line of business Mr. Horace Rochfort has acquired such fame that I need not delay to pass any encomiums on him-- "good wine needs no bush." Of Captain Cosby I have already written. Mr. John W. Dunne, of Raheenawhole, is a welter-weight, and is as devoted and fearless a foxhunter as ever rode over the banks of Ossory. Mr. Henry Moore of Cremorgan deserves commendation; and those who are in the habit of visiting the Ballybrophy district must have remarked the brothers Plunkett-Joseph and Oliver-amongst the "foremost hard-riders ;" and Mr. Leech I must also mention. Mr. Edge, in Kilkenny as well as in the Queen's County, has proved himself to be undoubtedly

"A rum 'un to follow, a bad 'un to beat."

Mr. Laurence Kelly of Ballymeelish Park, Ballybrophy, must also be included in the list of "firstflight" men. Before mentioning the names of the gentlemen I should have named one pre-eminently entitled to a word of praise-I allude to Miss Ella Stubber, the amiable and accomplished sister of the 
master. A better horsewoman I have seldom, if ever, seen in the saddle.

Snaith was appointed huntsman in 1874 , and carried the horn until the end of the season 1876.7. His successor, W. Rawle, knows his business, and is a most excellent servant. He has had a great deal of experience. He has an excellent "aid" in George Mulhall, who was whip for a while during Major Carden's régime.

The country is an extensive one, nearly all grass; the fences in many districts very big, and the banks faced with stones. I may certainly call it a fair hunting-country.

There are now (Nov. 1877) $43^{\frac{1}{2}}$ couple of hounds in kennel; drafts from Lord Doneraile's, Curraghmore, and Carlow and Island Hounds, and from English kennels. They hunt twice a week, with an occasional bye-day. 


\section{CHAPTER XVIII.}

THE LIMERICK STAGHOUNDS, DUHALLOW, AND LISSNAGON HOUNDS.

I REGRET very much that I cannot give a more lengthened and accurate history of the Duhallow Foxhounds. I failed to procure the eagerly soughtfor details. I believe them to be the oldest established pack in Ireland, and a covert which was given up within the last few years only, Portnarhea, was taken at a rent of twelve guineas per annum in the year I 745, which fact shows the antiquity of the country. The hounds came into the possession of Mr. Wrixon of Ballygiblin, the great-grandfather of the present Sir Henry Wrixon Becher, about the end of the last century. On Mr. Wrixon's retirement, his son hunted them for many years; and after his death, the present Sir Henry's father, Sir William Wrixon Becher, was master for several seasons. He was a splendid horseman; and during his term of office the hunt became very popular. When he gave up the management, he was succeeded (about 1830) by Mr. Robert De la Cour of Mallow. He was in command for a long time, and, from his knowledge of the country and popularity, his career as master was a most successful one. $\mathrm{He}$ spared no expense in his endeavours to show sport, and it was only on finding his sight failing that he 
resigned. After Mr. De la Cour's resignation, Mr. John Courtenay hunted the country for a few seasons. When he sold his hounds, the present Lord Doneraile hunted it; he kept the hounds at his seat, Doneraile Ccurt, for some years. Then his Lordship went to live in England-where he hunted the Burton country for some time-the Duhallows were managed by a committee; the late Captain Leader of Mount Leader was field-master. In 1876, Mr. T. G. Hare became master, and has had them ever since. It would be difficult to find one more thoroughly desirous of showing sport, more popular or more sportsmanlike in all his acts.

The best part of the Duhallow territory is towards Liscarroll, a very fine grass-country, undulating with large grass banks; no big woodlands, in fact no coverts of any sort, except a few gorse coverts. The "cream" of the country is that portion from Clonee, Kilberehert, Killanane, Ballybane, Knockmacolon, \&c. On the south of the Blackwater it extends as far as Blarney, where it joins the Muskerry district. That country is more stony and cramped; but it is a good, wild district, and there are plenty of foxes there. "Take it for all in all," the Duhallow is a fine hunting. country; and any well-mounted man, who will ride straight, can go wherever the hounds go, in fact, ought never to lose sight of them, as there are almost no unjumpable fences, except on the north eastern side, which never shows much sport. If the Duhallow territory could be extended a little in one or two directions, so that it could be hunted four days a week, it would be one of the first fox-hunting countries in the world. Unfortunately, the earth- 
stoppers have more than enough to do, owing to the great number of sewers and drains, as well as limestone rocks. The coverts are mostly small patches of gorse; there are only a few big woodlands. The principal supporters of the hunt are: the Earl of Listowel, Sir Harry Becher of Ballygiblin, and Mr. Richard Longfield of Longueville. There are generally thirty-five couple of hounds in kennel. The pack consists mostly of old Duhallow hounds and those purchased from Lord Shannon, when he gave up the "United Hunt." The Duhallows hunt nominally two days a week, but generally three. The kennels, which were built a couple of years ago, are at Cortigan, near Mallow ; P. Dalton is huntsman, C. Burns and T. Hayes, whippers-in. There are two or three packs of harriers kept in the neighbourhood of Mallow; and excellent accommodation can be had in the town for man and horse.

\section{THE LIMERICK STAGHOUNDS.}

Stag-hunting, or "catching your own again," as Sam Nicholl called it, is becoming more popular in Ireland every day.

In 1872 , Mr. John Gubbins of Bruree House, Kilmallock, formed the pack now known as the Limerick Staghounds. They are a very good lot of hounds, bred from the Limerick, Lord Shannon, and the Curraghmore kennels. There are now twenty couple in kennel. They hunt two days a week, over a splendid grass-country. The "field" generally numbers about forty. The master is well supported, particularly by The O'Grady of Kilballyowen, and Mr. George 
Furnell of Fort George, who place their deer-parks at Mr. Gubbins' disposal. Mr. Furnell is a sportsman "to the manner born;" several of his ancestors were noted sportsmen. I think it was Mr. George Furnell's grandfather, a near relative of his, at all events, who kept a pack of buck-hounds, and hunted in the county Limerick during the "thirties." $\mathrm{He}$ purchased them from Mr. Tuthill of Faha, who had them for many years. They were the only pack of the kind in Ireland, and were the largest hounds in the world; mostly all of a glossy white, and they used to go at a tremendous pace. They were rare bred hounds; the strain belonged for centuries to the Massey family, and were kept for running red-deer on the Galtee mountains and glens of Aherlagh. Tradation has it, that George the Third offered Mr. Massey a very large sum of money for them. Mr. Gubbins is a very devoted patron of hunting and steeplechasing, and a very popular sportsman. He is a good man to ride, and sported silk more than once successfully. He hunts the hounds himself, and has shown first-rate sport to his grateful neighl)ours ever since the pack was formed. He always has a very good stud of hunters. D. Hogan is kennel-huntsman and first whip; John M`Grath assists him.

\section{THE LISSAGON STAGHOUNDS.}

Mr. A. E. Humphrys of Lissagon House, Ballyhaise, county Cavan, keeps the above-named pack entirely at his own expense. He has twenty-four couple of dwarf foxhounds, bred from good kennels, such as Lord Paltimore, Sir V. Corbett, Mr. Shirley, and Mr. King 
(Ballylin). The hunting days are Tuesday, Thursday, and Saturday. The pack was originally formed, owing to the scarcity of hares in 1874 , for the encouragement of sport in the district of Ballyhaise and Cavan, as no hounds hunt in the immediate neighbourhood, the Cavan Harriers usually hunting near Killeshandra, ten miles distant. Mr. Humphrys' hounds hunt deer and hares on alternate days. $\mathrm{He}$ carries the horn himself; J. M'Mahon is kennel huntsman and first whip. That Mr. Humphrys is a good sportsman is proved by the fact that he has spent a large sum of money in connection with the hunt, and has adopted a system worthy of commendation: thirtytwo farmers have been appointed gamekeepers, at $£$ I each per annum, to preserve the "fur;" and the country was well stocked last season, as the master turned down sixty-eight hares; but the poachers killed a great number of them during the summer.

A handsome presentation was made last year by the hunting gentlemen of Westmeath to him, in recognition of the sport shown with his hounds in that county, when, in acceptance of an invitation given by some gentlemen and farmers, he brought them to Mullingar, with six fallow and two red-deer, and gave six very good days' sport. The presentation consisted of a silver hunting horn with a gold mouth-piece; it bore the following inscription:-

"Presented to A. E. Humphrys, by his sporting friends in Westmeath, as a memento of his visit to that county, with his staghounds, in $1876 . "$

A very handsome gold-mounted hunting-whip, and patent safety stirrup was presented to Mrs. Humphrys, who always rides well, and is very fond of hunting. 


\section{CHAPTER XIX.}

THE KILKENNY HOUNDS.

READER, it was during Christmas week that I visited an old and valued friend in Kilkenny county. It was a right merry time, and yours truly felt as comfortable and gay as need be, when, after riding a good run, on a perfect hunter, over the Freshford country, he found himself with his legs stretched under the mahogany of his kind host, and doing justice to his hospitality. The ladies had retired to the drawing-room, and were talking, probably, of the many estimable qualities of absent friends of their own sex (they always do, you know), of the latest fashionable intelligence, or the marked attention of Harry Hiover to Bella Dashaway. The "youngsters" made their exit after dessert to quarrel over sugar-plums and Christmas gifts, while myself and a few more lovers of foxhunting remained chatting over the events of the day, the likelihood of Jack Frost interfering with our hunting manœuvres, and other kindred subjects. It was a fearful night; Boreas was as rude as possible; Fupiter Pluvius had laid on the main, and the rain rattled against the window-panes so loudly that it caused the fox-terrier, stretched on the hearth-rug, to growl at the interruption to his peacelul slumbers. 
We cared little for the elements; they added, perhaps, to our enjoyment, made us feel all the more cosey, and appreciate more fully our host's good cheer.

Such was the state of affairs, when the conversation I will now endeavour to relate commenced between my Kilkenny friend and myself.

"Come," said he, "pass the decanter; the sherry is dry; and tell me how you are getting on with that work of yours, which I heard you speak of, "Irish Sport and Sportsmen." ",

"I am working at it; but it is not easy to obtain the desired information, and it is difficult to place the histories of the different packs of hounds in readable form, you know ; however, I won't 'bolt ;' you may be sure I will try at all events; and if my work possesses little merit, I can claim for myself at least the creditif any is due-of being the first to attempt the bringing out of a book purporting to chronicle Irish, and only Irish, sport. In offering it to the public, I am not influenced by a desire to acquire literary notoriety, and I hope the critics will be more merciful than just. And I must ask you to give me what information you can relative to the Kilkenny Hounds and country."

"I shall be most happy; but, as I said before, try a glass of sherry, or an S. and B., or, better still, a tumbler of punch, 't will oil the springs of conversation."

"I will, with pleasure; but, perhaps, I had better get your stock of detail at some future time; you are anxious to join the ladies I am sure, as I saw you paying marked attention to one who is now under your roof."

"Oh! no, my dear fellow; but I am one of those 
who believe in the words of that little song you often heard :-

“With a pretty face close to your own,

I am sure there's no reason for sighing,

Or when walking beside her alone,

Why the $\mathrm{b}-\mathrm{s}$ be talking of dying ;

That's the way though in France and in Spain,

Where love is not real but acted;

You must always pretend you're insane,

Or at least that you're partly distracted.'"

"Well sung; but favour me with what you know about 'your pack,' and then I will call on you for a song."

"The Kilkenny Hunt was formed, close on a century ago, by John Power and his brother Richard of Tullaghmaine Castle, county Tipperary. John Power-afterwards Sir John-took up his residence at Derry, near Ballyhale, and here he formed the Kilkenny pack. No man did more for fox-hunting in Ireland than he, and the proof is he made the Kilkenny country; he fenced in its coverts, had patches of gorse sown in every suitable place, and formed the Kilkenny Hunt Club."

"It was a very select club, was it not?"

"Yes. The members met in Kilkenny in the months of November and February every year. The leading sportsmen of all Ireland attended these reunions. It is so long ago it is not easy to ascertain the names of the principal members; but Sir Wheeler Cuffe, Sir Nicholas Ruftus, Mr. Bayley of Norelands, Sir R. Cox, Bart., Messrs. Montmorency, Ponsonby, and Cooke, were great supporters, as was nearly every gentleman in the county. I should add too the name 
of Sir Hercules Langrishe, who was a great supporter and good sportsman. Sir Hercules was, in more than one respect, a very notable Irishman and wit. He played once, in the then famous Kilkenny plays, Sir Lucius O'Trigger, when Tom Moore (of the Melodies) took some minor part. Riding with a Lord Lieutenant in the Phœnix Park-I think Lord Anglesey-the Viceregal steed slid in a pool of water, and nearly unseated the rider: 'Why the devil don't they drain the park?' said his Excellency; 'Ah!' quoth Sir Hercules, 'they're too much taken up in draining the rest of the country.' The Viceroy chuckled, so did Sir Hercules. There used to be great fun at the hunt dinners; sportsmen from every county used to come down for a week; officers used to come from Dublin, Cork, and other places too. Young fellows on for all sorts of fun. 'God bless the boys!' said a Crimean Brigadier. 'How they bruised and boxed, laughed and lushed, fought and philandered; and, by gad, sir, they were not milksops or mollycoddles.' When Sir John Power went to live at Kilfane the hunt gained great notoriety, and sportsmen from distant counties used to come to hunt in Kilkenny."

"Who was huntsman to Sir John?"

"Byrne-a first-rate man at his business-was his first; Con was whip to him. After some years, Byrne was succeeded by a most popular man, an adept at the profession, indeed, Sir John would have no other; his name was Robert Comet. He came from Lord Yarborough, and brought with him three hounds from that kennel-Grabbler, Graceful, and Gracious-and from this stock were bred most magnificent hounds of the true foxhound type. Mick Butler was first-whip 
and Denis Dwyer second at this time. It was no wonder that the pack soon became perfect; no man understood the breeding and condition of hounds better than Comet."

"Who succeeded Sir John as master?"

" His son 'Johnnie,' as his friends called him. Soon after he got them, poor Robert Comet died of aneurism of the heart; and the first whip, Mick Butler, was promoted to the vacancy, and Stephen Goodall was appointed whip. You've heard of him, I dare say."

"Heard of him! you forget you're talking to a Kildare man; of course I have; who has not? $\mathrm{He}$ was a splendid horseman, and had a grand voice. Who succeeded Butler?"

"After a couple of years Sir John hunted the hounds himself, with Butler and Goodall as whippersin."

"He showed good sport, I believe?"

"Very; he was a keen foxhunter, a fine horseman, and a most popular man with all classes-and so was every member of his family."

"The late Baronet was fond of steeplechasing too, I understand?"

"He was; he had some fair horses; and a mare of his, Fox, was second for the Corinthian Cup in Punchestown in 1857; she was ridden by Captain Townley, and was beaten by Colonel Forster's Ringleader by a neck."

"I heard that the late Sir John built kennels at Kilfane."

"Oh, so he did. I should tell you that the present Baronet, Sir Richard, is very popular with all classes, 
and deservedly so; and Lady Power is a great favourite, not only with those of her own position, but also with the poor in the neighbourhood of Kilfane, to all of whom she is most charitable and kind."

"So I often heard; and I remember that they lived for a short time in Kildare, at Sallymount, a pretty place, near Harristown; and I can assure you that they were much liked by all in that county, indeed they are wherever they are known. Does Sir Richard keep racehorses?"

"Not now; he had a mare named Stella; you must have seen her run in Punchestown, and carry his colours successfully too!"

"Oh, yes, I remember now; in $187 \mathrm{I}$, she ran second for the Drogheda Plate ; just got beaten by a neck by 'Dick' Bell's mare, Rosette; it was a great race; next day she won the Railway Plate, ridden by 'Paddy' Gavin; and on the following day she was sold at Sewell's to Mr. Burton Persse for 144 guineas. Sir Richard Power has not had a racer or chaser since he sold Stella, and I'm very sorry for it, as the patronage of a gentleman of his position and character would be a great acquisition to the Irish turf."

"Excuse me, but I know that if you commence to talk about racing you won't stop for hours, and I am anxious to give you all the information I can now relative to the Kilkenny Hounds."

"Well, I am all attention. Who succeeded Sir John Power?"

"Mr. George Bryan of Jenkinstown."

"He has been member for the county for many years, has he not?" 
"Yes, since 1865 . He is the only son of the late Colonel George Bryan of Jenkinstown, and was born in $1828 . "$

"How long was he master?"

"Mr. Bryan assumed the mastership in May, I850, and kept the hounds for two seasons. Denny Callaghan was huntsman during the first season, and Tom Mathews hunted them the second; the sport continued to be very good while Mr. Bryan had them. $\mathrm{He}$ is very fond of hunting, and rides well to hounds too, as indeed he did between flags, when he sported silk, as was his wont some twenty years since."

"He kept a large stud of race horses some years ago, I believe?"

" He did, and had many 'clinkers' too. There used to be a very good race-meeting held annually in Jenkinstown Park some years ago. Many a grand race I have seen there."

"Did Mr. Bryan keep a large stud in training in Ireland?"

"No; he used to race horses at the Curragh occasionally; but Jenkinstown was his favourite meeting. You know he was a patron of the English turf for years, and was fortunate enough to win some very valuable stakes.

"Lord James Butler, uncle to the present Marquis of Ormonde, succeeded Mr. Bryan, and had the hounds for a season. Purselaw was then huntsman. Lord James's name reminds me of a steeplechase which he won at Whitefield in $185 \mathrm{I}$. Five horses, carrying 18st. each, ran. Lord Butler rode his own horse, Freebooter; Mr. Bryan was second on his grey, Blue- 
skin; Mr. Kellet third, on Mayboy; Mr. Cronnin on Mr. Prendergast's Woodman; and Mr. William M'Grane (Montpelier-Hill, Dublin), on Mr. Smithwick's Sampson."

"After Lord Butler resigned, the hounds were kept by a committee for a season or two, I believe?"

"Yes; and then, in 1856 , Lord St. Lawrence (now Lord Howth) took them; he got on very well, and was master for five years. We all know how fond of the 'noble science' he is. I never saw a better rider to hounds. He was always well mounted, and most courteous to all in the 'field.' Colonel Richard Bernard was his Lordship's right-hand man, and took up the mastership on any day when Lord St. Lawrence might be absent. Some of the sporting deeds of the Colonel, at this time, were worthy of his fame as a horseman, and the recollection of them is often very fondly dwelt upon by the many friends he made during his sojourn amongst the 'boys of Kilkenny.' Lord Howth secured the services of very good men. For instance, George Jones, and after he left, Pat Cody was appointed huntsman, and Jem Monahan was first-whip."

"The trainer who now lives at Hawthorn Lodge, the Curragh, and who rode so many good races? For how many years was his Lordship master?"

"Mr. H. W. Meredyth of Norelands succeeded his Lordship in 186I. The first huntsman he had was Wm. Boxal, who hunted them for four years, then Walter Bell, who remained for one season. Mr. Meredyth carried the horn for two seasons, but finding the work too hard, he got Richard Scarth, who subse- 
quently hunted the Kildare Hounds. Mr. Meredyth retired, in 1870 , on account of great dissension and very unpleasant circumstances having occurredpoisoning of foxes, burning of coverts, and every annoyance was given to the hunting-men and general well-wishers of fox-hunting. A very unpleasant paper war was carried on for some time about $\mathrm{Mr}$. Meredyth's conduct by several members of the hunt, and very severe strictures were passed on his management. Some of the members signed a requisition to have him to continue as master, and promised him their support. But many were anxious for his resignation, and the sport during the last two or three seasons of his régime was very bad; and when he resigned the members advertised for a master, and for some months there was no reply. The members of the hunt and farmers were most anxious that Henry Briscoe would accept the hounds. After the death of Henry, Marquis of Waterford, he kept the Waterford Hounds, and hunted them for eleven seasons; the present Marquis came in for the title just about the time that Mr. Meredyth gave up our hounds, and the Marquis being anxious to re-establish the Curraghmore, Briscoe gave up tine IVaterford, and soon afterwards took the Kilkennies."

"Tell me, did Mr. Briscoe hunt the Waterford Hounds himself?"

"He did for a few years only; and no gentleman or professional could do it better; Duke, now huntsman of the Curraghmore, was his first whip. When he became master of the Waterford Hounds, he deemed them too high on the leg and flat-sided, and 
immediately set to work to improve them; and by the influx of new blood, the best that could be got, he soon got together a splendid lot of hounds, with short legs, great length, and good neck and shoulders; and the present noble owner has often complimented him on the grand pack he handed over to him."

"Mr. Briscoe kept the Kilkenny Hounds to the end of the season, 1875-6, and then the present master took them ; is not that so?"

"Yes; the master who now has them, Colonel Chaplin, has given great satisfaction, and, I am sure, he will continue to do so."

"He was Colonel of the 4 th Dragoon Guards, was he not?"

"Yes."

"Briscoe improved the Kilkenny Hounds, too, I am sure?"

"Indeed he did, very much; and you seldom, I think I may say you never, rode after a finer pack than you did to-day."

"I admit they justify your praise."

"I am sure of it; and not only Kilkenny, but the fox-hunting world, must admit that no man has done, or could have done more, than Mr. Briscoe has done to save the Kilkenny Hunt, and to bring the pack back to its former prestige."

"He must have known a good deal about hounds and hunting when he took the Waterford Hounds, or he could not have hunted them so well and improved them so much."

"So he did; he was born in 1810, and after graduating in Trinity College, Dublin, in 1828 , he 
regularly hunted from that time a pack of hounds kept by his father, till that gentleman's death, in 1834; so you see he was 'entered' to his game early in life."

"I often heard that he was a very good horseman, and I know, from reading the Calendar, that he had many good chasers, and rode in several Corinthian races when young."

"He had a few good horses, and won several races; he won a good many with a mare he had by Economist."

"Hadn't he a horse called Wedge, too ?"

"Yes; and the last time Mr. Briscoe 'sported" silk was on Wedge, for a steeplechase at Whitefield."

"How many ran, and what was the result?"

"Wedge, and Lord Waterford on Regalia, John Power of Gurteen on Polka, and Lord Desert on Rufus. Regalia won by a length; but had not Wedge met with a mishap, he would have won; as it was, he was only beaten by a length. Briscoe is the only one now living of those who rode in that race. I forgot to tell you, when speaking of Jenkinstown, that a horse of his, Field-Marshal, a son of Red Hart's, won the Lottery Plate there in $1860 . "$

"Didn't he import Red Hart to this country ?"

"He did, and several other good sires. He did as much to improve the breed of horses in Ireland as of hounds; he imported from England, Glenmasson, the sire of Emigrant, winner of several races, and Legatee, sire of Pale-star, Mr. Moffat's horse; you have heard of him?" 
"Oh, yes; and have often seen Mr. J. D. Whyte win races on the "lovely little black." "

"Greatheart was the best horse Briscoe imported, and got the best cattle we ever had in this part of the country. He was the sire of Ace of Hearts, winner of the Corinthian Cup in Punchestown in $185^{8}$. You must remember that race, as your father's horse, Phœnix (late Patrick), was second to him."

"I remember; and, I believe, Ace of Hearts ran a great race at Carmarthen in 1862 ?"

"Yes; he was then the property of Mr. Powell ; it was for the Carmarthenshire Steeplechase, four miles over a big country, and The Rug, a horse belonging to Captain Tom $\mathrm{M}$ 'C $\mathrm{Craith}$ of Loughloher ran two dead heats with the "Ace." "

"Well, what was the result? Sure'y they did not start them again after running eight miles?"

"No. Night coming on, they agreed to divide, and Ace of Hearts walked over next day. Mr. James rode him in the first heat, and poor George Stevens in the second. Jem Monahan, the whip, of whom we have just been speaking, rode The Rug."

"I am glad to hear that Mr. Briscoe is to be presented with a testimonial by the sportsmen in your neighbourhood here; no man is more deserving of it; and, I am sure, it will be a very magnificent one."

"It will indeed; every foxhunter in the county will subscribe."

"Who are the most liberal subscribers to the hunt fund?"

"The Marquis of Ormond is a princely subscriber; and Lord Bessborough, Lord Clifden, Captain Pon- 
sonby, Sir Richard Power, A. Flood, C. Wandesforde, George Bryan, M.P., H. W. Meredyth, the Smithwicks, Sir J. Langrishe, and Colonel Tighe, are all good supporters."

"Will you kindly tell me who are the "firstflight' men, or rather first mention who were years ago ?"

"Mr. Clayton, Wm. Bayley, Sir Richard Cox, Sir John Power, Robert Hammond, Horace Rochfort, Henry Briscoe, Edmund and Richard Lalor, H. Flood, Robert Walshe, and John Wade. Those who generally form the leading brigade now I will tell you as you have asked; but you know I may unintentionally omit some entitled to be included. However, I will be as candid as possible. H. W. Meredyth, Sir Richard Power, Major Bunbury, Lord Waterford, George Bryan, our 'member,' and Thomas Lalor. Mr. Edmond Smithwick used to go pretty well too; he had a grey horse, 'Sam,' a great performer. He was killed in the hunting-field a few years ago. Mr. Smithwick has had his head preserved, and his hoof magnificently mounted in silver, and formed into a stud-case, was presented to him by Mr. George Bryan and the Hon. Major Whyte-Melville, on the lid of which are engraved the following lines, composed by the latter gentleman :-

"In the corner of the stable there's a lone and empty stall; There's a snaffle and a breastplate hanging idle on the wall ;

There's a hoof on the chimney, that was foremost in the van, And gazing on it-mute and sad-a sorrow-stricken man. 
His heart is aching with a void that never shall be filled,

For the fav'rite he loved so well-the fav'rite that he killed;

Through the bounds of fair Kilkenny, though he search its hill and plain,

Ned Smithwick cannot hope to find so good a horse again.

Bank, wall, or ditch, no matter which, he landed safe and clear,

And 'change' or 'kick,' would do the trick, and jump it, never fear;

The fence could not be strong enough, nor long enough the day,

No hounds could race too smart a pace for 'Sam,' the gallant grey.

To E. SMithwick,

"From Whyte-Melville and George Bryan."

"From what kennels are the hounds bred, and how many couple have you?"

"They are bred principally from the Yarborough, Foljambe, Grafton, and Beauford kennels. We have fifty couple of hounds, and Mondays, Wednesdays, and Fridays are the hunting days."

"Who are the hunt-servants? Your huntsman evidently knows his business, and does it too.

" Jack Tidd is huntsman, and you have judged him rightly; he graduated under Duke with the Curraghmore William Quinn is whip, and the kennels are situated near the city."

"Well, what about your country?"

"I may describe it as being a good hunting and a capital scent-holding one. The coverts are nicely situated. You require a good fencer here, as you 
meet plenty of big banks, many of them ragged and faced with stones, and in places very big and wellbuilt walls. Your nag must be a good wall-jumper; he need not be very good at timber-topping, as you seldom meet that kind of fence; and though the 'moon looks on many brooks' in the territory, they are not very formidable obstacles. Many noted sportsmen, residing in distant counties, send their horses to be trained to jump in Kilkenny, chasers as well as hunters. It is a fine grass-country, and is more free from that bite noir of Irish hunting-bog than any hunting-district in Ireland, not even excepting Kildare. And now you have exhausted my stock of information on this subject, and I will therefore recite for you some lines which were written about the Kilkenny Hunt of fifty years ago, as I daresay you never heard it."

"I never did, but will be glad to; so give melody the 'office' to go."

\section{“THE KILKENNY HUNT FIFTY YEARS AGO.}

"What a meet! I remember one glorious spring mornOur hearts beat with joy at the sound of the horn!

The breakfast at Rice's* was sumptuous, but short, For all were most eager to join in the sport.

Harry Lorrequer's herot we think of with pride, And his sister, a Willett, they rode side by side, Disdaining restriction and feminine fear,

She so loved the hunting, and always was near.

Next Massey from Glenville- how noble his mienHe enjoyed a good fortune, was mate for a queen;

And Fosberry, $\neq$ ' Red George,' with a brogue as rich quite, Keen folk, these were welcom'd with cheers of delight.

- The present Club-house Hotel, Kilkenny,

+ Major O'Flaherty.

$\ddagger$ Master of the Limerick Hunt. 
Then Magennis rode hard when the work it got warm, Though, like young Ambrose Power, he was minus an arm; The young gov'nor* rode Watty; Sir Wheeler-stanch rockRode a tight horse, a son of the famed Hollyhock. Big Bayley, on Giant, made two giants there, Yet his eyes and his head they were felt everywhere ; Young Cooke, on his grey, from Kiltinan, did well ; These, with Fowler and Watson. + all met at Dunbell. Time was up, 'into covert,' and clear through they go ; 'Not at home,' said Sir John, 'twas thought it was so. We were leaving in groups, but blind Nixon said 'No!' Blind men's poems and travels we cannot deny, But a blind, forward horseman, was rare to the eye. 'There's a hound still in covert,' said Nixon, 'he's here!'

What the blind want in sight they make up in the ear. Old Byrnef put them in. 'Hark to Warwick!' he cried, For Warwick, old hound, was his boast and his pride.

Next moment ' away!' Warwick still at his brush, For 'twas Warwick was heard as the hound in the bush. How soon we reached Clifden; the railway alone Would convince in these days that the thing e'er was done.

From Clifden to Bishopslough, thence to Kilfane, But, well stopped out there, he next made for Greenane, Though he neared Thomastown when he changed his old route, Ran towards Coppenagh hills to baffle pursuit : But, pressed hard by the ever-true pack, this good fox Wheeled short round to Dangan, and earth'd neath the rocks. The field was select, but with skill and with speed, Sir John was the first with the hounds in their need; The picture so gorgeous, from Dangan's full height, Had wrapped me in wonder, amaze, and delight; Then the gallant Sir John cried out, 'Yonder's Brown's barn ;' And so finis I put to the end of my yarn."

"Thank you ; very good; as you won't let me off, I will respond to your call, and sing you a song I composed after a good run with the Ward Hounds. I never sang it before.

\section{"A RUN WITH THE WARD HOUNDS.}

"Come, boys, fill each glass on the table, And push the decanters about, While I give an account, if I'm able, Of a run the last time we were out;

* The late Sir John Power, Kilfane. t The master of the Carlow Hunt. \$ The matchless old huntsman. 
Since the day that the plucky Lord Spencer

Took the 'Wards' famous dyke in a fly, Such value we never had since, sir-

'Boyne Water' left some of us dry. Hip, hip, boys! a bumper, hurrah ! Give each his well-earned rewards ; Success to the men who to-day Upheld the old fame of the Wards!

"Charlie Brindley laid on his fair 'beauties,' Melodious they gave out the 'pay,' No huntsman more strict to his duties, Success to himself and his grey; Jameson flew in advance o'er a rasper, With brave Leonard Morrogh before, Who never yet opened a hasp, sir, Spikes and all he goes fearlessly o'er. Hip, hip, boys, \&c.

"Joe Hone, like the famed Galway Blazer, On his bay leaves the rest in the shade; He could land on the edge of a razor, And not leave a gap in the blade;

With Murland now close on his quarter, And Watson enjoying the fun;

Though the ground be as holding as mortar, They are found in the front of the run. Hip, hip, boys, \&c.

"See Harper, and Trotter, and Meldon, With Kearsley are running a race; Bravo! my young soldier! faith, well done; You'll ne'er bring the Guards to disgrace.

There go Kennedy, Butler, O'Reilly, The deer keeping well in their view, While Mat Duffy gains on them so slylySure he knows every fence round Kilrue. Hip, hip, boys, \&c

“There M'Donald, D'Arcy, and young Christie M'Grane,

You may see in the thick of the fray'; While M'Donogh skims over the plain, Light-hearted as ever, though grey, 
Turbett, Leonard, and Gavacan are here,

Sailing on without hindrance or trouble, Young Bob M'Garry comes on with a cheer,

And lands beside Nurphy, across the big double. Hip, hip, boys, \&c.

"See bold Duckett, who ne'er looks for gates,

Of the run he can give the best summary; Nor omit the invincible Bates,

Girth to girth with kind Captain Montgomery. Fair, too, as the niece of St. Kevin,

Were Eve's daughters, the foremost beside, If the run of their presence were riven,

But dull were the sport at Kilbride.

Hip, hip, boys, a bumper, hurrah!

We must all bow, plebeians and lords,

To the conquering heart-binding sway

Of the beautiful maids with the Wards."

"Bravo! and now with your assent we will join the ladies; but fill your glass before we go."

"I will, and I thank you for the information you have given me. I am glad to hear that fox-hunting is popular in Kilkenny. May it be so long after you and I are put to ground, and I hope that day is far distant. Do not imagine when you see 'Irish Sport and Sportsmen,' with the history of the Kilkenny Hounds, given in the last chapter of my memoranda of the chase, that I placed the packs in the order of merit. I thought it would be invidious to attempt to do so. I have mixed the best and the worst up and down, and just forwarded the histories for publication according as I had them ready. I wish you many happy returns of this festive season. The holly and ivy which we see here before us represents summer in winter to the young foxhunters in the county; particularly to that good young 
sportsman, Sir Richard Power, I wish the perpetual youth which is therein typified; to him and his ancestors every votary of Diana in your county is indebted. May the old ones, especially that true and veteran sportsman, Henry Briscoe, be, like our beloved island, 'ever green.' Long may they wave. And now we will adjourn and see what fair lady we may catch under the mistletoe." 


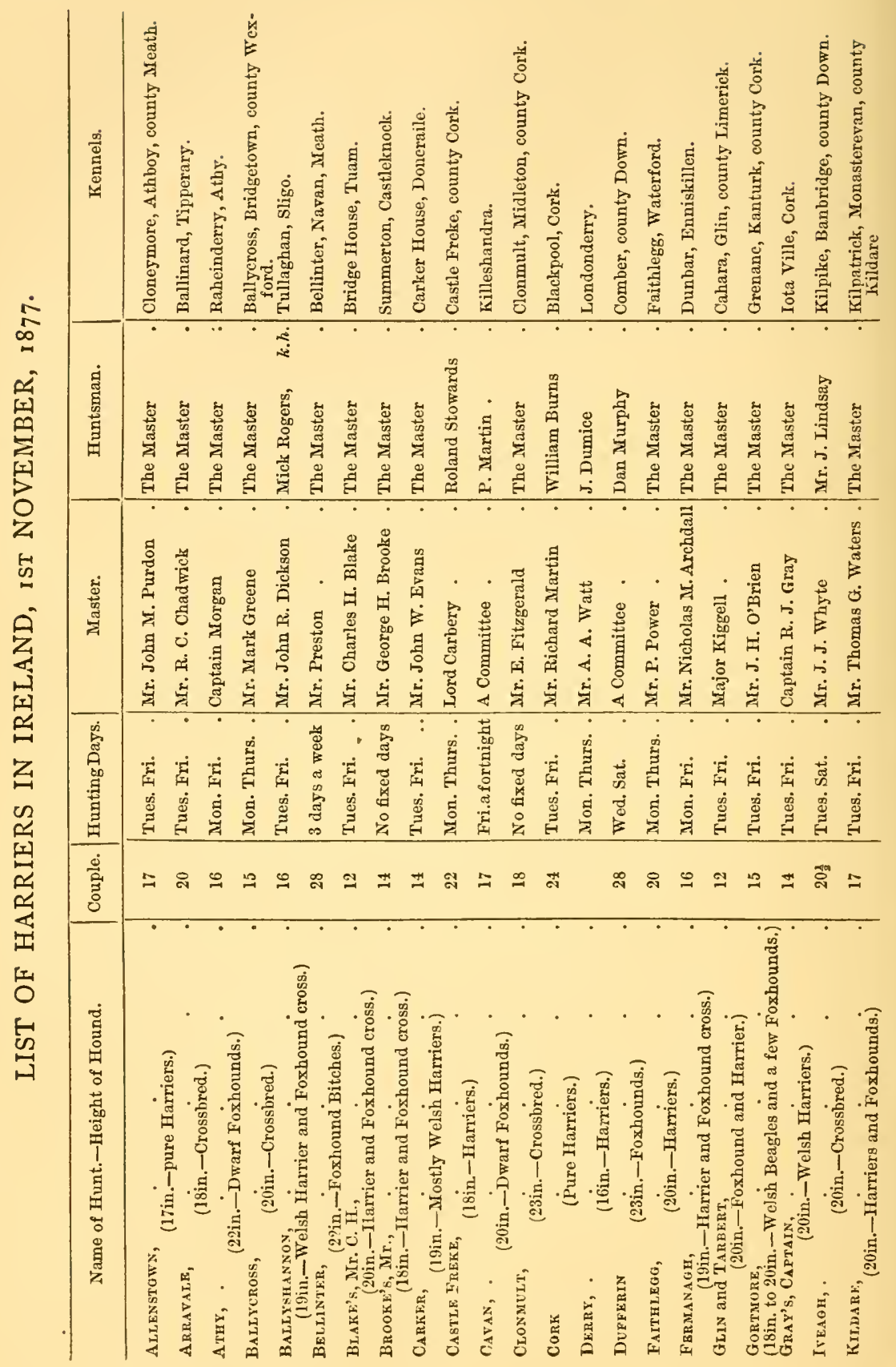


LIST OF HARRIERS.

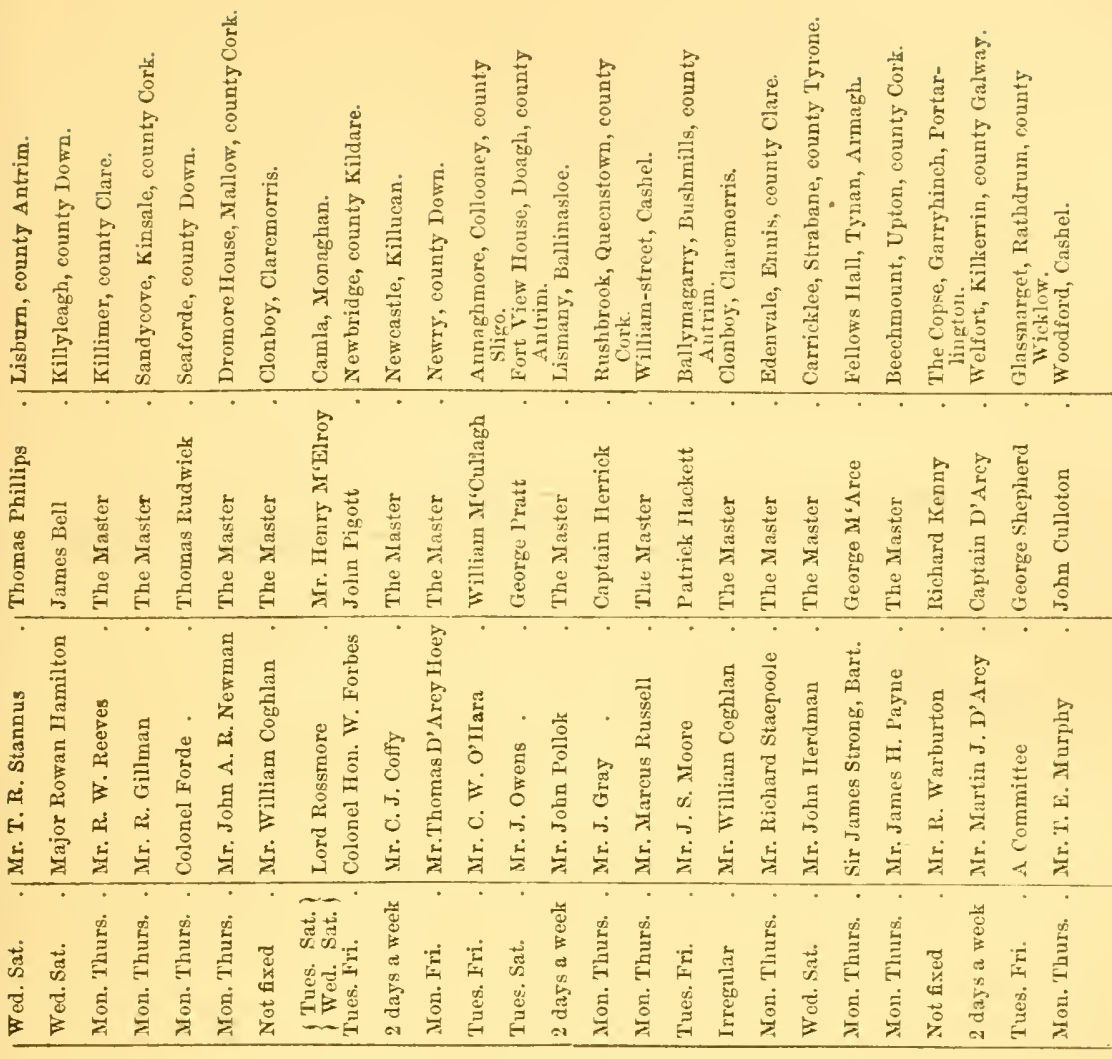

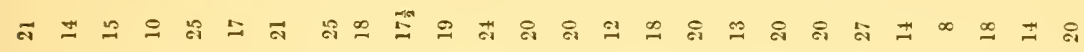



PART II. 

PART II.

"STARS OF THE IRISH TURF."

\section{CHAPTER XX.}

HENRY, THIRD MARQUIS OF WATERFORD.

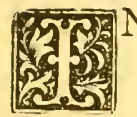

commencing to write biographical sketches of some Irish sporting worthies, the first name that occurs to my mind is that of Henry, third Marquis of Waterford, one of the brightest ornaments of the Irish turf. I have no doubt that the following brief sketch will be read by many, who will pardon any defects for the interest attaching to the subject.

The Beresford family has long been celebrated. In all branches of Her Majesty's service some of its members have earned fame. As statesmen, in the senate house, and at the bar; as soldiers, sailors, and sportsmen, many of them have gained celebrity. Henry De la Poer Beresford, K.P., Marquis of Waterford, Earl and Viscount Tyrone, Baron Beresford, county Cavan, and Baron De la Poer of Curraghmore, Waterford, and a baronet, and Baron Tyrone of Havesfordwest, county Pembroke, in the peerage of England, was born April 26th, I8II; succeeded his father, as third Marquis, July 16th, 1826; and died, March 28th, 1859. Creations:-Baron De la 
Poer (by writ), 1375 ; Baron Beresford and Viscount of Tyrone, 1726; Earl of Tyrone, 1740; Marquis, 1789; Baronet, 1605; Baron of Tyrone in Great Britain, I786. The surname of Beresford, or, as it was formerly written, Bereford, was assumed from Bereford, in the parish of Alstonfield, county Stafford, of which manor, John De Bereford was seised in 1087 (first William Rufus), and was succeeded therein by his son, Hugh De Bereford, from whom lineally descended the deceased nobleman.

Amongst the ancestors of the late Marquis, we find Thomas Bereford, Esq., who resided at Newtongrange, in Derbyshire, during the time of Henry VI. and Edward IV. With the former of these monarchs he served in his French wars, and, according to tradition, mustered a troop of horse in Chesterfield, consisting alone of his sons, his own and their attendants. He had sixteen sons and five daughters by his wife, Agnes Hassel of Arcluyd, Cheshire. Sir Tristram Beresford of Coleraine, Knight of the Shire for Londonderry, in the Parliament of I66I, was created an Irish Baronet, his father having, in the reign of James I., settled in Ireland, as manager of the new Plantation in Ulster, for a Corporation of Londonderry. Another Sir Tristram commanded a troop of foot against James II., and was attainted by the Parliament of that monarch. Sir Marcus, who married, in 17 I 7 , Catherine Poer, Baroness De la Poer, daughter and heiress of the third Earl of Tyrone, in consequence of that alliance was advanced to a peerage in Ireland. The most ancient writs to be found in the Rolls Office of Ireland are that by which Nicholas Le Poer was summoned to Parliament as 
Baron Le Poer, in 1 375, and thrice afterwards, Richard, who was created Baron of Curraghmore, by Henry VI., in 1452. The third Earl of Tyrone became attainted on account of his attachment to the fortunes of James II., and to the House of Stuart. His widow, Anne, Countess of Tyrone, a high-spirited and shrewd lady, sought the favour of the reigning powers, and, in $17 \mathrm{I}$, presented a petition to Queen Anne, on behalf of herself and Lady Catherine, her daughter (then a minor, and afterwards married to Sir Marcus Beresford), praying that the estates might be secured to them by Acts of Parliament. The petition was granted, and an Act passed accordingly. The Beresford family were strenuous supporters of the House of Hanover; and Sir Marcus Beresford, who married Lady Catherine Poer (or Power), sat in the Irish Parliament for the borough of Coleraine.

In 1770, John De la Poer, barrister-at-law, was a Commissioner of the Revenue in Ireland, and presided for many years at the board. In 1772, he was appointed "taster of the wines" in the port of Dublin, and sworn of Her Majesty's Most Honourable Privy Councillors in ${ }^{-G}$ reat Britain and Ireland.

Henry De la Poer Beresford, father of the third Marquis, was a Knight of St. Patrick, a Privy Councillor in Ireland, Governor of the county of Waterford, and Colonel of the Waterford Militia.

It may be truly said that the subject of my notice maintained the character and feelings bequeathed to him by his great progenitor, Roger De la Poer, who accompanied Strongbow to Ireland, and there obtained for his services large territorial grants. A great and learned gentleman, writing of him, said: 
"It might be said without offence that there was not a man who did more valiant acts than Roger De la Poer; who, although he were young and beardless, yet, he showed himself a lusty, valiant, and courageous gentleman, and who grew unto such good credit, that he had the government of the country about Leighlin and also in Ossory, where he was traitorously killed; on whose slaughter a conspiracy was formed among the Irish to destroy the English, and many castles were destroyed." -Giraldus Cambrensis.

Again, Sir H. Sydney writes, 27 th February, 1575 :

"The day I departed from Waterford, I lodged that night at Curraghmore, the house that the Lord Power is Baron of; where I was so used and with such plenty and good order entertained (as adding to it the quiet of all the country adjoining, by the people called the Power Country, for that surname has been since the beginning of the Englishman's planting inhabitants there), it may well be compared with the best ordered county in the English PaLE."

Lord Waterford was educated at Eton and Christ Church, Oxford, and during his career there gained great notoriety for many wild, nay, reckless deedsindeed, if I were to write of all the extraordinary feats accomplished by him the record would fill more than one large volume; I will just give a few, hoping they may amuse. At Melton, he caused quite a sensation by a practical joke, costing him a good deal of money, which he played on an unsuspecting and eccentric gentleman who worshipped at the shrine of Esculapius in that locality. The doctor went some miles from the town to attend a patient, and before entering the house of the invalid, he gave the 
hack which he rode to a youth to hold. While he was performing his duty, Lord Waterford procured a quantity of aniseed, which he applied to the horse's heels. He had four couple of bloodhounds, and having given the physician some "law" when he was homeward bound, laid on the pack, which immediately set out in hot pursuit of the doctor and his steed. The horse naturally became frightened, and, despite the strenuous endeavours of his master, galloped several miles along the road and across an extensive common closely pursued by the bloodhounds. On another occasion he astonished the "Meltonians" by painting the toll-bar and other edifices; and in London he was continually getting irito "hot water" - wrenching off knockers, changing sign-boards, beating the watch, \&c., \&c., were pastimes in which he frequently indulged. At Southampton, too, he astonished the natives by one fine night painting the lions which ornamented the bar-gate blue and red.

Of the many stories told of his strange Etonian vagaries, the following is one: A great sensation was caused by the disappearance of the flogging-block from that chamber of horrors, the "library." The Marquis; with one or two companions who had just left Eton, entered the room (by walking along the stone ledge from one of the windows of the upper school), forced the door, and carried off their prize in triumph, in spite of the resistance of the college watchman. The block is still in existence at Curraghmore, I believe. The young nobleman was, indeed, the life and soul of the gay and thoughtless circle in which he moved. I need scarcely say that some of his most wonderful feats were accomplished in Ireland. 
On his way to the Curragh from Naas, he met a sweep, whom he knew to be a character and a famous boxer. His lordship, determined to have a pugilistic encounter, used certain abusive language calculated to "raise the dander" of the other, who shrewdly guessed the motive, and resented (or pretended to resent) being called "snow-ball." They immediately " tackled to work," and a merry " mill" ended by his lordship coming off decidedly second best. He gave the conquering hero a ten-pound note, and went on to the Curragh, bearing very distinct traces of his recent affray, and, on being interrogated by his friends as to the cause, told the story with great good humour, and said that he never had had such value for a "tenner" in his life.

A parson, who knew that the Marquis was charitable and generous in the extreme, was in the habit of soliciting alms from him very frequently. One day, the clergyman drove a new and excellently appointed trap to Curraghmore. Lord Waterford gave him $£ 5$, and was rather displeased at seeing that he was not quite satisfied, so he determined to be free from future solicitation in a quiet sort of way, and while the clergy. man was partaking of refreshment, the wild nobleman amused himself by whitewashing the trap, horse, and harness all over.

In 1840 , Lord Waterford established a small pack of staghounds at Melton, and always hunted them himself. A very memorable run is recorded of them, when, in the month of April, in the first year of their establishment, they hunted a stag a distance of thirtytwo miles. Some short time afterwards they took a hind in a cellar after a first-rate run, and the people 
in the neighbourhood declared that she knocked the cock out of a beer-barrel, and saved her life by "over liquoring" the huntsmen and hounds. One day, when they were running a drag, the inhabitants of a certain town were amazed to see them passing through the principal street, giving the melodious music for which they were remarkable. The huntsmen thought that the run was to have ended at his lordship's stables, but he gave the youth who ran the "herring" the "tip" to go on through the town.

There was an old coachman, who lived at the hotel in Naas, a noted pugilist, he was called "Red Ned." He was an extremely ill-tempered, cranky old chap, and Lord Waterford knew it. His lordship hired a carriage in Naas to bring him to the residence of an intimate friend, who resided a couple of miles from Naas, and "Red Ned" was the driver. He did not know Lord Waterford. Before they had gone very far, his lordship commenced to "chaff" Ned, telling him that he didn't know how to drive, that he would walk as fast as he was going, \&c. Ned became so enraged that at length he pulled up, and refused to drive any further, at the same time opening the carriage-door, and dragging Lord Waterford out. A boxing-match ensued between them, and after a sharp contest, "Red Ned" cried out: "Oh! stop, stop! I'm bate entirely. Oh, yer majesty! oh, my lord! I give in ; I'm bate! I fought scores of men, but never met my match afore. Let me off, my lord! your majesty, my lord! Oh! I know you now; yer either the devil or Lord Waterford; for the devil resave the one else could bate me."

While at college, Lord Waterford was "stroke" 
in many matches-indeed he was a capital oarsman. When he completed his university career, adopting the course then usually followed by youths of his rank, he set out for a lengthened tour. But absence from his native land does not appear to have cooled his rash and daring spirit, as he several times came under the notice of the authorities during his travels. When sojourning at Brussels, he made an attempt to carry off the well-known "Mannikin;" and while playing some harmless jokes on a Norwegian peasant girl, in her own country, he nearly met his death, as his skull was fractured by a blow from a policeman's truncheon. He visited the American continent, where he spent some time buffalo-hunting, and in Africa he destroyed many a "king of the forest," and he had a splendid lion in Curraghmore for some years, which he had brought home from that country.

The Marquis was staying at Liverpool during a race-week, about five-and-thirty years ago, and, after spending a very pleasant evening, he was returning to his hotel with a friend of mine, who, I am sorry to say, died some years ago (a genial, jovial, popular sportsman, and a noted steeplechase rider), when passing a tobacconist's, over the door of whose house hung a large metal man with a pipe in his mouth, my friend bet his lordship a "pony" that he would take down the statue. The wager was made, and the layer, who was a great athlete, jumped up, seized the "sign," and with great difficulty smashed the fastenings attached to it. The statue and the sportsinan, of course, both came down a "cropper;" the "sign" was uninjured, but its captor was severely shaken. The Marquis was pleased with the escapade, and having paid the 
bet, offered to give a pair of "ponies" for the metal man, but his friend declined the half century, procured a coffin, and brought the statue to Ireland, and for many years the trophy could be seen in a niche in a large tree in a demesne not a thousand miles from the Curragh.

When, at the close of the season $1838-9$, the Quorn Hounds were without a master, Lord Waterford was pressed to take them, but he declined. He was enamoured of hunting, and was a really good man to ride to hounds. He was "as bold as a lion," had a good seat, capital hands, but his head was not the best. He lacked those great essential requisites to a first-class race rider-patience and coolness-consequently he was inferior to those great artistes, Lords Macdonald and Eglinton, Sir Frederick Johnstone, Mr. Gilman, Captain Pettit, Captain Beecher, Mr. Purcell, Mr. Allen M'Donogh, Captain Ross, Dick Christian, Tom Olliver, and Mason, all of whom he opposed in many a great cross-country event. In the shires and wolds of England, over the oxers in Northamptonshire and Leicestershire, and the banks and walls in Tipperary, Waterford, Killenny, and Kildare, he led the van throughout many a quick "burst" and long-hunting run. Some of my readers, I am sure, have heard of the famous "Porch run," when Lord Lonsdale's huntsman, Lambert, killed his fox in the porch of Belvoir Castle, and declared that "I shall now die happy." Lord Waterford was one of a few who rode that famous chase from find to finish. He was one of the most prominent figures in Grant's celebrated picture, "The Melton Hunt," in a notice of which a writer said of Lord Waterford: "As a sports- 
man few of his experience rank higher. In the fieldas a steeplechase rider - a rider over the course-a yachter-in all manly exercises he has distinguished himself." In the coach-box he was quite at home, could handle the ribbons in the best style, and his team could scarcely be surpassed.

The first time his lordship donned the silk was in 1834, when he rode Lancet for the Aylesbury Steeplechase; but his debut was unsuccessful, as Lancet fell, and the celebrated Vivian won. After the race he matched his horse, Cock Robin, against the winner for $\ell^{1,000}$ aside, and a fortnight afterwards the match came off, four miles over the stiffest part of the Market Harborough country. Thousands came to see it, and Vivian got home in front of his opponent, owing to superior jockeyship, after a very close and severely contested race. In 1836 , his lordship again wore the "blue jacket and black cap," his well-known colours, and rode Yellow Dwarf for the Welter Stakes at Aylesbury, and was third to Saladin and Vivian. At Warwick he was equally unfortunate on the same horse. Yellow Dwarf was a hard-mouthed brute, but a fine fencer. His lordship heard that he was the best jumper in England, and sent word to his owner that he was anxious to buy him, and told him to send the horse to meet him at a certain covert in Leicestershire. The horse arrived while the field were standing in a lane beside a gorse which the hounds were drawing; there was a five-barred gate at the end of the lane. "Jump the horse over that gate," said Lord Waterford to the rider of Yellow Dwarf. "Oh, no, my lord, I will not." "Well, get down," said his lordship ; "you're afraid ; I'll ride him over it myself." 
He did so; the horse jumped it beautifully, and he bought him immediately at a high figure. At Dunchurch and Leamington, he again got situations on Cock Robin and Monarch; but his greatest performance in the pig-skin between the flags was accomplished at Eglinton, where he rode Blueskin one afternoon for three four-miles steeplechases, all of which he won, though he met fresh opponents in each contest, and carried a very heavy impost. Over this course and at Croxteth Park he rode his own horses, Tommy Tickle, Miss Chance, and Fop, with varying success. One of the most interesting dead-heats on record is that which his lordship rode on Columbine against Robin at Croxteth Park. On the same day he won the Melton Stakes on Red Wing, and the Free Handicap on Cardinal Puff. This horse he purchased from the Marquis of Westminster for $\mathbf{1}, 200$ guineas. In 1840 , he won three races in two days at Croxteth Park, viz., the Hunters' Stakes on Redwing, Amdelly Stakes on Confusion, and the Rosslyn Handicap on Redwing also. In I $84 \mathrm{I}$, the Marquis's colours were, for the first time, seen on an Irish race-course, when they were borne by a grey horse named Hackfall for the Stewards' Stakes at the Curragh April Meeting. He was not placed, and on the following day they were again carried unsuccessfully by Cardinal Puff. The first victory he achieved in this country was at the June Meeting following, when Redwing, a chestnut six-year-old, son of Skylark, created a surprise by defeating his quandom stable companion, Falcon, and three others for a small sweepstakes. On the next day, in a match for 100 sovs., r 2 st. $31 \mathrm{lb}$. each, over Connolly's mile, Lord Howth's Augean, an aged 
son of Sir Hercules, with 3 and 4 to 1 on him, easily defeated Lord Waterford's Hackfall, and Redwing suffered a couple of defeats also during the week. At Kilkenny, in October, Manilla was twice beaten, and Blueskin won a hurdle race, but was not placed for another. At Tramore, in the same month, his lordship steered Manilla to victory for a minor stake over timber; and Ballysax, a horse he bought from a relative of the author at the end of the year, also gained a few brackets.

In 1842 , the first race he won was with Redwing, who beat Mr. Watts's Forester for the Wellingtons at the Curragh April Meeting, and on the following day Redwing walked over for the Challenge of the Wellingtons. At this time Columbine, Blueskin, Usurper, Redwing, Firefly, Ballysax, Black Dwarf, Fairy (by Rockingham, out of Cronstadt), Conrad, Manilla, and Kilmoylan, comprised Lord Henry's racing stud; but none of them except Redwing, Firefly, and Fairy were very good, the last-named being, indeed, a speedy, neat filly.

In 1843, "Larry" Byrne, who had been for some years trainer to Mr. Ferguson, who resided at Rossmore Lodge, resigned the situation, and became manager of Lord Waterford's stud. Fourteen horses carried his lordship's colours that year, but their owner had not by any means a "rosey" time of it. Henry, a neat chestnut four-year-old, with an erratic disposition, won six races value 340 sovs. and a silver cup, Tearing Thief won four small stakes, and Fairy secured a couple of "centuries" at the Curragh.

In the following year, the familiar jacket: was first carried by Blueskin, in a race which will long be remembered by those who sa'w it. It was the Munster 
National Steeplechase of fifteen sovs. each, 100 added, weight for age, three miles, and nine ran. Before they had gone far, a speedy mare named The Fawn (belonging to Mr. Power) was killed, and ere half the journey had been traversed the contest was confined to a quartette of good horses and good men-Mr. Colgan on Erin, Blueskin ridden by his trainer, L. Byrne, Fra Diavolo steered by the famous John Dennis (the ever-to-be-lamented master of the "Blazers"), and Mr. Mat Dunne of Punchestown (a true and popular sportsman) on the game Fanny Elssler-a daughter of Smallhopes. It was a terrible struggle, but Fanny was first, after a great finish with Fra Diavolo. The winner won many races, and only that Erunette was her superior, more than two Kilrue Cups would have been placed to her owner's credit. The mare was at one time the property of Mr. IV. M'Grane, who now resides at Montpelier-hill. He used to ride her as a hack, never thinking that she was such a sterling bit of goods, although he was then, as now, an excellent judge of hunters, racers, and chasers. He often rode to his farm, situate about seven miles from Dublin, and one day while he was there, the Kildare Hounds happened to pass by, on their way to draw a covert in the neighbourhood, and Mr. MG Grane joined the hunt. although Fanny Elssler was not all up to his weight nor in very good trim. A fox was found, and a splendid run over the "cream" of Kildare ensued. Mr. $M$ 'Grane and the late Lord Howth, who, I need scarcely add, was a "clinker," cut down a large field, and Mr. Dunne having heard of the performance, Fanny Elssler soon afterwards became his property. That year Henry won a plate of 46 sors., and also a 
cup at Kilkenny. Another of the stud, Condor, a good horse, by Economist, won the Wellingtons of 105 sovs. in April, and next day beat a field of eight good horses for Her Majesty's Plate. This horse's third appearance that year was his last on a race-course, as he broke down when running for the Kirwans of 50 sovs. each at the Curragh June Meeting. The chaser Blueskin secured the New Melton Stakes at Cahir of 15 sovs. each, 100 added, but had Brunette not fallen she would have made him play "second fiddle" to her; a few days afterwards he gained another "bracket" by winning a sweepstakes at Dungarvan.

In 1845 , the Marquis had sixteen horses in training, including King Dan, a beautiful son of Plilip the First, which he purchased for a very long price from Mr. George Watts, and was about the best horse that performed in Ireland during that year. At the Curragh June Meeting he won Her Majesty's Plate of $1 \mathrm{co}$ gs., four miles, beating Ironmould, Colleen Dhas, Fireaway Helpmate, Beatrice, and Highwayman. On Tuesday of the following October Meeting he won the Kirwan Stakes of 50 sovs. each, h. ft., beating Switcher and Star of Erin, twelve others paying forfeit. On the following Thursday, he won the Cesarewitch Stakes with Ioo sovs. added, about two and a quarter miles, beating Coranna (winner of the Newmarket Cesarewitch Stakes and Chester Cup, the former comprising a field of twenty-five horses and the latter thirty-three, including The Baron, winner of the Doncaster St. Leger) and three others. Same day he won the Challenge of the Kirwan Stakes of IoO sovs., beating Switcher. On Friday, he ran a beautiful race for the Gold Whip, four miles, being only defeated by a 
nose, beating Mr. Salvan's celebrated mare Alice Hawthorn, Beatrice, and Warp. Lord Waterford won a sweepstakes at the Curragh April Meeting on his own horse, The Robber, defeating three others, and at the following re-union there steered a second of his racers to victory for the Corinthians, Mr. Moore on Firefly, Mr. Allen M·Donogh on Mordaunt, and Olliver, ridden by Mr. Kennedy, finishing behind him. The Corinthian riders of those days were, indeed, sportsmen in the truest sense of the word-excellent horsemen and "pillars" of the turf. On reference to the "Calendar," I find that for the Corinthians at the "Newmarket of Ireland" in September, I 845, Lord Waterford's Arcanus, ridden by Mr. G. H. Moore, won. His Lordship was second on his own horse, Smike, Count Batthyany third on Paragon ; Lad of the Vale (Mr. Kennedy), Woodranger (Mr. Nunn), Switcher (Lord Howth), also ran, but were not placed. Before the end of the year thirteen races were won by the Curraghmore stud-Henry won four, value 165 sovs.; Arcanus two, value 130 sovs.; and Smike and Firefly adding considerably to their owner's exchequer.

In $\mathrm{I} 846$, fourteen horses comprised the racing stud, and the legitimate campaign was opened at the Curragh, on the 21 st of April, with a match of 100 sovs., a mile and a half, I sst each, which resulted in the defeat of Mr. Irwin's Whack, on whom 6 to 4 was laid, by Lord Waterford's The Robber; however, the stable was in very bad form throughout the year, as in Ireland only five races, value $£ 407$, were won by its representatives; but King Dan won the Blythwood Free Handicap of 95 sovs. at Eglinton Park, and at 
the same meeting he brought his racing career-a very brilliant one it was-to an end, and won a handicap of 40 sovs.

The years 1847 and 1848 were unlucky ones so far as Lord Waterford's fortune on the turf was concerned. At the end of 1848 , Byrne resigned, and, purchasing Mountjoy Lodge, set up as a public trainer. His Lordship's horses were then placed under the care of an adept at the business, Robert I'Anson.

With the change of trainers there came a turn of luck, and in 1849, twelve winners hailed from the stable. Queen Margaret, the dam of Lord Drogheda's Clarence, Mons Meg, Queencake, King Rene, \&c., won the Angleseys, and proved herself to be the best animal of her year, with the exception, perhaps, of Mr. Watt's Marchioness D'Eu. Her stable companion of the same age, Robert (brother to Bon Mot), was also a speedy colt. Brother to Rat-trap, Cracow, Postilion, Modesty, Sir John, and others, carried " Lord Henry's" colours first past the post during that year, six of Her Majesty's Plates falling to them. The form shown by Sir John, a fine cut of a chaser by Windfall, slam by Middleton, at Liverpool, in November, was excellent, when seventeen were weighed out for the Grand Autumn Free Handicap, value 3,30 sovs., and some of the best chasers in the world were amongst them, and ridden by the most accomplished horsemen. The distance was four miles, over what was truly described as "a fair hunting country." J. Mason was on Proceed, favourite at 3 to I; the second in demand was that great four-year-old, Vain Hope, and at sixes Sir John was third best in the market. Lord Strathmore piloted his own horse, The Doctor, 
and an Irishman, Charlie Canavan, father of David and IVillie, who have been so fortunate during the last few years here in Ireland, was on Wolverhampton. It was a fine race between Sir John, who was steered in artistic style by J. Ryan, Vain Hope, The Doctor, and Proceed. Sir John and Vain Hope cleared the last flight of hurdles together, but the Irish horse, gradually forging ahead, won a well-contested race by a couple of lengths.

The year following two celebrated horses were added to the string--Lord George and Duc-an-Dhurrasand during the season they scored many wins. The performance of the latter was, indeed, brilliant; few better horses ever looked through a bridle. He was by Molyneux, his dam Calamity, by Vampire. Molyneux was own brother to Bloomsbury, St. Giles, Vacuna and Scroggins. He was not a prolific sire, but got a few first-class horses. St. Giles won the Epsom Derby in 1852 , and Bloomsbury the same race in 1859 . Duc-an-Dhurras was a brown horse, 15-3 high, a model, perfect in symmetry, up to big weight, and won no less than 21 races. In $185^{\circ}$, at the Curragh April Meeting, carrying 1 ist. 7 lb., he won a stake of Io sovs., h. ft., 20 sovs. added; at the same meeting he won, at two heats, the Corinthian Stakes of 10 sovs. each, h. ft., 25 sovs. added, carrying 12st. 9lb.; in the June Meeting he won, at four heats (one being a dead one), carrying I Ist. 6lb., the Scurry Corinthian Stakes of 5 sovs. each, 25 sovs. added; he won the Metropolitan Stakes at the Phœnix Park of 10 sovs. each, h. ft.,. 100 sovs. added, carrying 7st. I I lb. ; at the Curragh September Meeting, same year, he won the Wellington Stakes of 30 sovs. each, h. ft.; carrying 7 st. 7 lb.; the 
next day, carrying 9st. 5lb., he won the Second-class of the Railway Stakes of 15 sovs. each, 5 sovs. ft., with roo sovs. added. Lord Waterford was near winning the Liverpool Grand National that year, with Sir John, who started second favourite -7 to 1 was the priceI Ist. 8lb., and "Johnny" Ryan was on his back. Two-and-thirty candidates contended for Grand $\mathrm{Na-}$ tional honours and $95^{\circ}$ sovs. At 5 to I Peter Simple was favourite, although he carried top-weight (I 2st. 2lb.) His old jockey, Cunningham, rode him, and he won so cleverly the previous year, when he defeated a field of three-and-twenty, that his party were extremely sanguine. Poor Wynne rode the Knight of Gwynne; his countryman, Mr. Abbot, was on the Irish horse Farnham, "Johnnie" Hanlon steered The Iron Duke, and a "gallant" grey, The Oaks, did battle for her owner; Mr. J. G. Murphy, of the Grange, Summerhill, Canavan rode her; and the glory of " ould" Ireland, Abd-el-Kader by Ishmael, out of English Lass (9st. I 2lb.), was ridden by Green, and was not backed for a shilling in the ring before the race, but on entering the course the second time a few who had the misfortune to mistake him for Little Fanny, laid I oo's to 3, 4, and 5 against him. One of the "Irish brigade," as is almost invariably the case in this race, caused a scrimmage at the very first fence, as The Oaks cannoned against Peter Simple, and, interfering with him, placed herself hors de combat. Abd-el-Kader made the pace a "cracker" along by the canal, and held a long lead entering the straight. Before the final flight of hurdles was reached, however, Sir John had almost overhauled him; the leader hit the last obstacle very hard, still Green kept him on 
his legs, but the hurdle, pivoting on its central fastenings, caught Sir John as he leaped it, and nearly knocked him over, while The Knight of Gwynne, who was next, landed safe. Opposite the stand Wynne came with a well-timed rush, but could not catch Mr. Osborne's game Ishmaelite, who won a well-contested race by three parts of a length for a good sportsman, who received a regular ovation when his little horse returned to the scales; Sir John was a good third. The first round up to the water-jump was accomplished in 4 mins. 28 secs., and the whole distance in 9 mins. $57 \frac{1}{2}$ secs.

The Marquis's horses performed very successfully indeed in $185 \mathrm{I}$. The Marquis of Carabas won three races value 82 sovs., Captain three, value $\ell^{2} 31$; Duc. an-Dhurras won 160 sovs. ; Kick-up-the-Dust, a very good filly, then a three-year-old, won $£ 515$, and five races; Lancaster, Hero, and others, all brought "grist to the mill." In England, too, the Marquis fared well in the racing world, as at Chester Kick-upthe-Dust won the Grosvenor Stakes and Queen's Plate, and Roller the Citizens' Guineas. But the followers of the stable "dashed it down" on Duc-an-Dhurras for the Chester Cup, and he ran very badly. The horse ran well for the Goodwood Stakes subsequently, and Lord George did well at Brighton, where he won two stakes cleverly at the same meeting. The equivocal performance, however, of Duc-an-Dhurras there caused great surprise. Robinson, who had won many races for his Lordship, rode the horse in both races, and, I may observe, that at Brighton he lost one of his stirrupleathers. After the race Lord Waterford dismissed Robinson, and his trainer, I'Anson, deeming the 
decision a hard one, retired from his service, and was replaced by Richard Price.

That same year Sir John ran for the "Grand National," carrying top weight (11st. r 2lb.) Twenty-one started. Rat-trap, who was ridden by Jem Mason, was favourite at 6 to 1 , and at a point more Lord Waterford's horse and Abd-el-Kader were backed. The winner of the previous year carried 6lb. more than he did on the former occasion, and was ridden by $\mathrm{Mr}$. Tom Abbott, the justly celebrated Irish amateur. Ryan was again on Sir John. The winner of the Kilrue Cup that year, Carrig, also ran, and Debeau rode him. At the third fence the favourite refused. During the early part of the contest Tom Olliver, on Tipperary Boy, made the pace good; Sir John, Peter Simple, and Maria Day, lying close up, headed the others. At the turn coming into the straight, Tipperary Boy, having shot his bolt, beat a hasty retreat, as did Half-and-Half, who was going well up to this. Maria Day held a clear lead at the last obstacle, but hitting the hurdle very hard, she fell on to her head, and, although recovered in masterly style by Frisby, Abd-el-Kader caught her before she was in her stride, and Sir John was at her quarters. Long before the stand was reached the whips were singing off the trio, and none who saw that grand and prolonged struggle can ever forget it. Shouts of "Abd-el-Kader wins! the Marquis has it ;" and cheers for Maria Day made the "welkin" ring as, locked together, they struggled up the run home. The light-blue jacket was the first colour lowered, as, before they came to the stand, Sir John was "done," and ultimately, after as fine an exhibition of horsemanship as was ever displayed at 
Aintree, Mr. Abbott grot the gallant Arab Chief home in front, landing as game a horse as ever was girthed a winner by a head of a second "Liverpool." Mr. Osborne was most anxious that Mr. Abbott should ride the horse, and in order to get to the weight he had to waste a great deal, but he was by no means fond of adopting the "banting system." Early in the morning of the day the race was run Mr. Abbott was no less than 6lb. over weight. An intimate friend of his, an Irish gentleman, who is still "to the fore," begged of him to go to Mr. Osborne and tell him that he could not ride Iost. $4 \mathrm{lb}$; ; he naturally believed that it was quite impossible for a man to reduce so much in so short a time, but he would not; he was determined to ride, so he put on all the "sweaters" he could carry, and walked for hours, keeping them on until he was obliged to don the silk. He was, of course, very weak, and, as is often the case, the long and severe exertion during the race reduced him considerably. When he got into the scales, to his great astonishment it was found that he was light-just merely so. He was in it for some seconds, and it seemed he would scarcely "draw it." It may be truly said that thousands were in the balance. An Irishman -I will not give his name, as he is still living at the Curragh-seeing the state of affairs, unperceived by the clerk of the scales, just put his toe on the weighing machine, turning it in favour of Mr. Abbott. In the meantime, Frisby, who, as I have already stated, rode Maria Day, hearing a rumour that his conqueror was light, came rushing up, and met him just as he had got out of the scales. He immediately requested him to get in again. Mr. Abbott, not knowing what his 
countryman had done, was naturally disposed to comply with the request, and was about to do so when his "friend indeed" again came to the rescue, and said to him: "Come on out of that, Mr. Tom, do you want to insult the weigh-master by making him weigh you twice?" The trick was successful, and the Irishmen went their way rejoicing. The same month, at the Warwick and Leamington Meeting, Lord George, in the hands of Captain Dyson, won the Hunt Cup, beating a large field.

At the end of the year, Lord Waterford purchased Redmond O'Hanlon from Mr. Dunne of Ballymanus for $\ell^{1,000}$, and The Marquis from Mr. Watts for a very big price; and in the year following he had as good a stud of racers and steeplechasers as any man in Europe. Lord George, Duc-an-Dhurras, The Marquis, Redmond O'Hanlon, Roller, Cock-crow, Augustine, Lancaster, Sharavogue, Ranger, Eleanor, Celt, Kick-up-the-Dust, Hero, Warner, all won races for him-33 in Ireland, their value amounting to $£^{2,680}$ IOs., and three on the other side of the Channel, where Lancaster won the Chesterfield Stakes, Sharavogue the Citizens' Guineas, and The Marquis the Dee Stand Cup-all at Chester. That year, at Epsom, the Marquis bought Barbarian for $6 \mathrm{r}, 000$ immediately after his running second for the Derby, hoping to win the Royal Hunt Cup at Ascot with him, but the horse unfortunately broke down during that race.

In 1853 the stable was successful, eighteen races, amounting to $£ \mathrm{I}, 664 \mathrm{I}$ os., being the result of the performance. The next year there came a great change for the worse-Lobster, Marquis, Lambay, Warner, a 
two-year-old, by Tearaway, out of Gramachree, and April Fool were the only winners; eight races fell to them, but the sum total amounted only to $£ 37 \mathrm{I}$. With a change of the year fortune became more favourable, and $£ 1,288$ of Irish money fell to his Lordship, Warner, April Fool, and Augustine being the principal contributors.

In 1856 , the Marquis's stable was in singularly bad " form," although Cheerful Horn (brother to Horn of Chase) won eight races, but they were worth only $£ 340$. None of his stable companions won any important race. In 1857 , no better came; quite the contrary, although Meigh-Dair was added to the stable. But in the following racing season there was a great change for the better, Lord WVaterford's horses winning nearly all the principal races in Ireland. I should have remarked that Weatherall, who had been private trainer for some years to Mr. Worthington, succeeded Price in the management of the stud at the beginning of I 859 , and several "clinkers" joined the teamVixen, Daisy King, Geology, and others, all of them performed brilliantly, and at the end of the year his Lordship's name headed the list of winning owners in Ireland with $£^{2,344}$ to his credit. The last horse that ever carried Lord Waterford's "cap and jacket" was Ace of Hearts, when he was beaten for the Liverpool Grand National, a few weeks before his Lordship's death.

When Mr. Hodgson gave up the mastership of the Quorn Hunt, the Marquis purchased several of his hunters and twenty couple of hounds at his sale. He brought them with him to Ireland, and he may be called the founder of the "Curraghmore," of which 
pack he was master for nineteen years and six months, his reign only terminating at his death. On the day he died, the hounds met at Castlemorris, county Kilkenny, about four miles from Carrick-on. Suir. It was late in the afternoon when a fox was found in Corbally covert. Lord Waterford was riding a hunter, which he purchased a year before from the then master of the Neath Hounds. When the hounds came to the road, near Mountain Grove, John Ryan, the whip, and the Marquis were in front of the small field of pursuers. They came to a wall, about $2 \frac{1}{2} \mathrm{ft}$. high; Ryan got over safe, but his master's horse landed with his fore-feet on some stones, and fell on to his head and knees. His rider clung on to his neck for a few moments, and then fell off. The fall was apparently harmless, and Ryan was amazed when he saw that his Lordship never moved. In a minute he was at his side, and, assisted by a groom named Thompson, lifted up the dying man. Dr. O'Ryan soon joined them, but the pcor Marquis was no more. Death was almost instantaneous; his neck was broken, he never spokejust sighed, and expired.

Great, indeed, was the grief throughout Ireland when the news became widely known. Thousands mourned his loss. People of all classes loved the gay, high spirited, generous nobleman. He was a model landlord, kind to a fault, sincere, genial, and jovial. He was a nobleman in more than one sense of the word. His funeral was one of the largest ever seen in Ireland. Vast numbers joined the mournful procession to pay a tribute of respect to him who was an example worthy the imitation of his class. The poor 
of his native county lost in him a true benefactor. It may be truly said :

"The sower stayed his hands to hear; The honest ' grey-coat' sighed, The world appeared so sad and drear That Tuesday when he died."

The Irish turf has never since been patronised by so staunch a supporter; no less than 152 nominations in Ireland and 9 in England, including five for the Derby and four for the Oaks, were rendered void by his death. He had first-class stock of every description, and excellent cattle and sheep. At a sale of his hunters, held at Curraghmore in October, 1858 , the lots sold realised $£ 3,100$, and those bought in were knocked down for $£ 8,200$. At the sale of his thoroughbreds, which took place a few months after his death, gerat prices were given for some. On the whole, it was a very dear auction, buyers from all parts of Ireland, as well as many from England and the Continent attending. 33 brood mares, 14 foals, 3 stallions, 14 horses in training, 18 two-year-olds, 23 yearlings, 33 hunters, and 3 carriage horses came to the hammer. The 33 mares and 14 foals averaged $£ 907 \mathrm{~s}$. Several famous stud matrons and good public performers were amongst them. The Deformed, covered by Gemmadi-Vergy, fell to the bid of Mr. George Bryan, $£ 260$ being the price. Princess, covered by Gemma-diVergy, fell to Mr. Hamilton's bil of 50 sovs. This mare was the dam of Colleen Rhue and other good racers. Colleen Rhue bred Prince, Norma, Kyrle Daly, Naid of Athens-all good-'uns. Lord Drogheda purchased Queen Margaret for \&,100. Sarah Ellis, 
with filly foal at foot, Mr. Longfield paid a "century" for. The well-known brood mare, Juanita Perez, covered by Gemma-di-Vergy, was sold to Mr. Weatherby for $£ 35^{\circ}$. Peri was the highest-priced mare sold, she, with filly by Hobbie Noble, being bought by Mr. George Bryan of Jenkinstown for 6380. She was stinted by Gemma-di-Vergy. Mr. Longfield purchased Magnet for $£^{8} 5$. The sires were Gemma-di-Vergy, The Marquis, and Royal George, who was bought in for $£_{509}$. Mr. Langan of Bellewstown gave $£ 220$ for The Marquis. Mr. Hamilton, a Queen's County gentleman, purchased

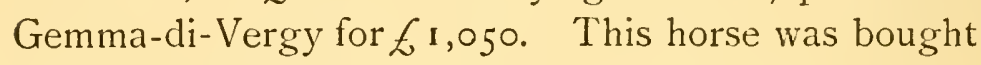
by Lord Waterford a month or two before his death for $8 \mathrm{co}$ gs. The fourteen race-horses realised $£^{2, \mathrm{I} 33}$ :-Daisy King, 4 yrs., Mr. Powell, $£^{280}$; Bumble Bee, 3 yrs., Captain Beresford, \&550; Hibernia, 3 yrs. (the dam of Ould Ireland, Pride of Kildare, \&c.) Mr. E. J. Irwin, $£ 70$; Ace of Hearts, 5 yrs., Mr. Powell, $£ 315$.

The young horses sold well, as alsn the hunters. May-Boy was bought by Mr. Sewell for $91 \mathrm{gs}$. , and the Marquis of Drogheda gave $£ 220$ for Oberon, he won some steeplechases for him soon afterwards. The twenty-nine horses brought $£ 3,358$. The largest purchaser at the sale was Mr. Hamilton, who expended some thousands. It was proved subsequently that the unfortunate gentleman was insane, and, of course, he was not obliged to take the horses. They were resold at Sewell's, and brought about the same money as he bought them for, Mr. John Cassidy, of James'sstreet, Dublin, purchasing Gemma-di-Vergy for Sir Lydston Newman. Mr. Lyons of Moyanna. Queen's 
County, purchased Princess, and many a time since has the "yellow jacket," his well-known colours, been successfully carried by her descendants.

The Marquis of Waterford, I should add, married, in 1842 , the second daughter of the late Lord Stuart de Rothesay. The ceremony took place in the Chapel Royal. To say that she was one of the most beautiful women of her day is to say the least in her praise. She was, and is, kind, thoughtful, charitable, and esteemed by all.

After his marriage, the Marquis was no longer wild. He never at any time made inroads on his fortune, and although he spent a great deal of money, he never forgot that property has its duties as well as its rights. 


\section{CHAPTER XXI.}

THE CORINTHIAN CUP PICTURE, PUNCHESTOWN, 1854.

Peritaps the most successful of the many splendid productions of the pencil of that talented artist, Michael Angelo Hayes, is the print which hangs within the homes of nearly all distinguished Irish sportsmen, "The Corinthian Cup, Punchestown, i 854." I shall now record some of the feats in the saddle, and give a brief memoir of the subjects of Mr. Hayes's portraiture. Many of them have "gone over to the majority," but the fame of these "light of other days " will survive some generations of sportsmen.

On the left hand side of the picture is an admirable likeness of the late Lord Clonmel.

Fohn Henry Scott, 4th Earl of Clonmell, was born 4th January, 1817, and married, 1838, Hon. Anne de Burgh, eldest daughter of the second Lord Downes, and they were said to be the handsomest couple in the Irish peerage.

His Lordship, as the reader will see on reference to the first chapter, was Master of the Kildare Hounds for some years, and was one of the most popular of the many favourites who have held that post. He was known as a kind-hearted landlord, remarkable for his genuine wit and cheery humour, and was extremely 
fond of horses and hounds, and always kept a stud of such horses that I do not exaggerate when I say that in the saddle his Lordship generally "clasped perfection." The carriage department in Bishop's Court was most carefully looked after, and the harness-horses were models of their kind, so that his "drives" were the "pink of perfection." Early in life his Lordship was an excellent "whip," but of late years he handled only single "ribbons." About the time the picture was taken, he had given up driving his own team, but was to be seen at each annual gathering at glorious Punchestown, in the box seat; his usual overcoat of splendid proportions, made of a white material, with red and black cross-bars (horse-cloth pattern), being the centre of a tumultuous cheering crowd, from the. "gap" to the "yard." His love of sport, and the "Stunner Tartan" were, however, the only points of resemblance between Lords Clonmel and "Scamperdale." Old habitués of Punchestown will remember Lord Clonmel, as, with long thong whip in hand, dressed in the scarlet uniform of the Kildare Hunt Club, and mounted on his favourite white horse, he cantered up and down the rails, cheerily rating the rustics, with whom, as with those of his own rank, he was an especial favourite. One day, when "clearing" the course, a young gentleman, now a popular medical man in the county, did not get out of his Lordship's way quickly enough. His horse, a fractious four-year-old, objected to pass the crowd at either the stand or the run-in end. "Begad, M _- I must make him move," said his Lordship. Crack goes his double thong, whirr goes the four-year-old. Round he comes with a snort, then a plunge, and straight 
away cannons against the white hunter under double thong. "Hullo! you young ruffian, I'll make you leave this." And away goes the four-year-old and his young master, pursued by the white horse and his noble one. John Gilpin's ride was not funnier. The crowd halloed, the stand encouraged. "Go it, you devil ", "at him, Clonmel ;" "well done, young ster ;" " now, your Lordship ;" "hurroo !" and so on, till the "young un" cleared the drop fence past the stand, leaving his rider's hat, now encircled by the dread "double thong," as spolia opina in the hands of the Lord of Bishop's Court. Lord Clonmel, from the time of his retirement from the army, which took place after a few years' service, generally resided in Ireland.

The present Earl was born on 2nd of March, 1838 , and succeeded to the title and estates on the death of his father, which occurred in February, 1866. He is unmarried. When Lord Earlsfort, he served for some years in the Life Guards. He very much resembles his father in person and character, and is a good landlord, large employer, liberal paymaster, and subscriber to the Kildare and Tipperary Foxhounds. He is very fond of hunting; and his stables are tenanted by hunters as good and good-looking as money and sound judgment can procure. Like his father, too, he has a decided penchant for "suited" harness-horses. His Lordship never had racers, but he is fond of the pastime. $\mathrm{He}$ attends the principal English and Irish flat and steeplechase meetings, and is a member of the Irish National Hunt Steeplechase Committee. He deserves the gratitude of the Kildare tenant farmers, for his liberality in adding 25 sovs. annually to the Farmers' Race at Punchestown. I should add that he is an Irish repre- 
sentative peer. However, he is more frequently to be seen where sportsmen most do congregate than in the "House ;" and if he is a conservative in politics, he is a decided liberal in hospitality.

Next to that of Lord Clonmel is the portrait of the late Lord Cloncurry, who was his intimate friend and neighbour. He was 3 rd Baron, and married the only daughter of the late John Kirwan, D.L., of Castle Hackett, County Galway. His Lordship, who was a first. rate rider to hounds, died in 1869 , and was succeeded by his son, Valentine Lawless, the present head of the house, who is not such a welter weight as his father was, but an ardent fox-hunter and a remarkably good horseman. He rode his own mare for the Kildare Welter Sportman's race, in $\mathbf{1} 877$, in a manner which gained for him the highest praise; and he certainly won by superior horsemanship. But it is as lover of the "gentle craft" and good shot that his Lordship ranks highest as a sportsman. He is one of the best rifle shots and most expert anglers in the kingdom. His brother, Major the Hon. Edward Lawless, served in the Rifle Brigade, and an officer of the Kildare Rifles. He is an ardent devotee of hunting, and is one of the very best men to hounds in his native county. $\mathrm{He}$ is a lover of cricket, too, but he shines to more advantage on the moor or the mountain, as few better game shots ever pulled a trigger.

On looking at the work of art under notice, his many friends must have at once recognised Sir Philip Crampton, on "Poteen." Assuredly the popular Baronet was pre-eminently entitled to the distinction of a prominent place in such a "gallery" of sportsmen. He was, indeed, a sportsman keen, the wittiest of wits; 
and bon vivant noctes ambrosiance were they, at which were found such men as his pupil, Charley Lever, Mr. Le Fanu, "Beauty Addison," Lord Allen, and his genial self.

The name of Captain Charles Varburton, as a matter of course, "crops up" frequently in this volume. He was one of those who ably seconcled the efforts of Lords Drogheda and St. Lawrence to make "Princely Punchestown" what it is ; and he is still an acting and industrious member of the executive. He was one of the best steeplechase riders of his time. In saying this I am paying him a high compliment, for besides the many grand horsemen included in this famous picture, such men as Mr. A. Knox, Mr. Quinn, Mr. Charley Lockwood, Captain Townly, Dixon and Severne, Mr. St. John Brereton, Major Bell, Mr. Tom Kennedy, Mr. J. Kelly, Mr. Tom Abbott, Captains Prettyman and Bernard, and many other great amateurs were in their "hey-day" of renown. I should add Lord Poulett too. He was then a captain, and, while stationed in Ireland, won many races; on his own horse, Smuggler Bill, he frequently gained "brackets." His horses were trained by Will Conlon of the Curragh, who accompanied his Lordship to the northwestern province of India, where he was stationed for eleven months, during which time he accomplished the wonderful feat of winning forty-three races out of fifty-seven mounts.

One of the most distinguished of the many celebrities in this engraving is Sir George Wombwell, Bart., who, in 1854 , rode Slinge for the "Cup." He was then on the Staff. In the Crimea he gained the reputation of being one of the bravest officers on Lord 
Cardigan's staff. At the battle of Balaclava he gained enviable notoriety. During that memorable battle he had two horses killed under him within a quarter of an hour. TVe have often heard it said that nothing befits a man more for fatigues of war than the training and endurance gained by the participation in the pleasures of the field. There was no more ardent advocate of "The Sport of Kings" than this worthy Baronet; and his activity and horsemanship was, indeed, an acquisition to him in the campaign; and but for his prowess in this respect, he would have been killed in the Balaclava engagement. He was taken prisoner by the Cossacks; but ere long, a loose horse came galloping up to where he was standing, and he vaulted into the saddle, and made his escape.

My readers may remember that Sir George was in the ferry-boat which upset crossing the River Ure, when six good sportsmen lost their lives. More than one of them was a good swimmer; but Sir George could not swim at all, yet he escaped. He appears to have a charmed life. Sir George Vombwell is one of the strongest supporters of hunting in England at present, but cannot be styled a racing man.

On the right sicle of the picture is the late Mr. Sam Reynell, who died recently. There were few men more highly esteemed than this Nestor of the chase and noted Nimrod. I have already written of him in my notice of the Meath Hounds. That history was penned before his death. Ile very kindly supplied me with much of the information it contains. He went to some trouble in orcler to do so; as he saicl to me at the time: "I am crer anxious to lend a helping hand 
to a sportsman." He died very suddenly; and very soon after I last heard from him he was on his deathbed. Take him for all and all, his like we seldom see. He was fond of steeplechasing, and had a few horses, but never was very fortunate on the turf.

Any interest which I may have stirred up in my references to those who were the subjects of Mr. Hayes' portraiture would be very greatly supplemented were the names of some Irish sportsmen not represented there dealt with, and amongst them some of Captain Richard Bernard's relatives would be entitled to a foremost place. I use the centurion title because it was that borne by the present Chamberlain, Deputy Ranger, and Colonel of the King's County Rifles, at the time when the picture was painted. It was hereditary in the Bernard family to ride, especially in the generation of which Richard Wellesly Bernard made one. His mother was a Hutchinson, of the Donaughmore family, and aunt to the Hon. W. Hutchinson. His father, of Castle Bernard, in the King's County, and his father before him, were as noted in the saddle as for their banking enterprise. It is not wonderful, therefore, that Colonel Richard Bernard, like his brothers Scrope and Thomas, attained a reputation as a dashing horseman.

As a resident landlord, discharging all the duties attaching to a country gentleman's position, Colonel Thomas Bernard has acquired a praise more valuable than that which many years ago, before he lost his hand by a gun accident when grouse-shooting, had been accorded him for his exploits as a game shot, in the saddle and on the coach-box. His other brother 
did not live long enough to gain the place in the annals of Irish sport which his accomplishments would have entitled him to. It is not, however, my office now to speak of them or their conquests. In my chronicle of sport I should rather fill up some pages in recounting the deeds of the youngest brother of the three; and if to "witch the world with feats of noble horsemanship," be worthy of ambition to Colonel R. Bernard, then belongs the crown of conquest. Early in life he entered the Austrian service, but long prior to the Crimean war, through which he served as a volunteer, the greater sporting attributes of his own land recalled him to Ireland. During the years which have intervened, few names have been so constantly and so creditably as his on the lips of hunting and racing men on this side of the Channel. Elsewhere I have alluded to his connection with the "old garrison" and Kilkenny Hounds, and it is now only possible for me to assure my readers that he was a horseman of undaunted pluck and judgment, with a perfect knowledge of pace, exquisite hands and seat, great strength, and a coolness in difficulties and in finishing, which gained for him the credit of more "head" than almost any of his Corinthian opponents. Such qualities of a successful sportsman were backed up by a thousand others which only belong to the character of a most amiable and kindly-hearted man, and perfect gentlemen, have gained for Colonel "Dick" Bernard an army of admirers and well-wishers, amongst whom the writer hopes he may be permitted to enrol himself.

The chapters on the Ward Union Hounds and the "Killiennies" were printed, and this brief reference I 
have made to Colonel Bernard was written before his death. I need not divell on the circumstances attending his very sudden demise; they are fresh in the memory of his friends. At the inquest, a man looking, for the last time, on the face of Colonel Bernard, said: "Good-bye, poor Colonel Bernard; waistcoat never buttoned over a braver or kinder heart than yours." All who knew him would say the same.

Lord Waterford has been so often written of in other chapters, that a mention of him here would be mere repetition. But his name brings me back to his contemporary and opponent on so many a well-fought field, the late "Lord Howth." During the fifty-two years which this nobleman was head of the house of St. Lawrence, no name loomed bigger in the view of his countrymen than his. His hunting career has been elsewhere touched on, to do it justice were a difficult task; and a brief, and, perhaps, imperfect reference to his doings on the turf, is all that is open to me now.

Lord Howth, Viscount St. Lawrence, Vice-Admiral of Leinster, \&c., born I 803 , succeeded to the title as 3rd Earl, i 822. The earldom of Howth is of comparatively modern date-1767. The barony is very ancient, as his Lordship's ancestor, Sir Amory Tristram, was created Baron of Ilowth, I I77. The first time the late Lord Howth's name appeared in the "Irish Calendar" was in 1826 , when he was only twenty-three years of age. After such a lapse of time, it would be more than useless for me to allucle fully to all Lord Howth's performances in the sadlle, or the "doings" of all the good racers and chasers that carried his 
"magpie" jacket. I cannot give any anecdotes of his Lordship's escapades during his school days, nor can I state whether he particularly distinguished himself during his university career, but certain it is that he took a "double first" in many schools through life. Under silk and scarlet he was a conquering hero in countless glorious cross country performances. No better man ever rode to hounds; and as Corinthian and steeplechase rider he was accounted about the best of his contemporaries. When a very young man, his name became a household word in racing circles, not only at home but beyond the "silver streak." The first horse he raced was in I 826. This was Penguin, by IVaxy, for the King's Plate, at the Curragh April meeting. Five started, viz., Mr. Savage's Munster, Marquis of Sligo's Straw, Mr. Hunter's Hypocrite, Mr. Caldwell's My Mary Anne; and Penguin. It was a great race, and was won after four four-mile heats, by Munster, ridden by Will Conlon of the Curragh. In the June meeting following, Penguin won a heat for the King's Plate, but broke down and ended his racing career in the second go. Two years afterwards, Lord Howth again raced a horse, Modesty, which ran unplaced for the Corinthians at the Curragh. Mr. M'Donogh rode her; Mr. Tom Ferguson won on Queensbury; Mr. Mayne was second, on brother to Altmont, Mr. Villiam Disney, third, on Johnnie Bush, and Mr. Walter Purdon was clistanced on Mr. Bingham's Puritan. At the October meeting, at head quarters that same year, Mr. Bingham's Governor beat Lord Howth's Soap in a match for 50 sovs. each, two miles. The first time I find his Lordship's name given as riding a race (and I looked carefully over the old 
calendars) is when he is mentioned as having piloted an unnamed horse, by Sir Roger, the property of Colonel Armstrong, for the Corinthian Stalies, at the Curragh June meeting, 1829. He was not placed in a large field; and after three evenly contested heats, Colonel Gilbert, on Lord Portarlington's Cour de Lion, beat Mr. Disney on Talma. At the Curragh April meeting, 1830, Lord Howth won his first race, and rode himself. It was on Queensberry. He carried 12st. 13lb. for the Corinthians; five ran. Queensberry was the first, and Lord Portarlington's Dandy, ridden by that celebrated horseman, Captain Petat of the 7 th Hussars, was second. For the third heat, Dandy came in first, but the stewards awarded the race to Queensberry ; because, when just near the judge's chair, Dandy turned savage, and caught the stirrup leather and boot of Lord Ilowth in his mouth, and thus interfered with his chance.

For several years after this victory his Lordship rode in nearly all the Corinthian races at Irish meetings, sometimes for Queen's Plates too, and frequently in steeplechases in England and Ireland; and from that time up to his death he always had several race and steeplechasę horses in training. At this period, the patrons of the turf were very fond of making matches, and it was not unusual to see eight or ten decided during a Curragh meeting. At a reunion there in June, 1830 , Lord Howth's Queensberry, I 2st., beat Mr. Forbes's Snoolss, I Ist., in a match for 50 sovs. each, one mile, owners riding; and on the same day Mr. Forbes's Little Shakes beat Lord Howth's Long Legs in a match of 50 sovs. each, three miles. At this period there were four 
meetings held annually at the Curragh, and the racing continued at each of them six days in the week; and in June there was always a second Monday. On Monday, November 15 th of that year, Mr. Forbes and Lord Howth had two matches over the old Ashbourne steeplechase course. In the first, Mr. Forbes's Zanga, i ist., beat Lord Howth's Fiddler, I ist. In the second Lord Howth's Johnnie, I 2st., beat Mr. Forbes's Little Shakes, IIst. In both the owners rode, and the stake was 100 sovs. each. Mr. Forbes was an officer in the Coldstream Guards, the owner of several racehorses, and a first rate horseman. In I83I his Lordship had several racehorses, and was very fortunate, particularly in matches. One of the most interesting and exciting races of the year was a sweepstakes of 25 sovs. each, over Connolly's mile, between Lord Howth's Lancet, Iost. Iolb., Lord Clanmorris's Tidings, I 2st., Mr. Forbes's 29th of July, Iost. Iolb. Owners rode, and they finished in the order written. In 1835, Lord Howth was appointed Steward of the Turf Club; the other two were Colonel Westenra and Mr. John Maher, M.P., Ballinkeele, Enniscorthy. With the exception of the Sligo whip, which was won by Emu in 1836 , no very important race was won by his Lordship's horses. "Little fishes were sweet" to him, and he preferred running his horses in Corinthian races, in which he could ride himself, and in small stakes, to flying at bigger game. With Emu, the Little Clown, Claret, and others, he won many races.

In 184 I, the "team" were in great "form," and comprised C. G., the Colonel, Spring-heel'd Jack, Doctor Sangrado, Paste, Penelope, filly by Barebones, Magic, Profligate, Flash, Augean, Hazard, and St. 
Lawrence. With the last-mentioned four he was very fortunate, and St. Lawrence was probably the best horse in Ireland that year. He was by Skylark or Lapwing, and won, in 1840 , the Gold Cup, presented by His Majesty George III., and other races. In I 841 , he ran twelve times, won nine races, and was second for three. He won the St. Lawrence Stakes of 180 sovs. at Howth, four Queen's Plates, the Lord Lieutenant's Plate, the Steward's Stakes, the Kirwan Stakes, at the Curragh, as well as a match, run at the Curragh in September, of 500 sovs. each, four miles, in which St. Lawrence, 4 yrs., 7st. 7lb. (Wynne), beat Lord Milltown's Cruiskeen, aged, 8st. 7 lb. Betting, 4 to I on St. Lawrence. Cruiskeen, I may add, won the Cesarewitch (the first run at Newmarket) in I 839. In I84I, the Peel Cup and the Gold Cup were resigned to his Lordship. He raced no less than twenty horses in Ireland in I84I, and they carried the "magpie" jacket frequently home in triumph. Morpeth, St. Lawrence (sold for a large sum at the end of the year), Dr. Sangrado, and Conclor were the best. Four Queen's Plates and the Lord Licutenant's Plate, were placed to his Lordship's credit, as well as several other valuable stakes; including the first Angleseys he won, and the Sligo Stakes. Five ran for the Angleseys, but Conclor, by Economist, from IIumming Bird's dam, won easily.

Having sold several horses and sent a few to England, the only ones he ran in 1843 were Condor and Morpeth, and he sold them both before the end of the season. During the next year his colours were carried a few times, but never successfully. However, in 1845 he hacl a large stud together 
again, and Switcher, IVasp, Crosby, and Wolf Dog all won races for him.

Any horses Lord Ilowth had in England were trained at Danebury, and some of his best feats in the saddle were performed at Croxteth Park, Eglinton, Bibury, Warwick, and Goodwood. The first animal his Lordship sent to Danebury was St. Lawrence. He won the Stand Cup at the Liverpool July meeting, I 842 , beating several first-class horses, including Roscius, winner of the Cambridgeshire two years previously; Satirist, winner of the St. Leger; and Vulcan, winner of the Cambridgeshire. Mr. Gully purchased St. Lawrence from Lord Howth, and he won thirteen races during the following racing season. Lord Howth won the Chester Cup in 1848, with Peep-o'-day-boy. The first brood mare his Lordship had was Remnant, the grand-dam of Wire. He purchased her from Lord Sligo, and had several good horses from her-Doctor Sangrado, Tom Pipes, Wall-flower, and Seaman, to wit. Another he purchased from Lord Sligo, was Ezora. It was through Foinualla, a Birdcatcher mare, out of Brandy Bet, the dam of Cruiskeen (winner of the first Cesarewitch and Chester Cup), that Lord Howth gained classic honours on the turf, and at the stud. She bred for him Kingstown, second to Wild Dayrell, for the Derby, and Mincepie, winner of the Oaks. Lord Howth also had Ackworth, winner of the Cambridgeshire; Christmas (dam of Gleenavena), Mistletoe, Merry and Wise, and Sutton, winner of the Cambridgeshire; Plum Pudding, Snapdragon, Chocolate (dam of Malahide). From Fidget he bred Lambay, Termagent, and Dancing Master. Dahlia bred him Dr. O'Toole and Ireland's Eye. He also bred Indi- 
gestion, Dr. O'Leary, and many other "clinkers." Mincepie, Dr. O'Toole, Ackworth, and Kingstown, ran in Mr. Hill's name; he had shares in them. I must conclude my brief memoir of Lord Howth by assuring my readers that he was one of the best "all round" sportsman of his time, and was for years the staunchest patron of the Irish Turf. His cheery humour and many estimable points of character ensured for Lord Howth a widespread and deserved popularity.

I give a chapter to each of the other subjects of Mr. Hayes' portraiture. 


\section{CHAPTER XXII.}

THE CORINTHIAN CUP PICTURE-CONTINUED.

Number three on the key before me is Mr. John J. Preston of Bellinter, Navan, on Auburn, a very distinguished and popular sportsman, who, "years ago," gained an enviable and deserved reputation as a horseman and patron of racing and hunting. His name appeared as an owner of horses in "The Irish Racing Calendar" as early as I840; and his cap and jacket was first carried by Rising Sun, when that son of Recovery ran unplaced for a sweepstakes at the Meath Hunt Meeting in 1840 , on the same afternoon that Brunette, then the property of Mr. Alley, won the Meath Hunt Cup, value Ioo sovs., (given to be run for by Mr. Preston, who for several years gave a valuable trophy for competition at that reunion). On the second day of the meeting Rising Sun, ridden by George Molony, won the Ladies' Purse. His next horse, Enterprise, ran but once, that was at Bellewstown, where he failed to gain a "bracket." In September, I840, Mr. Preston won his first race at the Curragh, when Sunset beat Brenda, a mare belonging to Mr. "Jemmy" Knaresboro, in a match for a hundred aside "over the course." Some months afterwards Sunset won a small stakesat Trim. In March, 1845, Mr. Preston rode Brunette for the Kilrue Cup. She was placed fourth, Mr. Hicks' Regulator, under 
the careful guidance of Mr. Jameson, winning. In 1843, Mr. Preston had several racers and chasers, including Knight of Tara, Great Wonder, Brunette, Morning Star, Zinc, sister to Poacher, The Bard, Mountain IIare, IIarpy Eagle, Noble, Vallerie, and Clear Air; and Great Wonder won three races, in. cluding two Queen's Plates. Tara, a grey, by Manfred won a couple of stakes; and many a time Mr. Preston "cut down" a Ward, Meath, or Kildare "field" on him. Brunette won the Westmeath Urn, the Bellinter Cup, Kilrue Cup, and a sweepstakes of 150 sovs. at Dunboyne. During the following year, he raced several horses, but Brunette was his only "bread winner." She won the Westmeath Urn, Kilrue Cup, Foxhunter's Stakes at Ormond, and 120 sovs. at Limerick. In I 845 Mr. Preston's lucky star culminated. Norma won some races for him, Mountain Hare increased the balance at his bankers considerably, so did Mordaunt, and Sir IIerculeus's most distinguished daughter won the Kilrue Cup, Westmeath Urn, Foxhunter's Stakes at Ormond, the Meath Gold Cup, New Melton Stakes at Cahir, and the Commissioners' Plate at Cashel. Her stable companion, Hark Over, then a two-year-old, and very speedy colt, beat her half brother, Mr. Knaresboro's Hark-in, in a match for $€ \mathrm{I}$ oo a side, at the Curragh September Meeting. This performance was followed up by running third for the Pagets, to two first-rate horses, Chanticleer and Burgundy. Chanticleer divides with Faugh-a-Ballagh the honour of being Birdcatcher's best produce. He was bred by the late Mr. Christopher St. George, was got by Birdcatcher out of Whim, a grey mare bred by the late Colonel Westenra. As a racer the dam failed to pay her 
way, and was purchased from the Colonel by Mr. St. George, who put her to the stud.

Chanticleer's first race was when he finished third to Lord Howth's Mermaid and Mr. J. Preston's Osprey, for the Angleseys. Osprey was ridden by Bell, who came over from England specially. The filly appeared to have the race in hand, but Bell, holding his opponent too cheap, lost. He saw his mistake, and was so sorry that he declined a fee for riding her. Chanticleer was purchased, in 1847 , by the late $\mathrm{Mr}$.

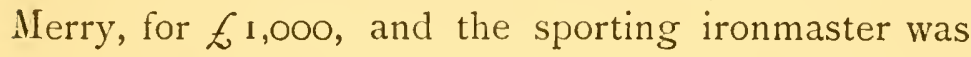
little known on the turf till he startled the world with the "gallant grey," when he achieved a series of brilliant triumphs in 1848 , including the Goodwood Stakes and Doncaster Cup. In 1845 Chanticleer started three times, without winning; he won a few races at the Curragh in 1846 . In 1847 , he started nine times and won six:-Queen's Plate, Curragh, April, $£$ roj; Queen's Plate, Curragh, June, $£_{105}$; Queen's Plate, Curragh, June, $\ell_{105}$; Queen's Plate, Curragh, June, $\ell^{105}$, The Glasgow Cup, at Paisley, $£ 100$; Silver Bells at Paisley, $£ 60$; total, $£ 580$. In I 848 , he started fourteen times, and won ten :-Manchester Welter Cup, $£ 100$; Castle Irwell Stakes, $£ 90$; The Northumberland Plate, $£ 995$; The Newcastle Gold Cup, $£_{160}$; The Goodwood Stakes, $£_{1}, 120$; The Stirling Gold Cup, $£^{21} 5$; The Ayr Cup, $£ 100$; The Doncaster Cup, $£ 470$; Queen's Plate at Caledonian Hunt, $\ell_{105}$; Queen's Plate at Caledonian Hunt, $£$ ro5; total, $£ 3,460$. In 1849 , he started nine times, and won twice:-The Newcastle Gold Cup, $£_{140}$; Lichfield Queen's Plate, $\ell_{105}$; total, $\ell^{245}$. Started forty-one times, won twenty-one. Total winnings, $£ 4,730$. 
In 1846, Brunette won the Foxhunters' Stakes at Lismacrory, and the Kilrue Cup for the fourth time, the Grand Handicap at Worcester, and Grand Handicap at Hereford. Mordaunt, Bubble, Fullcry, and View-Halloo performed very badly; and Irish King, although one of the best two-year-olds in Ireland, failed to compensate in any degree for their defeats. He was second for the Angleseys, and for a valuable sweepstakes to Horn of Chase. When winning the Pagets, he swerved just below the judge's box, and consequently was beaten by Mr. Whaley's Calcavella. Osprey ran very well for the Epsom Oaks, and won a Queen's Plate at the Curragh.

In 1847 , Brunette broke down; her racing career and her owner's may be said to have terminated about the same time. Mr. Preston has not had a "flyer" since; but Sunblush (second to Anatis in 1855 for the Kilrue Cup), Autumn, and one or two others, carried his crimson and gold jacket successfully. He still attends the principal flat and steeplechase meetings in Ireland, and is one of the oldest members of the Irish Turf Club. He established a race meeting at Bellinter some years ago, and is a very generous contributor to the race fund every year there, and to the Trim meeting also. He keeps an excellent pack of harriers, and has a large stud of hunters. He rides straight across country, and enjoys the hunting as thoroughly as he used to thirty years ago, when the names of Preston and Brunette were household words in sporting circles. In a word, Mr. Preston discharges all the duties appertaining to his position as a country gentleman and large employer in a manner which has won for him the esteem of all who have the pleasure of his acquaintance. 


\section{CHAPTER XXIII.}

THE CORINTHIAN CUP PICTURE-CONTINUED.

A LitTle in the background, on a favourite hunter, is the tall figure of the Marquis of Drogheda. The likeness was an admirable one. Henry Francis Seymour Moore, 3rd Marquis of Drogheda, K.P., P.C., late LieutenantColonel of the Kildare Rifles, Ranger of the Curragh of Kildare, and Lieutenant of Kildare, the only child of Lord Henry Seymour Moore and Mary Parnell, second daughter of Sir Henry Parnell, created first Lord Congleton, was born on the 14th of August, I 825 , and succeeded his uncle in 1837 .

The Marquis, who is descended from a very distinguished ancestry, at a very early age went to Eton, and having spent six years there, returned to Ireland and entered Trinity College, where he graduated. After a very long minority, having ample means and an undeniable taste for out-door amusements, he on attaining his majority, became a patron of field sports-hunting, racing, and coursing, to all of which he has ever since been unflinching in his support. When twenty-two years of age, he took the mastership of the Queen's County Hounds; and during his reign, which lasted three years, showed first-rate sport, although many difficulties beset men in his position during these troubled times, the famine years. The first race the Marquis of Drogheda won was the Kildare Hunt Cup, with Improvident, when the meeting was 
held at Teapot Hill, near Nine Mile House. In I 848, at a meeting held at Emo, Queen's County, the Drogheda Cup, value 100 sovs., a donation of the Marquis, was won by his own horse, Westmeath, ridden Mr. J. G. Adair of Rathdair, who has at present a splendid stud of hunters, and occasionally leads a Kildare and Queen's County field in a good run. Twelve months afterwards, Westmeath won the Kildare Hunt Cup, and ran fairly well for the Kilrue Cup, in that memorable struggle over Lucan's high banks and green pastures, when Farnham, Sir John, and Abdel-Kadeı lought a hard battle for that valuable stake. The following year, three started for the Kildare IIunt Cup. It was a grand race, between Mr. T. De Burgh, on Medora, Captain C. Warburton on Switcher, and Mr. "Harry" Moore on Westmeath. Switcher made the running to the fourth-last fence, when the others joined issue, and ran head-and-head to the last one, where IVestmeath was beaten; and, after a severely contested race, Medora won.

A match took place a few days afterwards over the same course, which excited a great deal of interest in the county amongst racing and hunting men, between Mr. T. De Burgh on Medora, and Mr. George P. L. Mansfield, of Morristown, Lattin, on his own horse, Kilmallock. These worthy sportsmen were rivals in many daring feats with the "Kildares," and the respective merits of the men and horses were the subject of many discussions amongst their numerous friends and admirers. One evening, after a brilliant run, they made the match. The conditions were I3st. each, owners up, for 50 sovs. each. After a great race Medora was victrix. Westmeath won the Drogheda Cup that 
year for the second time, and in $185 \mathrm{I}$, the Kildare Hunt Cup and a small sweepstakes at Whitefield, ridden on both occasions by Captain Phillips, a gallant officer of the 43rd Regiment. Strange to say, this horse only ran twice the following year, and that was for the same stakes, over the same courses. He won both, under the careful guidance of Captain Charles Warburton, who piloted him successfully for the Kildare Hunt Cup in 1853 , when this lucky chaser won the much-coveted trophy for the fourth time, and third year in succession.

In 1855 , the Kildare Hunt Cup was again taken to Moore Abbey, as Beware won it for the Marquis. Tom of Tuam came in first, but was disqualified for not having carried $\mathrm{I} 2 \mathrm{lbs}$. extra, as being a winner of twice £50. I will now pass over a few years, merely remarking that Grisella, Templemore, and Ladybird carried the "black and silver," -but were not very successful performers. There was a turn in the tide in 1860 , as at Punchestown, Templemore, ridden by that grand horseman and good sportsman, Mr. George Knox of Brownstown, Curragh, won the Union Plate. During the years $186 \mathrm{I}-2$, his horses did nothing worth recording.

In 1863 , at the Kildare Hunt Neeting, the first race on both days fell to him. The Punchestown Plate he won with Ladybird, and the Naas Plate with Oberon. Both were piloted by "Dan" Meany, and the last-named was purchased, after running, by Lord Henry Bentinck. During the following year the colours were carried only once to victory, viz., at Springhill, where Satanella won the most important race. In 1866, Robin Hood won the Conyngham Cup, and it was 
pleasing to see this valuable stake go to him who made Punchestown what it has been for years pastthe best steeplechase reunion in the world. Soon afterwards he won the Howth Stakes with Clarence; twelve months afterwards the military race at Baldoyle, with La Rose. Mons. Meg, La Rose, and Allen-adale then comprised the stud, but they were very moderate. In $187 \mathrm{I}$, the Marquis of Drogheda, for the first time, won a race at the "Newmarket of Ireland," when King Rène defeated eight opponents for the Trainers' Stakes. I need not refer to the performance of his horses since then. Suffice it to say that Swivel, Pelagia, Minette, Tambourine, Hypatia, Countersign, and Philammon, won races for him. He has in his stables at present youngsters of the highest parentage and great promise, including the two-yearold, Miriam, by Crown Prince, out of Rachel; Frederick William, by the same sire, from Swivel; Sisyphus, by Outcast, from Satanella; and a yearling, Arras, by Kidderminster, out of Swivel.

The Marquis has several brood mares, and it is a noteworthy fact that all the horses he has bred were remarkable for their good looks, and were gifted with size, bone, and substance, which proves that the mares have been judiciously mated, and their offspring carefully tended. His Lordship never allows his horses to be hurried in their preparation, nor thoroughly "wound up" when two years old. I am sure he is not an advocate for two-year-old races, and he has certainly good grounds for opposing those who hold that early training has not a prejudicial effect on the thoroughbred horse. His horses are trained at home, and Monnypenny, who has charge of them, is a master of his art. 
The Marquis of Drogheda is one of the mainstays of the Irish turf, the acknowledged leader amongst Irish racing men, and no person has the prosperity of the turf and its patrons more at heart than he. Many of my readers have seen him at Punchestown, where he is invariably so energetic and indefatigable, that he appears to be ubiquitous, and to have the shoulders of Atlas and the eyes of Argus. He takes the greatest interest in every sporting reunion, and to the evil doers he is a source of dread. How often do we hear, when speaking of some animal being stopped in a race, the query put, "Was the Marquis there?" or hear it said, "Oh, it is well for the owner and rider that the Marquis was not there!" "Johnny Armstrong" has a wholesome horror of his Lordship, the much-feared enemy of the "pull 'em and scratch 'em division."

Irish coursers are indebted to him for giving them his extensive preserves to course over, and he goes to much trouble and expense in order to have a plentiful supply of "fur" on the famed plains of Bourbawn, where lovers of the leash hold some of their most important meetings annually; and those who have ever had the pleasure of attending the dinners of the Leinster Coursing Club, and heard the enthusiasm with which his health is drunk, must have noted that he is an especial favourite with lovers of coursing; and they, as they are bound to, feel much indebted to him for his liberality and kindness. His Lordship is a very liberal subscriber to the Kildare Hunt Club. The "bags" made at the annual battue, and the result of frequent visits of the "Kildares," prove that game of all sorts are to be found in large numbers in the Moore 
Abbey coverts. He is an enthusiastic and successful yachtsman. I should add, that he married, August, 1847 , the Hon. Mary Caroline, eldest daughter of the second Lord.Wharncliffe. To "sum up," I may observe that the Marquis of Drogheda may be said to have played the rôle of a man of the world and a sportsman, and to have acquitted himself to such satisfaction, that there is no more popular member of society in the country.

By the Marquis we find a good portrait of the late Surgeon Rynd, the especial friend of riding men, and than whom there was no more enthusiastic lover of sport in the land.

The place of honour was accorded by the artist to the late Captain the Hon. J. W. Hely-Hutchinson, A.D.C., on Torrent, as he occupies the centre foreground, and the likeness is a "speaking" one. Captain Hutchinson was brother to the late and uncle to the present Lord Donoughmore. Of the many noted sportsmen who died on the inhospitable shores of the Crimea, none were more universally and sincerely regretted than he. In him the turf lost one of its best supporters, the army one of its most esteemed ornaments, and hundreds mourned at his death for a staunch, generous friend and bon camarade, who never failed a suppliant, or quailed before shot, shell, or "yawner." With the lightest of hands, firmest seat in the saddle, and a heart ever in the right place, he was a perfect horseman.

In 1850, at the Dundalk Garrison Races, he was invincible. Three races were run, and he rode the winner of each, including a match for 50 sovs. on his mare Marian, in which he beat an officer of his own 


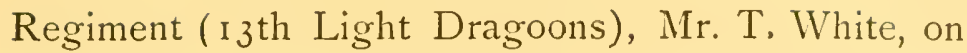
Croom-a-boo, after a great race. He won many races, but never rode a better one than on the late Colonel Richard Bernard's Beware, for the Kildare Hunt Cup in 1854 . Seven started, and it was one of the most severely contested races ever run over that course. Beware, The Dodger, The Squire (winner of the Corinthian Cup in 1853), and Captain Warburton's Disowned were all backed freely. Diamond, Disowned, Knowsley, and Beware kept close company throughout, and Diamond won by a short head. Beware defeated Diamond by a neck for second place. Knowsley finished a similar distance behind her, fourth. Half an hour afterwards "Denny" Wynne won the Farmer's Race, on Haphazard, and then nineteen were weighed out for the Corinthian Cup. So much money was put on Torrent that he started at six to four; and he pulled his backers through very easily. Next day, Captain Ilutchinson won the Welters on Torrent A few weeks afterwards, he rode the same horse for the Kilrue Cup, and he fell over a bank near home. Jumpaway, a four-year-old, by Blackfoot, the property of Mr. M. Dunne of Punchestown, ridden by Mr. Tom Abbott, won. The gentleman taken with the starter's flag in hand is Colonel Campbell of "the Bays," on Free Trade. He rode many winners; won several races for "the" Marquis of Waterford, and could finish as well as any man. A little in the background is Mr. William Kennedy, ex-Master of the Kildare Foxhounds. For his character as a M. F. H. and rider to hounds I refer you to the chapter on the "Kildares."

Mr. Kennedy is the second son of the late Sir John Kennedy, and was born in 1821 . When very young 
he showed his predilection for racing, particularly on the flat, and for many years he stood high on the list of successful gentlemen riders, and was one of the very best Corinthian riders in the country. He had a few horses of his own, too; and with Altro, Arbutha, and Cruisk (brother to Russborough, which ran a dead heat with Voltigeur for the St. Leger), he won several stakes.

Then there is Captain Barclay, of the 16 th Lancers, on Merlin. He is a fine horseman, and won several races in England and Ireland, both on the flat and over the country. He rode many good races in Punchestown. He was second, in 1858 , for the Corinthian Cup on Phœnix, the best chaser in Ireland that day, as proved by his giving Ace-of-Hearts 2st 6lb., and running him to a neck. The Captain's best performances in the pig-skin was his riding Merlin, against Captain Hutchinson on Free Trade, for a Corinthian Stakes, two miles, over the Confy-Castle course on Patrick's Day, 1854; it ended in a dead heat, and spectators were "witched" by the artistic horsemanship of the gallant Lancer and Light Dragoon; and many a shamrock was drowned that night in bumpers to their health.

Over the same course, in a month afterwards, at a military meeting, Captain Barclay won four out of five races run during the day. Mr. J. G. Price, then an officer in the 2nd Dragoons, was a good rider too, and was second for the "Cup" this year on The Squire. He was thought to ride more "wickedly" to Hounds than any contemporary, and was called by some the "Demon" horseman. Few stronger men in the saddle were ever known. Major Dickson, 
who afterwards commanded the gallant "Red Lancers," Mr. Thomas Boyce, just then entering on a career of victory, and Captain Halton, were officers of the same Regiment (the i6th Lancers). They were rivals in many cross-country tourneys, popular sportsmen, and good riders. And I may say so too of Captain Chichester, the only representative of the 7 th Dragoons in the print.

The artist hit off to a nicety the expressions and features of Mr. (afterwards Major) Wilkin; and this plucky Hussar was at that time, and for years afterwards, a sporting celebrity. $\mathrm{He}$ is taken on The Squire, a good son of Welcome, and on him he had the honour and glory of winning the first Corinthian Cup. I may add, the first really large stake run for in Punchestown. Captain Severne was at the time one of the best men of the day, and the only one that ever won this race twice: first in 1856 , on Mr. Brown's Abdul-Medjed, a son of Blackfoots, when seven ran, and Captain Barclay was second on Major Colborne's Bolivar. Twelve months afterwards he won it again, on Major (now Colonel) Forster's Ringleader, after a severely contested race with Captain Townley on Sir John Power's Fox. Captain Severne still survives to lead his brother Squires, in the hunting field, in his native Shropshire, which he now represents in Parliament. He has also sat for Ludlow, and parliamentary late hours have not impaired his fire with hounds.

The tall figure, aristocratic, and handsome features of the late Marquis of Conyngham were admirably portrayed by Mr. Hayes.

The Right Hon. Francis Nathaniel Conyngham, Marquis of Conyngham, and otherwise much betitled, 
was the eldest son of Henry, first Marquis of Conyngham, by Elizabeth, eldest daughter of Mr. Joseph Denison, of Denbies, Surrey, and therefore cousin of the late speaker of the House of Commons, Viscount Ossington. He was born in Dublin in June, 1799, and died, at his residence, Hamilton Place, Piccadilly, July I 876 . When a child, the late Marquis was page of honour to the Prince Regent. When young he entered the Life Guards. On the death of his eldest brother, Lord Francis Conyngham, he entered Parliament as member for Donegal, and retained his seat until he succeeded to the Marquisate in $\mathbf{1} 832$. He was for some time Under-Secretary of State for Foreign Affairs, and a Lord of the Treasury. When raised to the Upper House, Earl Grey offered him the appointment of Postmaster-General, which he held during the time his party were in power, and on their return to office, he resumed the position, which he filled until his appointment as Lord Chamberlain to King William IV., and Privy Councillor. He filled the same important office during the earlier years of the reign of her present Majesty. Many years before his death the Marquis retired almost entirely from public life, and lived generally in Ireland, at Slane Castleone of the most beautiful mansions in this countrycharmingly situated on the banks of the river Boyne. The house, grounds, and stables are all well worth seeing, and there is a magnificent collection of old china and objits de luxe, as the Marquis had a great taste for the Beanx-Ar:s. He was devoted to yachting, was commander of the St. George Yacht Club, and to him belonged the Flower of Yarrow, the Sultana, the Sea Flower, Shamrock, Colville, and also 
the following, which were built from his own lines:The Cecile, 180 tons, Helen, 280 , and the Constance, 350. He was patron of the Conyngham Club. His career as a turfite, though long, was not very brilliant. Many years ago he had a few horses in training at Newmarket with Wm. Day, and soon after his colours -French-grey and cerise-were first seen, he won a sweepstakes of 500 sovs. (I 2 subs.) with Gayhurst, ridden by Buckel ; with Mansfield and Royal Oak he won some minor races. In 1850, the Marquis of Conyngham formed a small breeding stud, and became a member of the Irish Turf Club. In 1852, he won his first race at the Curragh with Thunder. In 1853, his Lordship purchased the famous Sultan, then a yearling, and in a year afterwards won some races with him, Lightning, and other horses. In the following year he was successful with Iros, Simpleton, Stella, and Sultan. The last-named won the Madrids and other stakes, and was then sent over to Woodyeates to be trained for the Goodwood Stakes, for which he was not placed. He, in 1855 , ran badly for the Cesarewitch, but proved himself to be a great horse in a few weeks afterwards by winning the Cambridgeshire, carrying $7 \mathrm{st}$. $6 \mathrm{lb}$., ridden by Tim Goater; the odds were 4 to 1 against him, and twenty-one ran. I believe Lord Conyngham's relative, the Marquis of Anglesey, was then part owner of Sultan. At the June Meeting that year Stella won the first class of the Irish Oaks for Lord Conyngham, and since then Dancing Master, Spinster, Vine, Blind Harper, Marmion, General, Dr. Syntax, Woodranger, Saucy Boy, Watchman, Spring Daisy (now called Revolver), Hot Shot, La Rose, Boreas, Vermicelli, Ballet-Girl, Outcast Bee 
(second for the Angleseys in 1869), Soufflê, Athens, Macbeth, Avant, Courier, and others, carried his pretty colours, and nearly all of them more than once successfully. On the whole his Lordship was decidedly unfortunate, for none of our most valuable races fell to him, notwithstanding his long connection with the turf. He was a generous contributor to the funds of Bellewstown, and many other Irish race and steeplechase meetings, and one of the principal shareholders in the Palmerstown Breeding Association. In 1866, in order to encourage the supporters of that stud farm, he bought all the yearlings reared there, with one exception. He gave $£ \mathrm{r}, \mathrm{oco}$ for eleven. They were the first lot ever bred there, and the average price was higher than that realised at any subsequent sale of the Palmerstown youngsters.

He sent them to Newmarket to be trained, but they were all bad. The horses he had in Ireland were prepared for their engagements by James Murphy of Conyngham Lodge, and after his death by his son James, and some of them at home by his Iordship's private trainer, Moran.

I should add that the late Marquis was married to Lady Jane Paget, daughter of the first Marquis of Anglesey. He was very popular in Irish and English society, and especially so with his tenantry.

One of the most noted sportsmen in the beautiful water-colour is Lord St. Lawrence (now Lord Howth) on Mushroom.

William Ulick Tristram St. Lawrence was born on

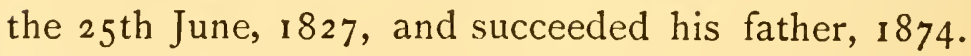
He has been Lieutenant-Colonel of the County Dublin Militia, and was formerly a captain in the 7 th Hussars. 
He was elected, in I 868, as member for Galway borough, and represented that constituency until he succeeded his father. As was only natural, from his earliest years, his Lordship was devotedly attached to field sports. And there is not, amongst the many lovers of manly sports and pastimes in Ireland, a more ardent devotee of each and every one of them than he, nor is there one who takes a greater interest in the well-being of the legitimate and illegitimate branches of the national pastime. As a rider on the flat and over the country, as a rider to hounds and as master of hounds, he is entitled to the highest place. When Punchestown was in its infancy he laboured indefatigably in its behalf. In Galway he established a meeting of the first order. For the Howth and Baldoyle reunion he worked wonders, and his labours were unselfish; he was industrious, not for his own weal but for that of his brother-sportsmen. No one can accuse him, not even the most narrow-minded, of having any personal motive in his zeal as a promoter of racing. He appears to have an especial taste and talent of a high order for framing articles; and to his successful endeavours in this respect we are, to a great extent, to attribute the flourishing condition of the prospects of the patrons of racing. And if his Lordship had succeeded in carrying some of the resolutions he brought before the rulers of the turf, the executives of race-meetings, the owners of race-horses, in a word, all who make up that great republic, the turf, would be even better satisfied than they are. During the days of Lord St. Lawrence's youth he delighted to wander through his father's stables, admiring the many equine worthies which made up the "string," or 
through the paddocks, looking at the brood mares and their offspring as they gambolled o'er the luxurious sward.

When serving in the 7 th Hussars, his Lordship had the good fortune to have as brother-officers many sportsmen good and true. In every Irish province, in most English shires, he has performed extraordinary feats in the hunting-field. As a matter of course, he has had some very severe falls, but they do not appear to have shaken his iron nerves or damped his keen love for the "noble science." Elsewhere I have written of him as a master of foxhounds. I shall now refer to some of his many exploits on the turf in this country. At the Phœnix Park Military Meeting in 1846 , he rode his first race on a filly, named The Witch, belonging to Mr. Littledale; she was second; her owners' Maid of Erskine, piloted by Captain Erskine, winning. That same evening a large assemblage witnessed a fine race between Colonel Campbell on Nubian, Captain Erskine on Crib, and Lord St. Lawrence on Mouche; they finished in the order written. Next day, he was second on Vesture to Colonel Campbell on Crib, and immediately afterwards won his first race, riding Crib; Nubian was second, and four others were "tailed off." Next day, Colonel Campbell, on the Squire, defeated his Lordship on Gadfly, in a match, 50 sovs. aside, one mile and a half, lost. each. He rode six races at this meeting. During the years 1847 and 1848 , he did little in the pig-skin. In 1849 , he rode his own horse, Paragon, for the Kildare Hunt Cup at Punchestown, and was placed fourth in a field of eight; and during the next few years was up in several Corinthians, but though a 
most artistic rider he failed to win races. But so it is on the turf. "Dame Fortune" never establishes her sex more fully than in her treatment of racing men, she appears to deal out her favours to them in a most capricious, unnatural, and often unjust manner. At the Howth and Baldoyle Meetings, in 1854 , Lord St. Lawrence's Brown Bess (Colonel Campbell) walked over for the Tantivy Cup; and next day, his Lordship rode a grand race on Mr. Atkinson's Borgia for the Renewal of the Warblers, but was defeated by Captain Hutchinson on Kate. The second day, on his own horse, Souter Johnny, he was third in two heats to $\mathrm{Mr}$. "Cootie" Hutchinson on Matilda-a speedy daughter of Bird Catcher - and Captain Hutchinson on Cyprus, for the Helter Skelter Stakes; and on the same day, second of sixteen starters, on Souter Johnny, for the Cigar Stakes, to Captain Halton on the favourite, Mr. Whelan's Robber.

A month afterwards, Lord St. Lawrence won a race at the Heath of Maryboro', defeating several opponents. In 1855 , he supplied the favourite for the "feature" of the Kildare Hunt Meeting, the Corinthian Cup, a mare called Miss Bayley; Captain Slade, who lately commanded the King's Dragoon Guards, rode her, but she blighted the hopes of his Lordship and a legion of well-wishers by coming to grief at "the double." On the same day, Miss Bayley made a suitable retraction for her transgression of the morning by winning the Military Cup, beating fifteen opponents. Lord St. Lawrence soon afterwards piloted the winner of the Scurry Corinthians at the Curragh. In I 855 , he rode a few races to which I need not refer; but I am sure he never finished better than on Rakeaway, at 
Baldoyle May Meeting, 1856 , for the Corinthians. It' was a great race between him, Mr. WVilliam Kennedy on Viceroy, and the late Mr. "Willie" Long on the late Lord Howth's Bulldog, the winner, Rakeaway was second.

On reference to the "Calendar" of 1857 , it will be seen that Lord St. Lawrence's Lobster, ridden by the late Colonel Bernard, beat Sir William Gordon on Ballina, and six others, for the Kildare Hunt Cup. And a month afterwards, Lobster, again ridden by Colonel (then Captain) Bernard, won a valuable steeplechase for his Lordship at the Irish Grand Military Meeting, over the old Ashbourne course. Before many' weeks elapsed, Lobster again carried the colours to the front at Kilkenny, this being his third win without an intervening defeat. But he was beaten soon afterwards, after a game struggle, at Baldoyle, for a flat race, by Mr. William Kennedy on Lord Waterford's Bonnivard. In 1858, his Lordship's Brandon (Captain Crymes) won the Kildare Hunt Cup. Twelve months afterwards, his Lochnane, ridden by Mr. Boyce, was beaten for the same race by his only opponent, Mr: Aylmer's Arab Maid (dam of Zuelika, Huntsman, Zoibede, Sultana, Abdallah). The colours were then laid aside for a year, to be unfolded once more at Punchestown, when his Lordship's Fancy, ridden by the late Captain M'Craith, won the Kildare Hunt Cup. That was not his only win that day, as Schamyl, ridden by Jem Monahan, won the Punchestown Stakes. Not only twelve months, but as many years elapsed before Lord St. Lawrence's name was again included in the list of winning owners, and then he won the Kildare Hunt Cup 
with Susan, steered by Captain Smith, after a dead heat with Mr. Forbes's Hock; Ayrefield, another of his horses, was third for the same race, a year afterwards, and in $18_{77}$, his colours were carried a few times unsuccessfully.

Ilis Lordship is a Liberal in politics; is unmarried; he is one of those who appreciate racing as a national pastime, and not merely as an instrument for gambling. En fin, he is a sportsman sans peur et sans reproche-

"Loving the sport for its dear sake alone; Hating the base defilers of its fame!" 


\section{CHAPTER XXIV.}

\section{MR. JOHN HUBERT MOORE.}

I VENTURE to assert that the following brief memoir of the gentleman whose name figures at the top of the page will be read with interest. On both sides of the Shannon, as well as of St. George's Channel, he has a legion of friends. Over the stone-walls of Galway, the banks and ditches of Leinster, and the oxers of many an English shire, he has, by his brilliant style of riding to hounds, established his undeniable claim to the distinction of being regarded as a "first-flight man."

In the land of his nativity, the cordial greetings invariably accorded to him when his blue-and-white jacket-colours familiar to every Irish racing man-is carried successfully, is a proof of his popularity. And those who know him best will coincide with me when I say that he is a "sportsman complete."

John Hubert Moore was born, in 1819, at Shannongrove, in the county Galway; and is the eldest son of Captain Garrett Moore, of the younger branch of the O'Nloores, who were, in 1664 , banished from their territory of Leix, in the Queen's County, to Connaught, by Cromwell, who believed all who were in that province to be beyond the pale of civilisation.

O'Byrne, in his History of the Queen's County, 
writing of the O'Moores, says: "They had for ages to struggle against evil vicissitudes; for ages hostility bent her bow against them; for ages they withstood the malignity of the Saxon spoilers, who are now victorious over them; but history and tradition alike declare their fall to be effected by treachery. It could not be possible, amidst the plots and massacres of the time of Mary and Elizabeth, that the fiery, enterprising, and noble spirit of the O'Moores could remain calm and rest in peace while the enemy destroyed their country. No; all honour to their name, they rose in the face of countless foes. The military spirit of the O'Moores was such that F.ngland had to break by treachery and violence what she could never bend to her will, even when she descended to bribes and promises the most lavish.

"History, ancient or modern, gives no account of any family more brave, devoted, or constant to their motto: Scmper constans et fidelis.

"Of all Irishmen, the O'Moores were the most noble and valiant. We read of the Queen's O'Dempseys, the Queen's O'Connors, the Queen's Dunnes, but we never find the Queen's O'Moores.

"An eternal glory to their name! they fell, as heroes should, with the dazzling lustre of their fathers' names around them. For 2,764 years they flourished faithful and true; and, if all the Irish had been as valiant as the ever-to-be-venerated O'Moores, no nation in the world could have overcome them. They stood as brave as lions in their woods, and on the bounds of their principality won by acts of gallant bravery. They laid down their lives for their country and religion, and the Saxon enemy for ages could only step into 
power over their dead bodies. It stands evident that the O'Moores were a very dearly loved people. Of each O'Moore, the words of the poet may be used:

" ' O'Moore, untainted by flight or by chains, While the kindling of life in his bosom remains, Shall ever exult, or in death be laid low, With his back to the field, or his feet to the foe.'

"They could not bear the whips and scorn of time, the oppressor's wrong, the proud alien's contumely. When they hurled themselves against a remorseless power, they left us a glorious example that, if we follow, they have not lived in vain:

" For lives of great men all remind us

We can make our lives sublime, And, departing, leave behind us

Footprints on the sands of time.'"

John Hubert Moore seems to have inherited a love for wild sports, to keep him out of the way of which his parents consigned him to the care of Dr. Jameson of Carlow while very young. At this excellent school, however, he appears to have met with kindred souls in the Alleys of Dublin, in after years masters of the "Wards ;" the Palmers of the Queen's County; the Droughts, and others, all of whom, in after-life, excelled in field sports. Entered at Trinity College at an early age, we find him holding his own in the "first-flight" with the "Wards," on a thick bay, Bachelor; and there are many still spared who remember the boys of that flight: Mick Yourrell on Dan O'Connell, Captain "Charley" Forrester on Lady Longford, Clarke, Hicks, the Alleys, John Preston of 
Bellinter, Lord Howth, and the everlasting Charley Brindley.

He subsequently resided on the borders of the King's and Queen's Counties, where for two seasons he hunted with a fine pack under the management of that famous sportsman, Mick Drought, than whom no better master or more hospitable soul ever held a horn. Thence circumstances brought him back to his native county, where he became the intimate friend and rival in the field of John Dennis, familiarly called "Black Jack," then master of the renowned "Blazers." At this period-about the year 1844 -he seems to have commenced the indulgence of that passion for steeplechasing he has ever since, under varying circumstances of difficulty, clung to; and with Miss Mathews, Silence, Rasper, and others, he might be seen doing the five-feet-walls, as the chasers of to-day fly the wattle-fence of modern misgovcrnment.

About this time, too, we find him the constant companion of John Longworth of Glynn, who then, and for many years after, hunted Westmeath and part of Roscommon county, at his own expense, rivalling, in the glory of fox-hunting, that prince of good fellows and gentleman and sportsman, the late John Eyre of Eyrecourt Castle, county Galway, whose countries the river Shannon divided, and who was killed from a fall in the hunting-field, and can never be forgotten by those who knew him, or ever heard him cheer on his grand pack to the death. We also find Mr. Moore hunting, and our record says, "going well," in the splendid Lower Ormond country, then hunted by a pack the property of Mr. James Drought.

Soon, the fearful famine and Lancled Estates 
Court revolution shrouded in gloom the events of the time, and the subject of this biography, while endeavouring to float the family estates in the rushing torrent of overwhelming difficulties, was a marked man; twice fired at, and once saved, when his destruction seemed almost certain, by one of the party sworn to take, we might say, that charmed life away; but, at the last moment, it appeared that the would-. be assassin's heart was touched, and could not forget acts of kindness received and love engendered while sporting together with his intended victim, his master in happier times. He created a panic amongst his companions, and in the hands of Providence, saved a life-of such impulses Ireland can and ever will be able to boast.

Again, in 1853 , we find Mr. Moore residing at Moatfield, in Tipperary, as popular as if nothing had ever occurred; and in 1855 , he rode his famous, but, therefore, unmanageable hunter, Express, by Harkaway, Ist. 3lb. overweight, for the Galway Members' Hunt Race, over the Knockbarron course, four and a-half and five feet walls, three miles; and although he had wasted considerably, he could not scale less than I3st. 3 lb., with a 5lb. saddle; breaking a leather a mile and a-half from home, he was, of course, much exhausted by the hardest of pullers, yet he was second, beaten only by a length. Eight started, and Mr. "Val" Blake's grey gelding, Gortnamona, ridden by Mr. "Tom" Naghten, owner of that great chaser Thomastown, won. He was again second for the I4st. Welter Stakes at Oundle, in Leicestershire, a few months afterwards; and, strange to say, came second in the $16 s t$. Welter Stake next day, over 
a rough, natural country, three miles, run in $7 \mathrm{~min}$. and 30 secs., the fastest welter at such weights on record.

In 1856, Express ran third, in a field of nine, for the Punchestown Welter, ridden by Captain "Charley". Warburton. He was then sold to Mr. Studd, the owner of that successful aspirant for Grand National honours, Salamander.

About this time, Mr. Moore had such animals as Sir Hercules, Emigrant, Seaman, Nugget, Huntsman's Horn, Fairy Saint, Fairy King, The Rake, The Witch, Grizette, Express, The Friar, Mont Blanc, Ugly Buck, Kilcock, Cooksboro', The Dodger, Ballycasey, and many other good horses. Leaving Moatfield, owing to ill-health, he settled in Cheshire. Thence we find him bringing over such horses as the flat racer Joey Ladle, Tom Thumb, and Doctor De Jongh (horses that had never seen an Irish bank), to win the Downshire and Drogheda Plate, at Punchestown, in I868, and several other races. But, becoming afflicted with rheumatic gout till almost a cripple, Mr. Moore again gave up the horses, and contributed some of the highest priced animals sold at the great Combermere sale of 1870 . Intending to fall back on a warmer climate, but having some horses still in Ireland, and many friends whom he wished to see, he, with great difficulty and pain, came across the channel, and found himself in the cheery company of his old friend, Allen M'Donogh, at Athgarvan Lodge; where in a few days the change of scene, and the air of the far-famed Curragh, so rekindled the old fire, that he decided on taking Jockey Hall, and forming the present formidable stable. I need not divell upon the great success of his undertaking, but I may 
observe that last year the stable won (with fourteen winning horses) forty races, the sum realised amounting to the handsome total of $£ 4,3$ I $2-£ 1,860$ being spoil from the Saxon.

This worthy sportsman may now be seen in good health, perfectly free from his old enemy, still enjoying a burst with foxhounds, when scent lies and the pace is good, with all the keen enjoyment of an Irish foxhunter of the good old school, who ever scorned to look for a start till the hounds were on the line, and never pressed the puzzled pack while working out that wonderful riddle, scent.

Being of such quality, is it astonishing that Mr. Moore and his belongings occupy a front place among Irish sportsmen? In wishing him many more pleasant years amongst them, I only share the feeling which is deep in the hearts of the countrymen of a fine hale Irish gentleman, of the true old stock. 


\section{CHAPTER XXV.}

\section{MR. ALLEN M'DONOGH.}

As I have promised to record in it the "doings" of the most remarkable patrons of field-sports, for the entertainment of those who honour my maiden essay as an author with their kind support, I think this work would be deficient, were on its pages not inscribed, in a very special way, the name of Mr. Allen M'Donogh. $\mathrm{He}$ is one of the most noted of the many sporting celebrities who have, by their straightforward conduct, their love of sport, and their wonderful feats in the saddle, tended to make Irish sportsmen famous throughout the world. Mr. M'Donogh was born, in I 808, at Villmont, one mile from Portumna, in the County of Galway. When a mere boy, he evinced an ardent love for silk and scarlet and out-door sports of all kinds. His father, although he never raced a horse, always kept a stud of good hunters. The subject of this notice remembers to have seen, when very young, eight of his father's horses (value for at least $£ 800$ ), shot one morning, owing to their being affected by that terrible malady, glanders, then much more prevalent than now. When he was eight years old, Mr. M'Donogh's father died, and a few years afterwards he was sent to Tullamore College, to be inducted into a knowledge of syntax and prosody, but he evidently preferred Diana to all the gods and goddesses he met with in his classical readings. He was no sooner in the academy than he became "home sick ;" and, longing for his equine and canine pets, and to "tread once 
more his native heath," he, three days after his arrival there, "stole away," and walked thirty-two miles back to his home, where he arrived at two o'clock in the morning; and fearing to meet his relatives, he lay down in the pleasure-grounds, where he was found some hours afterwards asleep. He was then sent to Shinrone, where he finished his school-days. When a boy, he used to spend most of his time with his neighbour and uncle, Mr. Doolan of Derry Lodge, Shinrone, who owned Paddy from Cork, Nabocklish, and other good chasers, and kept a pack of harriers. Mr. M'Donogh was generally either in the kennel, the stable, or the pig-skin. In treating of him as a horseman, I may say that he met with few equals in his many exploits on the race-course or in the hunting-field. He is a real artist, and combines an elegant seat, with fine hands, quick eye for a country, and he never loses his head; no matter how great the difficulty or exciting the finish, "Allen" was always as "cool as a cucumber." He adopted the Chiffney secret of riding to a nicety. You may have never heard of the "Chiffney secret," so I will tell you of it. Some years ago, a person advertised in The Field, "Chiffney Secret of Riding," price $10 s .6 d$. The proprietor of the paper did not suspect any fraud, and several others were equally "sold," when having enclosed the money, expecting to receive in return a book on horsemanship, they got instead the following brief advice:-

\section{"The Chiffney Secret of Riding.}

"Your head and your heart keep boldly up, Your hands and your heels keep down, Your legs close in to your horse's sides, And your elbows close to your own."*

* Jack Haslin, an Irish celebrity (D. Wynn's instructor), used to say, "Hands low, elbows close, and a stiff shin." 
The first cap and jacket Mr. M'Donogh wore was when he rode Hugo de Lacy for the Hunt Cup, at Tipperary, for Mr. Doolan. He then weighed only 5 st., and won. His first racer was a mare named Gulnare. At sixteen years of age he won a steeplechase on her at Loughrea. He subsequently bought Rakeaway; and he soon brought back some of the purchase-money by winning $£^{60}$ at Athlone, after a terribly severe race of four four-mile heats. Mr. M'Donogh was very ill at the time, and was so exhausted after the last heat, that he had to be assisted back to the scales. He rode Rakeaway in 1834 for the Corinthians at Loughrea, but was beaten. In 1835, Nimrod and Rakeaway were his only horses, and he steered them both for a couple of times, but not to victory. In the following year, Gipsy, Orleans, Sir William, and Now-or-never comprised his stud. At the Curragh June Meeting, on Gipsy, Ios. 7lb., he beat Mr. Powell's Majorum in a match, two-mile heats, for 50 sovs. each PP. ; and on the last day of that same re-union, he defeated a large field for the Corinthians on Orleans, a horse by Alcaston, or Philip I. In August, a three days' meeting was held at Howth, called "The Howth Park Meeting." There were four races, all run in heats, decided, and no person was allowed to ride except members of the Howth Racing Club, or gentlemen qualified as for the Corinthians at the Curragh. The piece de resistance was the St. Lawrence stakes, of Io sovs. each, roo added, one mile and a-half heats. The first heat was won by Mr. $M$ 'Donogh on Orleans, beating the late Lord Howth on Emu, after a close finish; Mr. Parson's Persse was third on Mr. Knox's Zora. The second and final 
heats were won by Lord Howth's Delirium (Mr. Mayne) easily. Sir William carried his owner to the fore in a couple of races at Loughrea, and for one at Castlebar, but Now-or-never failed to gain a "bracket" that year, but he subsequently won four years in succession the Ormond Hunt Cup. Sir William made two unsuccessful essays in 1837 . He was a beautiful chestnut horse by Velcome, a perfect fencer, but a very erratic customer. He won several valuable steeple-chases in England. On one occasion, in a race which came off at Neston, near Chester, he beat a large field of first-class chasers, though he fell, and dragged Mr. M'Donogh fully a hundred yards. Shortly afterwards he ran him for a race at Dunchurch ; and he was going wonderfully well, when, at the end of the second mile, a man named Ball rode at him, and knocked him over. Captain Lamb, owner of the Great Vivian, was at the place where the contretemps took place, and saw that Ball had ridden deliberately at Mr. M`Donogh. He pursued him for fully a mile, overhauled him, gave him his deserts-a good horse-whipping. That night, when Mr. M'Donogh was lying in bed, suffering from a broken collar-bone and two fractured ribs, the result of the fall, Mr. John Elmore, the well-known dealer, visited him, and purchased Sir William for $£ 35^{\circ}$. A few days afterwards Lord Cranstown bought him for $£^{\mathrm{I}, \infty}, \mathrm{O}$, and matched him against Lord Suffield's Jerry for $\ell^{1,000}$ a side, four miles, over the Quorn country. Sir William could not be managred by strange hands. Many first-class horsemen were put on him, but he mastered them all. The match was made on a Monday; on the Thursday evening following a messenger, 
all the way from Melton, arrived at Willmont with a letter from the late Lord Howth. His Lordship explained matters, and entreated Mr. M'Donogh to go over, to use his own words, "to get them out of the hole." It was a long journey in those days, when there were no railway lines; however, he went, arrived in Leicester on the following Sunday, saw that the horse was in "blooming condition," and got on his back. "Sir William showed a good deal of temper, but after a length of time he got him over a couple of small fences. The course was an ugly one-post and rails, razor-backed banks, and water, were to be met with in the line. As was generally the case in these days, the track was from one windmill to another. There was an immense assemblage of the "rank and fashion," indeed of people of all classes, to witness the contest. Jerry was favourite, and trusted to the guidance of Jem Mason, who sent him to the front the moment the flag was lowered, to the delight of Mr. M'Donogh, who was afraid to make play, fearing that his horse would baulk. The first fence was a nice bush-fly, and when Jerry came to it, he wheeled right across Sir William, who went straight, flew it like a bird, and won in a walk. This took place in 1839 , and in a year afterwards Jerry won the Liverpool Grand National, beating twelve competitors. I should have mentioned that, in $\mathrm{I} 838$, Mr. M'Donogh had a trio in training, My Lady, Fracture, and Bolivar; on the last-named, a useful son of Tramp, he won the Battersby Whip, with 105 sovs., and the Vaughan Goblet, with 155 sovs., at Howth, but neither of the others brought " grist to the mill" that season.

During the next four years he had no horses in 
training, and rode but few racès. In 1843 , the only win he scored in Ireland was on Tidings, a mare belonging to Mr. Richard Connolly of New Haggard, Trim. It was the Hunt Race at Trim, of 50 sovs.: added, four miles over the old Ashbourne course, i 2 st. each. Captain Armit was second on Field-Fare. On the same day, Mr. M'Donogh rode the celebrated Peter Simple for the Kilrue Cup, and this race is one of the most memorable to be found recorded in the "Calendar," so long associated with the name of; Hunter. It was a sweepstakes of 10 sovs. each, fo 100 added, for all horses carrying 12 st., 4 lbs. allowed to mares and geldings, four miles "over a sporting country," or what would now be considered a very ugly one. Mr. Preston was on his famous Brunette; Milo was ridden by Wynne, the immortal "Denny;" Blueskin did battle for Lord Waterford ; Captain Forrester was on Lady Longford, Mr. Rutherford on Paddy Whack; Mr. Preston had a second string to his bow in Morning Star; Mr. "Charlie" Lockwood piloted Teetotum; Mr. Peter Alley, of Ward Hunt renown, Post Boy. Mr. D'Arcy's Mischief and Mr. Davies' Regulator also ran. Mr. M'Donogh backed his mount for a "century," and took $£$ ioo to $£ 20$ that he would not be "headed" after jumping the first fence. Peter Simple, of course, went to front, and made the pace a "cracker," but before he reached the third obstacle, Denny Wynne shot past him on Milo, so the wager was lost. Many said if Mr. M'Donogh had not made that bet he would have won. As it was, Brunette did win, Milo was second, and Peter Simple third. In 1844, the subject of this memoir went to reside with Mr. Preston, at Bellinter. However, 
during that year he was remarkably lucky. He won the Westmeath Urn on Brunette, beating Tidings and Sam Slick.

On the 2oth March, at the Kildare Hunt meeting, he won the Ponsonby Bowl on Major Woodhouse's Kilfane, beating Paddy Whack and four others. A few days afterwards, he won the Kilrue Cup on Brunette, defeating Mr. Simpson's Albert, Mr. Alley's Desperate, Captain Burnett's Mameluke, Captain Watt's Eber, Captain Dyson's Gondorf, and Mr. Matt Dunne's Fanny Elssler. During the race, a heavy snow shower fell, and almost blinded the riders; near home Fanny Elssler ran against a post and fell. Mr. Dunne was riding her; and he often assured me that he would have beaten Brunette but for the mishap. Fanny Elssler won the Kilrue Cup in I 848 and $185^{\circ}$. In the month of April, Mr. M'Donogh, on Brunette, won the Foxhunter's Stakes, at the Ormond and King's County meeting; a few days afterwards a valuable stake at Limerick, beating Mathew (winner of the Grand National), Fencer, and Victor. In June, the Hurdle race (2nd class) at the Curragh, on Mr. Preston's Great Wonder, Lord Waterford's Firefly, and Mr. Ferguson's Fireaway, being his only opponents. At the Curragh October Meeting following, he "landed" the Corinthian on Fireaway. A week after that, when piloting Brunette for the New Melton Stakes atCahir, he got a severe fall and Blueskin won. Notwithstanding some injuries sustained, a few hours after the accident Mr. M'Donogh won a sweepstakes on Mr. Preston's Mountain Hare. During the following year he did wonders for Mr. Preston. He won for him the Hunt race at the Kilrue National Steeplechases, on 
Norma, a daughter of New Fashions, and on the same mare the Kell's Challenge Cup, defeating Mr. Alley's The Breeze, and Mr. Barnwall's De Freyne. At this time Brunette was in her "hey-day." She began the year well by winning the Kilrue Cup (for the third time in succession), beating ten good 'uns, including Mathew, St. Leger, Sam Slick, Fanny Elssler, and the Switcher. Soon after this she won the Foxhunter's Stakes at the Ormond Meeting, defeating Myrha (ridden by Sir George Douglas), Mathew, and Saucepan. Her next appearance on a race-course was at Mullingar, where she won the Westmeath Challenge Urn, value Ioo gs., with 40 sovs. added. Sam Slick was her only opponent. Then she easily defeated St. Leger for the Trim Gold Cup, and on that day week the wonderful daughter of Sir Herculeus ran third for a sweepstakes at Lucan. The "talent" looked upon the race as a certainty for her. All the runners except herself fell, and Mr. M'Donogh was walking in a wintier when, to his utter astonishment, the remounted Sam Slick shot past him and won. Mr. M'Donogh was not much to blame; as often occurs, it was a case of "caught napping." However, some of those who backed Brunette were greatly annoyed, made unpleasent remarks, and one of them went so far as to strike her rider. In the month of September, she won the New Melton Stakes, value 2 I 5 sovs., at Cahir, beating Regalia and Saucepan. A few days following Sam Slick (I 2st. 3lb.) beat her, carrying I 2st. 5lb., for the Rock Stakes at Cashel, after a severely contested race. The same day Mr. M'Donogh won the County Plate on The Disowned; but in the next race he did not fare so well, as he rode Mountain 
Hare, and when going at an up bank, an old woman ran across him and caused the horse to come down a "cropper." Two of Mr. M'Donogh's ribs were broken, and he was very severely shaken. Lord Waterford sent him to Cashel in his carriage, and two doctors attended him. To the astonishment of all who knew the nature of the injuries he had sustained, he won the Commissioners' Plate next day, for which Saucepan, Regalia, and Love-Letter ran, on Brunette. A filly of his, by Ilarkaway, from Coquino, won the second class of the Harriers' Stakes that year, and I believe he was part owner of Osprey, a filly by Birdcatcher, out of Emily, entered for all her engagements in Mr. Preston's name. She was second for the Angleseys, for which a baker's dozen competed, including Chanticleer (the favourite', Flirtaway, Lizzie (by Harkaway), and Erin-go-bragh. Bell came over from England and rode her. He thought he was winning easily, when Jacques came with a tremendous rush on Lord Howth's Mermaid, and "nailed" him on the post. Bell, knowing his mistake, was so sorry that he declined to accept any payment for the mount. Osprey ran for the Epsom Oaks, and two distances from home she looked so like winning that Mr. M'Donogh, thinking that it was "all over but the shouting," threw his hat on high; but, like some others, he lost his money and his chapeau, as she "cut it" at the finish, and Mendicant won. Twenty-four ran. Osprey performed very badly afterwards. Great as were the triumphs of Mr. M'Donogh and Brunette in $\mathrm{I} 845$, they were equally successful in 1846 , when he rode her for all her races, except when she finished third to 
Red Vixen and Fairy Queen, for the Mare's Plate, in September, at the Curragh. She won the Foxhunter's Stakes at Ormond, beating Mathew, Firefly, and Fireaway. She subsequently won the Kilrue Cup carrying I 2st. 7lb. ; St. Leger, 5 yrs. I 2st., was second; Mathew, aged, 1 ist. 81b., third ; Miss Tisdall, Blister; and Stoleaway, were beaten off.

Great was the astonishment of turfites when, soon after these performances, Saucepan, ridden by $\mathrm{Mr}$. William M'Donogh, beat her at Cashel. This was the mare's last race that year. In 1847 , she ran for the Liverpool Grand National, and Mr. M'Donogh accepted $f_{1} \mathrm{o}, 000$ to $f \mathrm{I}$ oo about her winning. She was as fit as the proverbial fiddle when leaving Worcester for Liverpool, and was conveyed there in a van, and arrived safely the Saturday before the race. Early next morning, the boy who had care of her came to Mr. M'Donogh and told him that she was amiss. He immediately went to see her, and noticed that she seemed to be hungry, starving in fact, and chewed hay and corn but could not swallow it, owing to an affection in the throat. He telegraphed to a very intimate friend of his to come to him at once. Consultation with his friend gave little satisfaction, as the busy tongue of rumour had driven the mare to 100 to I, and Mr. M'Donogh, like Sternes Starling, found he could not get out. About twelve o'clock the night before the Grand National, when $\mathrm{Mr}$. $M$ 'Donogh had been some time in bed, the servant came and told him that a gentleman wanted to see him on very important business; he was naturally opposed to having an interview with any one 
under the circumstances; but he consented, and was surprised to find that the visitor was his friend, Mr Dycer. He said, "Is it true Brunette has gone wrong? If so, I'll be ruined. I have $£^{2,000}$ on her, and to-night I bet another $f_{2}$, , oo that she 'd start." Mr. Dycer's feelings may be imagined when he heard the truth. However, Mr. M'Donogh consoled him to a certain extent, by assuring him that if he could not get off the bet, the mare would go to the post, even if it were necessary to carry her to it. Immediately after Mr. Dycer had left the room, another gentleman was announced; and, strange to say, it was the person with whom Mr. Dycer had the wager as to the mare running. He offered to give Mr. M'Donogh $\delta \mathrm{r}, 000$ if the mare did not start. I need scarcely say that the tempting offer was refused. On "the morning of the day," the mare blundered over a couple of small fences, and appeared to be unable either to gallop or jump. However, she started, and was a quarter of a mile behind when jumping the brook opposite to the stand. The spectators, who did not know or would not believe that there was something wrong with her, hissed and hooted. Warming to her work, she made up lost ground rapidly, actually jumped the last hurdle with the leader, and finished a good fourth to Mathew. She certainly would have won easily had she been fit. She was engaged in the Warwick Steeplechase run a fortnight afterwards. Mr. M'Donogh put $£$ I oo on her at 20 to $\mathrm{I}$. The ground was rather hard, one of the fences was a very nasty drop, and knowing that the mare was shaky on her "understandings," he was afraid of her breaking down. Consequently he asked a noble 
lord, who was one of the stewards, to have some tan put on the landing side of this fence. "Oh, no," he said, "you want to have the ground soft for your old crock." His Lordship had a horse in the race; he was backed for a "pile" of money; and at this very fence, first time round, he fell on landing, so that his Lordship, perhaps, by not saving the crock upset the pot. At this fence, second time round, Mr. Preston's mare broke down, and ended her racing career. She certainly was a "clinker." Mr. M'Donogh won nineteen races on her, including the Hunt Cup at Birr, Hunt Cup at Cahir, and Hunt Cup at Cashel, two years in succession. She won the Kilrue Cup four times in succession, ridden three times by $\mathrm{Mr}$. M'Donogh. Never did horse and rider understand each other better; their confidence was reciprocal; and long after the hand that pens these lines returns to the dust, "Allen" M'Donogh and Brunette will be remembered in Ireland, and stories related of their wonderful achievements. She was a dark brown, about 15-2 high, with great depth of girth, and powerful quarters, and was more remarkable for gameness and brilliant fencing than speed. She had a few foals; but, strange to say, none of them were good. Indeed, I think they never started, as they were tried and found wanting.

One of the most marvellous feats of horsemanship on record was performed by the subject of this biography, and occurred when he was riding Sailor for the principal race at Bandon, in the spring of 1835 . Ten started for it, including Monarch and Valentine, both great chasers. Sailor, when leading, fell at the fourth last fence, Mr. M'Donogh very narrowly escaped 
being killed by Monarch; however, he was up and in the saddle without much delay. In the struggle to get Sailor on his legs again, the head-stall of the bridle broke, and the bit, of course, dropped out of the horse's mouth; but his plucky pilot determined to go on. Mr. M'Donogh steered Sailor with gear as imperfect as that employed by our lamented Nestor, Admiral Rous, when he saved His Majesty's good ship, the "Pique." The first fence he met after the misadventure was a drop into a very narrow lane, with a small bank on the opposite side; fearing that the horse would bolt if he jumped him in to the lane, he turned the whip on him and sent him at it as fast as he could go. Sailor jumped from field to field; M'Donogh got him safely over the last fence, guiding him with his bridle in his left, and whip in right hand. The rider of Valentine, seeing the awkward predicament he was in, endeavoured to run him out at the last turn, but failed, and he won by four lengths, amidst a scene of the greatest enthusiasm. The great difficulty then was to pull him up. The first fence he met after passing the post was a four-footwall, which he jumped; the next was another wall still higher, which he also leaped; he then went into a field surrounded by a thick hedge, and after some time, the country people succeeded in stopping him. Never was a more cordial ovation accorded to a man than to Mr. M'Donogh that day; the cheering continued for a length of time, and the people hoisted him on their shoulders and carried him about the course. The following day he rode Sailor for a steeplechase. The horse fell going through a gap, and injured his head so severely that some of the brain was actually 
visible. He recovered; but for a long time after the occurrence he was almost mad. Heretofore, as he was a rather good-tempered animal, I believe, Mr. Elmore bought him for $£ 300$, and sold him soon afterwards for $f, 1, \infty 00$. Mr. M'Donogh, about this time, used to hunt a good deal in England; and though he seldom gave high prices for his horses, he was invariably wellmounted and well-known in the shires as being "a first flight" man in the days when the Marquis of Waterford, Sir David Baird, Lord Macdonald, Assheton Smith, Lords Clanricarde, Suffield, and Strathmore, Fred. Gardiner, Sir Francis Goodricke, Mr. Mostyn, Mr. Villiers, Mr. G. H. Moore, Captain Beecher, Lord Eglinton, Captain Lamb, Sir Frederick Johnstone, Mr. Powell, Mr. William M‘Donogh, Mr. Val. Maher, John Elmore, Billy Bean, Tom Olliver, and Jem Mason, were in their "palmiest days." It often occurred, when the sport was not very good with the hounds, to wind up with a steeplechase over the "Vale." One bad scenting-day, Mr. M'Donogh was riding Cigar, when, about six miles from Northampton, the Marquis of Waterford proposed to have a race, a sweepstakes of Io sovs. each, and ten entered. The country over which they ran was very big, distance five miles, and a church-steeple the winning-post. Cigar made all the running, jumped twenty-nine feet over a brook, and won. That evening, a distinguished circle of friends dined together in Northampton; and after dinner an incident occurred-one of many I could relate-which showed the good nature of our sportsman. When returning thanks, after his health had been drunk: he said, "Gentlemen, this is a very happy moment for me, but not so for poor Tom Olliver, as 
you are aware he was arrested to-day immediately after the race, and lodged in prison for debt. I propose that we raise a subscription, and satisfy his creditor." The hat went round, and about 300 sovs. were immediately subscribed. Mr. M‘Donogh was thereby enabled to pay the debt, and had the pleasure of handing a balance of 130 sovs. to the renowned " jock." This story reminds me of another, relative to Tom Olliver; a pleasing illustration of the fact that all true sportsmen are kind-hearted. The incident I am about to relate I take the liberty of copying from an old sporting periodical:

" Jem Mason, having received from Tom Olliver a private and confidential communication that he was not only in 'Short-street' but entertaining the sheriff of the county, and all he possessed between earth and sky was "Trust-me-not," who had been the cause of this financial pressure; he asked him to buy the horse of him, so that he might get rid of his unwelcome visitors. 'Don't you sell your horse,' was the reply, 'but send him to me and I will win you a race ;' and the advice was accompanied by a fiver for the railway fare. The added money brought the horse to Harlesden Green, where he was entered for a small steeplechase, for which Jem paid the stake. The horse came on the ground with a terrific bit, which, the instant the rider saw, he renoved, and substituted a double-rein snaffle, which Tom protested would never hold him. But he was told to mind his own business, and wait and see his horse win, which he did very cleverly; and Tom, in his delight and gratitude for having had a hundred put into his 'kick,' as he termed it, took an oath that he would fight for Jem up to his knees in blood! a 
recognition of value received which we do not often witness in this world. And so much did Jem appreciate the compliment that he rode and won for Tom several steeplechases afterwards, taking a tremendous jump with Trust-me-not at St. Albans, and breaking his leg on him at Derby, where he was ridden over, and confined so long to his bed that he could not ride Miss Mowbray in the Liverpool Steeplechase. But in Mr. Goodman he found an excellent substitute."

Mr. M'Donogh bought a little horse, called Perfection, when a two-year-old, for I 4 sovs; he was by Monarch, out of a Connemara pony. He thought very little about him, until one day the harriers were hunting near Willmont, and ran into the field where the horse was ploughing; he kicked himself free of the harness, and set off after the hounds. He jumped a wall about three feet high, and then cleared the deerpark wall, six feet six inches. The horsemen had to make a long detour to get into the park, and when they overhauled the pack, they found them about a mile and a half from where they got into the park; they had just killed their hare, and Perfection was with them. He was subsequently taken in, well cared for, and hunted for a season. Mr. William M'Donogh, alias "the Blazer," alias "Ould Muck," Allen's brother, one of the best steeplechase riders in the world, was stopping in Liverpool during the race-week, when one night the topic of conversation was relative to the performances of Irish horses over walls. The upshot was, that a well-known English sportsman bet IVilliam M'Donogh that he would not get a horse to jump six six-foot walls in fifteen minutes. He accomplished the feat on Perfection in seven minutes. 
A year after that, Mr. Allen M'Donogh lost a large sum of money at Aintree, and sold Perfection and two hunters to Goodman Levy. Soon afterwards, he won a steeplechase at Banbury on Cannon-Ball. Goodman Levy came to him after the race, and said: "I have that pony I bought from you entered in the next race, will you ride him for me?" He declined, saying, "Oh, he is only a slow hunter," but after some pressing, he consented, knowing he was a good fencer. Sixteen started, and he won by a field.

Apropos of "Goody" Levy, he was the man who had the management of the notorious Running Rein, and Lord George Bentinck traced the guilt of that nefarious transaction home to him. His Lordship, knowing that the horse's legs had been dyed, endeavoured to find the chemist where the "mixture"had been purchased. He suspected Levy to be connected with the attempted swindle; and when his Lordship went to Rossi's, to make inquiries, he ascertained that a large quantity of hair-dye had been sold a short time previously to a person, and, the proprietor added, "the gentleman ordered a second jar, and forgot to pay for it." "Oh!" immediately exclaimed Lord George, "I am sure of him now; it must be Levy;" and he brought Mr. Rossi with him to Tattersall's, where he knew Levy was; and the moment the chemist saw him, he identified him as being the purchaser of the dye. Levy was a passionate gambler. He had several racehorses at one time, and won many valuable stakes; but he died in poverty.

After Perfection won the race alluded to, Mr. M'Donogh met Lord Cardigan one day in the hunting-field ; his Lordship asked him would Perfection be a suitable 
hunter for him? He replied in the negative; but his Lordship gave a long price for him. The first day he hunted him he gave him three falls; he then gave him to his brother-officer, Mr. De Burgh. He bought Augustine from Captain Scott, of the 3rd Dragoon Guards, whose feats and horses were well-known then, as they are forgotten now, in this country, though the gallant Captain, arbiter-general in sporting matters in Australia, keeps their recollection bright there by his performances amongst the Melbourne turfites. With Augustine, Mr. M'Donogh was very unfortunate. He brought him with two others to La Marche, and he was so sanguine about winning the principal steeplechase there, that he refused 1,250 sovs. for him the morning of the race. He went to the course himself early in the forenoon, and told his groom to follow an hour afterwards with the horse. The servant did not know the way, some people misdirected him; and although the stewards were kind enough to wait an hour for him, he did not arrive till the race was over. On the following Sunday, Augustine started for a race at La Marche, and his owner put 500 sovs. on him. There was a very nasty brook, about seventeen feet wide, within the circuit, and he said to his jockey, Byrne: "Make the pace good, but steady him coming at this water-fence; if you go very fast at it, he's sure to fall." Byrne did the very reverse, and Augustine fell. Monsieur Delamere then purchased him for $\ell^{\mathrm{I}, 000}$, and ran him a few days afterwards for a steeplechase; Mr. M'Donogh again backed him for a large sum, and begged Monsieur Delamere to allow Byrne to ride him, but he refused, and put up Lamplogh. The horse bolted, and fell over the ropes; a 
few days after that he won a large stake, but his late owner hadn't a shilling on him. Mr. M'Donogh had a horse named Seaman, and when running in at Warwick, he bolted, lost fully a quarter of a mile, yet he won. Flyfisher, another of his, was a great horse; he sold him to Mr. Murray, the Manchester dealer, for $£ 600$, and he disposed of him to Mr. Powell for double the money. Just after Mr. $M$ 'Donogh parted with him, he ascertained that Lord Stamford would have given $£ \mathrm{I}, 000$ for him.

In $1850, \mathrm{Mr}$. M'Donogh went to reside at Athgarvan Lodge, the Curragh, as desirable a residence $\mathrm{a}^{\mathrm{s}}$ a sportsman could wish for. He kept a long string in training when there, and his Nom-de-guerre, Captain Williams, generally appeared in the list of subscribers to any important Irish race, and not unfrequently amongst the nominators for English Steeplechases. He was very unfortunate with his flat racers, and always had a greater liking for the illegitimate pastime than racing. His horses always went to the post very fit, sometimes rather over done. He compelled them to undergo a very severe preparation, and consequently many promising youngsters broke down under his severe discipline. He won a great many valuable cross-country events, and all his chasers were first-rate fencers. They were generally freely backed by the public, who were always sure of having an honest run for their money. M'Donogh used to import ten or a dozen yearlings annually from England; and his well-known figure was generally to be seen near Mr. Tattersall's rostrum during the St. Leger week, and his cheery voice was heard at many important yearling sales. He was, and is, a capital 
judge of horses, whether racers, chasers, hunters, or roadsters. He seldom gave a high price for a yearling. The most he ever gave was I75 guineas for Knightbridge, a colt by the Knight of Kars, out of BlackCotton, by Faugh-a-Ballagh. He bought Red Wine, when a foal, for $£$ roo, and he was decidedly the best two-year-old of his year in Ireland, and won the Nursery Stakes, Waterford Testimonials, the Kirwarlins, and Ballymanus Stakes, and ran second to Dora for the Angleseys. He was a moderate threeyear-old. Another good horse he got for small money was Switch, for $£ 75$; Cameo, by Cannobie, out of Camiola, by Windhound, he bought for $£ 15$; his hocks were so blemished that he appeared to be incurable. Shortly after he got him he rode him across

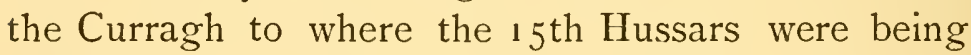
drilled. Several of the officers "chaffed" him about his mount, and one asked if he thought him a fit one to come and inspect them on. "He beats anything in the Regiment for a mile," was the reply. "How long will you give us to consider it?" "Until this evening; and I'll bet you a crown you don't come and make the match, and a tenner that I win if you do." The match came off next day, and Cameo won in a canter. His owner then put him into training, and he won several valuable stakes. In $\mathbf{1 8 6 4}$, he ran for the National Hunt Race at Punchestown, and was backed for a great deal of money; soon after starting he was cannoned against by another horse; both fell, and Mr. Exshaw, who rode the son of Cannobie in the hurry and excitement jumped on to the other horse, and did not discover his mistake until it was too late to catch Cameo. One of the finest races ever seen in Punches- 
town took place on the next day for the Downshire Cup; eight started, and there was a grand "set to" between Captain Ricardo on Cameo, Mr. George Knox on Lottery, and Mr. Valentine on Mont-pelier. Cameo won by a head, and Lottery beat Mr. M'Grane's horse by a similar distance for second honours.

Mr. M'Donogh got Blush Rose in exchange for a worthless hack. She was a speedy mare, and won several races. He appears to have possessed a happy knack of imparting to his pupils that perfect style of horsemanship for which he himself was proverbial. Some of the best steeplechase riders of the age graduated under him, including Captain Ricardo, Captain Pritchard Raynor, Mr. T. Beasley, Paddy Gavin, and George Gray. Captain Pritchard Raynor, late $5^{\text {th }}$ Dragoon Guards, was a fine horseman, and won several steeplechases, including a few for his preceptor, and, moreover, distinguished himself highly on two celebrities bearing tiie name of Blondin, as he rode one while walking on the tight rope across the Alhambra, and the other successfully round Punchestown and other courses. Mr. M'Donogh purchased Spanish Lord when a yearling, at Lord Stamford's sale, for 20 guineas. When a four-year-old he won the Irish Grand Military at Punchestown, ridden by Cap. tain Pritchard (as he was then called). Mr. M`Donogh trained him for that race. His stable-companion, the fashionably-bred Garde Civique, won the Conyngham Cup next day. Captain H. M'Calmont rode him, and he was not backed for a shilling by his owner, who had his money on another of his horses, Ajax. Mr. $\mathrm{M}$ 'Donogh was second for this race the previous year, with one of the best chasers that ever carried the "yellow and ruby," Glenavon, a four-year-old. Mr. 
Garrett Moore rode him, and he was beaten cleverly by Chasseur, a horse the property of the late Colonel Ainslie. A very long price was refused for Glenavon after the race, $£ 600$, I think. He broke down, and never ran again. The worthy sportsman under notice astonished some of the youngsters by the style in which he rode Fairymount, a horse of his own, by Warlike, for the "Downshire," in Punchestown, in 1867. When he walked out of the dressing-room in a "bran" new jacket, and with a pair of white kid gloves on (he always wore kid gloves when riding a steeplechase), some junior sportsmen were joking with him, and I well remember the hearty cheer accorded to him when, putting his hand on Fairymount's wither, he said: "Some of you, youngsters, can't do this, though ;" and he immediately vaulted into the saddle (not a bad performance for a man in his fifty-ninth year). He was fifth in a field of thirty. Fairymount was engaged in the Conyngham Cup, run next day. His owner thought it useless to start him, but yielding to the earnest solicitation of Paddy Gavin, he did so. He had much difficulty in getting a man to ride him : at length, he secured the services of Captain Hutton. Twenty ran, and 25 to I was laid against Fairymount; he won easily. For 95 sovs. Mr. M'Donogh purchased Mr. Saville's speedy miler, Uhlan, late Blueskin. He put him to the jumping business, and ran him for the Grand Stand Plate at Cork May meeting, 187 I. He backed him to win $£ 4,000$, and he started first favourite in a field of twenty-nine runners. He was defeated, after a most exciting finish, by an English mare, Captain Barker's Aurifera. Jones just got her home in front by a length. Many 
censured Mr. T. Beasley for the manner in which he rode Uhlan, and said that he should have won. We seldom see an old head on young shoulders; he had not much experience then. The course is a circular one, and it is very difficult to steer clear in where there are so many in the fray; and I think it must have been apparent to every one who saw the race, that several were watching Uhlan, and that he was shut-out more than once. He bungled over the last hurdle too; and I coincide with many good judges I have heard state, that no man could have altered the result of that race.

The last time that Mr. M'Donogh sported silk was at Punchestown, 1872. He rode for a sweepstakes of 25 sovs. each, owners up, two miles and a half, 14st. each. The result of the race was:-Mr. Sadlier's Bismarck, carried Iolb. over, Ist ; Mr. Linde's Neria, 2nd; and Mr. M'Donogh's Humming Bird, 3rd. For some years past he had had no horses in training, and he seldom goes to a race-meeting, though he sometimes backs his fancy. He is a thorough sportsman. Nil desperandum appears to be his motto. He was a good game-shot, and a devoted Waltonian, and he could "whip" a stream in artistic style. I could relate many incidents of remarkable feats accomiplished by him with the gun and the fly-rod. I will just mention a couple. Many years ago when shooting on the mountains, near Cashel, two deer, a buck and doe, crossed his path, when his gun was charged with snipe-shot. They were close together when he fired; the doe fell dead on the spot, and the other was found dead a mile further on. That reminds me of a story he told me about a pointer of his which he had with him 
that day. His performance was, to say the least of it, a striking instance of canine sagacity. The grouse were very wild, and he could not get within range at all. After some hours of fruitless labour after them, he noticed that the dog went a long distance before him, made a wide detour, and drove the birds back to him, and in this way he got several brace.

$\mathrm{He}$ was fishing in Connemara for trout one day and rose a fine salmon. He missed him, and tried every fly he had without getting a second chance. Having killed about a dozen and a half of good trout, he repaired to his lodgings, and tied a fly, with which he returned to try conclusions with the salmon. The first cast he made, he hooked him, and after playing him for three-quarters of an hour with light tackle, a trout-rod, and without net or gaff, he killed a fish weighing $24 \mathrm{lbs}$.

In 1872, Mr. M'Donogh left Athgarvan Lodge, and for some years past he has resided in Dublin. He always has a few hunters; and may frequently be seen riding through town, or in the Phœnix Park, or driving his well-appointed trap and high-stepper, and sometimes enjoying a day's fox-hunting in Meath and Kildare. $\mathrm{He}$ is a veritable "ever-green ;" and it would appear that many happy days are yet in store for him to enjoy the manly sports he loved so well:

“On eagle's wings immortal scandals fly, While virtuous actions are but born and die."

But he, during a long and eventful career, has preserved a reputation unblemished, a high character, and a good name. All who know him, his biographer included, hope that he may "prosper in his ways," and that happiness may gild the last years of the life of this "fine old Irish sportsman." 


\section{OUR IRISH JOCKEYS AND RACING OFFICIALS.}

$\mathrm{OH}$ ! gentlemen, I'm much surprised you ask of me to sing, You know my voice, and so you know 'tis really " not the thing ;" But if you choose, I'll not refuse to do the best I can,

And what more can I do, my friends, "or any other man?"

Chorus-So push around the wine, my boys, and fill your glasses bright,

And here's the toast, "The Irish Turf," our only toast to-night.

I know you are good sportsmen all, and " racy of the soil," And most of you I've often met at Cork Park and Baldoyle : You must be the right sort, my boys, and consequently then, I'll sing a song as best I can about our Irish " racing men."

So push around the wine, \&c.

Each year I have some leisure time, and though but for a while, I see full many a race fought out in our beloved Green Isle; Such being the case, I guess, my friends, I know a thing or two, So, of our Irish riders bold, "a tip" I'll give to you.

So push around the wine, \&c.

"Comparisons are odious," lads, but all of you, I'm sure, Will say the best of amateurs is surely "Garry Moore ;" The many glorious victories he's gained on old Scots Grey Are quite enough to prove him still the best man of the day. So push around the wine, \&c.

A second amateur there is, and second but to him,

An honourable gentleman, some people style "the Limb," * Whom all of us soon hope to see, uninjured by his fall, All right again to score a win for "dear old Jockey Hall." So push around the wine, \&c.

And I'm sure, my friends, you all will say, 'tis only just and right To fill a flowing-bumper cup in honour of "Joe Whyte;" So here's to him with three-times-three, and may he soon recover, And never be "sold" again, as on that "Golden Plover." So push around the wine, \&c.

Another true and tried there is, who knows no trick or dodge, Accomplished Tommy Beasley, with his luck of Eyrefield Lodge; Another too, " a warrior bold," $\dagger$ is worthy of my song, And worthier, since he's mated to the "lovely Armstrong."

So push around the wine, \&c.

* Captain the Hon. Greville Nugent.

+ Mr. Keville Davies, I 7 th Lancers, who married a daughter of Mr. Sergeant Armstrong. 
And Murphy, Russell, "Oldham,"* too, I'll give them all their due,

If mounted fair, they all ride straight, and pluckily, and true;

And "Appleton," a " turfite" staunch-may the blue and silver lace

Be often seen, as oft it was, the foremost in the race!

So push around the wine, \&c.

And now about professionals a few words I shall say-

Of all of them I cannot sing, for "time brooks small delay ;"

But, first, here's to the amateurs, to one and all, hurrah!

And first amongst the "leading lot," Bob Exshaw of Hybla.

So push around the wine, \&c.

If ever you've a good 'un, sir, and want a tip-top man,

Young Canavan should catch your eye, secure him if you can;

At Baldoyle, in September, a grand treat there was seen,

When pluck and patience gained the day on Rattle(ing) Tambourine.

So push around the wine, \&c.

The Ryans are perfection, and Bob Murphy seldom fails,

Indeed it truly is a treat their finish " up the rails ;"

And you may search the Green Isle through, from Galway to the Lee,

And Gavin's like for pluck and skill you seldom, boys, shall see.

So push around the wine, \&c.

Tom Miller, too, we can't pass by, for where's the better boy?

Or Stephen Fleming of Rossmore, who steers for Captain Joy;

Or Wynne, Tom Kelly, Broderick, and others I might name,

With the gallant few I've sung to you, who're not unknown to fame.

So push around the wine, \&c.

Now if you go to any meet (well managed) there you'll see Tom Waters-" Rushing Waters"- the eminent C. E. ;

So here's to him-with glasses filled-long life and wealth galore! And grant that we, with him, may see full many a race-meet more. So push around the wine, \&c.

And here's to Hunter-Robert J.-'tis every " turfite's" prayer, May the keeper of the "Match-Book," boys, long fill the judge's chair :

A handicapper true and tried he proved himself to be, Thanks to his skill, "a finish rare" full often may we see.

So push around the wine, \&c.

* Mr. Hubert Davies.

$\dagger \mathrm{Mr}$, J. Hutchinson. 
A handicapper do you seek? you may search both near and far, Nor find a better in the land than Villie R. Dunbar.

But, gentlemen, your temper's tried, yet one more toast, I prayThe Irish Sportsman and ourselves, here's to both, hurrah!

fune $1 \mathrm{gth}, 1875$.

\section{MR. JOSEPH DELAMERE WHYTE.}

I'M not " the Poet Laureate," but I sometimes make a "rhyme ;" I don't often try to do so-'tis seldom I have time;

Yet just norv I am at leisure, and a few lines I'll indite, And try to sing the praises of my hero, $J$. D. Whyte!

Of course you've often heard of him-if not 'tis very plain You've never been to Newbridge, to Naas town, or to Clane; For round about that country, wherever you niay go, All classes "hymn the praises" of my "plucky little Joe"

Now, if e'er you have "good 'un" give "MIr. Joe" the mount, I'll give you his address - 'tis Clane, his residence Viewmount. Of names he has full many-" Walter," "Dominick," and so You easily can hail him, but he answers best to "Joe."

You've heard of "Irish victories" beyond the "Irish wave," Of the "doings" of P. Gavin at Croydon on Clonave;

He's a first-rate plucky horseman, doing ever "what is right," But I think he ne'er could "give an ounce" to our good friend Joe Whyte.

For he's one of our best riders, deny it if you can,

For, search the island through and through, where is the better man?

Why speak we of his victories at Galway or Baldoyle,

Or laud "an Irish gentleman" so "racy of the soil?"

When first he won in Punchestown--sure I was there to seeHe rode the Farmers' Race upon a horse called N.M.D. ;

A most exciting contest with Rosewood and Malone,

But Joseph rode in brilliant style, and landed "the old roan!"

When riding then at Limerick he got a nasty fall,

Where Alice, in the Tradesman's, was knocked o'er at the wail ;

Then the Garrycastle Handicap he won down at Athlone, Where he also won the Challenge Cup on Red-tape for Malone. 
When first he "gained celebrity" and "got world-wide renown," "Twas when he won the Downshire on Tom Thumb at Punchestown ;

Then "the sporting scribes" all called him "the lucky Mr. Whyte,"

And good judges praised his horsemanship, as was both just and right.

In "sixty-eight," I think it was, folks came from near and far To see the great Cup Race-'twas 'twixt Olympia and Polestar; He donned the "black and vertical," rode pluckily and rare, Was only beaten by a length by Harper's little mare.

But of all the races that our friend Joe Delamere has ridden The best was for the Conyngham, on the game-like little Kitten; For four miles he made the running, escaping falls and knocks, But, alas! "got done" just on the post by Harford on Wild Fox.

You've often heard of Fairyland, Gamekeeper's greatest son;

You've heard, too, that at Cork Park the Grand Stand Plate he won ;

Within the bounds of "fair Kildare," though he search each hill and plain,

Joe Whyte can never hope to find so good a horse again.

Old Polestar-you remember-the lovely little blackHe won at least twelve races with Joe upon his back; He was indeed a rare bred one (Alma Legatee) -

Three cheers for Moffat's little horse! his like we ne'er may see.

1 landed a "cool hundred" last May, my friends, and more,

When Joe won the Kilmoylan Stakes down south at Curraghmore; Like a kind friend he gave "the tip" to "plunge on Lady Spencer"-

"I know the course is ugly, but the mare's a perfect fencer."

When he won the Dublin Plate, in August, at Baldoyle,

He charmed each sportsman true and tried who stood on Irish soil ;

For J. D. White's known everywhere-north, south, and east, and west-

Respected by the rich is he, and by the poor he's bless'd.

The Viewmount stalls held many a crack-Ah! who could name them all!

A gile and Comet, Fairyland, and Nicholas Mulhall;

The Kitten, too, and N. MI. D., and others I could tell,

With Heller, of the Juggler blood (please note the recent sell). 
So here's to Ireland's second jock (for Garret Moore is there, And he is most undoubtedly our greatest amateur);

But Joe is a "good second"-no "jealousy can brew" Dissension 'twixt Perfection One-Perfection Number Two.

So here's to Joseph Delamere! more luck and length of life! And luck and life e'en brighter to his fair and dauntless wife! So fill your glasses all again. Success to both! Hurrah! The "pluckiness" of Viewmount and the "sweetness of Hybla! * 9th January, 1875.

\section{PUNCHESTOWN, 1877 .}

FIRST DAY.

Covie, rouse from your slumbers

And join in the numbers

That are bowling along to the plains of Kildare ;

Youth, beauty, and fashion,

In carriages dash on,

While fun and good humour are seen everywhere.

Safe in through the gap,

Without a mishap,

The ladies smiles rival the beams of the sun ;

Who would care for the prize,

Unless their bright eyes

Were twinkling with joy to enliven the fun.

Great Marib'rough of old,

As in hist'ry we're told,

A bove all his peers shone supreme and resplendent,

While in peacefuller ways,

They deserve equal praise,

His fame is upheld by his worthy descendant.

His Duchess, God bless her,

May fortune caress her,

Keeps bowing to all with a matronly smile ;

Her fair blooming daughters,

Like Nymphs of the waters,

Are winning all hearts in the Emerald Isle.

Who is that in the "Ulster,"

Did he come up from Munster,

To gaze upon Leinster and make "puns" upon it ?

But no, that's no Dandy,

That small man so handy,

Owns a soldier's brave heart,'tis the Young Duke of Connaught.

* The above eulogy appeared originally in the Irish Sportsman, as did our "Irish Jockeys," but under my " nom de plume alone. 
Dear old Punchestown

We give you the crown,

And place the "bays" freely on Drogheda's brow;

May the black silver lace

Ever hold foremost place,

It was he made it famous, we all must allow.

The first bell is ringing,

The stable-boys bringing

Each horse to the paddock to strip for the race.

They have finished the "canter,"

Come stop all this banter,

The business commences when Long takes his place.

With the red flag advancing,

While horses are prancing,

His fame as a starter let others relate;

At the word " go," eleven,

Like meteors from heaven,

Are sent on their way for the Bishops Court Plate.

Then the Bee and Lightfoot

Lead the way through the dirt,

While others are getting quite thick in the "chanter ;"

Tom Beasley on Ned

Gives the five-year-old head,

When he lands on the flat, so he wins in a canter.

For the Drogheda Stake

A dozen now take

Their places; they're off, now the contests begin ;

See, there goes Lord Tara,

Like famed "Pat O'Hara;"

'Tis Beasley himself that again scored a win.

The Irish grand military

Never were dilatory

In producing good horses and men too to ride

With Thunderbolt's son

The battle is won

By Mr. Lee Barber, who hails it with pride.

The "piece de resistance!"

Come give me assistance,

Fair muse of my pen till I give each his due;

For never together,

In pig-skin or leather,

Were nineteen men braver e'er brought into view. 
There's Foreman, Provider,

Lady Fanny beside her-

That swect little mare that they call Cutty Sark-

Bushranger, and Badger,

His owner's no dodger-

Long life to his Lordship, I here may remark.

There's Island Harp, Parvenu,

Fairy Queen, Birdie too,

With the Inny, whose jock has a smile on his face,

Of sweet satisfaction,

As if from distraction,

He'd kicked the Attorney clean out of the place.

There's Tempest and Martinet,

Island Harp we can't forget,

Lord Waterford, likewise Young Nick of the Woods.

Agitator, Breechloader,

My Muse, I shan't goad her,

We'll finish with Vengence, a rare bit of goods.

They are quickly despatched,

Seeming equally matched,

Some are down at the double, and some at the wall.

Foreman, Parvenu,

Island Harp, Vengeance, too,

Are leading the van here, but waiting the call.

Island Harp soon gives way,

The others make play,

Vengeance most dangerous looking withal ;

Mr. J. Beasley

Wins on him easily,

Fulfilling the hopes entertained by the "hall."

Eleven are up

For the Kildare Hunt Cup,

Mr. Crosby's Macmahon some few lucky men back;

The favourite, Grey Plover,

Like many a lover,

Won't come to the point, so he is beat like a hack.

\section{SECOND DAY.}

After happily napping,

To hear the rain tapping

'Gainst the window, is dismal to those who'd sport silk.

Though the sun be not shining

It is useless repining,

Or grumbling; you know there's no help for spilt milk. 
The ball is set going,

The farmers look knowing,

See young Paddy Gavin among them is up;

But Pat gets a "spiller,"

Heath Hen and T. Miller

In the commonest canter walk off with the Cup.

The Grand Military Hunters

Will find out the grunters;

The imposts are heavy, the pace is a "clipper;"

But Mister Hartigan

Has the heart of a man.

May be long wear the laurels he won with the "Skipper."

There is one more than eight

For the Prince of Wales' Plate,

What is wanting in numbers they have it in form.

Nine to two against Thirsk ;

Four to one will we risk

'Gainst the Admiral - see how the bookmakers swarm.

La Fornarina is out,

And the favourite. That shout

Comes from layers of odds-the race lies with four.

Rock Savage, Sweet Meadow,

Are passed like a shadow,

By Toole, as he cleverly lands Rassanmore.

For the Downshire Plate

The excitement is great,

Russell's Appleton starts with the best of the "call :"

Sagacity's buff

Shows he had quite enough,

So sagacious enough, faith, he falls at the wall.

We spoke of Grey Plover

As a too bashful lover,

But Blacker now owns him and T. Beasley rides.

What a beautiful tussle

Between him and Russell.

Here's a health to his owner, and likewise the bride's.

With the number thirteen,

For the Railway Plate, seen,

Country Lass was picked out with R. Murphy to ride her;

But the mare failed to stay,

So here let me say

May Punchestown always of mirth be Provider. 


\section{L'ENVOI.}

I PART from these pages with a regret not unlike that engendered by the separation of old friends.

To say farewell is always a pain, but especially when we say the sweet, sad word to those of our own kin ; and surely one's writings must be numbered amongst it. Some things there are, however, connected with the publication of these sketches, which make the completion of my task not quite unpleasant. When, months ago, I took it in hand, I had calculated on little outer aid; but a thousand marks of undeserved sympathy and support from not only old acquaintances, but from many with whom I had had hitherto no connection, opened up to me a quite undreamed-of vista of generous and sportsmanlike co-operation. I take this genial Christmas-time to thank them with all sincerity, and in the sure belief that the kindness which animated them in the past, will make them indulgent to the many shortcomings which, I have no doubt, will be found in this, my first book. Vale.

B. N. F. 
$\int_{10}^{2}$

31.

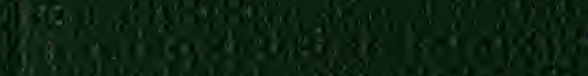

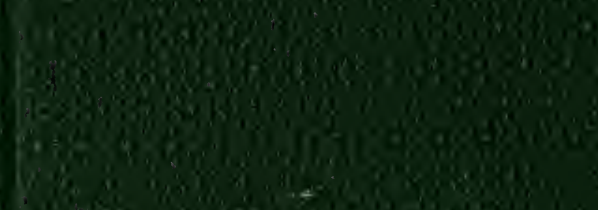

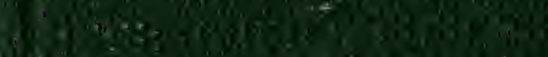

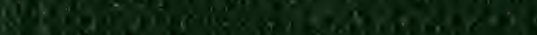

6h8 8 .

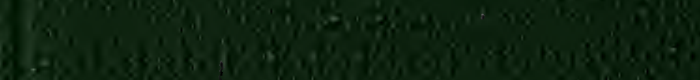

$\operatorname{sen} 20 \sin 28 \pi$

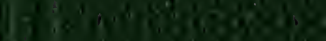

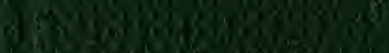

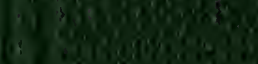

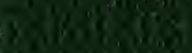

a.

3.

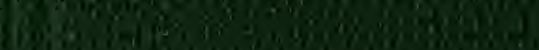

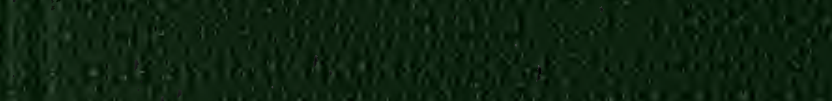

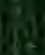

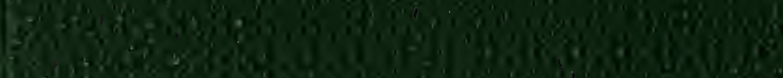

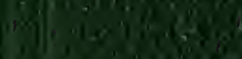

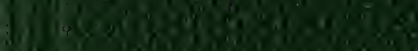

19

$\sqrt{10}$

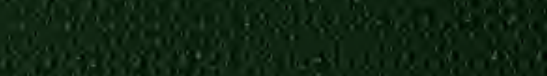

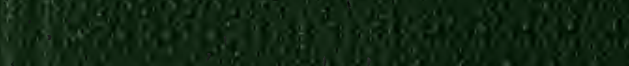

d.t.

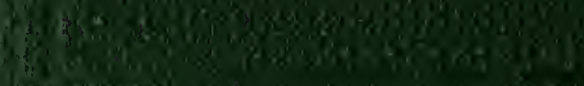

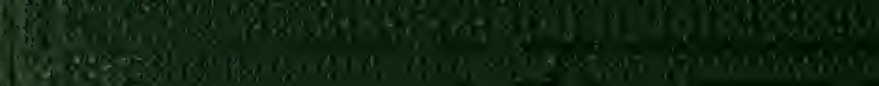

